Historic, Archive Document

Do not assume content reflects current scientific knowledge, policies, or practices. 



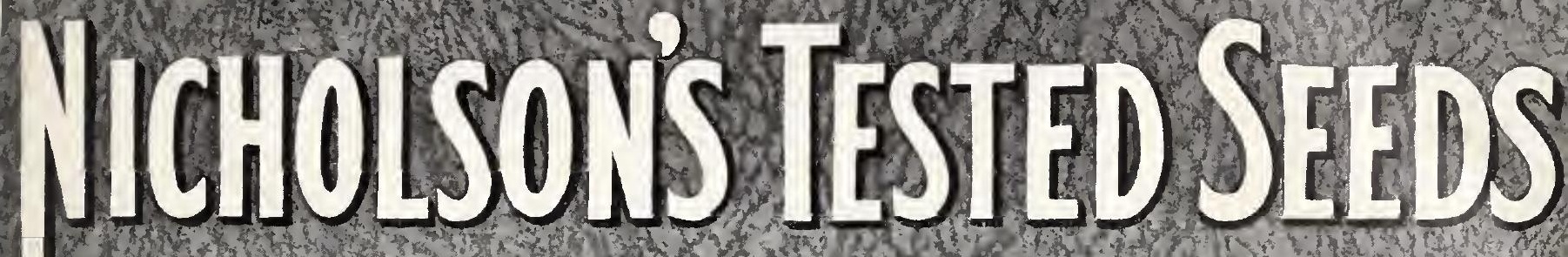
I fO 5 DUTHERU PLAWUERS

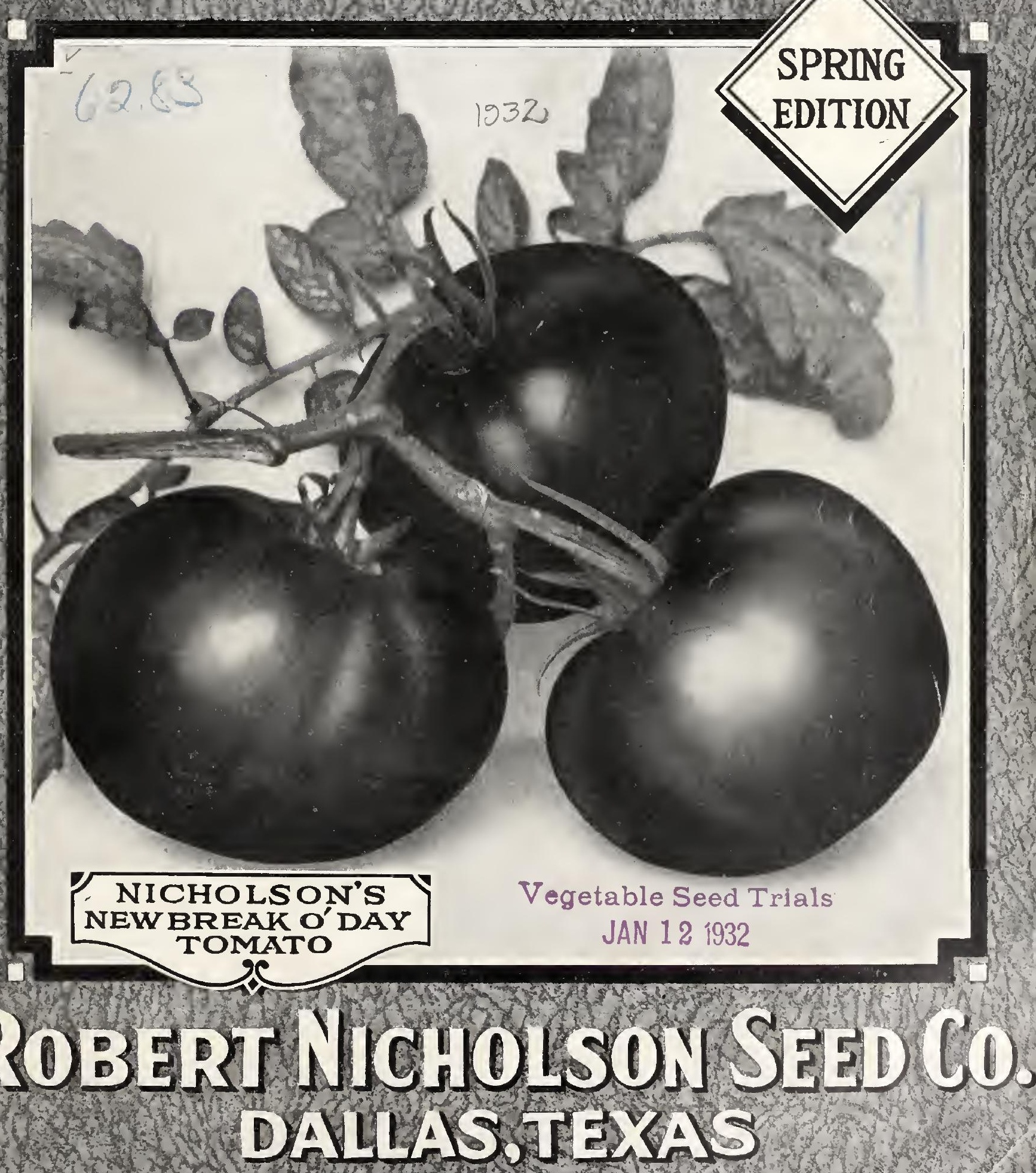




\section{To Our Customers}

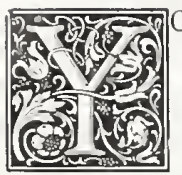

U, as a customer, contribute to the success of any firm with which you deal. Therefore, please allow us to thank you for the orders you have sent us in the past, and to assure you that we are anxious to serve you in the future. Most illustrations and many descriptions presented to you in this catalog are new; it is worded in simple, everyday language, and compiled in such a manner that makes it readily understood. For almost half a century we have been serving the Southeln planters during times of depression as well as prosperity, caring for the wants of the smallest seed buyers as well as the largest, and at all times keeping an ever watchful eye on quality.

Seed production is an art; the beauty of a flower or the quality of a vegetable is not an accident, and it is therefore necessary that we contract for the growing of Nicholson's Tested Seeds in all four corners of the earth, as no single locality affords a sufficient range of climatic requirements to grow all kinds of seeds; this brings us face to face with the fact that it requires many years of successful operation and gathering knowledge to be able to know the proper areas for the growing of the hundreds of varieties that we handle. You will find Nicholson's Tested Seeds on sale at your favorite store-if they handle the best. Should your merchant be unable to supply you, send your orders to us and they will be filled without delay.

\section{PLEASE READ THIS BEFORE ORDERING}

Kindly Read Carefully the Few Suggestions Below, Which, if Followed, will Help Us to Fill Your Order Promptly.

HOW TO ORDER. Please be careful to sign your name, post office, rural route, State, on every order. Be sure to give your nearest express office, or if you desire seed forwarded by freight your nearest railroad station. Write plainly.

TERMS, Cash with order. Customers will please remit by post office or express orders, checks on Dallas or New York Exchange. To insure you against your own loss we kindly ask that you adopt one of the methods above in making your remittance as we deem it unsafe to send loose currency and silver in an envelope with an order.

STAMPS. On orders of seeds where the amount is less than $50 \mathrm{c}$, we will accept stamps in good condition (one- and two-cent stamps preferred) the same as cash, but we ask that stamps be wrapped in oiled paper, to prevent sticking together or to the order.

ORDER EARLY. It will greatly facilitate shipments if orders are sent in early. We endeavor to ship out all orders day received, but sometimes it is impossible during the rush season.

NON-WARRANTY. We send out seed that will, to the best of our belief, give entire satisfaction. Seeds of the best quality sometimes fail through impioper treatment, shallow, or in too dry soil. For these reasons Robert Nicholson Seed
Co. gives no warranty, expressed or implied, as to description, purity, Co. gives no warranty, expressed or implied, as to description, purity,
productiveness or any other matter, of any seeds we may send out, and we will not in any way be responsible for the crop.
NO GOODS SENT C. O. D. No goods will be sent by us C. O. D., as it requires about twice as much time to handle a C. O. D. shipment and it also entails an extra expense for collection charges that our customers would have to pay.

HOW TO FIGURE POSTAGE RATES. We pay the postage on all seeds listed in our catalog in packets, ounces, quarter pounds and pounds. Where larger quantities are ordered the customer pays the transportation charges, and orders are usually sent by express or freight, you paying the charges on receipt of goods. However, for the benefit of our customers, especially those living on rural routes, who would rather have their order sent by mail, we have prepared the following rules for computing postal rates:

\section{Parcel Post Rates}

Limit of weight on parcels is $80 \mathrm{lbs}$, to all zones.

If you do not know which zone rate applies, consult your Postmaster. FOR ZONES 1 AND 2-One pound is $7 \mathrm{c}$. Add $1 \mathrm{c}$ per pound to $7 \mathrm{c}$ for each additional pound weight or fractional pound of the package. Thus 7 pounds will be $7 \mathrm{e}$ plus 6 additional pounds at $1 \mathrm{c}$ per pound or

ZONE 3-One pound is $8 \mathrm{c}$. For each additional pound add $2 \mathrm{c}$. ZONE 4-One pound is $8 \mathrm{c}$. For each additional pound add 4c.

ZONE 5-One pound is $9 \mathrm{c}$. For each additional pound add 6c.

I N D E X

Abronia

Ageratum

Alfalfa

Alyssum

Amaranthus

Antirrhinum

Aquilegia

Arctotis

Argemone

Asparagus

Asters

Baby's Breath

Balsam

Balsam Apple

Balsam Pear

Barley

Beans, Garden

Beans, Field

Beets, Garden

Beets, Stock

Bird Supplies

Books, Bird

Books, Garden

Broceoli

Broom Corn

Brussels Sprout

Bulbs and Roots

Burning Bush

Cabbage

Caladium

Calendula

Calliopsis

Canary Bird Vine

Candy tuft

Cane

Cannas ...........

Cardinal Climber

Carnations

Carrots

Castor Bean
Cauliflower

Celery

Celosia

Cherianthus

Chrysanthemum

Clarkia

Clover

Cockscomb

Coleus

Collards

Columbine

Coreopsis

Corn, Field

Corn, Pop

Corn, Sweet

Cosmos

Cotton

Cypress Vine

Dahlias

Daisies

Darso

Delphinium

Didiscus

Dog Supplies

Eggplant

Endive

Eschscholtzia

Eupatorium

Everlastings

Fertilizer

Fieterita

Fish Supplies

Flower Seeds

Four O'Clock

Foxglove
Gaillardia

Geranium

Geum

Gilliflowe

Grass, Lawn

Grasses, Field.

Gourds

Grohoma

Gypsophila

Hegari

Herbs

Hibiscus

Hollyhocks

Horseradish

Hotkaps

Humulus
Ice Plant

Insecticides and Fungi-

cides

Iris Back Bean

Kaffir

Kale

Kochia

Kohl-rabi

Lantana

Larkspur

Leek

Lettuce

Lily

Linium

Lapine

39, 53 Mangels

$\begin{array}{ll}38, & 59 \\ & \end{array}$

Marvel of Peru

Matricaria

Mexican Love Vine

Mignonette
Millet

Milo Maize

Misc. Supplies

Moon Vine

Morning Glory

Mourning Bride

Muskmelon

Mustard

Nasturtiums

Nigella

Nitragin

Oats

Okra

Onion

Painted Tongue

Pansies

Parsley

Parsnips

Peanuts

Peas, Field

Peas, Garde

Penstemon

Peppers

Perennial Pea

Periwinkle

Petunias

Phlox

Planting Schedule

Poppies

Portulaca

Potatoes

Poultry Supplies

Pumpkins

Radish

Rape

Rhubarb

Ricinus

Rose Bushes

Rose Moss

Rye
Salpiglossis ……..............12 Salsify

Salvia

$+\ldots . .12$

Scarlet Runner Bean......16

Scarlet Sage Bean 12

Sea Lavender

Seed Disinfectants

Seeders

Shallu

Sesbania

Snapdragon

Solanum

Sprayers and Dusters

Squash .................... 64,65

Squash

Stocks

Sunflower

Sweet Peas

Sweet Potato

Sweet William

Sweet Wivelsfield

Swiss Chard

Texas Blue Bonnet

Thalictrum

Thumbegia

Tomatoes

Torenia

Tuberose

Turnips

Verbenas

Vetch

Vinca

Vines

Viola

Wallflower

Watermelon

Wheat

Zinnias 66 67 43 12 49 49
14
. .38 13 .

.
8

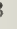
. 


\section{Nicholson's Quality Flower Seeds}

There is nothing that adds more to the beauty of a home than flowers-in fact, a "house" is not a "home" until it is planted. The soil best adapted to flowers generally is a light loam containing a sufficient amount of sand to make it porous. Blooms are generally larger and more beautiful when produced on plants of vigorous growth, hence a portion of the garden should be prepared by deep spadings, thorough pulverization and liberal enriching with plenty of well-rotted manure. For enrichment, we recommend Nicholson's Pulverized and Sterilized Sheep Manure, which is free from weed seeds.

IMPORTANT-PLEASE READ: Most flower seeds are very small in size. If covered too deep when planting, the seed will not come up. This is the cause of many failures. A good rule to follow is to never cover the small seeds more than three to four times the thickncss of the seed. Plant in rows and press the soil firmly over the seed. The young plants should be thinned out so as to prevent crowding. Never plant small flower seeds when the ground is wet.

\section{Abronia}

1732-UMBELLATUM ROSEA. This pretty plant is also known as Sand Verbena. It is a very rapid growing trailing annual which is excellent for growing in baskets, rock gardens or open border. The trailing stems will often reach a length of 3 to 5 feet. They throw up numerous rosy lilac flowers all through the summer and fall. The plants are very much like Verbena and are very fragrant, especially toward evening. Plant in early spring. Pkt., 15c; 2 pkts., 25c.

\section{Amaranthus}

These plants give brilliant contrasts of color, being useful for tall borders, groups and foliage effects.

1404-TRICOLOR (Joseph's Coat). Leaves variegated red, yellow and green. Pkt., 10c; 3 pkts., 25c; oz., 50c, postpaid.

1405-MIXED. Many varieties and colors, Pkt., 10c; 3 pkts., 25c; 0z., 50c, postpaid.

\section{Sweet Alyssum}

I402-MARITIMUM. A hardy annual used for borders and edging, comes early in the spring, covering itself with clusters of pure white flowers. Usually grows about 8 inches high and spreads. Pkt., 10c; 3 pkts., 25c; $0 z ., 50 \mathrm{c}$, postpaid.

I403-LITTLE GEM (Carpet of Snow). A beautiful white sort for borders. Plants grow about 6 inches tall, produce an abundance of flowers. Pkt., 10c; 3 pkts., 25c; 0z., 75c. post paid.

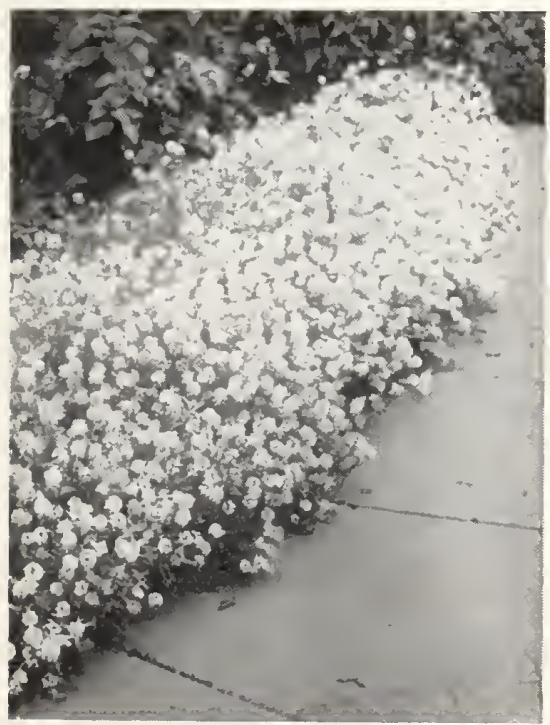

1403-Sweet Alyssum

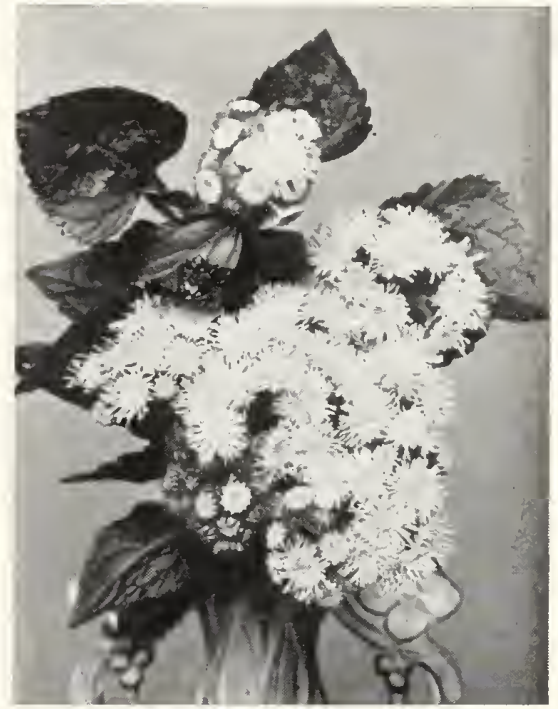

1401-Ageratum

\section{Ageratum}

A hardy annual of bushy habit, with effective lavender, blue and white flowers. They stand our hot, dry climate and the plants are covered with bloom from early summer till frost.

1400-MIXED COLORS. Pkt., 10c; 3 pkts., $25 \mathrm{c} ; 0 z ., \$ 1.00$, postpaid.

1401-BLUE PERFECTION. Pkt., I0c; 3 pkts., 25c; oz., $\$ 1.00$, postpaid.

1717-LITTLE BLUE STAR. An exceedingly dwarf variety, very even in growth, the tiny bushes only about four inches high. Densely covered with bright blue flowers, with a darker near-purple center. A wonderful sort for edging. Pkt., 25c; 2 pkts., 45 c. 1733-BLUE BALL. This beautiful little plant is very compact in growth and covered with a mass of deep blue blooms. Account of its height it makes a wonderful border plant, growing only to a height of six inches. This variety seems to be more uniform in growth than others of the same family and will bloom over a long season. Pkt., 15c; 2 pkts., $25 \mathrm{c}$

\section{Argemone}

1716-ARGEMONE (Mexican Prickly Poppy). Has a very ornamental pale green foliage with clear silvery midrib and veins. Blooms are similar to the single poppy in shape and of satiny texture, measuring three inches or more across, in various shades from rich yellow to creamy white. It comes into hloom early in July and continues through the summer. It is best to sow the seed where they are intended to bloom just as soon a the ground is warm. Prefers light soil and a sunny location. A very pretty plant in or out of bloom. Pkt., 15c; 2 pkts., 25c, postpaid.

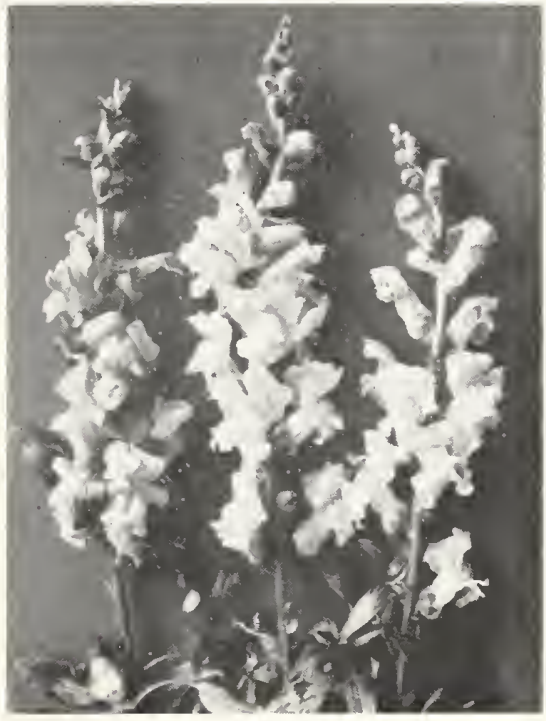

1597-Super-Giant Snapdragons

\section{Antirrhinum-Snapdragons}

Snapdragons are very hardy and easy to grow, and produce an abundance of flowers from the time they begin blooming in the spring until frost. They are among our most popular flowers, and are especially desirable for cutting. Plant either in the spring or fall.

\section{Maximum or Super-Giant}

This new strain of Snapdragons far surpasses anything yet introduced. Grows from three to four feet high. and the flowers are of magnificent size. We offer them in the following colors

1590-APPLE BLOSSOM. Rosy pink, white tube.

I591-CANARY BIRD. Canary-yellow.

1592-COPPER KING. Bronzy copper.

1593-OLD GOLD. Golden yellow, old rose throat.

1594-PURPLE KING. Deep velvety garnet. 1595-SNOWFLAKE. Pure white, with yellow tube.

1596-THE ROSE Rich rose-pink.

Price each of the above, pkt., 15c;2 pkts., $25 \mathrm{c}$, postpaid.

1597-MAXIMUM MIXED. Pkt., 15c; 2 pkts., 25c; oz., \$2.00, postpaid.

\section{Tall Snapdragons}

These grow about thirty inches tall, with long, graceful spikes carrying many large sized blooms. Our mixture includes a wide range of colors. Excellent for backgrounds or tall borders.

1406-TALL PINK.

1407-TALL SCARLET.

1408-TALL WHITE.

1409-TALL YELLOW.

Price of each, pkt., 10c; 3 pkts., 25c; 0z, $\$ 1.25$ postpaid.

1410-TALL MIXED. Pkt., $10 \mathrm{c} ; 3$ pkts., $25 \mathrm{c} ;$ oz., \$1.00, postpaid.

\section{Semi-Dwarf Snapdragons}

These grow from 18 to 20 inches tall, and are particularly good for bedding. The flowers are most wonderful, in many beautiful shades and tints.

1411-SEMI-DWARF MIXED. Pkt., 10c; 3 pkts., 25c; oz., \$1.50, postpaid. 


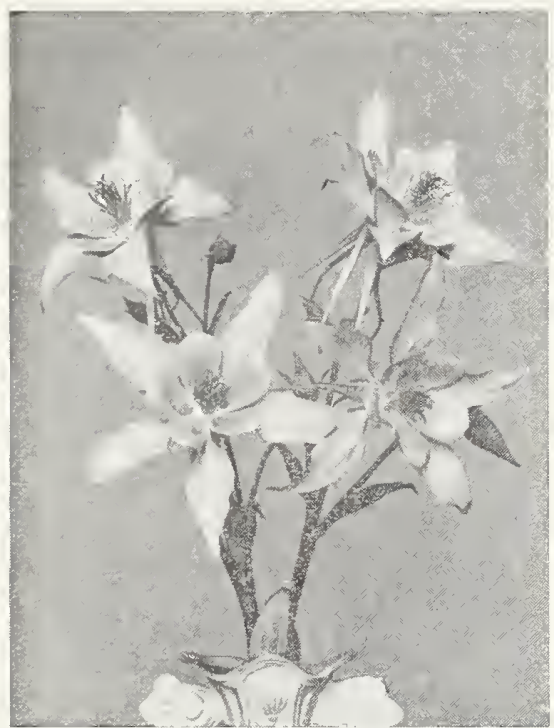

1640-Aquilegia-Columbine

\section{Aquilegia-Columbine}

Among hardy perennials, this is one of the easiest to grow from seeds. Much prized for cutting, the flowers and foliage both being very beautiful and decorative.

1707-ROCKY MOUNTAIN BLUE. Pkt., 10c; 3 pkts., 25c, postpaid.

1640-LONG SPURRED MIXED. The plants are of strong, thrifty growth, with large flowers of many colors. While all Aquilegias are beautiful, we believe this to be the finest variety yet produced, making a mass of harmonious coloring seldom seen in other flow. ers. Pkt., 15c; 2 pkts., 25c, postpaid.

\section{Arctotis}

Blue Eyed African Daisy

This is one of the best annual flowers to grow for cutting. It is easily grown from seed and may be started either in the house or the open ground, the seed germinating in just a few days. Starts blooming in early summer, and continues until hard frost. As a cut flower it is especially desirable, the blooms lasting a week or ten days in water. Grows 2 to 3 feet high. Has single, daisy-

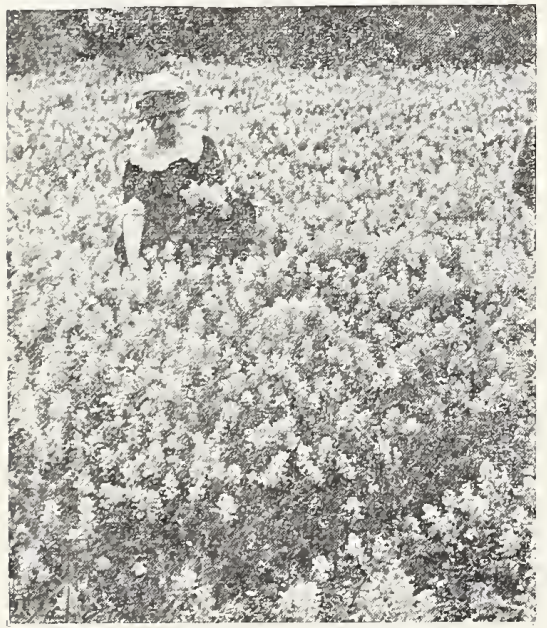

Field of Texas Blue Bonnet like flowers, pearly white with a gold band surrounding a delicate mave center.

1641-ARCTOTIS GRANDIS. Pkt., 10c; 3 pkts., 25c; oz., $\$ 1.00$, postpaid.

\section{Asters}

For early flowering, seed should be planted in hotbeds in December and January, then cransplanted as soon as the danger of frost is over.

1412-QUEEN OF THE MARKET. This is a good type for bedding, and also makes fine cut flowers. Plant grows about 15 inches high, and produces beautiful double flowers in many colors, earried on long, slender, graceful stems. Mixed. Pkt., 10c; 3 pkts. $25 c ;$ oz., \$1.50, postpaid.

1413-EXTRA EARLY EXPRESS. These Asters are the earliest blooming of any, and produce large and full double flowers that re very beautiful. Mixed colors. Pkt., 10c 3 pkts., 25c, postpaid.

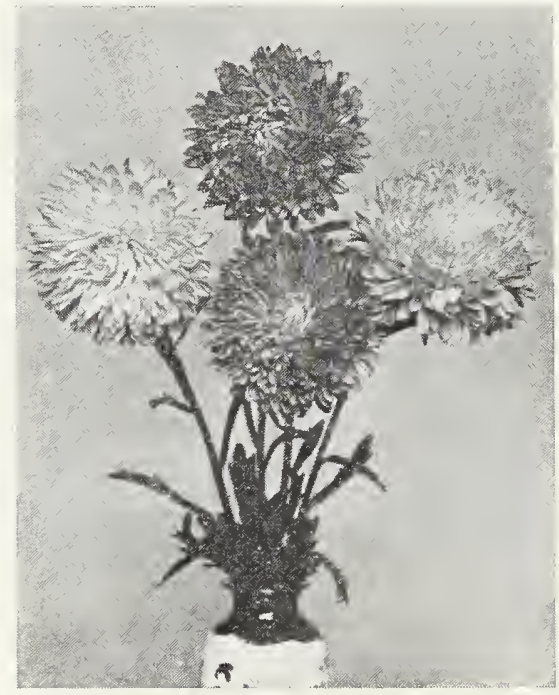

1413-Extra Early Express Asters

\section{Balsam}

Hardy annual that grows 18 inches to 2 feet tall, producing an abundance of brilliantly colored flowers. This plant also known as old-fashioned Touch-Me-Not.

1415-DOUBLE CAMELLIA MIXED. Pkt., $10 \mathrm{c} ; 3$ for $25 \mathrm{c}$; oz., $75 \mathrm{c}$, postpaid.

\section{4-Texas Blue Bonnet}

\section{(Lupinus Texensis)}

The Texas State flower. Grows wild all over the prairies of Central and South Texas. There is nothing more beautiful than the fields when the beautiful flowers are in bloom in the early spring. Plants grow to 12 inches high and are covered with beautiful dark blue flowers tinged with white. They will grow on poor as well as on rich soil. Sow the seed very early in the spring, or in August, September, October or November, covering about one-half inch deep. As the seeds are very hard, puncture each seed with a sharp needle and soak overnight before planting. If the weather is dry give them plenty of water. They bloom in Texas in March, April, and May. After maturing seed, the plant dies and the seed falls on the ground and comes up again the next spring. Price, pkt., 10c; 0z., 35c; 1/4 lb., 75c; lb. $\$ 2.50$ postpaid.

ORNAMENTAL FOLIAGE PLANTS Amaranthus Dusty Miller $\begin{array}{ll}\text { Canna } & \text { Kochia } \\ \text { Coleus } & \text { Ricinus }\end{array}$

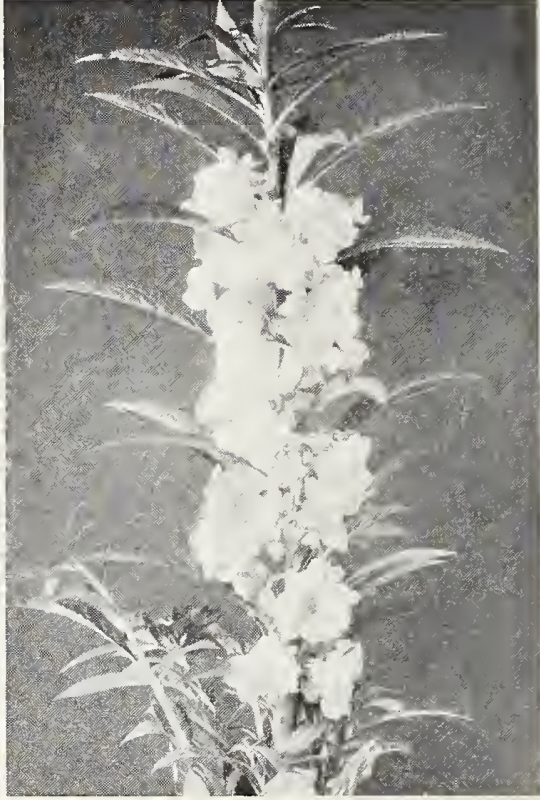

1415-Balsam

\section{Calendula}

Grows in any garden soil, making very effective beds or borders. One foot high. Blooms freely in spring.

1417-DOUBLE MIXED. Pkt., 10c; 3 pkts., $25 \mathrm{c} ;$ oz., 40c, postpaid.

1418-ORANGE KING. Very large and double, bright orange-red, dark eye; an extra fine strain. Pkt., 10c; 3 for 25c; oz., 50c, postpaid.

1642-CAMPFIRE. The flowers are extremely large, very dark orange with a scarlet sheen; long, strong stems, and is very desirable to grow for cutting. Pkt., 20c; pkts., 50c; oz., $\$ 1.50$, postpaid.

1643-LEMON QUEEN. Identical with Orange King in size and form, but a rich lemon-yellow in color. Pkt., 10c; 3 pkts., $25 \mathrm{c}$; oz., 50c, postpaid.

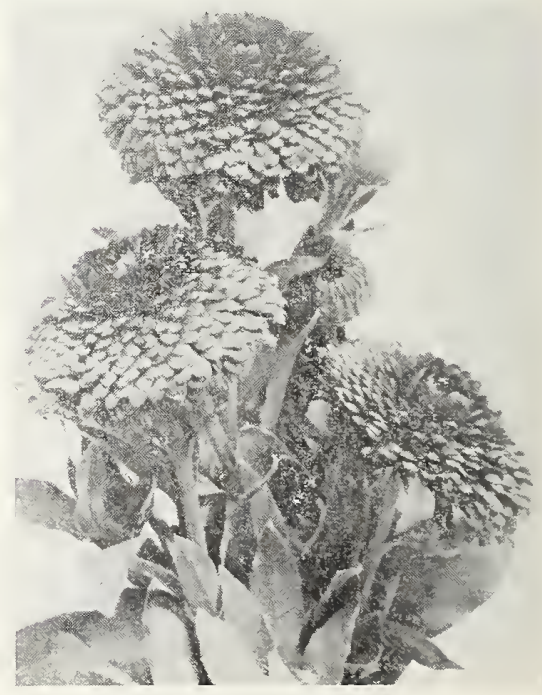

1642-Campfire-Calendula 


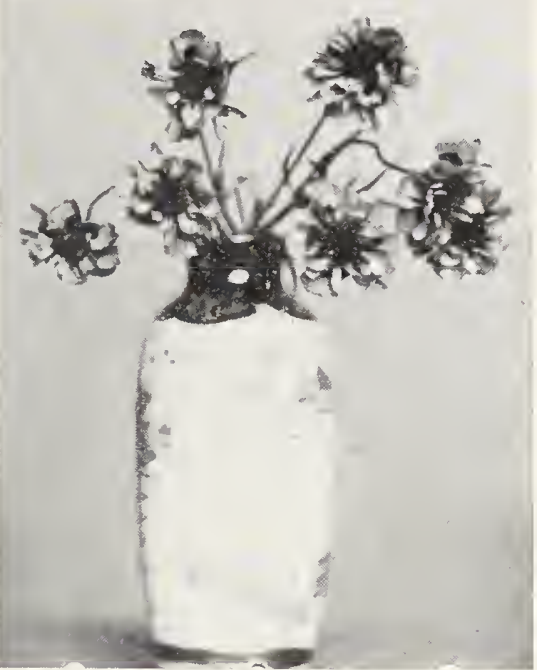

1416-Calliopsis

\section{Calliopsis}

Showy, free-flowering annual. A splendid summer bloomer, doing well in sunny places. Single flowers with a dark red eye. By keeping old flowers cut off plants will produce blooms until frost.

1416-TALL ANNUAL MIXED. Pkt., 10c 3 pkts., 25c; oz., 50c, postpaid.

\section{Candytuft}

Prolific bloomers, bearing in profusion clusters of flowers in a wide range of colors. Indispensable for cutting and very effective in beds or borders. Thin out to 4 inches in row

1420-GIANT WHITE HYACINTH FLOWERED. This is an extra select strain of Candytuft, with enormous trusses of white blooms, especially desirable for cutting. Grows about 18 inches high. Pkt., 10c; 3 pkts., 25c; oz.. 75c, postpaid.

1421-CRIMSON. 1423-LAVENDER.

1422-PINK. 1424-MIXED.

Price of each, pkt., 10c; 3 pkts., 25c; oz., 50c, postpaid.

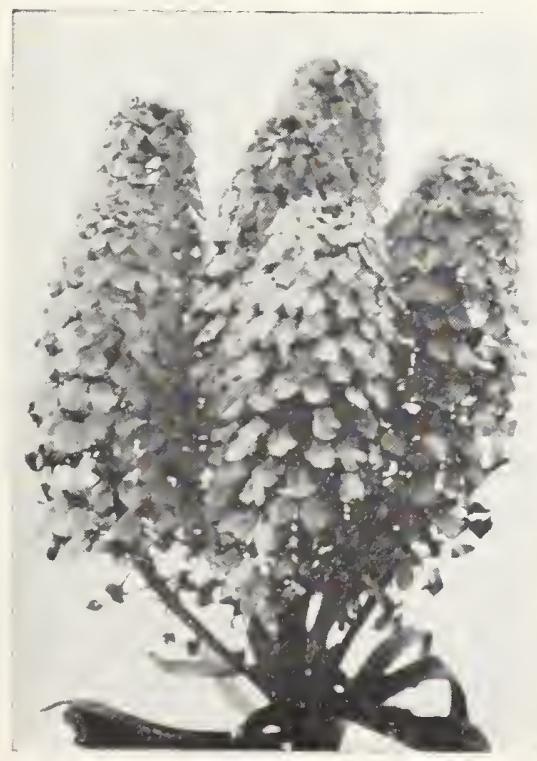

1420 - Candytuft

\section{Cannas}

Plants make large, broad leaves, producing clusters of large flowers of many different brilliant colors. By regular watering they will grow to a giant size.

1419-MIXED COLORS. Pkt., 10c: 3 for 25c; oz., 50c, postpaid.

$$
\text { For Canna Roots, see page } 18 .
$$

\section{Carnations}

Carnations are a great favorite with most people who take pride in their old-fashioned gardens. They have the most beautiful colors and are easily raised the first year from seed.

1429-MARGUERITE. Finest double mixed. Plants of this very fine strain may be made to produce blooms in 4 to $41 \frac{2}{2}$ months. Flowers large, double, fringed and fragrant. Desirable for bedding and cutting. Pkt., 10c; 3 for $25 \mathrm{c}$; oz., \$1.50, postpaid.

$1430-C H A B A U D^{\prime} S$ GIANT EVERBLOOM ING. Mixed colors. A magnificent strain of double Carnations, blooming in five months after being sown, and continuing to bloom indefinitely. Pkt., 25c; 5 pkts., \$1.00; oz., $\$ 3.00$.

\section{Castor Bean-Ricinus}

Tall, large plants with large palmlike leaves of a bright green and variegated color. Makes a splendid background but generally grown in groups like Cannas.

1584-GIANT ZANZIBARIENSIS. Pkt. 10c; oz.. $25 \mathrm{c} ; 1 / 4 \mathrm{lb} ., 75 \mathrm{c}$, postpaid.

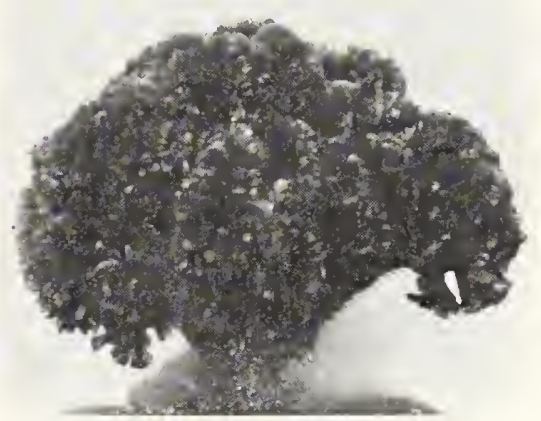

1425-Dwarf Cockscomb

\section{Celosia-Cockscomb}

An old picturesque class of plants. They form the gayest possible decoration in beds and borders, growing best in light soils.

1425 - DWARF COCKSCOMB (Glasgow Prize). Resembles a large comb of deep purplish red foliage. Pkt., 10c; 3 pkts., 25c; oz., $\$ 1.50$, postpaid.

1426-TALL COCKSCOMB. Crimson. Pkt. $10 \mathrm{c} ; 3$ pkts., 25c; oz., $\$ 1.00$, postpaid.

1427-PLUMOSA (Feathered Cockscomb). Plants 2 or more feet high, covered with brilliantly colored plumes of red, yellow or violet. Pkt., 10c; 3 pkts., 25c; oz., \$1.00, postpaid.

1428-CHILDSI (Chinese Woolflower) Plants about $2 \frac{1}{2}$ feet high, branch freely and produce large, globular, purplish crimson flowers, which resemble a ball of brilliant colored wool. Pkt., 10c; 3 pkts., 25c; oz., $\$ 1.50$ postpaid.

\section{Chrysanthemum}

Hardy summer-flowering annuals. Grow about 2 feet high, bearing an abundance of daisy-like flowers. These annuals are not winter-flowering sorts sold by florists, which are propagated from roots.

1437-DOUBLE MIXED. Pkt., 10c; 3 pkts., $25 \mathrm{c}$; oz., 50c, postpaid.

1438-SINGLE MIXED. Pkt., 10c: 3 pkte. 25c : oz., 50c, postpaid.

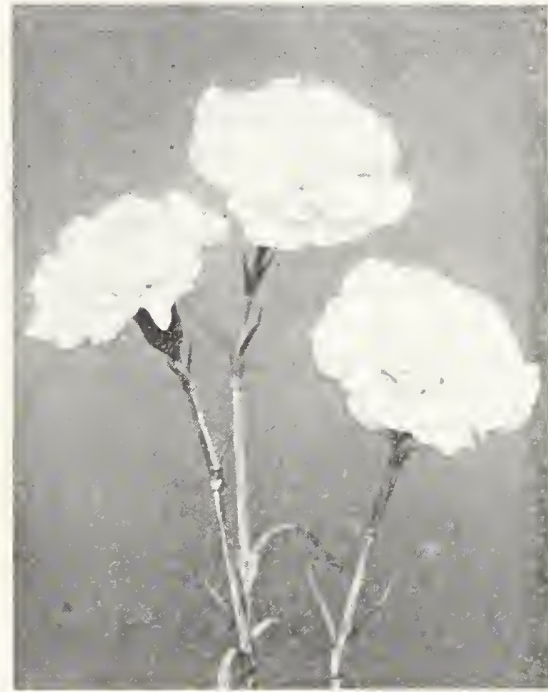

\section{$1430-$ Carnation
Centaurea}

They are favorites in all sections of the country. A very hardy annual, will grow and do well everywhere: great for cut flowers. 1431-CYANUS DOUBLE MIXED (Cor Flower). Also known as "Bachelor Button". and "Ragged Sailor". This is a splendid mixture of all existing shades and colors. Pkt. 10c; 3 pkts., 25c; oz., 40c, postpaid.

1432-CYANUS DOUBLE BLUE (Corn flower or Blue Bottle). Pkt., 10c; 3 pkts. $25 \mathrm{c} ;$ oz., $75 \mathrm{c}$, postpaid.

1433-DUSTY MILLER. With silvery white, broad leaves. A very decorative plant for use in borders or for edging. Pkt. 10c: 3 for $25 \mathrm{c}$; oz.. $\$ 1.00$, postpaid.

1434-IMPERIALS (Sweet Sultan). One of the most satisfactory flowers for cutting. Very easy to grow; bear on long, stiff stems, beautiful flowers of pink, lavender. white and other colors, that live for over week when cut and placed in water. Pkt. $10 \mathrm{c} ; 3$ pkts., $25 \mathrm{c}$; oz., $75 \mathrm{c}$, postpaid.

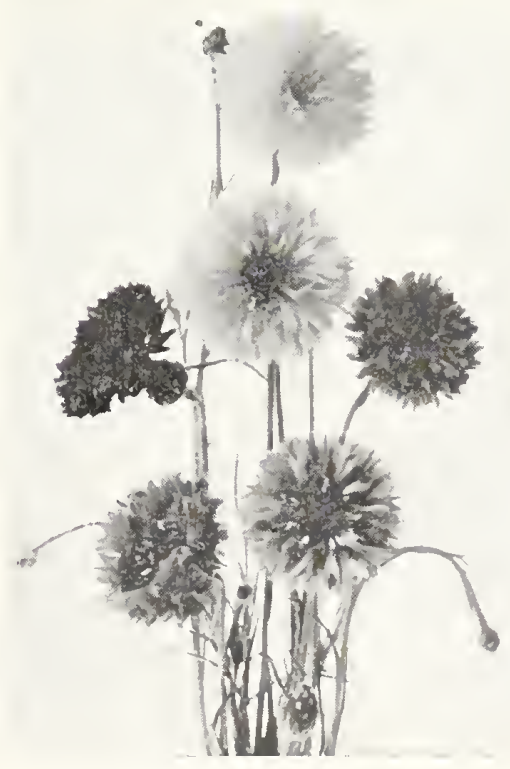

1431-Centaura-Double Mixed 


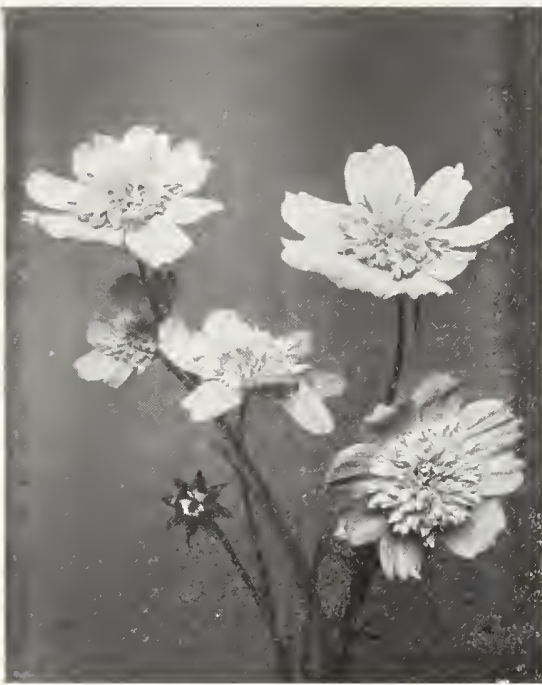

1440-Cosmos-Giant Double Crested

\section{Coreopsis}

No flower is longer in bloom during the whole season than Coreopsis. It is most excellent for cut flowers, lasting well. Bright yellow flowers, attractive and showy. Hardy perennial, easily grown from seed. 2 feet.

1435-LANCEOLATA GRANDIFLORA. A wonderful plant that seems to be especially adapted to Southern elimate. This is the old reliable sort that we have known for years. Pkt., 10c: 3 pkts., 25c; oz., 50c, post paid.

1734-AURICULATA SUPERBA G. F. A large bloomer measuring 3 inches across. The beautiful flowers, though single, have a serrated band of brownish-red encircling the golden dise, making it truly attractive. Flower lovers will find this to be a wonderful ađdition to their collection. Pkt., 25c; 5 pkts., $\$ 1.00$.

1735-DOUBLE YELLOW. Produces an abundance of double and semi-double flowers that have an appearance of a beautiful golden wave when in full bloom. The long stem blooms are excellent for cut flowers and are growing in popularity with the best florists. Pkt., 15c; 2 pkts., 25c.

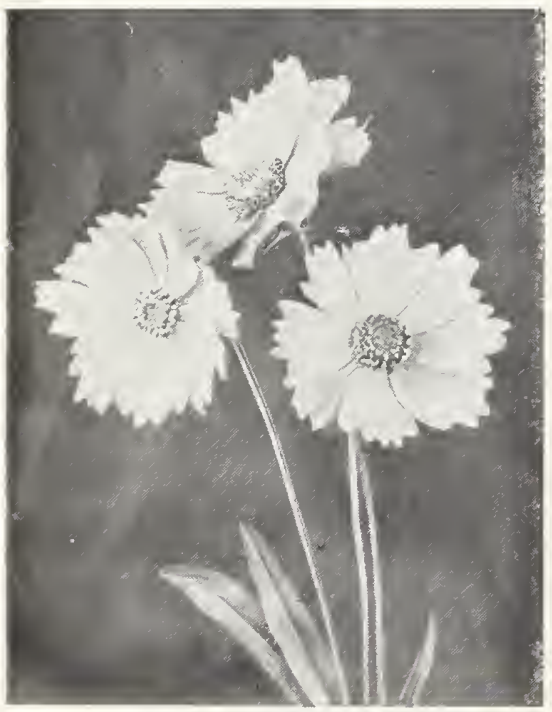

1435 -Coreopsis

\section{Cosmos}

A hardy and fast growing annual. Plant 3 to 5 feet high, with feathery green foliage, producing in a variety of colors, single and double flowers on long, graceful stems. This is one of the best flowers to grow for cutting. 1439-GIANT SINGLE MIXED. Grows very tall, with flowers as large as 4 inches in diameter. Pkt., 10c; 3 pkts., 25c; 0z., 75c, post paid.

1440-GIANT DOUBLE CRESTED MIXED. The flowers are large and have a double center, which stands out from the outside row of single petals. The flowers after cutting last a long time in water. Pkt., 10c; 3 pkts., 25c; oz., $\$ 1.50$, postpaid.

1441-EXTRA EARLY SINGLE MIXED. Pkt., 10c; 3 pkts., 25c; oz., 75c, postpaid.

1442-EXTRA EARLY DOUBLE CRESTED MIXED. Pkt., 15c; 2 pkts., 25c; oz., \$2.50, postpaid.

1443-KLONDYKE. This is one of the finest varieties of Cosmos, producing large, golden yellow single flowers, blooming all during the late summer and fall. This is one of the best flowers to grow in the South, and is being planted more and more each year. Pkt., 10c; 3 pkts., 25c; oz., $\$ 1.00$, postpaid.

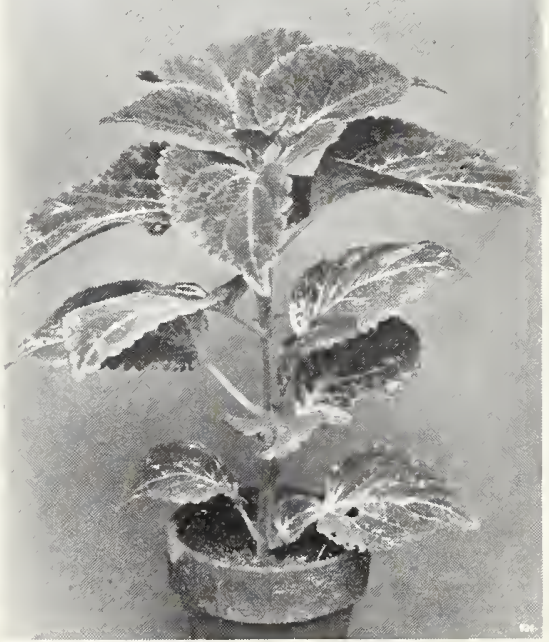

1685 -Coleus

\section{Coleus}

Handsome foliage plant, fine for bedding and stands the sun well; also fine house plants. Extra choice.

1685-MIXED. Pkt., 25c; 5 pkts., $\$ 1.00$, post paid.

\section{Cherianthus}

1718-CHERIANTHUS (Allioni). An unusually bright and showy biennial that will bloom from seed the first year. Splendid for rockery. This variety grows about 12 inches high with heads of brilliant orange-colored flowers. You will make no mistake in giving Cherianthus a trial. Pkt., 15c; 2 pkts., $25 \mathrm{c}$.

\section{Campanula-Canterbury Bells}

This is one of the best of the old-fashioned flowers, and is very easy to grow, preferring a rich, moist soil. Flowers are of many colors, growing in the shape of a cup and saucer.

1585-MIXED. Pkt., 10c; 3 pkts., 25c, postpaid.

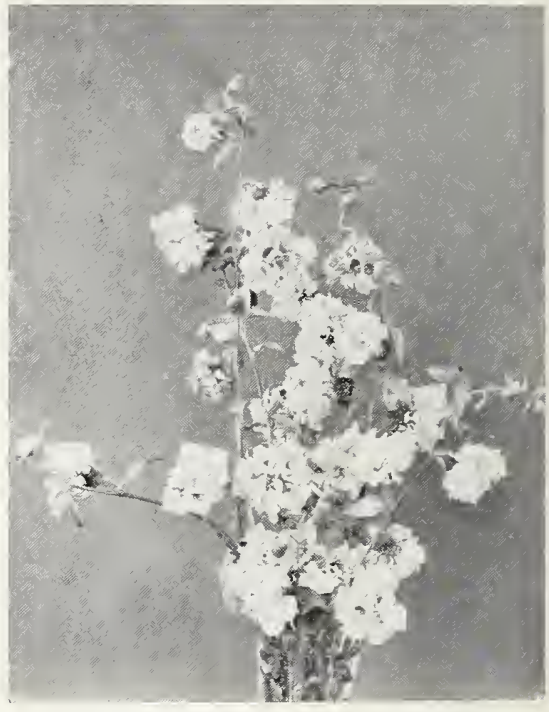

1736-Clarkia Double Mixed

\section{Clarkia Elgans}

1736-DOUBLE MIXED. A very pretty old annual that has been greatly improved in recent years. It is a flower that is used to a great extent in Europe as a cut flower bearing leafy racemes of double blooms which all open in water when cut. Does well either in sun or shade. Pkt., 10c; 3 pkts., 25c; oz., $\$ 1.00$.

\section{Cleome}

1737-PUNGENS. So often called Giant Spider Flower. The plants will grow $2 \frac{1}{2}$ to $31 / 2$ feet high, covered with large heads of spider-like, rose-colored flowers. Used to a great extent in public parks of many sections, making a striking subject for large beds or for interspersing in the shrubbery border. It is an annual and seed should be sown in open ground at the first approach of spring. Give the plants sufficient room to develop their full beauty. Pkt., 10c; 3 pkts., 25c.

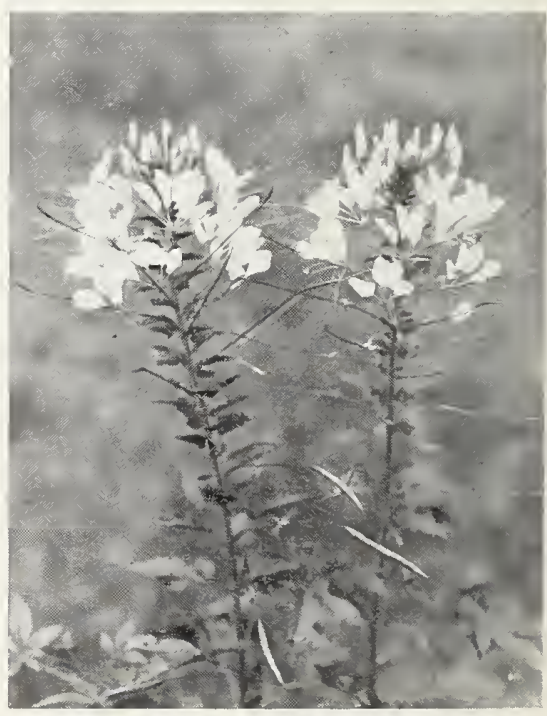

1737-Cleome 


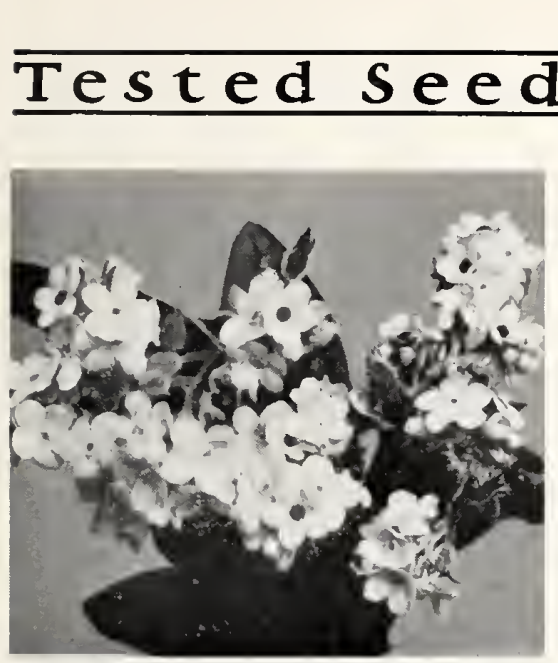

1649-Cynoglossum

\section{Cynoglossum}

1649-CHINESE FORGET-ME-NOT. This is a new Forget-Me-Not introduced from China, and seems to be perfectly adapted to our climate, whereas the old-fashioned Forget-Me-Nots were rather hard to grow. Has the same Forget-Me-Not blue flowers, with a much stronger plant, growing about 18 inches high, and blooming throughout the summer

\section{Delphinium}

This is Perennial Larkspur, and one planting lasts for several years. Flowers are various shades of blue, and the plant grows about five feet tall. Should be planted in. doors and transplanted to permanent beds in early spring.

1714-DEEP BLUE. Pkt,, 15c; 2 pkts., 25c, postpaid.

1715-LIGHT BLUE. Pkt., 15c; 2 pkts., $25 \mathrm{c}$, postpaid.

1682-MIXED. Pkt., 10c; 3 pkts., 25c, postpaid.

\section{Dahlias}

Particularly fine for cut flowers, but are also most suitable for garden decoration. Will bloom first season.

1448-DOUBLE MIXED. Pkt., 15c; 3 pkts.,

1449-SINGLE MIXED. Pkt., 10c; 3 pkts., 25c.

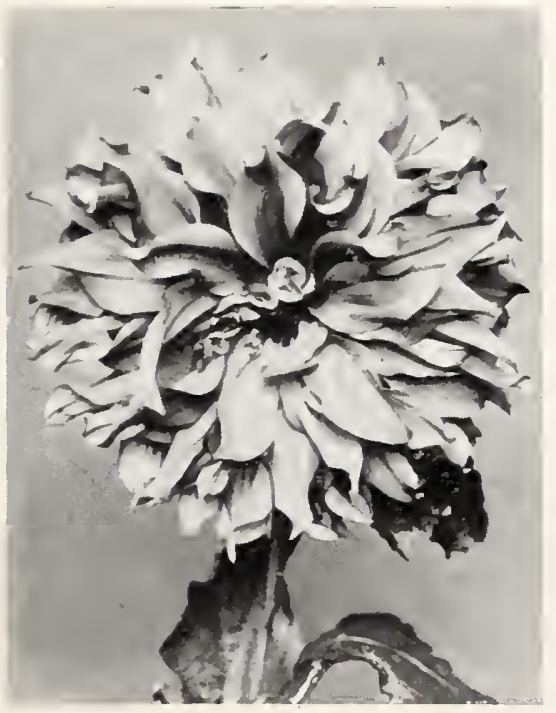

1448-Double Dahlia
Daisies

1450-SHASTA DAISY. Well known perennial, about two feet high, beautiful flowers with pure white petals, with golden center. Fine for cut flowers. Pkt, 10c: 3 pkts., 25c: oz. $\$ 2.25$, postpaid.

1451-DOUBLE ENGL1SH DAISY (Bellis Perennis.) Charming little plants for edging and borders. Also used for low beds. Double mixed, pkt., 10c; 3 pkts., 25c; oz., $\$ 2.00$, postpaid.

1452-SWAN RIVER DAISY (Brachycome.) Charming little plants that delight in a sunny situation, fine for edgings; color. light blue. Pkt., 10c; 3 pkts., 25c; oz., \$1.50, post paid.

1453-AFRICAN DAISY (Dimorphotheca.) Beautiful new Daisy of easy culture, 12 inches high. Mixed colors. Pkt., 10c; 3 pkts., 25c; $0 z ., \$ 1.25$, postpaid.

BLUE-EYED AFRICAN DAISY. See Arctotis.

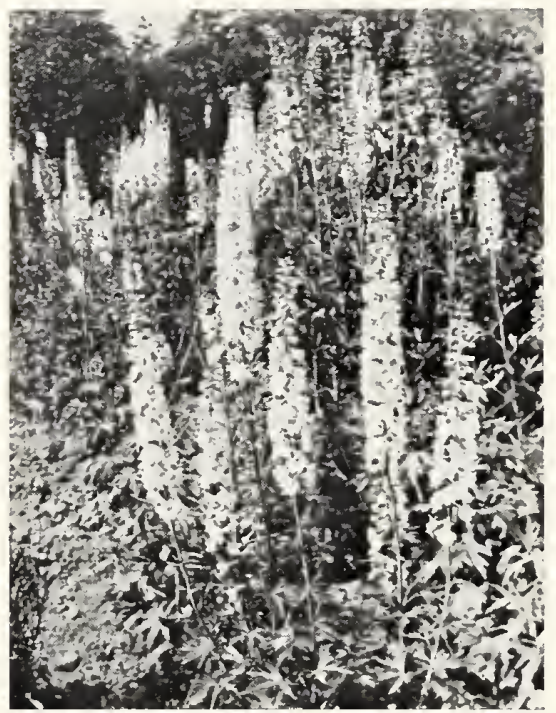

1682-Delphinum-Mixed

\section{Didiscus}

(BLUE LACE FLOWER)

1454-COERULEUS. This pretty and interesting annual blooms most profusely from July till November; their exquisite pale lavender blossoms are excellent for cutting: plants grow about 18 inches high, and have as many as 50 flowers open at one time. Pkt., 10c; 3 for 25c; oz., $\$ 1.00$, postpaid.

DUSTY MILLER. See Centaurea.

\section{Erigeron}

(MIDSUMMER DAISY)

Highly prized summer-flowering plants with elegant single aster-like flowers. Very desirable for cutting.

1644-ERIGERON SPECIOSUS. Grows about 24 inches high, with large, rich purple flowers. Pkt., 20c; 3 pkts., 50c, postpaid.

\section{Eschscholtzia}

\section{CALIFORNIA POPPY}

This is the State flower of California. I very desirable for every flower garden.

1455-AURANTIACA. Best orange. Pkt. $10 \mathrm{c} ; 3$ pkts., $25 \mathrm{c}$; oz., $40 \mathrm{c}$, postpaid.

1457-SINGLE MIXED. The above color and many others in mixture Pkt, 10c; 3 pkts., 25c; oz., 40c, postpaid.

1458-DOUBLE MIXED. This mixture produces beautiful double flowers in white and yellow colors. Pkt., 10c; 3 pkts., 25c; oz., $\$ 1.00$, postpaid.

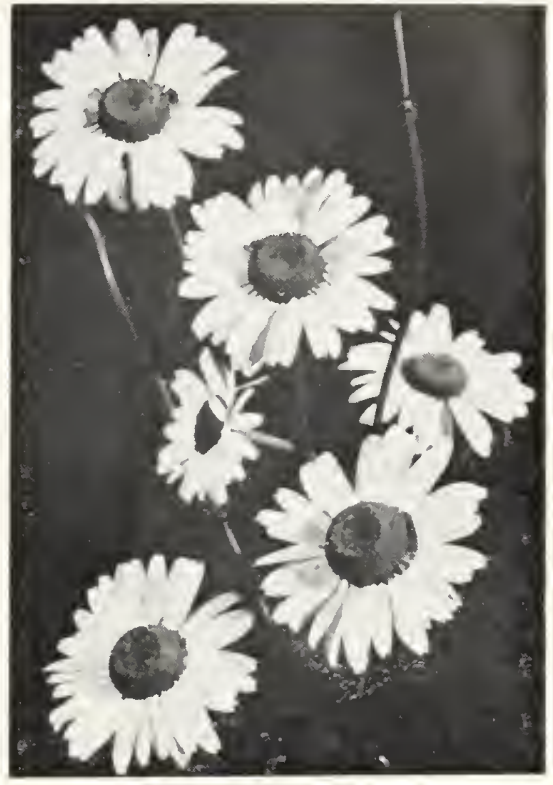

1450-Shasta Daisy

Everlasting Flowers

(Old-Fashioned Straw Flower)

They are exceedingly beautiful, of many rich colors, make a fine display in beds and borders. If wanted to use dry in baskets or vases throughout the winter, cut the stems as long as possible when the blossoms are about one-third open, then tie in bunches and hang with heads downward in some dry place until cured.

1445-ACROCLINIUM. These produce beautiful flowers that can be used for winter bouquets. Double mixed. pkt., 10c: 3 pkts. $25 \mathrm{c}$; oz., 50c, postpaid.

I446-GLOBE AMARANTH (Gomphrena Globosa.) Old-Fashioned Bachelor Buttons. A beautiful everlasting, valued for its handsome, small, globular flower heads. Halfhardy annual; 12 to 18 inches high. Double mixed, pkt., 10c; 3 pkts., $25 \mathrm{c}$; oz., 50c, postpaid.

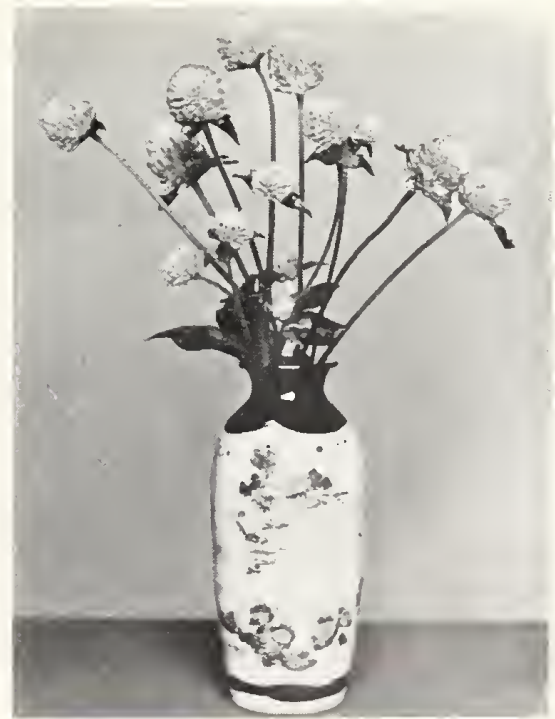

1446-Globe Amaranth 


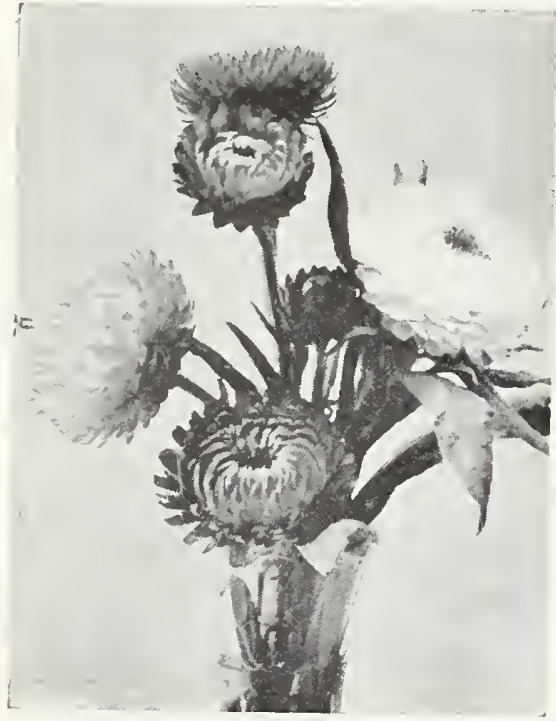

Everlasting Flowers

(Continued)

Helichrysum

These are classed by many as the best and most satisfactory of the Everlastings flowers and make beautiful dry bouquets. Account of the popularity of this flower, we have added separate colors.

1520-CANARY. A true shade.

1521-CRIMSON. A vivid crimson that will retain its color when dried.

1522-ROSE QUEEN. A large bloom with various shades of bright rose.

1523-SILVER BALL. A novelty in color. 1524-V1OLET QUEEN. A rich and intense violet color.

Price of each: pkt., 10c; 3 pkts., 25c; oz., $\$ 1.25$.

1444-MIXED. An array of color that will please. Pkt., 10c; 3 pkts., 25c; oz., $\$ 1.00$.

1447-RHODANTHE. One of the most beautiful Everlastings. The flower heads are somewhat bell-shaped, becoming, when mature, fully expanded and sometimes reflexed. They are gracefully poised on slender stems. Pkt., 10c; 3 pkts., 25c; oz., 50c, postpaid.

STATICE-SEA LAVENDER. Lovely quaint hardy perennial. Large, showy, spreading panicles of graceful flowers, much prized for winter decoration when dried.

1680-M1XED. Pkt., 10c; 3 pkts., 25c; oz. $\$ 1.00$, postpaid.

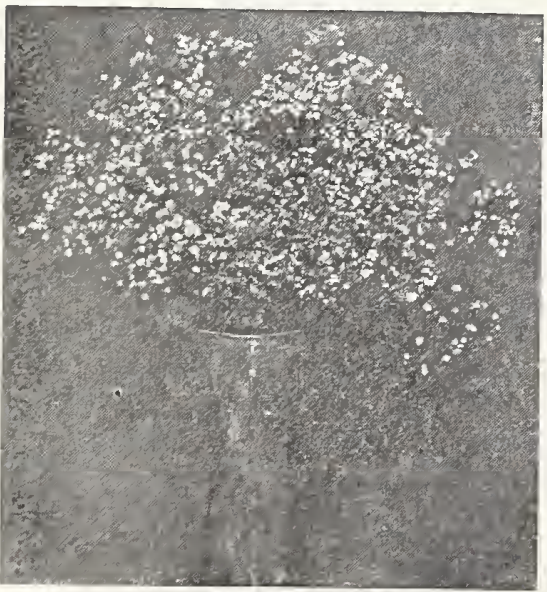

1465-Gypsophila-Paniculata

\section{Four O'Clock}

\section{(MARVEL OF PERU)}

A beautiful old-fashioned flower, producing an abundance of highly colored flowers. Blooms continually until frost; grows about 2 feet high.

1460-MIXED. Pkt., 10c; 3 pkts., 25c; oz., $30 \mathrm{c}$, postpaid.

FEVERFEW. See Matricaria.

\section{Foxglove}

1459-DIG1TALIS - FOXGLOVE. .. Grows about 4 feet high. Plants do well in shady locations. Hardy biennial or perennial, usual. ly blooming the second year. Pkt., 10c; 3 pkts., 25c; oz., \$1.00, postpaid.

\section{Gaillardia}

Also known as "Blanket Flower". A hardy annual of easy culture that is well adapted to our climate, and very satisfactory to grow in mixed borders or for cutting. The daisylike flowers are large and beautiful, with shades of red and yellow. Blooms throughout the entire season.

1463-GRANDIFLORA SUPERBA MIXED. Pkt., 10c; 3 pkts., 25c; oz., \$1.00, post paid.

\section{Geranium}

This variety is very desirable for pot culture flower boxes and bedding outdoors. Seed should be sown inside house in pots or boxes in rather light soil and should be kept moist. Seed is slow to germinate.

1461-M1XED. Pkt., 15c; 2 pkts., 25c; 1/4 oz., $75 \mathrm{c}$, postpaid.

\section{Geum}

1462-MRS. BRADSHAW. An attractive perennial, producing showy scarlet flowers on long stems. Blooms profusely all during the summer; height 2 feet. Pkt., 15c; 2 pkts., 25c; oz., $\$ 2.50$, postpaid.

\section{Gila}

A beautiful annual growing about two feet high with fine feathery foliage and bearing freely over a long season globular heads about one inch across. Blooms last well when cut.

1738-CAPITATA. Rich lavender blue. Pkt., $10 \mathrm{c} ; 3$ pkts., $25 \mathrm{c}$.

\section{Gypsophila}

(ANGEL OR BABY BREATH)

Pretty free-flowering, elegant plants, succeeding in any garden soil. Their misty white panicles of bloom are largely used for mixing with other cut flowers.

1464-ELEGANS GRANDIFLORA (Annual.) White. Pkt., 10c; 3 pkts., 25c; oz., $60 c$, postpaid.

1465-PANICUlata. White. Very desir. able for cutting. Is a hardy perennial, but will bloom the first year if seed is sown early. Pkt., 10c; 3 pkts., 25c; oz., 60c, postpaid.

\section{Heliotrope}

1466-HELIOTROPE. A half-hardy perennial flowering during the entire season. Seed planted in early spring will make fine plants for summer blooming. The robust plants produce an abundance of delightful, perfumed flowers which make them most desirable for bouquets. Pkt., 10c; 3 pkts., 25c; oz., $\$ 2.50$, postpaid.

\begin{tabular}{|cc}
\hline FOR HEDGES \\
Salvia & $\begin{array}{c}\text { Splendens } \\
\text { Four O'Clock }\end{array}$ \\
\hline
\end{tabular}

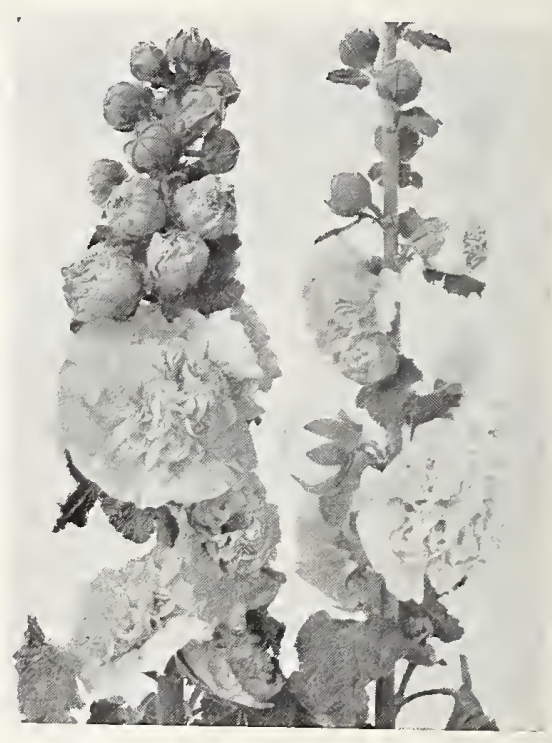

1472-Hollyhock-Double Mixed

\section{Hollyhocks}

This splendid old-fashioned perennial is almost unlimited in its production of bril liantly colored flowers, ranging from deep yellow, red, to pure white. Plant in early spring and then thin; transplant if desired Double varieties are hardy perennials; set 4 to 5 feet apart.

1468-DOUBLE PINK

1469-DOUBLE SCARLET

1470-DOUBLE SALMON

1471-DOUBLE YELLOW

1472-DOUBLE MIXED

Price of each, pkt., 10c: 3 pkts., 25c; oz. 1.75 .

1473-SINGLE MIXED

Price, pkt., 10c; 3 pkts., 25c; oz., \$1.00.

\section{Hibiscus}

1467-AFRICANUS. Large, white with black eye. The plants produce immense, showy flowers in great abundance from June until late fall. Height from 3 to 4 feet. Grow best in moist soil; should have plenty of water during growing season. Pkt., 10c; 3 pkts., 25c; oz., $75 \mathrm{c}$, postpaid.

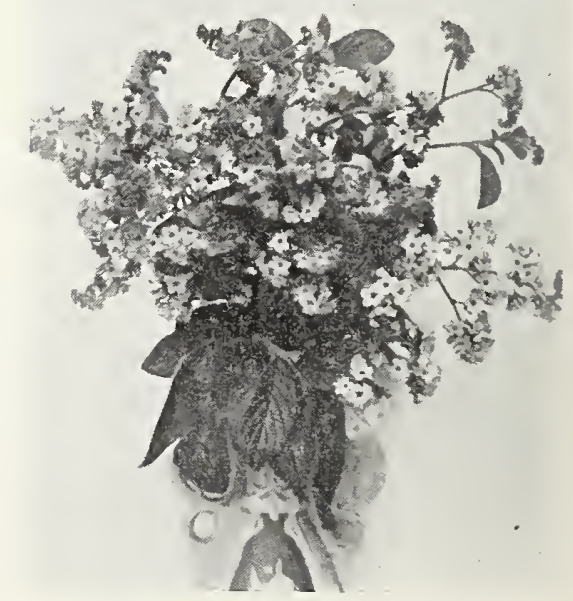




\section{Tested Seeds for

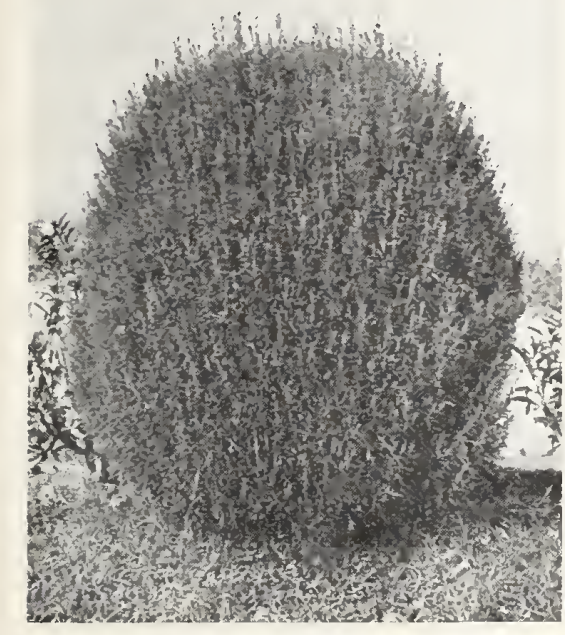

\section{5-Kochia}

(Mexican Fire or Burning Bush) The most symmetrical and attractive hedge plant that grows. It forms a globe-shaped bush about 3 feet high. Foliage is fine like moss, of a very bright green color. When the frost comes in the fall the bush turns a deep red. Very valuable for any kind of hedge display. Sow seed in boxes, then trans. plant as soon as danger of frost is over. Plant in rows 18 inches to 2 feet apart. A very hardy annual. Pkt., 10c; 3 pkts., $25 \mathrm{c}$ : oz., 40c, post paid.

\section{4-Ice Plant}

A tender annual of trailing habit used mostly for hanging baskets, rock work, flower boxes, edgings; leaves and stems succulent, appearing to be covered with ice crystals. Pkt., $10 \mathrm{c} ; 3$ pkts., 25c; oz., 60c, post paid.

\section{Lantana}

1476-FRENCH HYBRIDS MIXED. Popular, free-blooming and very rapid growing with flower heads of various colors, which are continually changing; emit a powerful

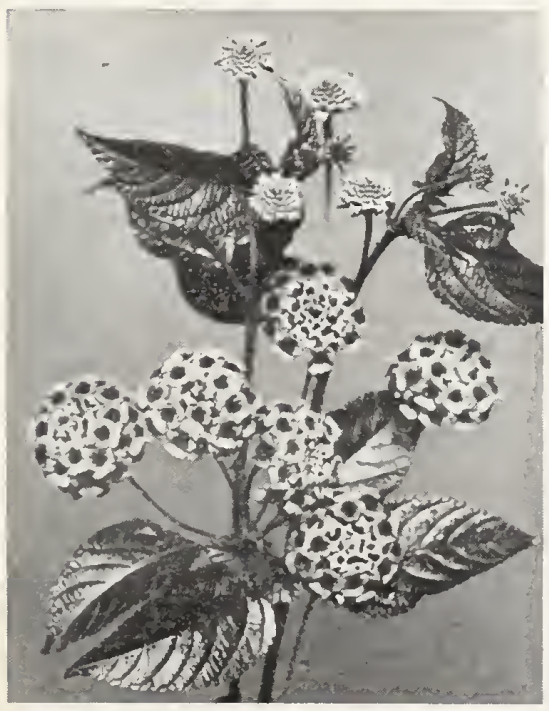

1476-Lantana aromatic perfume. Plants are completely loaded with blossoms, succeeded by berries, which, when ripe, turn deep blue. Pkt., 10c pkts., 25c; oz., 75c, postpaid.

\section{Larkspur}

One of the most popular annuals, produc ing long stems of double flowers in all shades and colors. All our Larkspurs are of the stock-flowered kind. A bed of Larkspurs and Poppies mixed, planted in the late fall, will make a very beautiful display in the spring.

1478-DOUBLE TALL BLUE

1479-DOUBLE TALL SKY-BLUE

1480-DOUBLE TALL WHITE

1481-DOUBLE TALL SCARLET

1482-DOUBLE TALL PINK

1483-DOUBLE TALL PURPLE

1184-DOUBLE TALL MIXED

1485-DOUBLE DWARF MIXED

Price of each, pkt., 10c; 3 pkts., 25c: oz., 75c, postpaid.

\section{Lavateria}

(Annual Mallow)

A beautiful and showy annual that grows three to four feet high, covered during the summer with large rose pink blooms, making it mest decorative when planted in hedges or background borders. The blooms will measure 2 to 3 inches across. The large cup-shaped flowers are borne on short stems in the axils of the upper leaves. It is a quick grower and rather spreading.

1719-SPLENDENS ROSEA. Pkt., 10c; 3 pkts., 25c.

\section{Linium}

(Scarlet Flax)

This member of the flax family has blooms that are so exceptionally attractive and bril. liant that it is now a favored bedding plant. liant that it is now covered with scarlet-crimson flowers. A hardy annual and a bloomer of long duration

1720-GRANDIFLORUM RUBURM. Pkt., 10c: 3 pkts. $25 \mathrm{c}$.

\section{Marigold}

An old favorite annual, when grown in An mate to perfection: bloom clear up to frost.

1726-ORANGE PRINCE. Truly an alldouble. This is the type of Marigold that you see featured by the better florists. Large, perfect double quilled flowers of a rich deep golden-orange color. Do not fail to try this prize-winning Marigold. Pkt., 15c; 2 pkts., $25 \mathrm{c} ;$ oz., $\$ 1.50$.

1727-LEMON QUEEN. A counterpart of Orange Prince excent in color, which is a soft lemon yellow. Pkt., 15c; 2 pkts., 25c; oz., \$1.50.

1489-TALL AFRICAN DOUBLE MIXED. Pkt., 10c; 3 pkts., 25c; oz., 75c, post paid.

1490-TALL FRENCH DOUBLE MIXED. Pkt., 10c; 3 pkts., 25c; oz., 60c, postpaid.

1646-DWARF FRENCH DOUBLE MIXED. Pkt., 10c; 3 pkts., 25c; oz., 60c, postpaid.

1647-DWARF FRENCH LEGION OF HONOR. A single-flowering Marigold, forming compact bushes 9 inches high. Begins flowering early, and continues until frost. The flowers are golden yellow, marked with a spot of velvety crimson at the base of each petal. Pkt., 10c; 3 pkts., 25c; oz., $\$ 1.00$ postpaid.

1648-DWARF FRENCH DIADEM. This is another excellent single variety, with ver attractive flowers of mahogany-red, edged in gold. Pkt., 10c; 3 pkts., 25c; oz., \$1.00, postpaid.

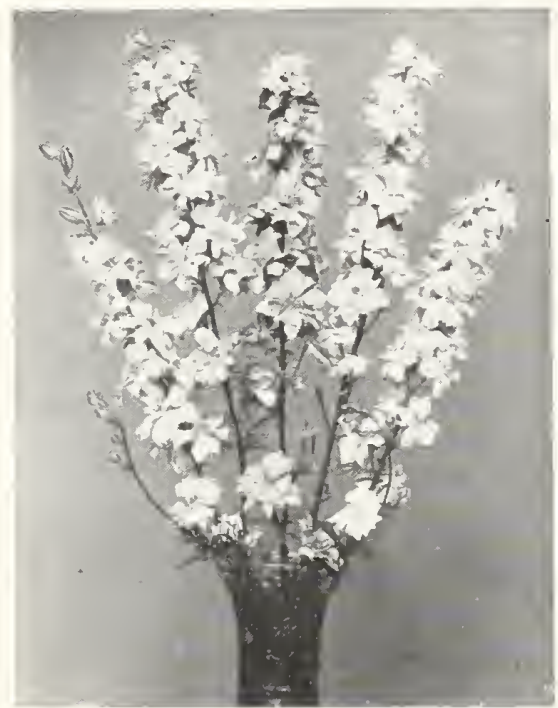

1478-Larkspu

\section{Lupine-Lupinus}

1477-TALL DOUBLE MIXED. Free-flow. ering, easily grown annuals, with long, graceful spikes of rich and various colored, pea. shaped flowers: valuable for mixed borders, beds and for cutting; prefers a little shade. 2 feet. Fine mixed, pkt., 10c; 3 pkts., $25 \mathrm{c}$ oz., 40c, postpaid.

LOVE-IN-A-MIST. See Nigella, Page 10 Mignonette

1486-MACHET. An old time favorite sweet-scented annual growing about 12 inches high. Plant in rows 12 inches apart and 6 inches in row. Thrives best in cool places and in rather light soil. Pkt., 10c: 3 pkts. 25c; oz., 50c, postpaid.

FOR HANGING BASKETS AND WINDOW BOXES

$\begin{array}{ll}\text { Ageratum } & \text { Ice Plant } \\ \text { Alyssum } & \text { Nasturtium } \\ \text { Candytuft } & \text { Pansies } \\ \text { Coleus } & \text { Petunias (Balcony) }\end{array}$

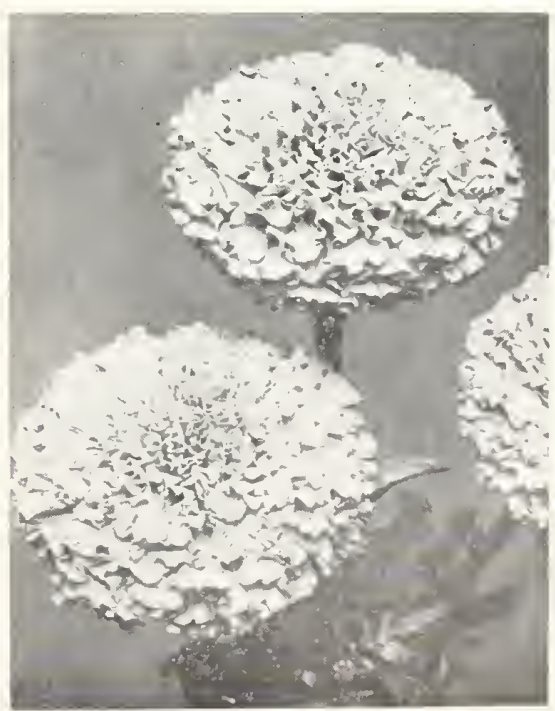

1726-Marigold-Orange Prince 


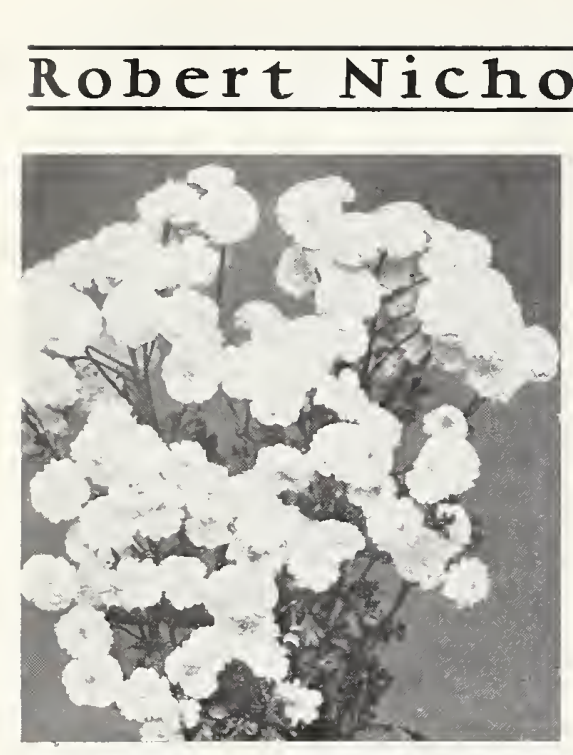

1728-Matricaria-Feverfew

\section{Matricaria}

(Feverfew)

1728-MATRICARIA CAPENSIS ALBA PLENA (Double White Feverfew). This wonderful plant has attracted more attention than any other we may know of, as so few flower lovers know what it is. Sometimes called button chrysanthemums and is a member of the mum family. Dozens of the small blooms are borne on a single stem of the plant and a few stems with a bit of fern will make a beautiful centerpiece. The cut blooms will stay fresh for a long time. It is our suggestion that you plant the seed early and enjoy a mass of blooms the first season. Grows 18 inches high. Pkt., 10c; 3 pkts., 25c.

1729-MATRICARIA GOLDEN BALI. More compact in growth than the white Fe. verfew, growing to a height of only 8 or 10 inches. Covered with bright yellow, densely double button-like blossoms. Pkt., 15c; 2 pkts., 25c. Nigella

\section{(Love-in-a-Mist)}

This is a compact free-flowering plant with finely cut foliage and curious looking seed pods. Very easy to grow.

1709-MIXED. Pkt., 10c; oz., 25c, postpaid.

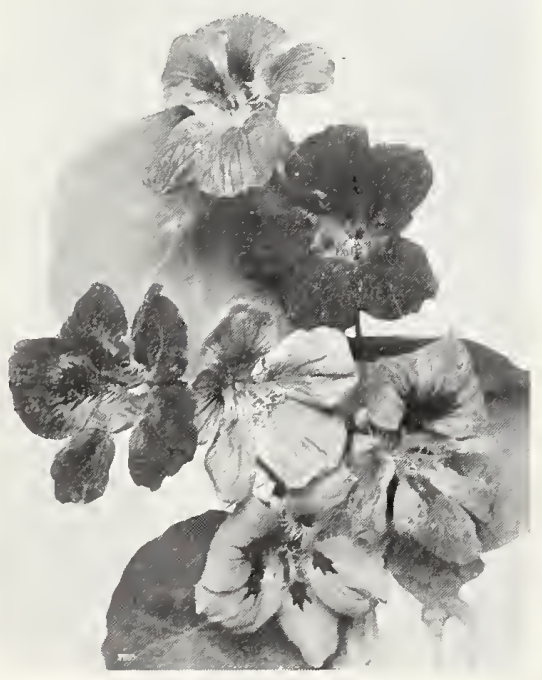

1488-Nasturtiums

\section{Nasturtiums}

1487-TALL MIXED. This is a fine mixture of the best trailing varieties. Pkt., 5c; oz., 20c; 1/4 lb., 50c; lb., \$1.50, postpaid.

1488-DWARF MIXED. These quick grow. ing plants are fine for edging and bedding and furnish a great abundance of flowers. Pkt., 5c; oz., 20c; 1/4 lb., 50c; lb., \$1.50; postvaid.

\section{Nicholson's Superb Flower Seed Collection}

Ten varieties of Flower Seeds for spring planting and especially adapted to Southern growing. Sure bloomers in a wide array of color.

Ten Regular 10c Packages Postpaid to You for Only

\section{$65 \mathrm{c}$}

1 Pkt. of-

Balsam, Double Flowering

Cosmos, Mixed Colors

Marigolds, Tall Double

Petunia, Mixed Colors

Portulaca, Mixed Colors

Phlox, Large Flowering Mixed

Scabiosa, Mixed Colors

Vinca or Periwinkle Mixed Colors

Zinnia, Double Giant Mixed

Morning Glory, Mixed Colors (No Changes Allowed in This Collection)

\section{Pansies}

Our seed is of the giant imported strains. For early spring blooming, sow seed in August and September, in soil enriched with leaf mold or well-decayed manure. Seed should not be covered more than four times the width of one seed. The soil should be pressed firmly over the seed and kept moist.

1491-CHOICE MIXED. Pkt., 10c; 3 pkts., $25 \mathrm{c} ;$ oz., \$1.50, postpaid.

1492-GIANT TRIMARDEAU MIXED. Pkt. $15 \mathrm{c} ; 2$ pkts., $25 \mathrm{c}$; oz., $\$ 2.25$, postpaid.

1493-NICHOLSON'S MAMMOTH FLOWERING MIXED. Pkt., 25c; 5 pkts., $\$ 1.00$ postpaid.

PERIWINKLE. See Vinca.

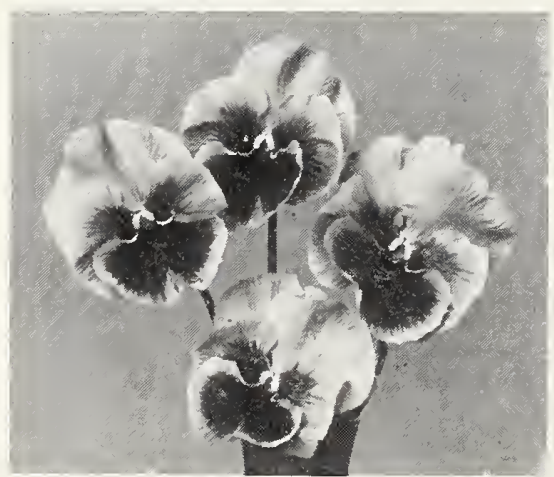

1493-Pansy

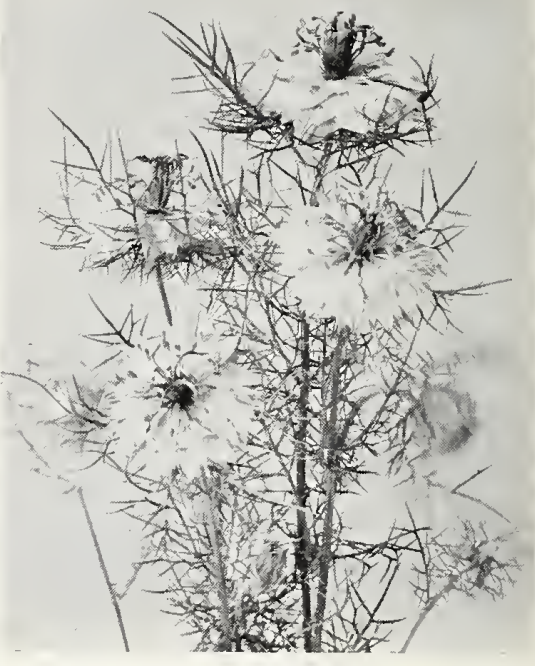

1709-Nigella

\section{Pentstemon}

\section{(Beard Tongue)}

A useful and attractive perennial that is treated as an annual. For mass bedding or planting in the border, the gardener will find this to be a worthwhile addition to his collection. It ranks with Petunias, Phlox, etc. The plants produce numerous upright stalks with little tendency to become ragged in appearance. The blossoms with their flaring lobes come in a wide range of colors and their light colored throats are beautifully spotted. Grow to a height of 2 feet and remain in bloom during a long period.

1525-PENTSTEMON GLOXINA. Mixed colors. Pkt., 15c : 2 for $25 \mathrm{c}$

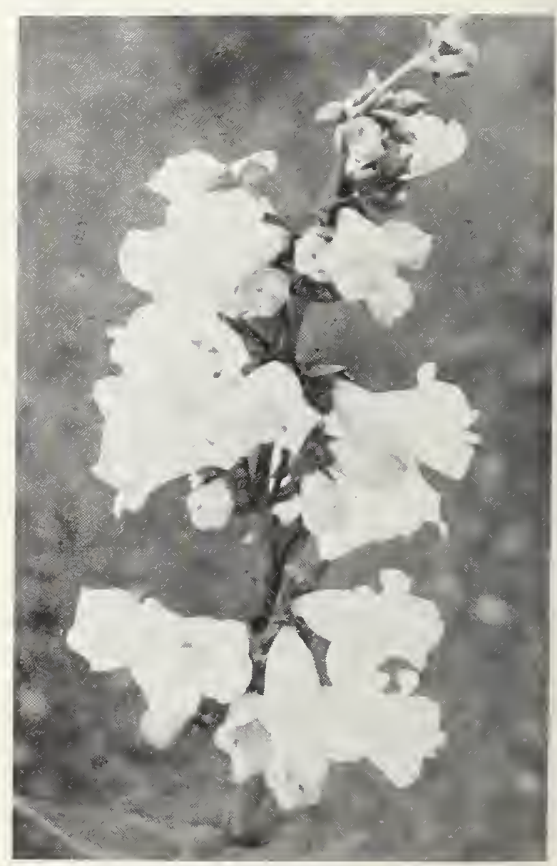

1525-Pentsemon Gloxina 


\section{Tested Seeds for}

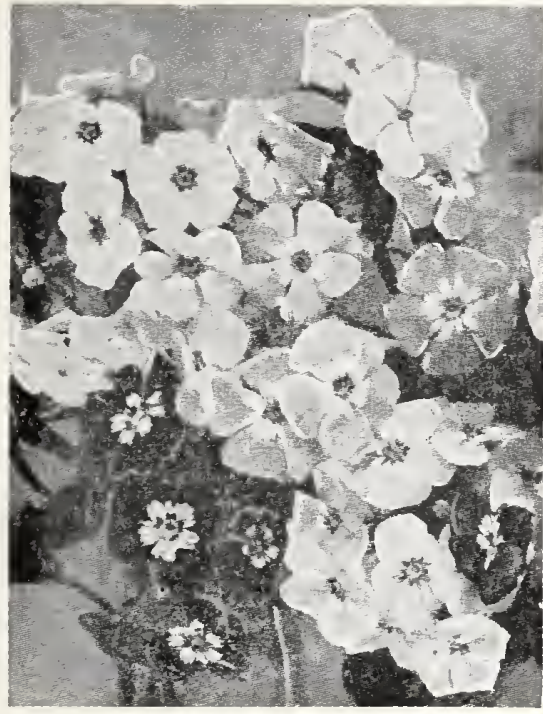

1506-Phlox-Mixed

\section{Phlox}

DRUMMONDI (Grandiflora). This hardy annual is unequaled for the magnificent display of brilliant colors when used in beds. Will thrive in most any soil. This flower is a native of Texas. Grows from 6 inches to 1 foot high.
1502-LILAC
1504-WHITE
1689 - VIOLET
1505 - SCARLET
1690-F LESH
1691-ROSE

Price of each, plst. 10c; 3 pkts., 25c; oz. $\$ 1.50$, postpaid.

1506-MIXED PHLOX. Pkt., 10c; 3 pkts., $25 \mathrm{c}$; oz., $\$ 1.25$, postpaid.

\section{Hardy Garden Pinks}

An old variety that is very popular for beds and borders. They produce flowers that afford quite a variety of colors. In fact, Pinks fit in nicely in any garden. Easily grown.

1507-DOUBLE MIXED. The flowers are rich in hue; very double, deep fringed petals. Colors vary from white to rose, lilac, carmine, crimson, scarlet, purple, brown, and almost black, spotted and striped. Mixed colors. Pkt., 10c; 3 pkts., 25c; 0z., 75c, postpaid.

1508-SINGLE MIXED. All colors. Pkt. I0c; 3 pkts., 25c; oz., 75c, postpaid.

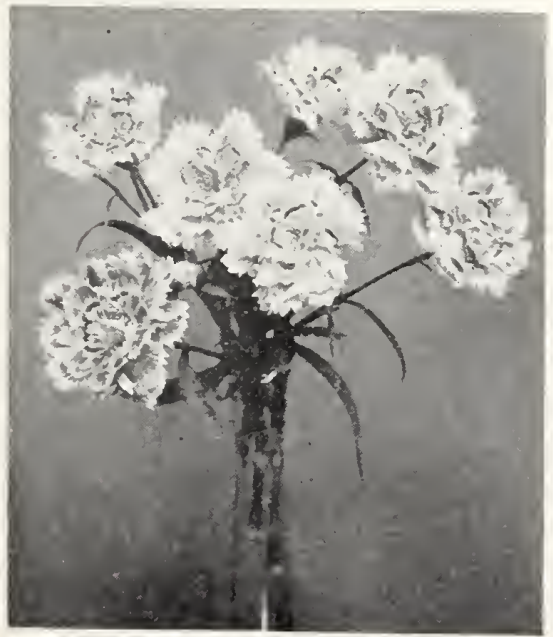

1507-Pinks-Double Mixed

\section{Portulaca-Rose Moss}

A very attractive, low-growing annual having a spreading habit; used in borders, beds and rockeries.

1500-SINGLE MIXED COLORS. Pkt., 10c; 3 pkts., 25c; oz., $\$ 1.00$, postpaid.

1501-DOUBLE MIXED COLORS. Pkt., $10 \mathrm{c} ; 3$ pkts., $25 \mathrm{c}$; oz., $\$ 2.50$, postpaid.

\section{Petunias}

These are among our most popular annuals on account of their ease of cultivation and freedom of blooming, succeeding almost everywhere, and giving a constant supply of beautiful flowers all through the season. The are also rood house plants, flowering freely in a sunny window, the balcony type being especially good for this purpose. Seed may be planted in the open ground early in the spring, or started indoors to be later transplanted.

1598-SILVER BLUE. A beautiful light blue shade. Is of the bedding type and excellent for beds of this one shade or makes a wonderful combination with General Dodds (red), or Rose of Heaven (pink). Petunia lovers should give this a trial without fail. Pkt., 25c: 5 for $\$ 1.00$, postpaid.

1494-ROSY MORN. Bears a great num ber of flowers which are a bright, rosy pink with white throat. The plants are small and compact and flower most freely. We recommend this variety very highly. Pkt., 10c 3 pkts., 25c; $1 / 1$ oz., $\$ 1.00$, postpaid.

1495-GIANT FLUFFY RUFFLES. These produce very large, handsome flowers of enormous size, with ruffled edges and a very rich variety of colors. Plants are strong and vigorous. If you appreciate giant Petunias, try these. Pkt., 25c; 5 pkts., $\$ 1.00$, postpaid.

1713-GIANTS OF CALIFORNIA. This Petunia is a worthy companion to our Giant Fluffy Ruffles. The flowers are very large, often 5 to 7 inches across, and embrace many beautiful shades and colors. Pkt., 25c 5 pkts., $\$ 1.00$, postpaid.

1496-S I N G L E S T R I P E D AND BLOTCHED. Pkt., 10c; 3 pkts., 25c; oz., $\$ 1.50$, postpaid.

1497-SINGLE MIXED. Pkt., 10c; 3 pkts., 25c; oz., \$1.00, postpaid.

1498-GENERAL DODDS. A very beautiful single Petunia. Color velvety blood-red Pkt., 10c: 3 pkts., 25c; oz., \$1.75, postpaid.

1499-ROSE OF HEAVEN. A dwarf, rosy pink variety; very beautiful. Pkt., 10c: 3 pkts., 25c; $1 / 1$ oz., $\$ 1.00$, postpaid.

1711-COUNTESS OF ELLESMERE. Rose, with white throat. Pkt., 10c; 3 pkts., 25c; oz., \$1.25, postpaid.

1712-VIOLACEA. Deep violet Pkt. 10 : 3 pkts., 25c; $1 / 4$ oz., $\$ 1.00$, postpaid.

1671-BALCONY ROSE, Pkt, 20c: 3 pkts 50 c, postpaid.

1672-BALCONY RED. Pkt., 20c; 3 pkts. 5 C. postpaid.

1673-BALCONY BLUE. Pkt., 20c; 3 pkts., $50 \mathrm{c}$, postpaid.

1674-BALCONY MIXED. Pkt., 15̌ ; pkts., 25c, postpaid.

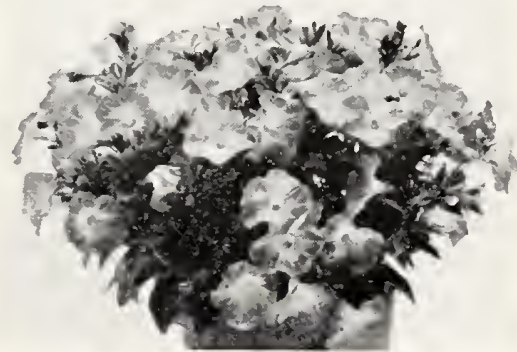

1498-Petunia-General Dodds

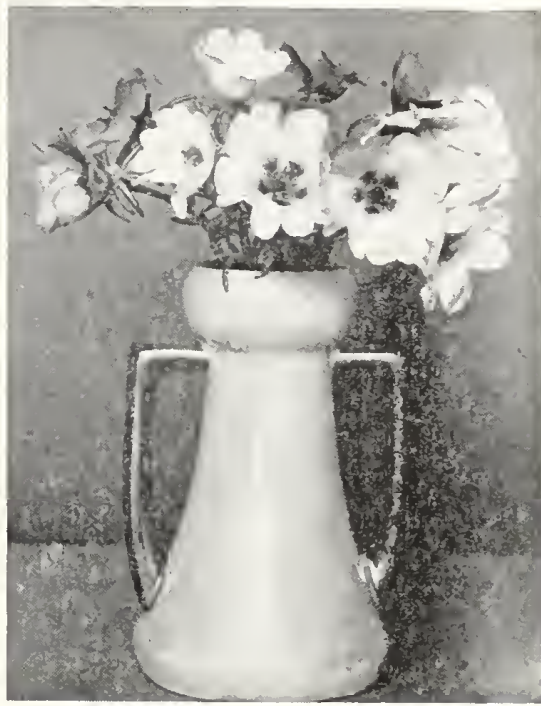

1500-Portulaca-Single Mixed Poppies

Both single and double varieties are very desirable for bed ding and borders. The flowers are remarkable for their large size, delicacy of tissue and wide range of dazzling colors. Can be sown in the spring or fall. We recommend September and October as the best time to sow, as Poppies stand a great deal of cold weather. A bed of Poppies and Larkspur mixed, planted in the late fall, will make a very beautiful display in the spring. DOUBLE VARIETIES

1722-PEONY-FLOWERED BRIGHT ROSE 1723-PEONY-FLOWERED CARDINAL RED.

1724-PEONY-FLOWERED CREAMY YELLOW.

1725-PEONY-FLOWERED WHITE. 1514-PEONY-FLOWERED AMERICAN

FLAG. White with scarlet margin.

1512-PEONY-FLOWERED MIXED.

1513-CARNATION-FLOWERED MIXED Price, all Double Poppies, pkt., 10c; 3 pkts. 25c; oz., 50c, postpaid.

CALIFORNIA POPPIES. See Esch scholtzia, Page

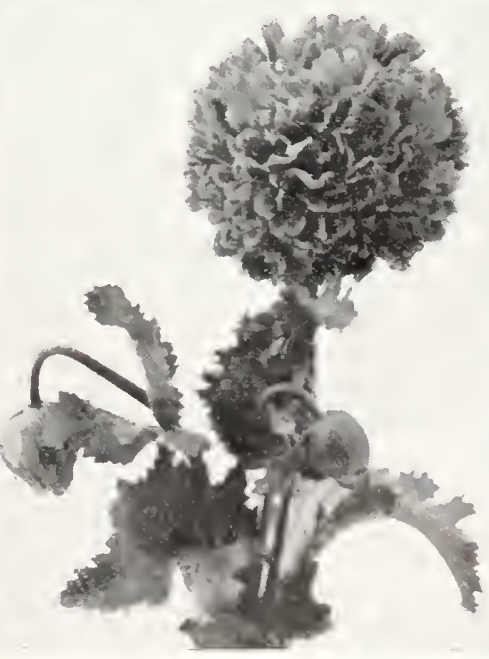

1513-Pcppy-Carnation Flowered 


\section{Robert Nicholson}

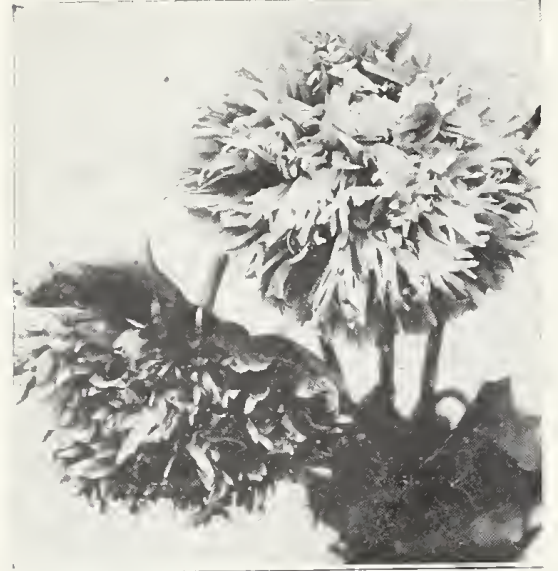

1512-Poppy-Peony Flowered Mixed

\section{Poppies}

(Continued)

SINGLE VARIETIES

1509-TULIP-FLOWERED SHIRLEY. The flowers are bright scarlet and tulip-shaped, with a black spot showing at the base of each petal. Pkt., 10c; 3 pkts., 25c; oz., 75c, postpaid.

1516-AMERICAN LEGION SHIRLEY. Brilliant orange-scarlet. Pkt., 10c; 3 pkts., $25 \mathrm{c}$; oz., $75 \mathrm{c}$, postpaid.

1511-SHIR LEY MIXED. Extra large flowers in many colors, and very beautiful. The petals are dainty, and appear to be made of crepe paper. Pkt., 10c; 3 pkts., 25c; oz., 50c, postpaid.

1510-1CELAND MIXED (Perennial). Are graceful, delicate flowers in many beautiful colors, the petals resembling crumpled tissue paper. Pkt., 10c; 3 pkts., 25c; oz., \$1.00, postpaid.

1515 -FLANDERS. This variety has become very popular since the World War. Our seeds are produced near the battle fields of France and Belgium, where these beautiful Poppies grow wild. Pkt., 10c; 3 pkts., 25c; oz., 50c, postpaid.

CALIFORNIA POPPIES. See Eschscholtzia,

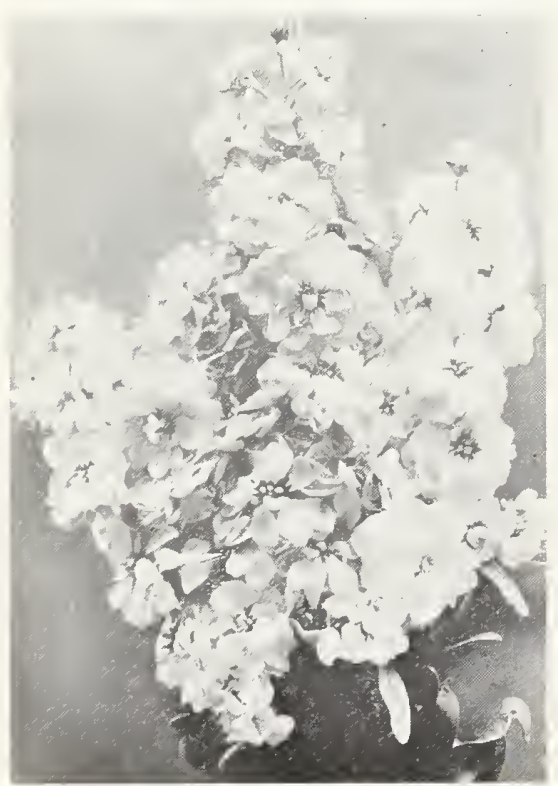

1518-Stocks-Mixed
Solanum

\section{(Jerusalem Cherry)}

This beautiful little plant can be easily grown from seed. It is one of the most satisfactory and ornamental pot or house plants. Beautiful dark green foliage covered with a mass of green and red cherry shaped fruit. The variety we have is an improved sort that is dwarf, branching habits; leaves small and oval shaped. Grows to a height of 12 inches and is very ornamental.

1730-CLEVELAND RED. Greatly improved over the old Jerusalem Cherry. Pkt., $15 \mathrm{c} ; 2$ pkts., $25 \mathrm{c}$.

\section{Salvia-Scarlet Sage}

This is considered the showiest bedding plant. With its brilliant color keeps the garden bright until fall.

1517-SPLENDENS. Pkt., 10c; 3 pkts., 25c; oz., $\$ 2.25$, postpaid.

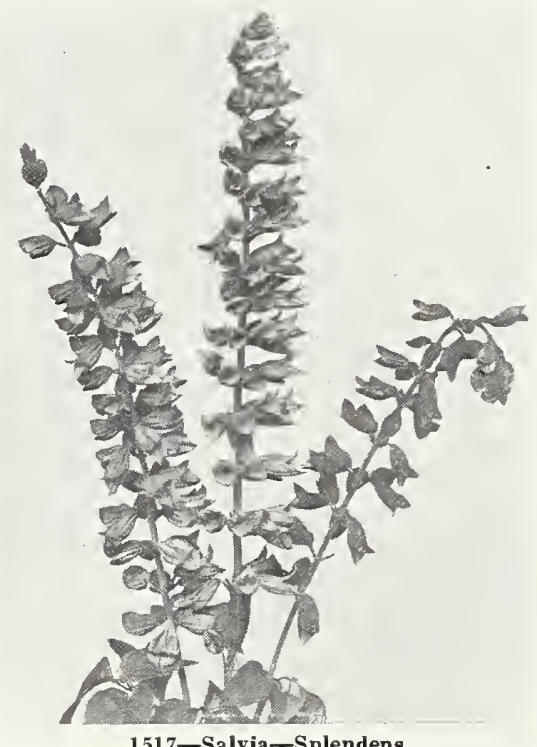

Scabiosa-Mourning Bride

t magnificent hardy annual of easy cultivation, blooming freely throughout the summer and fall. Stands our hot, dry summers better than almost any other flower. The flowers are large and very showy, growing on stalks $11 / 2$ to 2 feet high. They are very decorative for beds, and invaluable for cutting.

1692-BLACK PRINCE.

1693-CHERRY RED.

1694-FIERY SCARLET.

1695 -YELLOW.

1696-SNOWBALL.

1697-ROSE.

1698-LAVENDER.

Price, each of the above, pkt., 15c; 2 pkts. $25 \mathrm{c} ;$ oz., $\$ 1.00$, postpaid.

1519-MIXED SCAB1OSA. Pkt., 10c; 3 pkts., 25c; oz., 75c, postpaid.

\section{Scabiosa Caucasica}

This is the perennial Scabiosa, and is one of our most handsome border plants. Succeeds in any ordinary soil if well drained and in a sunny location, and should be in every garden where cut flowers are wanted. The flowers last a long time when cut and placed in water.

1699-NEW GIANT HYBRIDS (Isaac House Strain.) This is a very beautiful new strain, in which the flowers are extra large and of beautiful form, ranging in color from light azure-blue and lavender to deep blue and silvery white. Pkt., 25c; 5 pkts., \$1.00, postpaid.

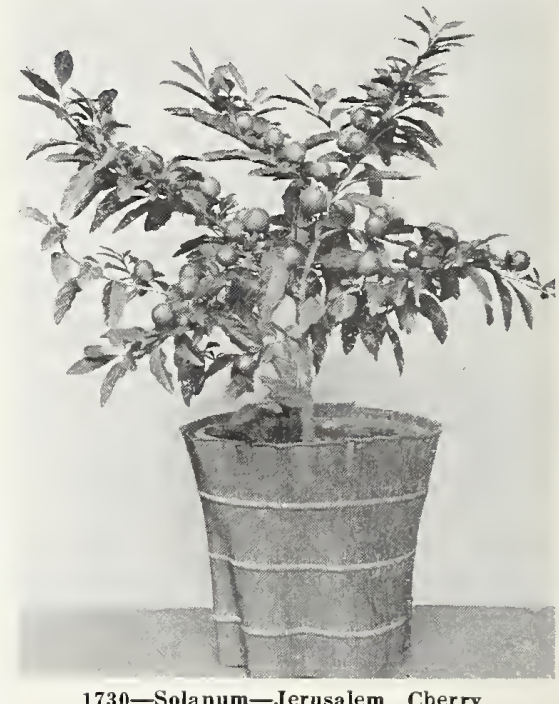

Salpiglossis-Painted Tongue

Attractive annuals. The blossoms are shaped somewhat like a Petunia, and each flower being veined with a glint of gold.

1710-MIXED SALPIGLOSSIS. Pkt., 10c; 3 pkts., 25c; oz., $\$ 1.00$, postpaid.

SNAPDRAGONS. See Antirrhinum.

\section{Stocks-Gilliflower}

MAMMOTH BRANCHING. The plant has a good habit of growth, with attractive glossy leaves, and the exceedingly fragrant flowers are borne on long, stiff stems.

1700-BRIGHT VIOLET.

1701-CANARY YELLOW.

1702-CRIMSON KING.

1703-MONT BLANC. White.

1704-PEACH BLOSSOM.

1705-PRESIDENT WILSON. Slate.

1706-ROSE QUEEN.

1518-M1XED.

Price, any of the above, pkt., 10c; 3 pkts., $25 \mathrm{c} ;$ oz., \$2.50, postpaid.

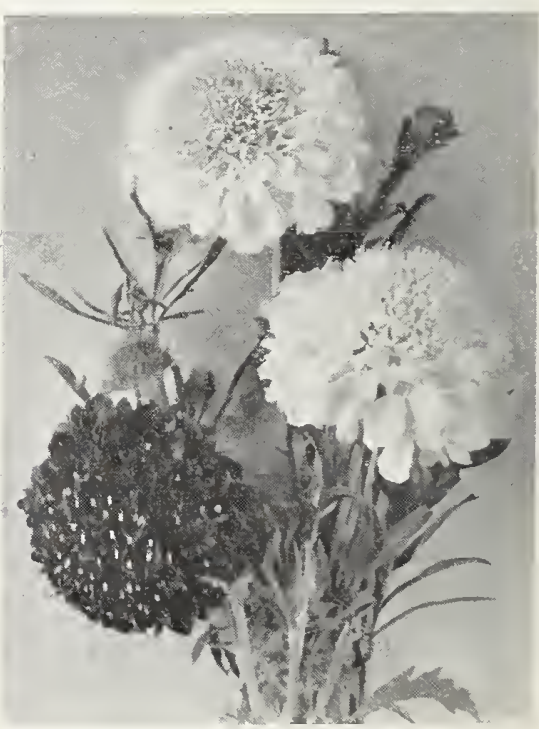

1519-Scabiosa-Mixed 


\section{Sunflower}

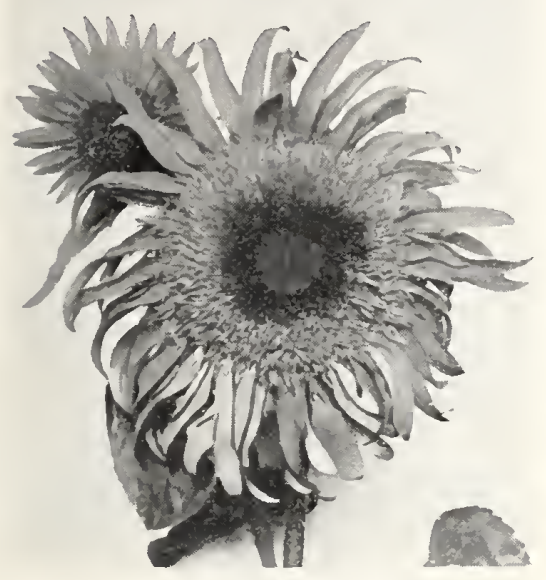

1546-Sunflower-Double

\section{Thalictrum-Meadow Rue}

The foliage is very finely divided, and is useful in making bouquets. Belongs to the buttercup family, and is very easy of cultivation.

1639-DIPTEROCARPUM. Very graceful sprays of flowers, elegantly arranged on stems 3 to 4 feet high, with blooms of a charming shade of violet-mauve, brightened by conspicuous lemon-yellow stamens and anthers. Pkt., 25c; 5 pkts., \$1.00, postpaid.

\section{Torenia}

1544-FOURNIERI A most charming small annual of fresh green foliage with funnel-shaped blooms very much resembling those of the snapdragon in shape. They are well adapted to our Southern climate and will flower abundantly throughout the late spring and early summer. Keep your plants well watered through the heat of the summer and at the first signs of fall you will enjoy another blooming period. The color of the bloom is a beautiful velvet blue with darker spots and yellow throat. Dandy for growing in beds, borders, flower boxes and hanging baskets. Suggest starting seeds indoors. 12 inches high. Pkt., 25c; 5 pkts., $\$ 1.00$, postpaid.

\section{Verbena}

No annual better known. Very desirable for massing in beds and flower boxes. 1551-SCARLET. 1554-PINK. 1552-WHITE. 1555-PURPLE. 1553-BLUE.

Price of each, pkt., 10c; 3 pkts., 25c; oz., $\$ 1.25$, postpaid.

1556-MIXED VARIETIES. Pkt., 10c: 3 pkts., 25c; oz., \$1.00, postpaid.

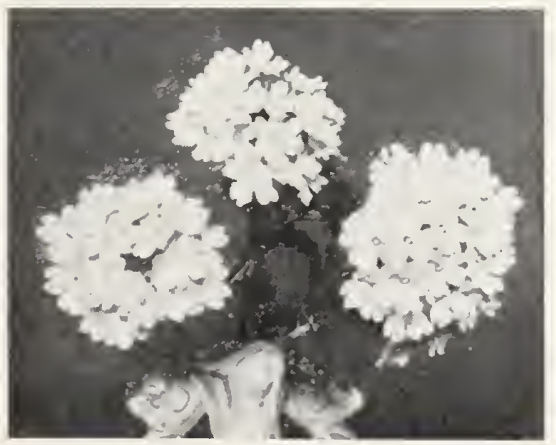

1554-Verbena-Pink
Easily grown and are valuable as a screen to hide unsightly places.

1545-MAMMOTH RUSSIAN. Grows 8 to 12 feet high, bearing flowers that often meas. ure 12 to 11 inches across. Interesting to watch their giant growth. Very useful to dry blooms and save seed to feed to your poultry. Oz., 5c; $1 / 4$ lb., $15 \mathrm{c}$; lb., 35c, postpaid.

1546-DOUBLE CHRYSANTHEMUM FLOWERED. Beautiful summer bloomers. Plants grow 6 to 8 feet tall, very attractive. Flowers large, with fringed petals, often 8 to 10 inches across. Pkt., 10c; 3 pkts., 25c; 0z. $75 c$, postpaid.

\section{Sweet Wivelsfield \\ (Dianthus)}

A member of the dianthus family. This remarkable new hybrid is quite distinct fiom the annual Sweet William. It is classed as a hardy annual with a wide variety of colors and a long blooming season. Magnificent as a bedding plant, also for borders, rock gardens and is an excellent and attractive cut flower.

1526-SWEET WIVELSFIELD. Mixed colors. Pkt., 25c; 5 pkts., $\$ 1.00$.

\section{Sweet William}

Beautiful flowering plant. Produces splendid effect in borders and beds with its rich and varied flowers.

1557-DOUBLE MiXeD (Perennial). Pkt., $10 \mathrm{c} ; 3$ pkts., 25c; oz., $\$ 1.00$, postpaid.

1559-SINGLE MIXED. (Annual). Begins blooming in July, when planted early in the spring. Pkt., 10c; 3 pkts., 25c; oz., 60c postpaid.

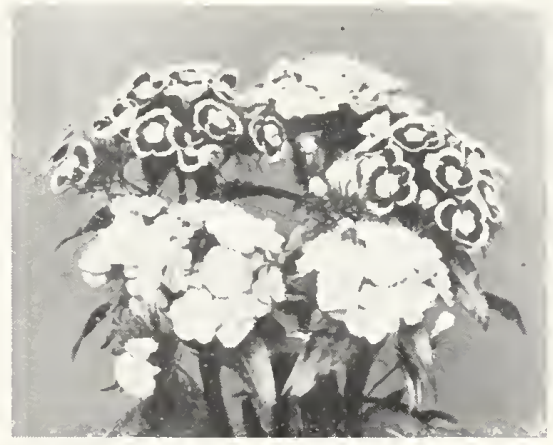

1557-Sweet William

\section{Wallflower}

This is one of the favorite garden flowers of England. Does exceptionally well in the South. The long, fragrant, terminal spikes are very conspicuous in beds and borders and are very useful in making bouquets. Will live through the winter if climate is mild. Plants grow about 18 inches high.

1670-MIXED COLORS. Pkt., 10c; 3 pkts., $25 \mathrm{c}$ : 0z., 50c.

\section{Viola}

1731-VIOLA CORNUTA (Tufted Pansies). Beautiful small perennials that are very similar to Pansies. While the blooms are not as large as those of the regular pansies, yet they bloon more freely and for a much longer period of time. Should be planted in every garden. Extra fine for bedding, borders, rockwork or for planting in mixed borders or beds. Pkt., 20c; 2 pkts.. 35 , postpaid.

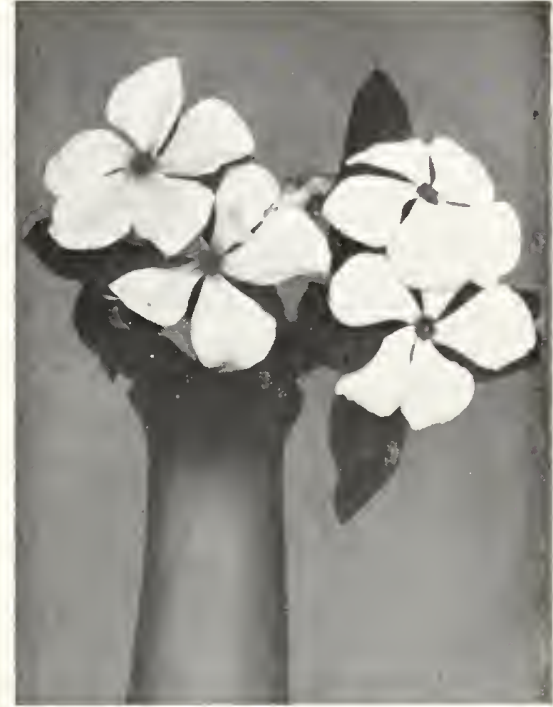

1560 -Vinca-Rosea

\section{Vinca-Periwinkle}

They stand the hot, dry weather better than almost any other flower.

1559-WHITE. Pkt., 10c; 3 pkts., 25c; 0z. $\$ 1.00$, postpaid.

1560-ROSEA. Pkt., 10c; 3 pkts., 25c; 0z., $\$ 1.00$, postpaid.

1561-WHITE WITII PINK EYE. Pkt. 10c: 3 pkts., 25c: oz., \$1.00, postpaid. $10 \mathrm{c}$; $1562-$ MIXED. All colors,
pkts., 25c; oz., \$1.00, postpaid.

\begin{tabular}{|ll|}
\hline \multicolumn{1}{|c|}{ FRAGRANT } & FLOWERS \\
Alyssum & Scabiosa \\
Centaurea & Stocks \\
Carnation & Sweet Peas \\
Heliotrope & Sweet William \\
Mignonette & Pinks \\
\hline
\end{tabular}

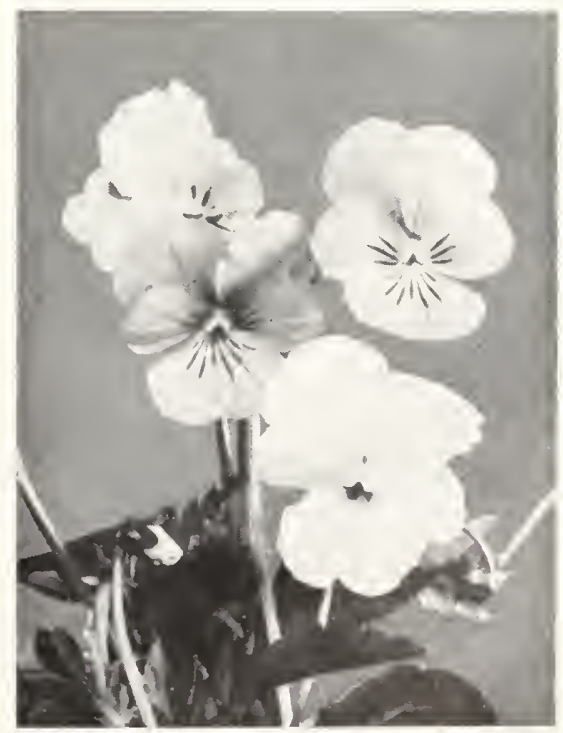

$1731-V$ iola 

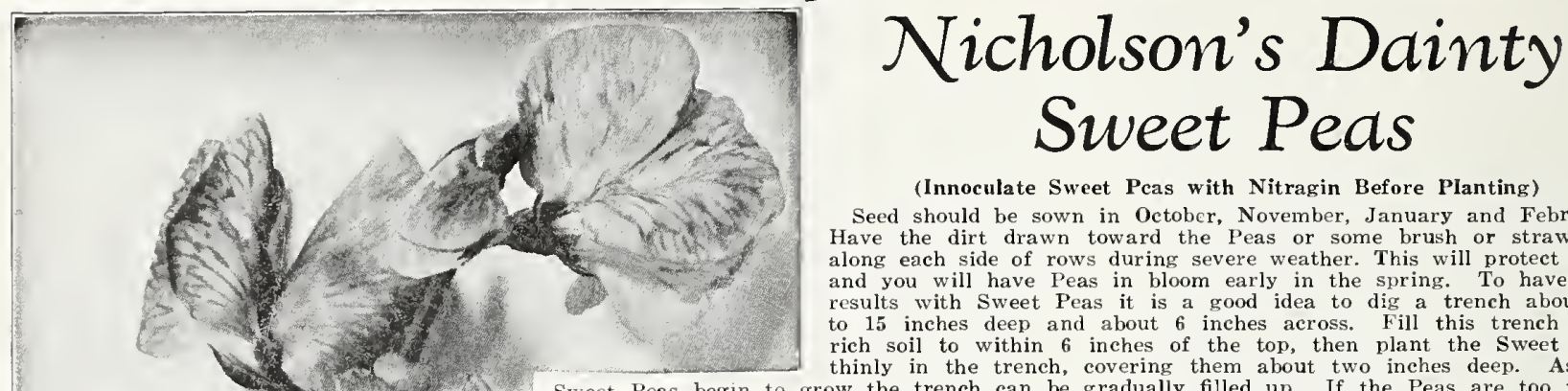

(Innoculate Sweet Peas with Nitragin Before Planting)

Seed should be sown in October, November, January and February. Have the dirt drawn toward the Peas or some brush or straw put along each side of rows during severe weather. This will protect them and you will have Peas in bloom early in the spring. To have best results with Sweet Peas it is a good idea to dig a trench about 10 to 15 inches deep and about 6 inches across. Fill this trench with rich soil to within 6 inches of the top, then plant the Sweet Peas thinly in the trench, covering them about two inches deep. As the Sweet Peas begin thin them out After they have a good start, a trellis of some kind should be used so that the Peas can have something to climb on. In order to have the Peas bloom a long time, the

Extra Early Flowering Spencer Sweet Peas

These varieties bloom very much earlier than ordinary Sweet Peas.

1619-SUPERIOR PINK. Rose-pink.

1620-AMETHYST. Royal purple.

1621-COLUMBIA. Pink and white.

1622-AVIATOR. Dazzling crimson-scarlet.

1623-MRS. KERR. Salmon.

1624-ALL WHITE Largest pure white.

1625-CREAM. Cream-pink.

1626-ELDORADO. Orange.

1627-FAIR MAID. Blush pink suffused

1628-NEW BLUE. Deep blue.

1629-SWEET LAVENDER. Pure lavender. Price, each of the above, pkt., $10 \mathrm{c} ; 3$ pkts., $25 \mathrm{c}$; oz., 50c; $1 / 2$ lb., \$1.50, postpaid.

1530-EXTRA EARLY SPENCER MIXED. Pkt., 10c; 3 pkts., 25c; oz., 40c; $1 / 4$ lb., $\$ 1.25$ tb., \$1.00, postpaid.

\section{Standard Spencer Sweet Peas}

These grow taller than the Extra Early Flowering varieties, and bloom later. 1531-MARY PICKFORD. Cream-pink : large, daintily colored flowers on long stems: very beautiful.

1532-BLUE MONARCH. Dark blue.

1533-BLANCHE FERRY. Red and white. 1534-FIERY CROSS. Orange-cerise.

1535-AUSTIN FREDERICK. Giant lavender.

1536-GOLDEN GLORY. Glowing orange. 1537-KING EDWARD. Crimson.

1538-KING MANUEL. Deep maroon.

1539-KING WHITE. Large waved white.

1540-ROSABELLE Light rose.

1541-ROYAL PURPLE. As named.

Price of the above, pkt., 10c; oz., 30c; ', lb., $\$ 1.00$; lb., $\$ 3.00$, postpaid.

1542-STANDARD SPENCER MIXED. Pkt., 10c; 0z,, 25c; 1/4 Ib., 75c; lb., \$2.25, postpaid.

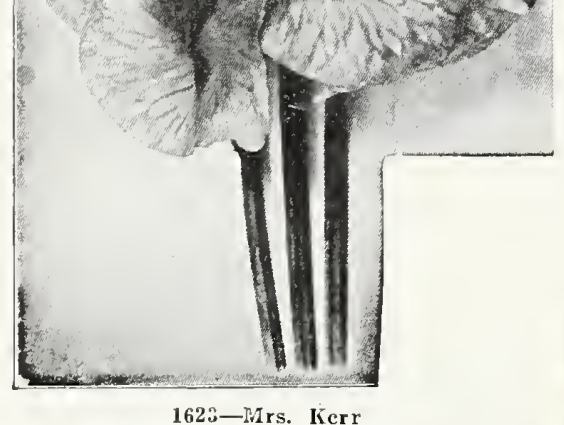

\section{Extra Early Long Stem Spencers}

These are the new Sweet Peas that have been developed for length of stem as well as beauty of bloom. The two varieties below have proven exceptionally satisfactory on test. EARLY PAL. An entirely new shade, introduced last season. It is a lively scintillant, pleasing, rich rose-carmine, in a combination of rose and crimson which holds the brightness and depth of color. Early Pal belongs to the new long-stemmed line which was recently introduced. Price, pkt., 25c; oz., 75c; $1 / 4$ lb., $\$ 2.00$; lb., $\$ 7.00$, postpaid.

EARLY APOLLO. This wonderful new variety belongs to the new long stemmed, and a soft salmon cerise in color. A most charming and appealing shade. Price, pkt. $25 \mathrm{c}$; oz., 75c; 1/1 lb., $\$ 2.00$; lb., $\$ 7.00$, postpaid.

\section{Eckford's Sweet Peas}

This is the old-fashioned type of Sweet Peas. Produces more flowers than the Spencers, but the flowers are a little smaller and less waved, and the stems are shorter.

1543-ECKFORD'S MIXED, Pkt. 10c: oz. $15 \mathrm{c}$; $1 / 4$ lb. 40c; lb., $\$ 1.25$, postpaid.

\begin{tabular}{|llcll|}
\hline & \multicolumn{3}{c|}{ FOR CUT FLOWERS } \\
Acroclinium & Calliopsis & Daisies & Marigolds & Scabiosa \\
Asters & Centaurea & Didiscus & Mignonette & Snapdragons \\
Brachycome & Chrysanthemum & Geum & Pinks & Stocks \\
Candytuft & Coreopsis & Gypsophila & Poppies & Sweet Peas \\
Carnation & Cosmus & Larkspur & Salvia & Zinnias \\
Calendula & Dahlias & Lupines & & \\
\hline
\end{tabular}

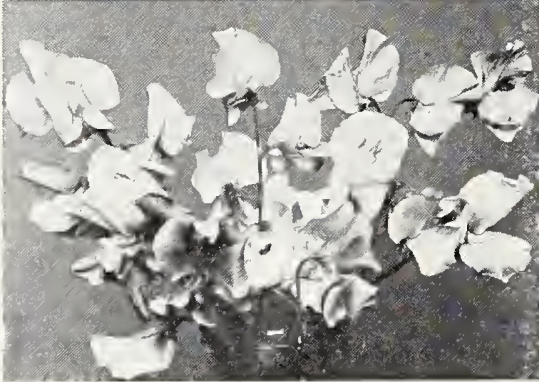

1542-Spencer Mixed

\section{Perennial Sweet Peas}

(Everlasting Sweet Pea.) These Peas, although lacking in fragrance, are very valuable because of the fact that they are perennials. The vine comes up from the roots every spring, growing vigorously, often from 8 to 10 feet, and produces a mass of beautiful flowers all during summer, which are fine for cut flowers.

1547-PINK BEAUTY, Pkt., 20c; 3 pkts. 50c. 1548-WHITE PEARL. Pkt., 20c; 3 pkts $50 \mathrm{c}$

1549-RED. Pkt., 20c; 3 pkts.. 50c.

1550-MIXED. All colors. Pkt., 10c; pkts., 25c: oz., 75c, postpaid.

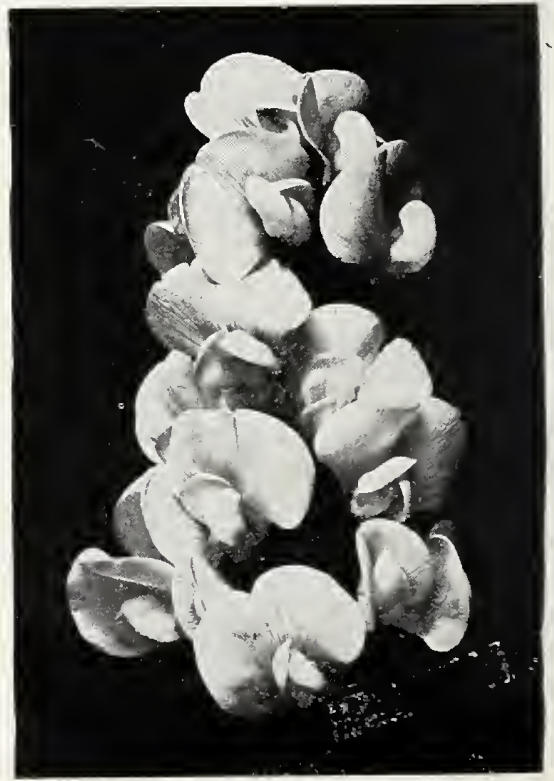

1547-Perennial Swcet Pea 


\section{Nicholson's Colorful Zinnias}

Without a doubt the most nopular and satisfactory for Southern flower gardens. They blom with greatest profusion from spring until killed by winter frosts. These beautiful annuals are widely known, but we have added new types that give us the most complete list of Zinnias in the South. Every sort to suit your taste, from the small Lilliputs to the monster bloomers. Please let us also call your attention to the new Scabious Flowered Zinnia. of which we have secured a supply this season for the first time.

Zinnias can be planted all during the spring and summer. Sow seed a quarter inch deep, no more thinning out the young plants from 12 to 14 inches apart. Dwarf types may be allowed to remain closer. To have a succession of flowers it is a good idea to make several sowings during the spring and summer.

\section{Nicholson's New Giants of California}

Last season we listed this new mammoth Zinnia for the first time and received many compliments, both as to color and size.

The blooms from the time they open are attractive, making them a good cut flower from early bud until they are in full bloom, when you will find them much larger than the old type giant Zinnia. A most pleasant surprise awaits anyone who plants the Nicholson's New Giants of California Zinnia.

1600-PURITY. A pure pleasing white

1601-MISS WILMOTT. A soft delicate pink.

1602-SCARLET GEM. A glowing scarlet that is attractive.

1603-LEMON QUEEN.

1605-ORANGE KING. Burnt-orange that is so much desired.

1606-VIOLET QUEEN. A glorious violet that is almost a purple.

1607-BRIGHTNESS. Bright deep-rose, one holds its color.

Price, separate colors listed above, pkt. $20 \mathrm{c} ; 3$ pkts., $50 \mathrm{c} ; 1 / 2$ oz., $\$ 1.75 ;$ oz., $\$ 3.00$, postpaid.

1610-NICHOLSON'S NEW GIANTS OF CALIFORNIA M1XED. A nicely proportioned mixture of colors and shades of this wonderful new large Zinnia. Pkt., 15c; 4 pkts., $50 \mathrm{c} ;$ oz., $\$ 2.00$, postpaid.

\section{Nicholson's Double Giant Zinnias}

1563-WHITE. 1564-LAVENDER. 1565-ORANGE. 1566-CRIMSON. 1567-SCARLET. 1568-BRONZE.

1569-PINK.

1570-PURPLE.

1571-YELLOW.

Price of each, pkt., 10c; 3 pkts. 25c; oz., $85 \mathrm{c}$, postpaid.

1572-DOUBLE GIANT MIXED. Pkt., 10c; 3 pkts., 25c; oz., 75c, postpaid.

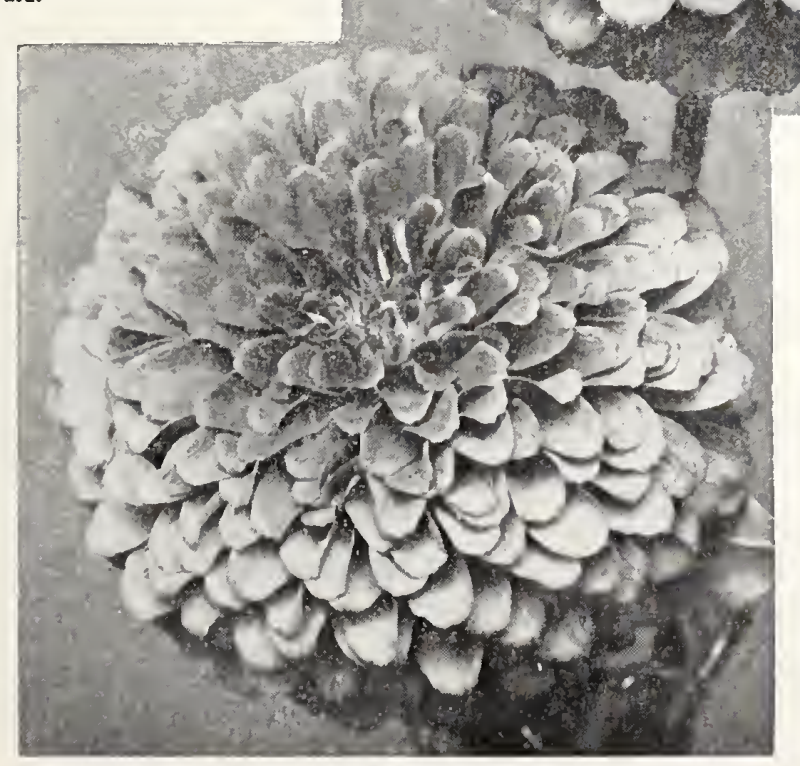

1602-New Giants of California

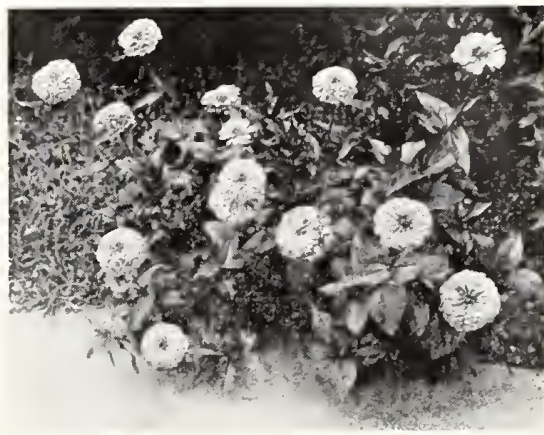

1678-Lilliputs-Double Zinnias

\section{Double Dahlia-Flowered Zinnias}

The flowers of this variety are of mam moth size and in form like a perfect decora tive dahlia.

$1573-E X Q U I S I T E$. One of the most pleas ing of the dahlia-flowered variety. Coloring. light rose with center dark rose

1574-PURPLE PRINCE. This is a beauti ful deep purple, with large, well formed flowers.

1575-OLD ROSE. A charming and beautiful variety of real old rose shade.

1576-ORIOLE. It is an immense orange and gold flower.

1577-CRIMSON MONARCH This is the largest of red shade varieties. Flowers often eight inches in diameter.

1578-CANARY IBIRD. A beautiful shade of primrose. Flowers large and hold their color well.

1632-GOLDEN DAWN. A beautiful gold en yellow of immense size and good form 1633-YOUTH. Pure rose.

1634-POLAR BEAR. A very large pur. hite.

Price, the above separate colors, pkt., 20c: 3 pkts., 50c: 1/ 0z. \$1.75: 0z.. \$3.00, post paid 1579-DAHLIA-FLOWERED MIXED. AI of the above and other colors in a splendid mixture. Pkt., 15c; 4 pkts., 50c; oz., $\$ 2.00$ postpaid.

\section{Nicholson's New Scabious Flowered Zinnias}

An attractive new Zinnia, entirely dif ferent to all other types. The plant reache a height of 36 to 40 inches and is an abund ant bloomer. The outer ring of the flower is formed of long petals, whereas the center shows many small flowers, which at firs sight are very much like Scabiosa. The bloom are rich in color and will prove a wonderfu addition to the Zinnia family. Be sure an order a trial package.

1583-MIXED COLORS. Many bi-color blooms, Pkt. 25c, 5 pkts $\$ 1.00$.

\section{Dwarf Double Zinnias}

These grow about 12 to 15 inches high. 1580-DWARF DOUBLE MIXED. Pkt. $10 \mathrm{c} ; 3$ pkts., $25 \mathrm{c}$; oz., $\$ 1.00$, postpaid.

\section{Cactus Flowered Zinnia}

They are robust and well branded, and will give a magnificent displav from early sirm mer until frost.

1582-CACTUS-FLOW. ERED MIXED. Pkt., 20c: 3 pkts., $50 \mathrm{c}$ : oz., $\$ 2.50$, pestpaid.

\section{Lilliput Double Zinnias}

This strain grows about one foot high and fairly bristles with small, globular flowers about one inch in diameter, in man beautiful colors. In bloom all the summer. 1675-GOLDEN.

1676-SCARLET

1677-SALMON-ROSE.

1686-WHITE.

1687-CANARY-YELLOW.

1688-PURPLE.

1678-LILLIPUT DOUBLE MIXED.

Price of each, pkt., 10c: 3 pkts., 25c: 02 $\$ 1.00$, postpaid. 


\section{Robert Nicholson}

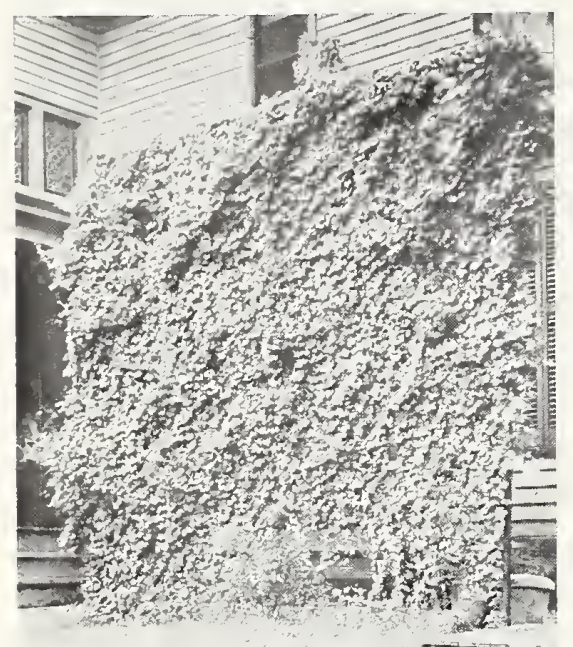

1650-Balsam Apple

\section{0-Balsam Apple}

An excellent climber bearing cream-colored flowers followed by yellow apple-shaped fruit, which, when ripe, opens, showing blood-red inside. A splendid climber. Pkt., 10c: pkts., 25c; oz., 50c, postpaid.

\section{1-Balsam Pear}

The fruit is pear-shaped, green, changing to bright red, and has a warty skin: when ripe it bursts and shows a brilliant interior of bright carmine. Pkt., 10c; 3 pkts., 25c; $0 z ., 50 c$, postpaid.

\section{2-Canary Bird Vine}

An excellent, quick-growing vine which produces canary colored flowers, climbing 15 to 20 feet; lasts well until frost. Pkt., 10c; 3 pkts., 25c; 0z., 50c, postpaid.

\section{6-Cardinal Climber}

A strong and rapid grower, reaching a height of 30 feet or more with fernlike foliage, producing, until frost, circular cardinalred flowers of about $11 / 2$ inches across. Pkt., 15c; 2 pkts., 25c; oz., \$1.25, postpaid.

\section{Cypress Vine}

A dainty clinber with a delicate dark green, fernlike foliage, producing many white and red, star-shaped blossoms. Seeds started early indoors make plants 20 feet high. For later sowing the seed should be soaked in water to hasten germination.

1653-WHITE.

1654-SCARLET.

1655-MIXED.

Price of each, pkt., 10c; 3 pkts., 25c; oz., $75 \mathrm{c}$, postpaid.

\section{Gourds}

Ornamental Gourds are very interesting climbers, producing a curious fruit. This oldfashioned climber usually runs 15 to 20 feet.

1663-EGG GOURD. Fruit white, like an

1664-DIPPER. Very useful for dipper.

1665-MIXED.

Price, any variety, pkt., 10c; 3 pkts., 25c: oz., 40c, pestpaid.

FOR SHADY PLACES

Snapdragons Daisies

Digitalis Pansies

\section{Nicholson's Vines, Climbers}

With their variance in color, their beauty of foliage and blossoms, their grace wherever used, vines frequently provide the finishing touches of any planting. Visualize the effect desired and train them accordingly to cover your walls and pilasters, your lattice or trellis, the pergola or laundry posts, the porch or portico, veranda or on the fence for shade, grace or flower and let them ramble in tbeir plentitude-objects of beauty and a pleasure to tbe planter.

\section{Humulus}

(JAPANESE HOP VINE)

A very rapid summer climber which in three or four weeks' time reaches a height of 20 feet or more. The foliage is luxuriant, making a dense covering. It is one of the best plants for shade and is very ornamental. It is grown primarily for its foliage as the small greenish-white flowers are quite small and inconspicuous.

1739-HUMULUS. (Japanese Hop Vine). Pkt., 10c; 3 pkts., 25c; oz., 75 c.

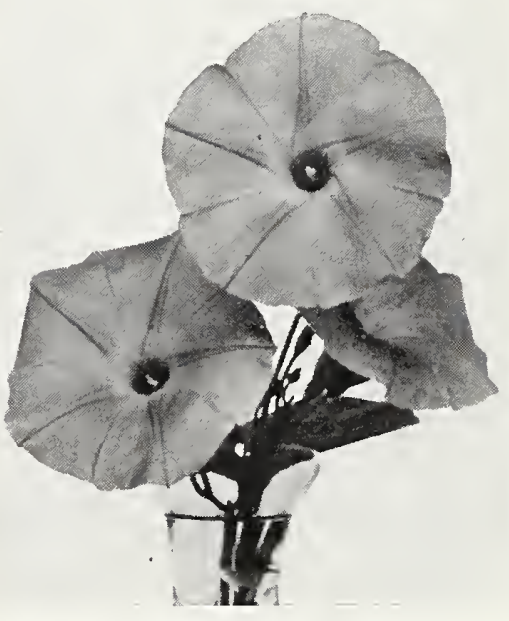

1659-Morning Glory

\section{Morning Glory}

One of the most popular outdoor vines. It produces various colored, delicate flowers, making this variety most attractive. As Morning Glory seed are very hard, we advise soaking them in lukewarm water for several hours before sowing.

1669-MEXICAN BLUE. A distinct variety with large purplish rose blooms, different from all other blues. Has large, forked, heavy, deen green leaves, making a most attractive vine. It is a perennial and the roots live from year to year in the southern part of Texas; some years as far north as Dallas. Suggest soaking seed overnight before planting. Pkt., 15c; 2 pkts., 25c; oz. $85 \mathrm{c}$, postpaid.

1658-IMPERIAL JAPANESE. Flowers are the largest of any Morning Glory, and of the finest coloring. They have various shades, solid colors and variegated mixed colors. Pkt., 10c; 3 pkts., 25c; oz., 50c, postpaid. 1659-HEAVENLY BLUE. Pkt., 10c; 3 pkts., $25 \mathrm{c}$ : oz., $\$ 1.00$, postpaid.

1660-BRAZILIAN. Flowers of pleasing rose color, borne very freely in large clusters. Pkt., 10c: 3 pkts, 25c; oz, 75c, postpaid.

1661-ROCHESTER. Very large flowers of a beautiful light blue, with an edge of silvery white. Pkt., 10c; 3 pkts., 25c; oz., 50c, postpaid.

\section{Jack Bean}

(DOLICHOS or HYACINTH BEAN)

1657-MIXED. A splendid climber with clusters of purple and white flowers. Grows to a height of 15 to 20 feet. Pkt., 10c; oz. 30c, postpaid.

\section{Moon Vine}

Moon Vines are among the most vigorous of all summer climbers. If planted in rich soil, in a sunny situation, and given plenty of water, the vines will attain a height of 75 feet. The large, dark green leaves are excellent for making shade.

1683-WHITE MOON VINE. Giant, pure white flowers, measuring 5 to 6 inches across. Blooms open nights and cloudy days. Pkt., 10c; 3 pkts., $25 \mathrm{c}$; oz., $75 \mathrm{c}$, postpaid.

1684-BLUE MOON VINE (Evening Glory). The flowers are violet-blue, and open in the evening. Pkt., 10c; 3 pkts., 25c; oz., 50s, postpaid.

\section{2-Scarlet Runner Bean}

A rapid growing climber. Has sprays of brilliant scarlet pea-sbaped blossoms. May be used as a snap or shell bean for eating purposes, or as an ornamental climber. Pkt., 10c; oz., 20c, postpaid.

\section{Thunbergia \\ (BLACK-EYED SUSAN)}

An elegant, graceful and slender climber with showy blooms. It will trail over the ground, forming a dense mat of foliage and blooms. Many beautiful colors with a jetblack center.

1740-MIXED COLORS. Pkt., 10c; 3 pkts.,

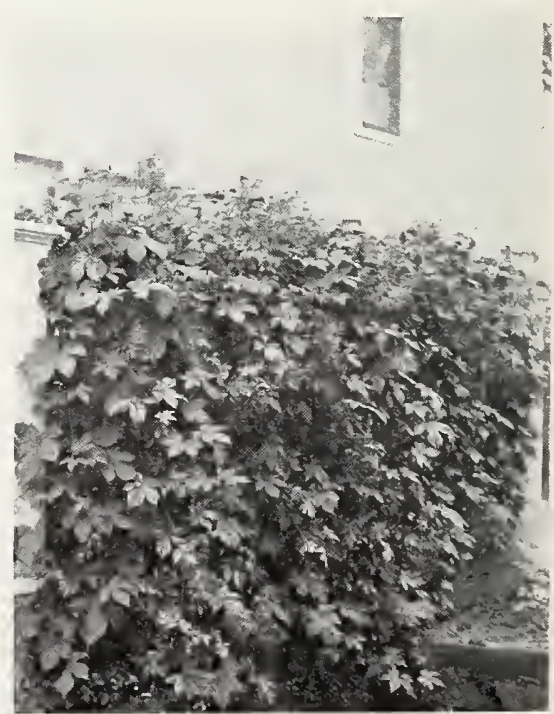

Humulus-Japanese Hop Vine 


\section{Tested Seeds for}

\section{Nicholson's Gorgeous Dahlias}

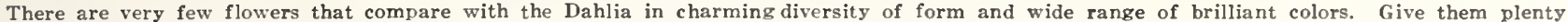

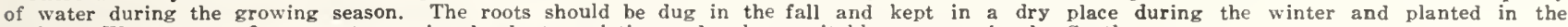
spring. We carry a fine assortment in the best varieties and colors, suitable to grow in the South.

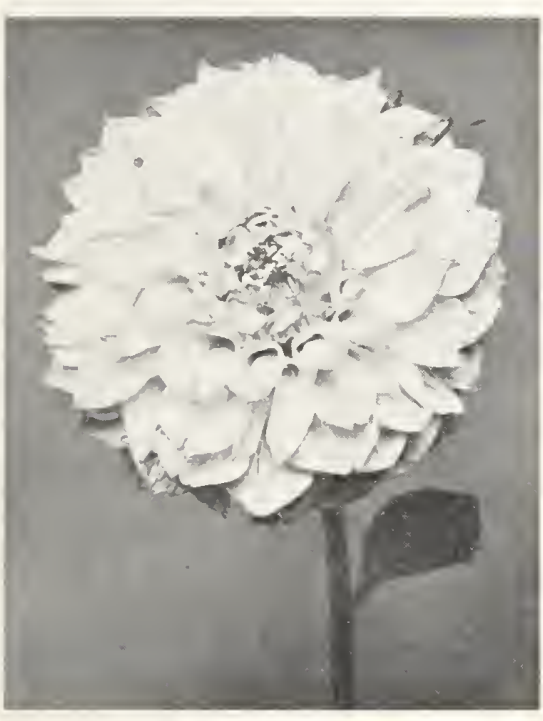

George Walters Dahlia

IIRS. CARL SALBACH. Lavender-pink California Decorative creation; exceptionally long stiff stems. $35 \mathrm{c}$ each, 3 for $\$ 1.00$.

MRS. CHAS. H. BRECK. Sulpbur-yellow blending to rose-pink and lilac, free-flowering. Hybrid Cactus development from Massachusetts. $35 \mathrm{c}$ each, 3 for $\$ 1.00$.

PRIDE OF CALIFORNIA. Mammoth "American Beauty" red. $35 \mathrm{c}$ each, 3 for $\$ 1.00$.

\section{Exceptional Dahlias}

MRS. ELMER O. DREW. Gigantic Hybrid Decorative from Massachusetts; long beautifully curling petals of velvety purplish. ma oon, six to eight inches in diameter. $\$ 1.00$ each.

SEQUOIA GIGANTEA Exceptional California creation of mammoth size, buttercup yellow with suggestion of red. Flowers six to nine inches in diameter, excellent stems. $75 \mathrm{c}$ each, 3 for $\$ 2.00$.

BASHFUL GIANT. Exquisite apricot with buff and gold tints, flowers six to nine inches across. $35 \mathrm{c}$ each, 3 for $\$ 1.00$

\section{DAHLIA COLLECTION No, 1}

One of each of these 6 Exceptional Dahlias for $\$ 3.00$ postpaid.
GEORGE WALTERS. Another giant California production, salmon-pink with blends of watermelon-red Hybrid Cactus. 50c each, 3 for $\$ 1.40$.

GLORY OF NEW HAVEN, Monstrous decorative creation from Connecticut of silvery lilac shading pinkish lavender. $50 \mathrm{c}$ each, 3 for $\$ 1.40$.

MRS. I. DE VkR WARNER. Most beautiful orchid-pink, of gigantic size, flowers from seven to ten inches across. Excellent strong, stiff stems: a phenomenal creation from Connecticut. 50c each, 3 for $\$ 1.40$.

\section{DAHLIA COLLECTION No. 2}

One each of Bashful Giant, George Walters and Mrs. I. De Ver Warner for $\$ 1.25$ postpaid

\section{Dahlias}

AMBER QUEEN. Miniature amber and apricot blend, ideal for cutting and table decoration. Exceptionally abundant flowering. $35 \mathrm{c}$ each, 3 for $\$ 1.00$.

CALIFORNIA ENCHANTRESS. Longstemmed lavender-pink Hybrid Cactus, excellent keeper. $35 \mathrm{c}$ each, 3 for $\$ 1.00$

ELIZABETH SLOCOMBE. Giant purplishgarnet from Connecticut. excellent habits, strong, vigorous grower; five to seven inches across. 35c each, 3 for $\$ 1.00$.

MRS. C. D. ANDERSON. Largest Hybrid Show Dahlia, crimson-purple, long stiff stems wonderful keeper. 35c each, 3 for $\$ 1.00$
MILLIONAIRE. Giant lavender witb white center. 35 c each, 3 for $\$ 1.00$

RENE CAYEUX Glowing crimson-red Cactus from France produces twenty-five to forty flowers per plant. $35 \mathrm{c}$ each, 3 for $\$ 1.00$. SOUV. DE GUSTAVE DOAZON. Large orange-red from France. $25 \mathrm{c}$ each, 5 for $\$ 1.00$.

DAHLIA COLLECTION No. 3 One each above 10 Dahlias, ten distinct colors, for $\$ 3.00$; any six for $\$ 2.00$ postpaid.

\section{Mexican Love Vine}

\section{ANTIGONON LEPTOPUS}

Also called Queen's Wreath. A beautiful perennial vine, with sprays of glowing pink flowers all summer. The vine dies in the winter and comes up again from the root in the spring. The roots sbould be protected with a mulch of straw or rotted leaves during the winter. Always plant on the south side of the house. This is one of the most beautiful climbers grown. Everyone wanting beautiful vines should plant some of these Mexican Love Vines. $35 \mathrm{c}$ each, or 3 for $\$ 1.00$, postpaid.

\section{Eupatorium}

EUPATORIUM COELESTINUM (Hardy Ageratum). A fine perennial, closely resembling the ageratum. Flowers mist blue, completely covering the plant from July until frost. The blooms keep well in water when cut, also valuable in floral pieces as a background and as a filler in vase an basketwork. Grows eighteen to twenty inches high, forming a well-rounded clump. Does best grown from root divisions-which we offer. Price, each 20c; 2 for $35 c$; doz., $\$ 1.75$.

\section{Tuberose}

SINGLE MEXICAN. This is the most satisfactory for the South. Very fragrant. Bulbs should be dug in the fall, and separated in the spring before planting. 50c per doz., 50 bulbs $\$ 1.75,100$ bulbs $\$ 3.00$, postpaid

\section{Dahlia Book}

\section{By F. F. Rockwell}

The Rockwell books are known for their helpful and interesting presentation of their subject. Discusses soil, fertilizer, planting, protection, storing, propagation, growing, and use of the Dahlia. 84 pages freely illustrated with drawings, postpaid for $\$ 1.00$

\section{Crinum Lily}

Sometimes called Angel Lily or Southern Lily, also Milk and Wine Lily. Produces cluster of five to nine large pinkish white flowers, with faint wine colored shadings on a tall stem. Flowers fragrant, blooming profusely all during the summer and fall. Fine for planting along fences or in centers of flower beds. Price medium sized bulbs, 25c each: large size, $50 \mathrm{c}$ each.

\section{German Iris}

Strong roots in purple, pink, white, lavender and yellow. 10c each; $\$ 1.00$ per dozen.

\section{Caladium}

Also known as Elephant's Ear. Medium size bulbs, 25c each; large bulbs, 50c each, postpaid.

\section{Rose Bushes}

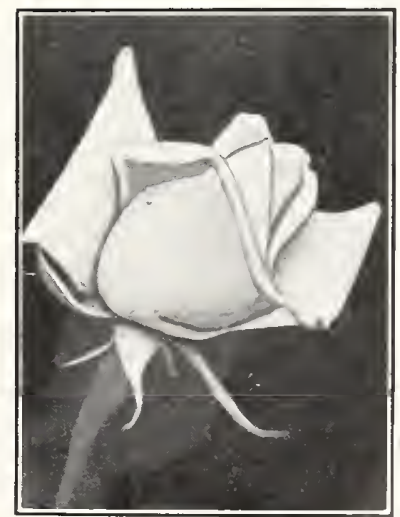

Strong, 2-year-old, field grown Roses, in all of the best varieties tbat we have found to give best results in Texas. We can gupply these during the months of December, January and February. If you will leave selection to us we will send you a good assortment of varieties. Have both bush and climbing varieties. However, if you want a list of varieties, we will be glad to send our illustrated Rose catalog. $40 \mathrm{c}$ each; $\$ 3.75$ per dozen, postpaid. 


\section{Nicholson's Superb Gladiolus $\begin{gathered}\text { See Back } \\ \text { Cover }\end{gathered}$}

Most Popular of All Summer-Flowering Bulbous Plants.

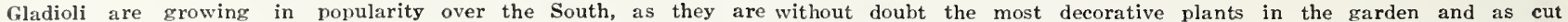

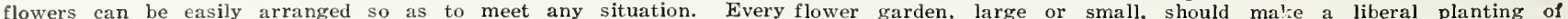

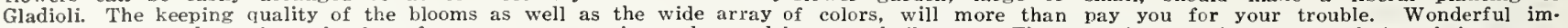

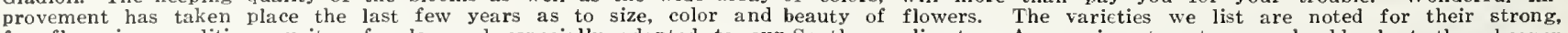

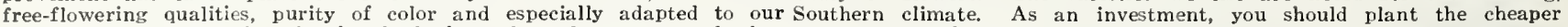
varieties of Gladioli by the hundred, but also plant some of the newer or named varieties.

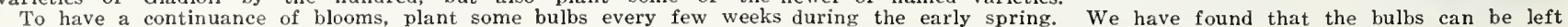

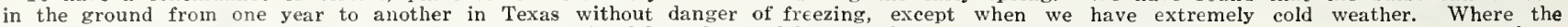

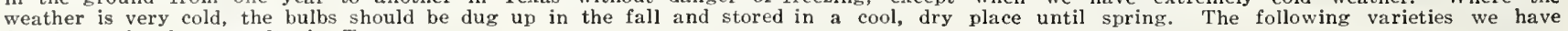
found to give best results in Texas:

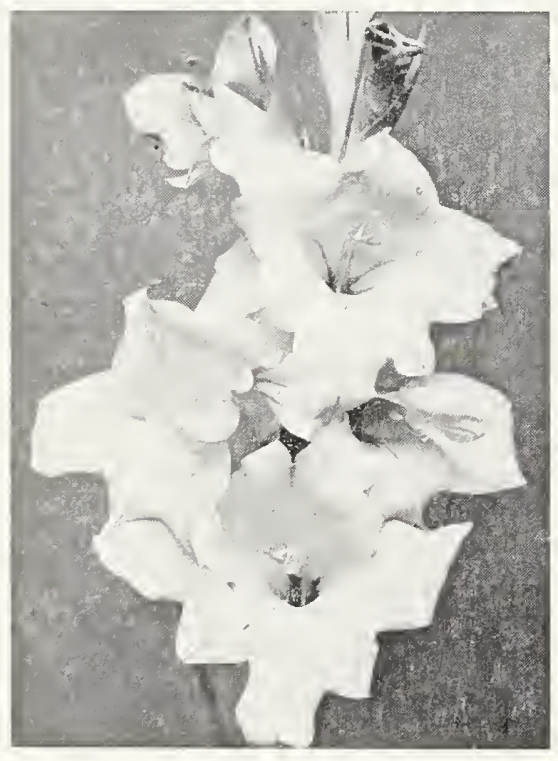

Gladiola-Halley
CHICAGO WHITE. A pure white with light lavender markings in throat. Price each $10 \mathrm{c}, 3$ for $25 \mathrm{c}$, dozen $75 \mathrm{c} ; 50$ bulbs $\$ 2.75$, 100 bulbs $\$ 5.00$.

FRANCIS KING. A beautiful large vermilion-scarlet. Price 10c each, 3 for $25 \mathrm{c}$ dozen $75 \mathrm{c} ; 50$ bulbs $\$ 2.75,100$ bulbs $\$ 5.00$.

MARY ALICE. Rose-pink with delicate throat markings of lavender-mauve. Price $10 \mathrm{c}$ each, dozen 85c; 50 bulbs $\$ 3.00,100$ bulbs $\$ 5.75$.

PANAMA. A large blooming and very beautiful pink. Price each $10 \mathrm{c}$, dozen $\$ 1.00$ 50 bulbs $\$ 3.00,100$ bulbs $\$ 5.75$.

MRS. FRANK PENDLETON. Flushed salmon-pink with maroon bloteh on lower petals. Very popular and a dandy variety. Price each 10c, dozen $\$ 1.00 ; 50$ bulbs $\$ 3.00 ; 100$ bulbs $\$ 5.75$.

\section{Nicholson's Beautiful Cannas}

Nothing is more attractive than a bed of Cannas. It is one of the most beauful and easily grown plants we know of.

YELLOW KING HUMBERT. $4 \mathrm{ft}$. Immense flowers of beautiful form, deep rich yellow, softly spotted and blotched with bright red. Dark green foliage. 15c cach; 2 for 25 ; $\$ 1.25$ per doz., postpaid.

HUNGARIA. $3^{1 / 2} \mathrm{ft}$. A very beautiful $\mathrm{rich}$ rose pink, the large flowers being horne on stout stems well above the foliage. Bluish green foliage. 15c cach; 2 for 25c; $\$ 1.25$ per doz., postpaid.

MADAME CROZY. $3 \frac{1}{2} \mathrm{ft}$. Flowers brilliant vermilion-scarlet, with narrow edge of golden yellow. 10c each; 2 for 15c; $80 \mathrm{c}$ per doz., postpaid.

THE PRESIDENT. \& $\mathrm{ft}$. This Canna is superior to any other red variety in he quality and also the quantity of bloom. Rich glowing scarlet, immense, firm flowers produced on strong, ercet stalks, well above the large, rich green foliage. $15 \mathrm{c}$ cach; 2 for $25 \mathrm{c}$; doz., $\$ 1.25$, postpaid.

WINTZER'S COLOSSAL. $5 \mathrm{ft}$. Without a doubt the largest flowered Canna yet produced. Flowers vivid scarlet, sometimes 8 inches across. 15c each; 2 for 25c; \$1.25 per doz., postpaid.

RICHARD WALLACE. Canary-yellow. $4 \mathrm{ft}$ Excellent bedder. Light green foliage: large, attractive trusses with 5 to 6 good sized blooms oven at a time. Color is light yellow, turning cream. The finest yellow we know of for bedding and one of the finest of all yellows. $15 \mathrm{c}$ each; 2 for $25 \mathrm{c}$; $\$ 1.35$ per doz., postpaid. KING HUMBERT. \& $\mathrm{ft}$. This is one of the grandest Cannas ever offered. The large heart-shaped leaves are purple-madder-brown over bronze. The plants are crowned with immense heads of orchid-like, velvety orange-scarlet, rose tinted and margined at the base: a combination of leaf and blossom incomparably beau. tiful. $15 \mathrm{c}$ each; 2 for $25 \mathrm{c} ; \$ 1.25$ per dozen, postpaid.

GOLDEN GATE. $4 \mathrm{ft}$. The flowers open almost pure gold, but soon become richly rayed with orange-crimson and apricot, centering to the throat. 15c cach; 2 for 25c; $\$ 1.25$ per dozen, postpaid.

FIERY CROSS. $4 \mathrm{ft}$. Color, vivid scarlet shading to crimson. So firm are the glistening petals that they do not wilt in the brightest sun. The foliage is a beau. tiful lustrous blue-grcen. It is free from blight and disease. 15c each; 2 for 25c; $\$ 1.25$ per dozen, postpaid.

FLORENCE VAUGHAN. Grows about 4 feet high. Flowers beautiful golden yellow, thickly dotted with crimson. 10c cach; 2 for 15c; 80c per lozen, postpaid.

CITY OF PORTLAND. 31/ ft. The flowers are of the largest size, borne on heavy trusses. The color is a glowing shade of pink. The foliage is substantial and strong, of rich green color and free from defects. Price 20c each; 2 for $35 \mathrm{c}$; $\$ 1.75$ per dozen, postpaid.
HALLEY. An early blooming, delicate salmon-pink. Price each $10 \mathrm{c}, 3$ for $25 c$, dozen $75 c$; 50 bulbs $\$ 2.75,100$ bulbs $\$ 5.00$.

CRESCENT QUEEN. Very dark wine-red. Large blooms. Irice each 10c, dozen $\$ 1.00$; 50 bulbs $\$ 3.25,100$ bulbs $\$ 6.00$.

OD1N. Very large salmon bloom with dark blotches. Price cach $10 \mathrm{c}$, dozen $\$ 1.00 ; 50$ bulbs $\$ 3.25,100$ bulbs $\$ 6.00$.

SOUVENIR. A clear, bright daffodil-yellow, very pretty. Price each 10c, dozen $\$ 1.00 ; 50$ bulbs $\$ 3.00,100$ bulbs $\$ 5.75$.

AMERICA. A beautiful soft lavender-pink. Price, each, 10c, 3 for $25 c$, dozen $75 c ; 50$ bulbs $\$ 2.75,100$ bulbs $\$ 5.00$.

BARON J. HULOT. The most popular purple with well-placed blooms, a variety that seems to please critical growers. Price each $10 \mathrm{c}$, dozen $\$ 1.00 ; 50$ bulbs $\$ 3.50$.

N1CHOLSON'S POPULAR MIXTURE. A most pleasing mixture that will please and should be planted in quantity. A wide array of color that will brighten up your garden. Price, dozen, 60c; 50 bulbs, $\$ 2.35,100$ bulbs $\$ 4.50$.

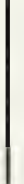

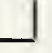
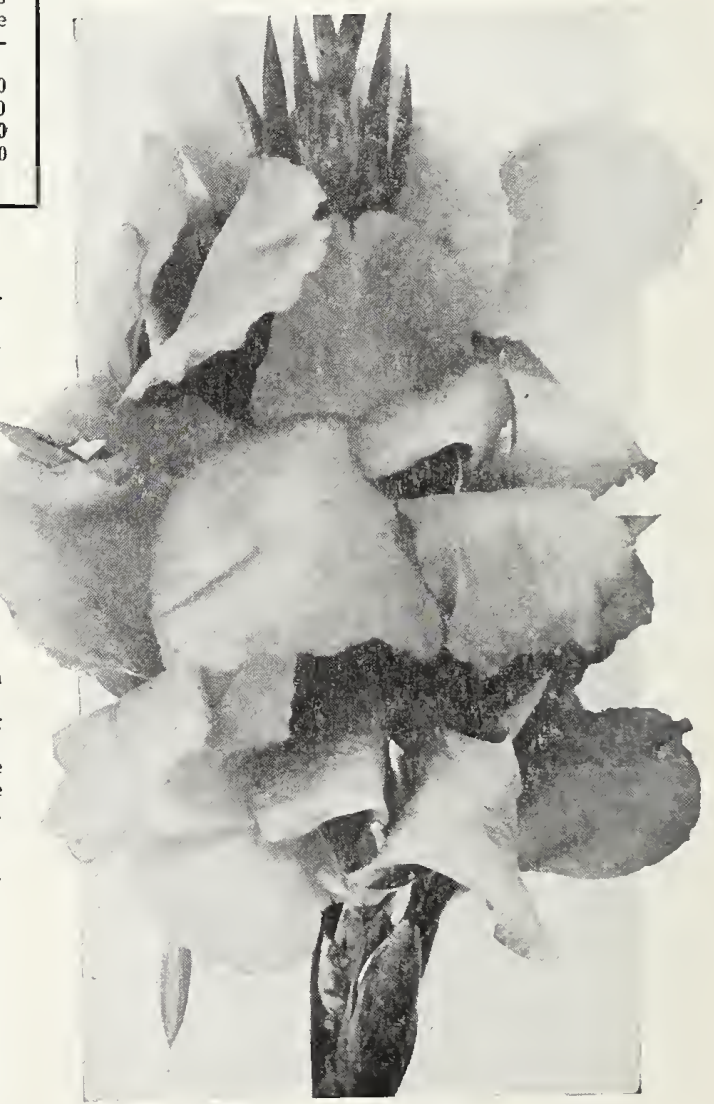

Canna-City of Portland 
There have been many reasons advanced for the planting of a home garden, but it has always been our humble opinion that economy and thrift , the contention by several occurrences this year. You have heard it said and advertised that you "can buy vegetables cheaper than you can raise them". This is not a fact. Why would the American National Red Cross buy garden seed as a first move to aid destitute families of the drouth areas during the spring of 1931? They know from a half century of experience that the families so helped would be able to produce enough to feed themselves for many months to come, which has proven to be a fact and brings to mind the following lines: "The farmers' present position"-Owes less at the bank than a year ago; has a big feed crop fur his livestock; living at home in practice as well as theory; he is better off than the average city man and only needs to be left alone.

Owing to the contemplated cut in cotton acreages for the coming season, it is our prophecy that many farmers will go back to our old dependable system of farming. Naturally this spare land will be made to produce feed crops. If you do not own a cow, buy one or more use ample milk for your family and sell your surplus. Buy 100 hens or more, use eggs for home consumption and sell your surplus. Buy at least two hogs for a start and raise a good part of your meat. Can or dry your surplus vegetables and fruits. Your reply to these suggestions is perhaps that you are unable to enter into a program of this kind without money. We will frankly state that after hearing many large and small bankers talk, that it is the one and only program on which they will make you a loan this coming season.

Your County Agent has a good program for your particular section of the State. Talk to him and explain your problems.

\section{HOME GARDEN SUGGESTIONS}

1. SELECTION OF PLOT. When possible, select a plot containing a good deep, rich and mellow soil that can be broken and handled easily. A soil of fine texture similar to a sandy loam is ideal.

2. PREPARATION OF SOIL. Spade or plow up the soil, then rake or harrow until all lumps have been broken thoroughly and soil rendered mellow. An application of well rotted barnyard manure or pulverized and sterilized sheep manure will improve the texture and increase the fertility of the soil. Heavy soils can be loosened by applying a layer of ashes or sand. When the soil is too loose and does not hold enough moisture an application of peat moss will give wonderful results; it also adds humus which is so necessary to any soil.

3. SEED. Plant only seed of high germination and purity and purchased from a reliable source. Plant "Nicholson's Tested Seeds."

4. PLANTING. Your utmost care and attention should be given to planting, as a great deal of your success will depend on how you plant. The denth to which most seed is sown is judged by the size of seed, texture and average moisture content of soil. The larger the seed the deeper it will have to be planted, the smaller the seed the shallower it is sown. As a general rule, most seeds are covered with soil not more than three or four times the thickness of seed.

5. CULTIVATION AND CARE. Keep grass and weeds cleaned out and never let them go to seed. Keep top soil near plants stirred and loose to conserve moisture for the plants use.

6. WATERING ARTIFICIALLY. The best time to water is carly in the morning or late in the afternoon.

\section{Nicholson's Vegetable Planting Schedule}

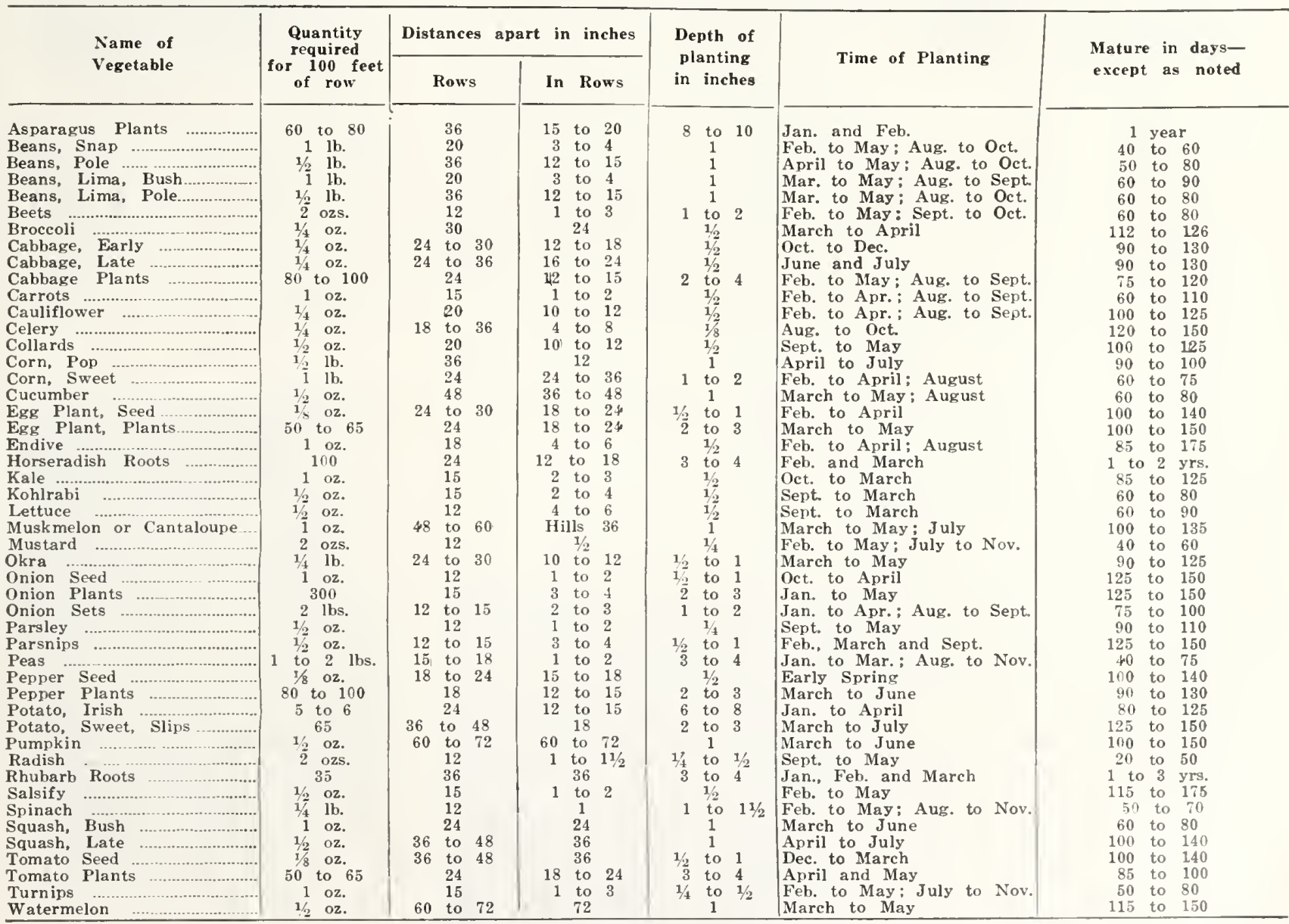

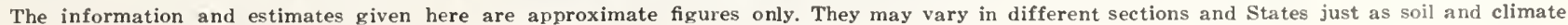
vary. Often one gardener, to insure a full stand, will sow his seed more generously than his neighbor. 


\section{Robert Nicholson}

\section{Nicholson's Tested Garden Seed}

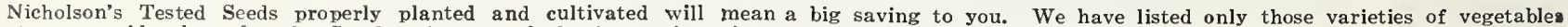

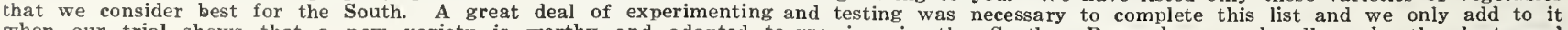

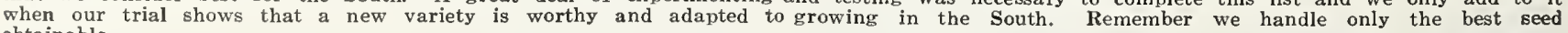
obtainable.

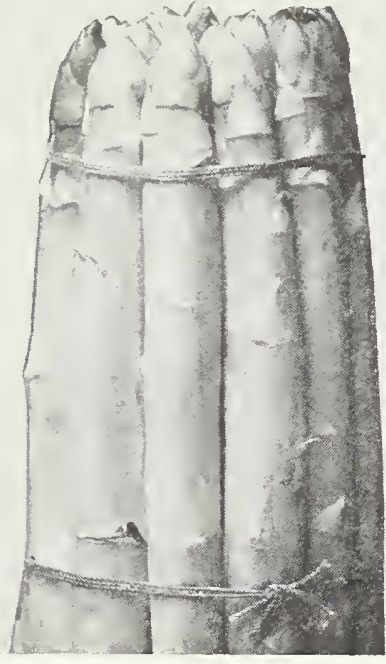

90-Asparagus-Palmetto

\section{Asparagus}

(SEED AND ROOTS)

A most delicious vegetable that is growing in popularity for home growing. You can have a fine bed of Asparagus by planting our Washington or Palmetto roots. If roots are planted this spring you can cut from the bed next spring. With seed, a year longer is necessary.

CULTURE. Sow seed thinly in drills one foot apart early in the spring or fall, after soaking seed in warm water for an hour. Use a rich, well worked light soil and, when well up, thin plants to one inch apart and cultivate often until the plants are a year old.

Transplant or set out the roots in permanent bed, using the richest soil you have, thoroughly prepared and worked very deep. Set roots 4 inches deep and 18 inches apart in rows 4 to 6 feet apart. Cultivate frequently until plants meet in the rows. Use plenty of stable manure or other fertilizer on bed before and after setting out roots, mixing well into soil. A sprinkling of salt and a dressing of fresh wood and manure after plants die down each year is advisable.

90-PALMETTO ASPARAGUS SEED. An early maturing and prolific variety that is considered best for the South. It is uniform in growth, also easily grown from seed. Pkt. $10 \mathrm{c}$, oz. 15c, 1/4 lb. 25c, lb. $75 \mathrm{c}, 5 \mathrm{lbs}$. $\$ 3.50$, postpaid.

PALMETTO ASPARAGUS ROOTS. Large, strong, healthy roots. Dozen, 35c; 50 roots, $\$ 1.00 ; 100$ roots, $\$ 1.75$, postpaid.

91-WASHINGTON ASPARAGUS SEED. Classed as a rust-resistant type and large in size. A variety strongly favored by commercial gardeners. Greatly improved over the older varieties. Pkt. 10c, oz. 20c, $1 / 4 \mathrm{lb}$. 50c, lb. $\$ 1.50$, postpaid.

WASHINGTON ASPARAGUS ROOTS. Many of our customers who have had an Asparagus bed for years are now planting the Washington variety. Strong, healthy roots of good planting size. Dozen 35c, 50 roots $\$ 1.25,100$ roots $\$ 2.25$ postpaid.

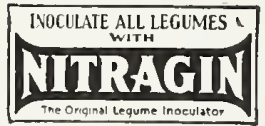

\section{Nicholson's Green Pod Bush Beans}

Clase de Mata Baja y Vaina Verda One pound plants 75 to 100 feet of row.

100-NICHOLSON'S GIANT STRINGLESS GREEN POD. This splendid stringless variety of Bean is of the finest quality and very early. The pods are oval-round, bright green, tender, crisp and about $4 \frac{1}{2}$ inches long. Is especially recommended to market gardeners on account of its earliness and superior quality Pkt, 10c: 1/2 lb, 20c: lb, 40c:-2 lbs., 75c; 5 lbs., $\$ 1.50$, postpaid. Not prepaid, 20 lbs. $\$ 3.25 ; 50$ lbs., $\$ 7.50 ; 100$ lbs., $\$ 14.00$.

101-BURPEE'S STRINGLESS GREEN POD. Absolutely stringless green pod; fine quality. Round pods, matures early and is very prolific. Specially recommended for home garden. Pkt., 10c; 1/2 lb., 20c; lb., 40c; 2 lbs., $75 \mathrm{c}$; 5 lbs., $\$ 1.50$, postpaid. Not prepaid, 20 lbs., $\$ 3.25 ; 50$ lbs., $\$ 7.50 ; 100$ lbs., $\$ 14.00$.

102-NICHOLSON'S EARLY ROUND POD RED VALENTINE Largely planted by gardeners because the plants will stand more adverse weather conditions than other Bush Beans. Pkt., 10c; 1/2 lb., 20c; lb., 40c; 2 lbs. $75 \mathrm{c} ; 5 \mathrm{lbs}$., $\$ 1.50$, postpaid. Not prepaid, 20 lbs., \$3.25; 50 lbs., $\$ 7.50 ; 100$ lbs., $\$ 14.00$.

103-TENNESSEE GREEN POD. Very prolific and one of the earliest Beans there is. Matures a week or ten days earlier than most other varieties. Pods long, flat, bright green. Pkt., 10c: 1/2 lb., 20c; 1b., 40c; 2 lbs., 75c; 5 lbs., \$1.50, postpaid. Not prepaid, 20 lbs., $\$ 3.25 ; 50$ lbs., $\$ 7.50 ; 100$ lbs., $\$ 14.00$.

104-EARLY REFUGEE or 1000 to 1 . One of the second early sorts. Pods are round. Bush very robust, great bearer, and withstands adverse weather conditions. Pkt., 10c: $1 / 2$ lb., 20c: 1b., 40c; 2 lbs., $75 \mathrm{c}$; 5 lbs., $\$ 1.50$, postpaid. Not prepaid, 20 lbs., $\$ 3.25 ; 50$ lbs. $\$ 7.50 ; 100$ lbs., $\$ 14.00$.

106-BOUNTIFUL. Has long pods of a light green color, tender and stringless. One of the best Beans to grow for snaps, a splendid sort for the market. Pkt., 10c; $1 / 2$ lb., $20 \mathrm{c}$; lb., 40c; 2 lbs., $75 \mathrm{c}$; 5 lbs., $\$ 1.50$, postpaid. Not prepaid, 20 lbs., \$3.25; $50 \mathrm{lbs}$., $\$ 7.50 ; 100$ lbs., $\$ 14.00$.

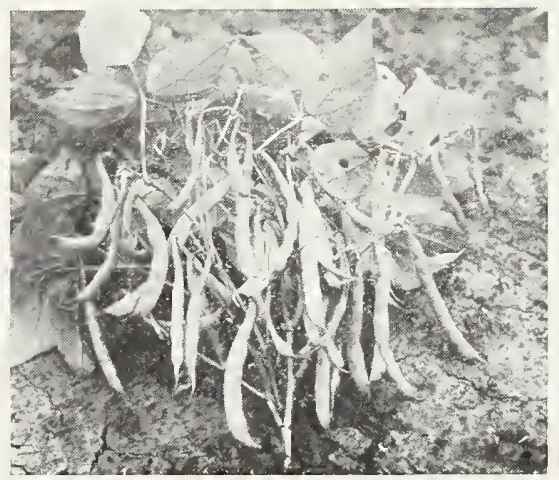

104-Early Refugee

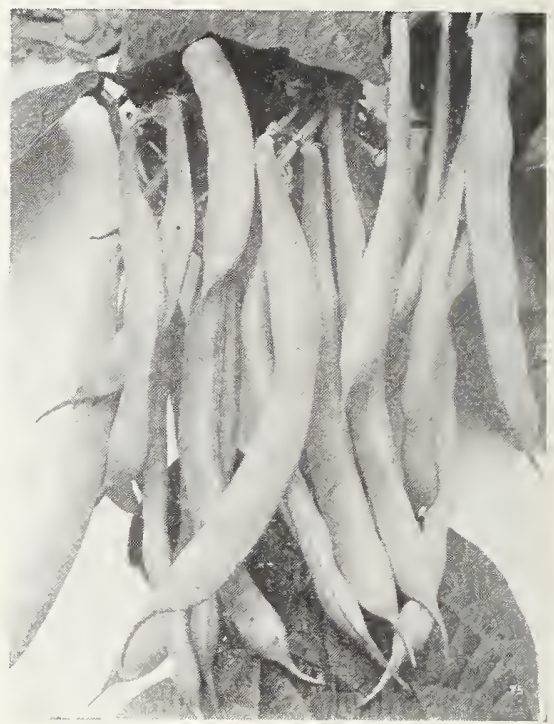

100-Nicholson's Giant Stringless

105-EARLY BLACK VALENTINE. Fin for long distance shipping. Can be planted earlier than other varieties on account of its hardiness and great resistance to bad weather conditions. Pkt., 10c; 1/2 lb., 20c; lb., 40c; 2 lbs., 75c; 5 lbs., $\$ 1.50$, postpaid. Not prepaid, 20 lbs., $\$ 3.25$; 50 lbs., $\$ 7.50 ; 100$ lbs., $\$ 14.00$.

Lavaca County, Texas.

I have enjoyed good results from the seed I ordered from you last season. It seems like every seed came up twice.

Yours truly.

R. B. NOLEN.

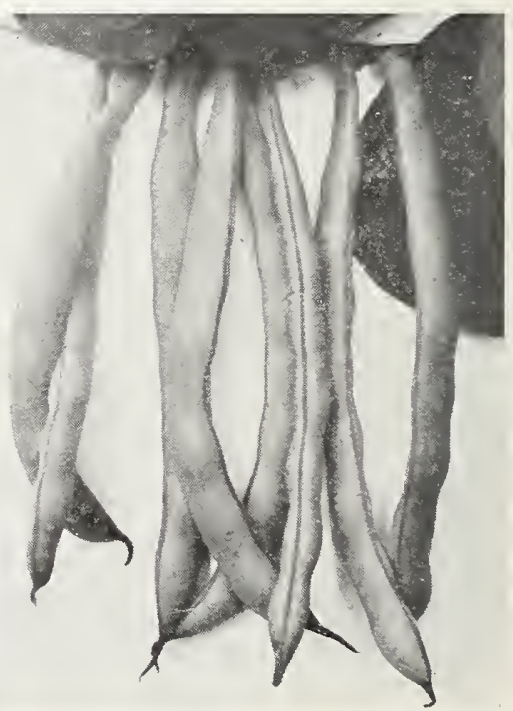

101-Burpee's Stringles: 


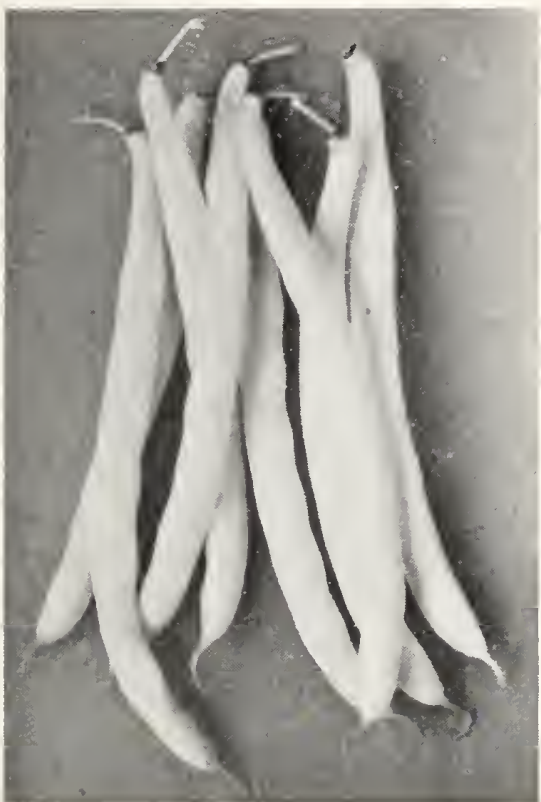

112-Pencil Pod Wax

\section{Bush Lima or Butter Bean}

(Frijoles de Lima Mata Baja)

One pound will plant 100 feet of drill. 114-HENDERSON'S SELECTED BUSH LIMA. The earliest of all Bush Limas, two weeks earlier than the climbing sorts. The plants are very robust, productive and hardy, will continue to make pods until frost. Pkt. 10c; $1 / 2$ lb., 20c; lb., 40c; 2 lbs., 75c: 5 lbs. $\$ 1.50$, postpaid. Not prepaid, 20 lbs., $\$ 3.50$ 50 lbs., $\$ 8.00 ; 100$ lbs., $\$ 15.00$.

115-NICHOLSON'S SPECKLED BUSH LIMA. The most prolific of all Limas; grows a very heavy bush and is a great drouth resister. Seed is brown, mottled with dark stripes, Pkt., 10c: 1/2 lb., 20c: lb., 40c: 2 lbs., 75c; 5 lbs., \$1.50, postpaid. Not prepaid, 20 lbs., $\$ 3.75 ; 50$ lbs., $\$ 8.50 ; 100$ lbs. $\$ 16.00$.

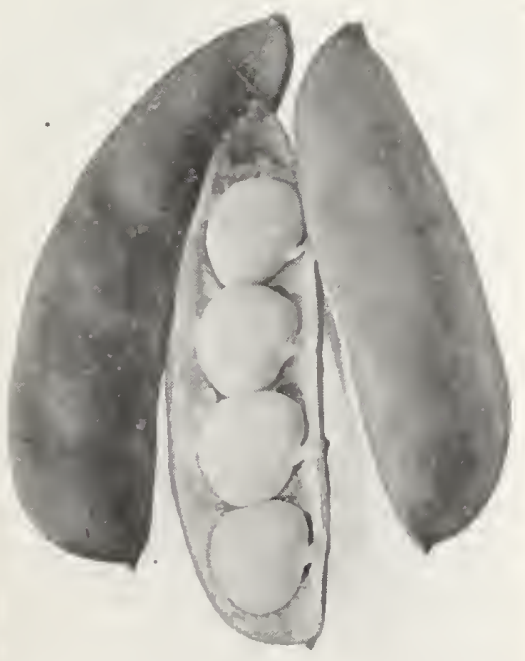

114-Henderson's Bush Lima
Nicholson's Wax or Yellow

\section{Pod Bush Beans}

Clase de Baja y Vaina Amarilla

110-NICHOLSON'S IMPROVED GOLDEN WAX. Pods are large, slightly flattened, bright yellow, brittle, and quite stringless while young. The bushes are of compact growth and very prolific. Highly recommended for home gardening. Pkt. 10c: 1/ lb., 20c; lb., 40c; 2 lbs., 75c; 5 lbs., $\$ 1.50$ postpaid. Not prepaid, 20 lbs., $\$ 3.75$; 50 Ibs. $\$ 8.50 ; 100$ lbs., $\$ 16.00$

111-PROLIFIC BLACK WAX. An im111-PRou Black Wax. One of the earliest of the Wax varieties, producing fine yellow, round, meaty pods of best quality. Pkt., 10c; $1 / 2$ lb., 20c lb., 40c: 2 lbs., 75c; 5 lbs., \$1.50, postpaid. Not prepaid, 20 lbs., \$3.75; 50 Ibs., $\$ 8.50$; 100 lbs., $\$ 16.00$.

112-PENCIL POD BLACK WAX. Handsome sort of the Wax variety. Pods are round, straight, bright yellow, very tender and stringless: grow from $51 / 2$ to 6 inches long. Pkt., 10c; 1/2 lb., 20c; lb., 40c; 2 lbs.. $75 \mathrm{c}$; 5 lbs., \$1.50, postpaid. Not prepaid, 20 lbs $\$ 3.75: 50$ lbs $\$ 8.50 \cdot 100$ lbs. $\$ 16.00$

113-W ARDWELL'S KIDNEY WAX. Vig orous grower, producing long, showy pods of a white, waxy appearance and free from rust; very tender. Bushes are very strong and prolific. Pkt., 10c; 1/2 lb., 20c; lb., 40c; 2 lbs., 75c: 5 lbs., \$1.50, postpaid. Not prepaid, 20 lbs., $\$ 3.75 ; 50$ lbs., $\$ 8.50 ; 100$ lbs $\$ 16.00$.

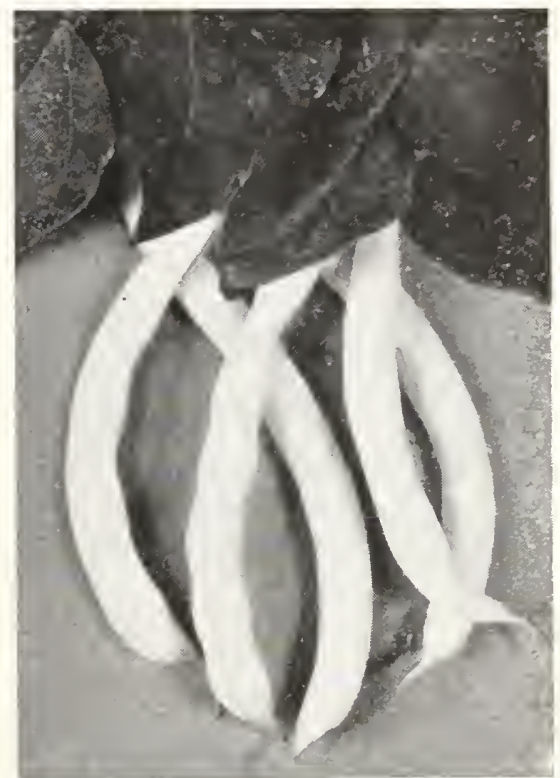

110-Improved Golden Wax

\section{Nicholson's Pole or Running Beans}

125-KENTUCKY WONDER or OLD HOMESTEAD. The standard of Pole Beans. It has proven itself to be the most prolific and profitable of them all. In fact, if the green pods are kept picked it will bear ureen pods are kept picked it with bear Matures in about eight weeks. Pkt., 10c: $1 / 2$ lb., 20c; lb., 40c; 2 lbs., 75c; 5 lbs., $\$ 1.50$, postpaid. Not prepaid, 20 lbs., $\$ 3.50 ; 50$ lbs., $\$ 8.00 ; 100$ lbs., $\$ 15.00$

126-KENTUCKY WONDER WAX You have the same Bean in this Wax Pole Bean as in the famous green variety. The pods are bright yellow, very thick, meaty and en. tirely stringless. Pkt., 10c; 1/2 lb., 25c; lb., $45 \mathrm{c}$ : 2 lbs.. 75c; 5 lbs., $\$ 1.75$, postpaid. Not prepaid, 20 lbs., $\$ 4.00$.

127-WHITE CREASEBACK. A splendid pole variety with round green pods; good bearer; grows well in corn: a good marketer. Pkt., 10c; 1/2 lb., 25c; lb., 45c; 2 lbs. 80c; 5 lbs., \$1.50, pestpaid. Not prepaid, 20 lbs., \$4.00; 50 lbs., \$9.00; 100 lbs., \$17.00. One lb. Pole Bean plants 150 feet of drill.

\section{Pole Lima Beans}

(Frijoles de Lima Trepadores) 129-SMALL WHITE LIMA CAROLINA OR SIEVA. Very early small seeded Pole Lima. Especially adapted to growing in the South. Vines vigorous and stand drouth well. Pkt., 10c; 1/2 lb., 20c; Ib., 40c; 2 lbs. $75 \mathrm{c}$; 5 lbs., \$1.50, postpaid. Not prepaid, 20 lbs., $\$ 4.00 ; 50$ lbs., $\$ 9.00 ; 100$ lbs., $\$ 17.00$.

130-NICHOLSON'S SPECKLED POLE LIMA. We recommend this variety very highly to the Southern planter. It is one of the hardiest Pole Limas, very prolific, making Beans for both green and dry use, Pkt. 10c $1 / 2$ lb., 25c; lb., 45c; 2 lbs., 80c; 5 lbs., $\$ 1.50$ $1 / 2$ lb., 25c; : Th., 45c; 2 lbs., 80c: 5 lbs., $\$ 1.50$,
postpaid. Not prepaid, 20 lbs., $\$ 4.00 ; 50$ lbs., $\$ 9.00 ; 100$ lbs., $\$ 17.00$.

LIMA BEANS RESPOND TO SEMESAN TREATMENT For prices and further information, see page 66 .
128-STRIPED CREASEBACK. A hardy and very productive green pod Pole Bean. Vines dark green and good climbers. Pods are long, about 6 inches, completely rounded, very fleshy. Pkt., 10c; 1/2 lb., 25c; lb., 45c; 2 lbs., 80c; 5 lbs., $\$ 1.75$, postpaid. Not pre $\$ 17.00$.

131-BALDWIN WONDER WAX. A long podded wax bean that has proven most popular with market gardeners. The pods are semi-flat measuring 5 to 6 inches long, require about the same time to make as Kentucky Wonders. An excellent variety for home use as well as the professional market gardener. Pkt., 10c; 1/2 lb., 25c: lb., 45c; 5 lbs., \$1.50, postpaid. Not prepaid, 20 lbs., $\$ 4.00 ; 50$ lbs., $\$ 9.00 ; 100$ lbs., $\$ 17.00$.

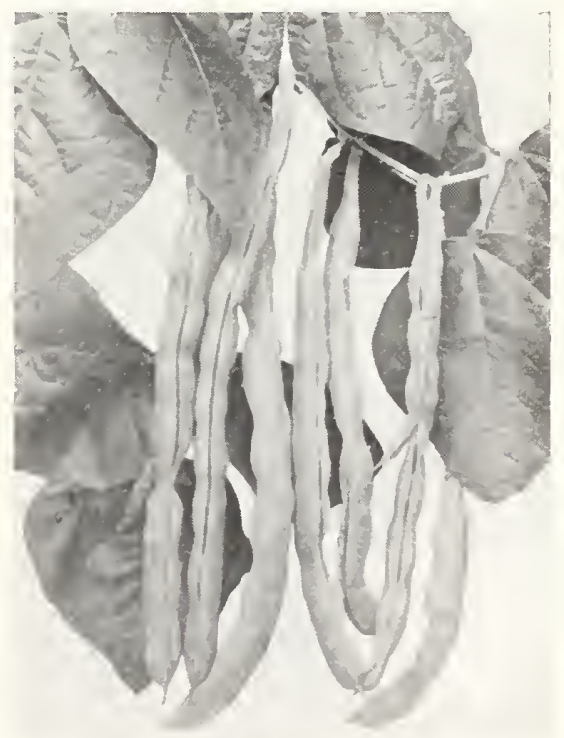

125-Kentucky Wonder paid, 20 lbs., $\$ 4.00 ; 50$ lbs., $\$ 9.00 ; 100$ lbs., 


\section{Robert Nicholson}

\section{Tender Garden Beets}

\section{(REMOLACHA PARA LA MESA)}

Beets do best in rich sandy loam, but may be grown in any good soil. Seed may be sown in early spring also for fall planting. One ounce will sow 100 feet of drill or 6 to 8 pounds per acre. Ask for prices on larger quantities.

139-LONG SMOOTH BLOOD RED. Has long, smooth, blood-red roots, growing well down in the soil, enabling it to resist the drouth and heat. Pkt., 5c; oz., 15c; 1/4 lb., 35 c; lb., $\$ 1.00$; 5 lbs., $\$ 4.00$, postpaid. Not prepaid, 10 lbs., $\$ 6.00$; 100 lbs., $\$ 50.00$.

140 -NICHOL'SON'S EARLY WONDER. Similar to the Crosby's Egyptian, but is claimed to be earlier and is very uniform in growth. Roots are globular in shape, slightly flattened: color bright red. Pkt., 5c; oz., 15 c; $1 / 4$ lb., 35c; lb., $\$ 1.00$; 5 lbs., $\$ 4.00$, postpaid. Not prepaid, 10 lbs., $\$ 6.00 ; 100$ lbs., $\$ 50.00$.

137-DETRO1T DARK RED. Has medium sized roots, globular or nearly round, very smooth, and of a dark blood-red color. The flesh is an attractive vermilion-red with zones of a lighter shade, very tender and free from strings. Pkt., 5c; oz. 15c; 1/4 lb., $35 \mathrm{c}$; lb., $\$ 1.00$; 5 lbs., $\$ 4.00$, postpaid. Not prepaid, 10 lbs., $\$ 6.00 ; 100$ lbs., $\$ 50.00$

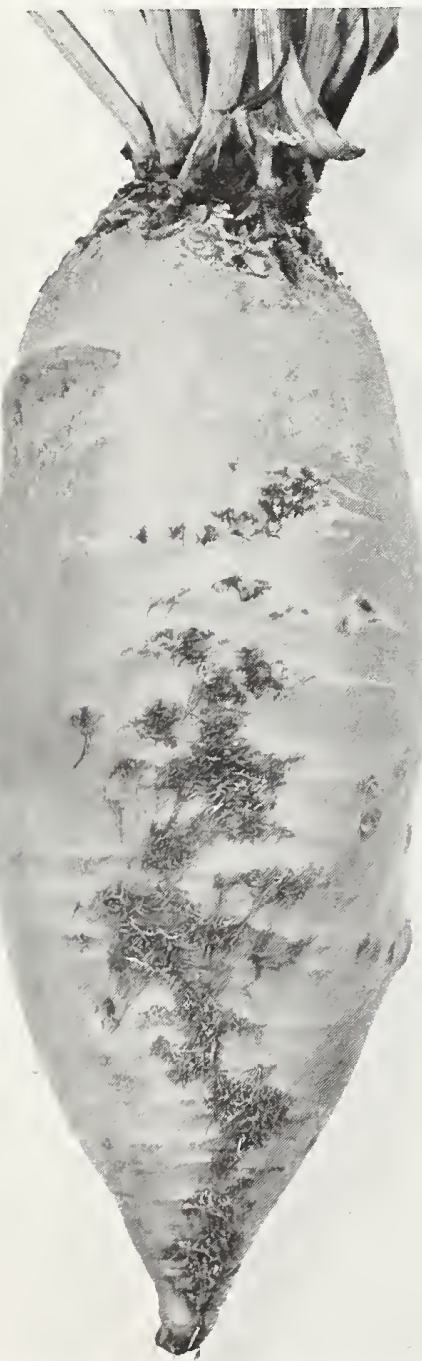

145-Stock Beet
135-EARLY ECLIPSE. Early, round smooth and dark red. Pkt., 5c; oz., 15c; 1/4 lb., 35c; lb., $\$ 1.00$; 5 lbs., $\$ 4.00$, postpaid Not prepaid, 10 lbs., $\$ 6.00 ; 100$ lbs., $\$ 50.00$. 136-IMPROVED EARLY BLOOD TURNIP BEET. Color deep blood-red; very sweet and free from strings. Smooth; uni form in size. Pkt., 5c; oz., 15c; 1/4 lb., 35c; lb., $\$ 1.00 ; 5$ lbs., $\$ 4.00$, postpaid. Not prepaid, 10 lbs., $\$ 6.00 ; 100$ lbs., $\$ 50.00$.

138-CROSBY'S EGYPTIAN. Because of its extreme earliness, attractive appearance and other good qualities, this variety leads all others in favor among market gardeners, at the same time being unexcelled as a home garden sort. The exterior color of the root is bright red, and the flesh is bright red zoned with a lighter shade. Pkt., 5c; oz. 15c; 1/4 lb., 35c; lb., \$1.00; 5 lbs., \$4.00, postpaid. Not prepaid, 10 lbs., $\$ 6.00 ; 100$ lbs. $\$ 50.00$.

Scutry County, Texas.

We were so well pleased with the seeds ordered last year. Ours did so much better than the neighbors, they are sending to you this year.

Yours very truly.

MRS. J. H. HANNABASS.

\section{Mangels or Stock Beets} Green Stock Feed

(Remolachas y Nabos Para El Ganado)

Mangels or Stock Beets are a splendid winter feed for cattle and hogs. Increases the milk yield from cows. Puts animals in better physical condition. Yield larger crops than turnips and are of greater feeding value. The best food in existence for all kinds of livestock. Over 40 tons have been grown on a single acre, and in feeding value this is equal to 130 bushels of corn.

CULTURE. Much depends on good culture, so prepare your land thoroughly and plow deeply. Sow from about the middle of March until the middle of June, and give thorough cultivation. After the first cultivation, thin out, so as to stand six inches apart in the row, and cultivate like corn. If late in planting, soak the seeds for 24 hours before planting. Sow 4 to 5 pounds to the acre in rows $2 \frac{1}{2}$ feet apart.

145-NICHOLSON'S MAMMOTH LONG RED. These Beets, on good soil, sometime grow 18 inches long. Dark leaves; flesh white with veined rings of rose-pink. An excellent keeper; nutritious and milk producing. Oz., 10c; $1 / 4 \mathrm{lb}, 20 \mathrm{c}$; lb., 60c; $5 \mathrm{lbs}$. $\$ 2.50$, postpaid.

146-NICHOLSON'S GIANT FEEDING HALF SUGAR. A strain of Beets very desirable for stock feeding, affording not only a very large crop, but exceedingly rich in sugar and other nutritive elements. The roots average 10 to 12 inches, and the outline is that of a broad, thick wedge. The upper portion is of a soft, bright pink, shading lighter toward the bottom. Oz., 10c $1 / 4 \mathrm{lb}$., 20c; lb., 60c; 5 lbs., \$2.50, postpaid.

147-GOLDEN TANKARD. Flesh firm an solid, and a rich golden yellow color. On account of its peculiar shape they can be grown closer than most Mangels, increasing the yield per acre considerably. Grows well above ground and is easily pulled. Yields particularly well on light soils. Oz., 10c $1 / 4$ lb., 20c; lb., 60c; 5 lbs., $\$ 2.50$, postpaid.

Any of the above varieties of Stock Beets, not prepaid, 10 lbs. or over at $40 \mathrm{c}$ per lb.

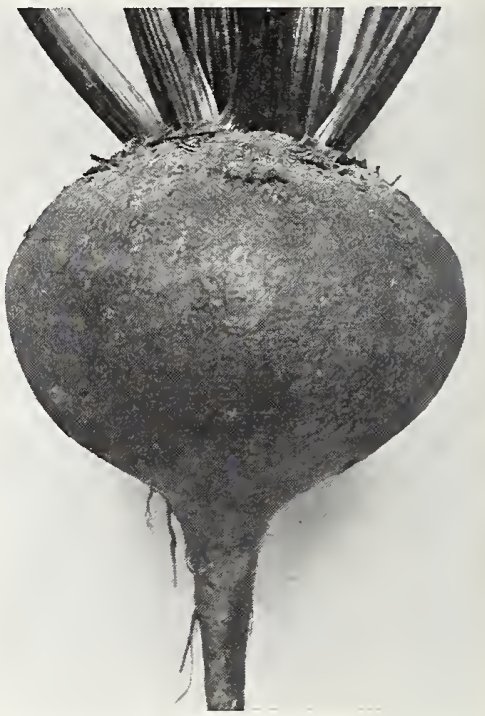

Crosby's Egyptian

\section{1-Swiss Chard or Spinach Beet}

"Cut and Come Again." This vegetable gives maximum return for little care and space; it is almost a constant crop, standing heat and cold to a greater extent than any other vegetable we know of. We had reports of several crops of Swiss Chard that stood the extreme cold. If your garden space is limited you must make a place for this wonderful green. In proportion to the ground occupied it will produce more food for the table than any other vegetable. It can be used all summer when spinach is not available. The leaves grow very large and make an excellent green for table use. The midrib of the leaf may be cooked like asparagus, you will find this to be a very tasty dish. Plant in spring or fall. Pkt., 5c; oz., 15c; 1/4 lb., 35c; lb., \$1.00; 5 lbs., $\$ 4.25$, postpaid. Not prepaid, $10 \mathrm{lbs}$. $\$ 7.00$.

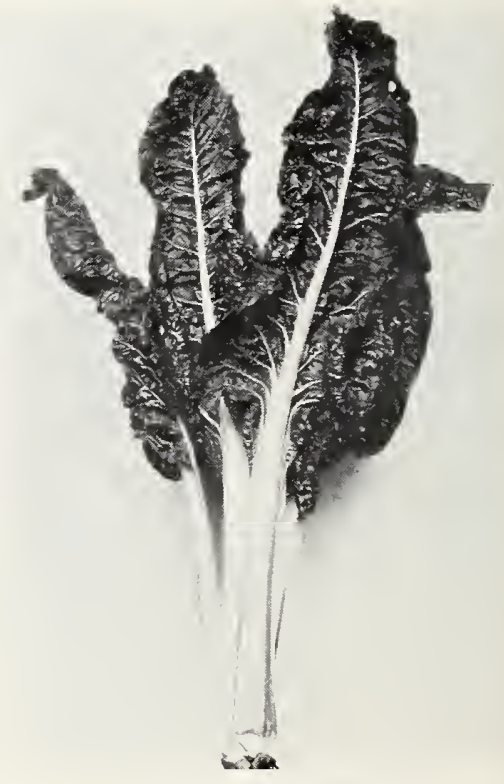

141-Swiss Chard 
$(\mathrm{Col}$ Repello)

\section{Especially Adapted to The South}

Our Cabbage seed is grown by the most reliable and responsible growers. We believe there is no seed more reliable and none that will give the Southern planter more satisfactory or better results. For plants in hotbeds, sow seed early in January, then transplant in open in February and March. Later sow early varieties out-of-doors in March and April. For winter Cabbage, sow seed in July, August and September, then transplant in October. One ounce of seed will produce about 3000 plants; 10 ounces of seed will produce enough plants to set out an acre in rows 30 inches apart.

\section{Second Early and Inter- mediate Varieties}

159-STEIN'S EARLY FLAT DUTCH. One of the most popular market garden varieties, and equally desirable for the home garden. Will hold in good condition a long time after being cut. Heads are large, only slightly flattened, and very firm and solid. Pkt., 10c; 0z., 20c; 1/4 lb., 60c; lb., \$2.00: 5 lbs., \$8.75, postpaid. Not prepaid, 10 lbs. or over at $\$ 1.50$ per lb.

160-GLORY OF ENKHUIZEN. This second early variety is very sure heading and of excellent quality. The heads are very nearly round, very solid and of large size for so early a variety. Pkt. 10c: oz, 25c: 1/4 lb., 60c: lb., \$2.00; 5 lbs., \$9.00, postpaid. Not prepaid, 10 lbs. or over at $\$ 1.60$ per $1 b$. 161-SUCCESSION. A good second early, and a splendid general purpose Cabbage for both spring and fall planting. Medium to large. solid, reliable header Pkt 10c: oz $20 \mathrm{c}$; $1 / 4 \mathrm{lb} ., 60 \mathrm{c}$; lb., $\$ 2.00$; 5 lbs., $\$ 8.75$, postpaid. Not prepaid, 10 lbs. or over at $\$ 1.50$ per lb.

162-ALL SEASONS. Heads very deep, splendid keeper. Medium early, forming large, fine heads of the finest quality Pkt., 10c: oz., 20c; 1/4 lb., 60c; lb., \$2.00; 5 lbs., \$8.75, postpaid. Not prepaid, 10 lbs. or over at $\$ 1.50$ per $l b$.

163-SURFHEAD. Produces large, round, flat heads of the Flat Dutch type; fine texture Pkt, 10c: oz, 20c; 1/1 lb, 60c: lb. $\$ 2.00$; 5 lbs., $\$ 8.75$, postpaid. Not prepaid, $10 \mathrm{lbs}$. or over at $\$ 1.50$ per lb.

165-MAMMOTH ROCK RED. This is the largest and surest heading red cabbage. It may be used rather early, but remains in prime condition until frost. The plant is medium sized, very vigorous and spreading. while the head is large, purplish red in color, round, about 8 inches in diameter, and weighs 6 to 8 pounds. It is very hardy and of excellent quality. Popular for pickling. Pkt., 10c; 0z., 35c; 1/4 lb., \$1.00; lb., \$3.50, postpaid.

\section{Late or Autumn and Winter} 164-PREMIUM LATE FLAT DUTCH. The old favorite for fall and winter use. Grows low to ground, heads large, bluish green in color, broad and flat top. Pkt., 10c; oz., 20c; $1 / 1 /$ lb., $60 \mathrm{c}$; lb., $\$ 2.00$; $5 \mathrm{lbs} ., \$ 8.75$. postpaid. Not prepaid, 10 lbs. or over at $\$ 1.50$ per lb.

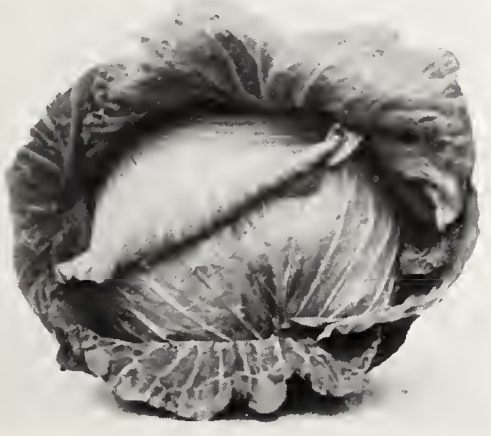

159-Stein's Early Flat Dutch

\section{First Early Cabbage}

155-ALL HEAD EARLY. An extra flat head variety and sure header. Has very few outer leaves. One week later than Jersey Wakefield, and is considered to be one of the finest varieties of early medium size flat head Cabbage in existence. Pkt., 10c; oz. 20 ; $1 / 4$ lb., 60c; lb., $\$ 2.00 ; 5$ lbs., $\$ 8.75$, postpaid. Not prepaid, 10 lbs. or over at $\$ 1.50$ per lb.

156-EARLY JERSEY WAKEFIELD. The finest of the early cone-shaped head varieties and is a standard everywhere it is used. Pkt. $\$ 8.75$, postpaid. Not prepaid, $10 \mathrm{lbs}$. or over at $\$ 1.50$ per $1 \mathrm{~b}$.

157-COPENHAGEN MARKET. A roundheaded Cabbage as early as Wakefield: besides being early it grows to large size usually about 10 pounds. It is fine grained tender, and has a heart of pure white, of exceptionally good quality. Pkt., 10c; oz. postpaid. Not prepaid, 10 lbs, or over at $\$ 2.00$ per lb.

158-CHARLESTON WAKEFIELD. About one week later than the Early Jersey Wakefield, and makes much larger heads; is very popular. Pkt., 10c; 0z., 20c; 1/4 lb., 60c; Ib., $\$ 2.00$; 5 lbs., $\$ 8.75$, postpaid. Not prepaid, 10 lbs. or over at $\$ 1.50$ per $\mathbf{l b}$.

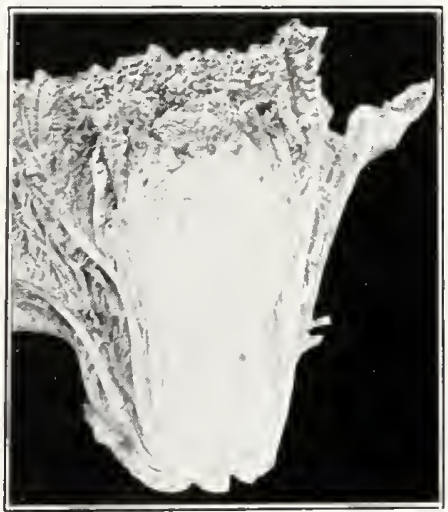

166-Chinese Cabbage

\section{Chinese Cabbage}

This exceptionally fine vegetable resembles both celery and lettuce, as well as cabbage, to which family it really belongs. Very easy to grow, and should be planted and cultivated in the same way as cabbage, lettuce and other similar vegetables.

166-CHINESE CABBAGE. Has long heads, broadening out at the top, held very compact and firm by the tightly overlapping leaves. The heads are perfectly blanched in side, and are very delicious served as a salad tion of the leaves may be cooked like spinach, while the heavy midribs are very palatable like Swiss Chard or Asparagus. Pkt., 10c oz., 25c; $1 / 4$ lb., 85c; lb., $\$ 2.75$, postpaid.

For prices on Nicholson's Frostproof Cabbage Plants, see Page 38 . 10c; oz., 20c; $1 / 4$ lb., 60c; lb., $\$ 2.00 ; 5$ lbs. $30 \mathrm{c}$; $1 / 4 \mathrm{lb}$., 90c; $1 \mathrm{~b} ., \$ 2.75 ; 5$ lbs., \$11.50, or slaw, with mayonnaise. The green por-

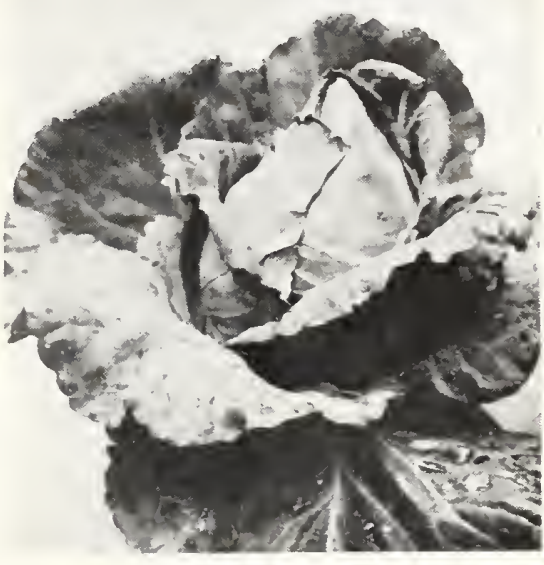

158-Charleston Wakefield

\section{Broccoli}

\section{(Broculi)}

The hearls of Broccoli are very similar to Cauliflower, only coarser, and the plant is more hardy. Should be grown and cultivated in the same way as cabbage and cauli. flower. One ounce will produce about 3000 plants. $150-$ EARLY GREEN CALABRESE. Makes a fair sized green head of good quality, and after this is cut, new sprouts develop, which make smaller heads for a second crop. Pkt. 10c: $1 / 1$, oz., 25c: 0z., 75c: $1 / 3$ lb., $\$ 2.25$, postpaid.

\section{Brussels Sprouts}

A member of the cabbage family that produces small miniature cabbages growing closely on the stalk, a small head being formed at each leaf joint. The plant is very hardy and will live through the winter months in most sections of the South. Plant in the same manner as cabbage.

151-BRUSSELS SPROUTS. Improved dwarf variety. Pkt., 10c; oz., 25c; 1/s lb. $75 \mathrm{c}$; lb.. $\$ 2.50$, postpaid.

\section{Cauliflower}

Can be grown in cabbage. All they need is rich soil and plenty of water. One ounce will produce about 3000 plants

194-EARLY SNOWBALL. Undoubtedly finest variety ever introduced. Produces beautiful snow-white heads of finest flavor. Pkt., 20c: 3/2 0z., \$1.00; 0z., \$1.50; 1/4 lb. $\$ 5.50$, postpaid.

195-DRY WEATHER. Specially adapted for Southern planting. Pkt., 20c: $1 / 0 \mathrm{~m}$ $\$ 1.00$; oz., $\$ 1.50 ; 1 / 4$ lb., $\$ 5.50$, postpaid.

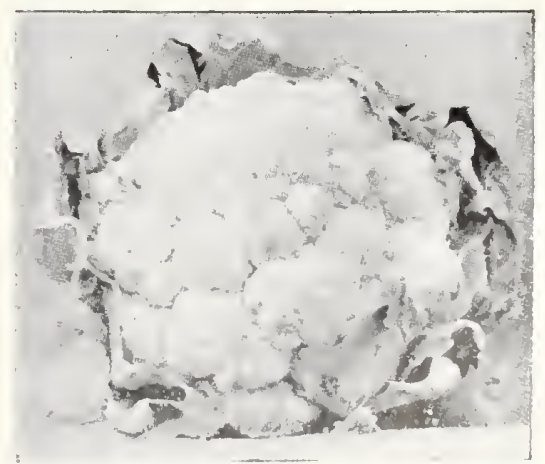

194-Cauliflower-Early Snowball 


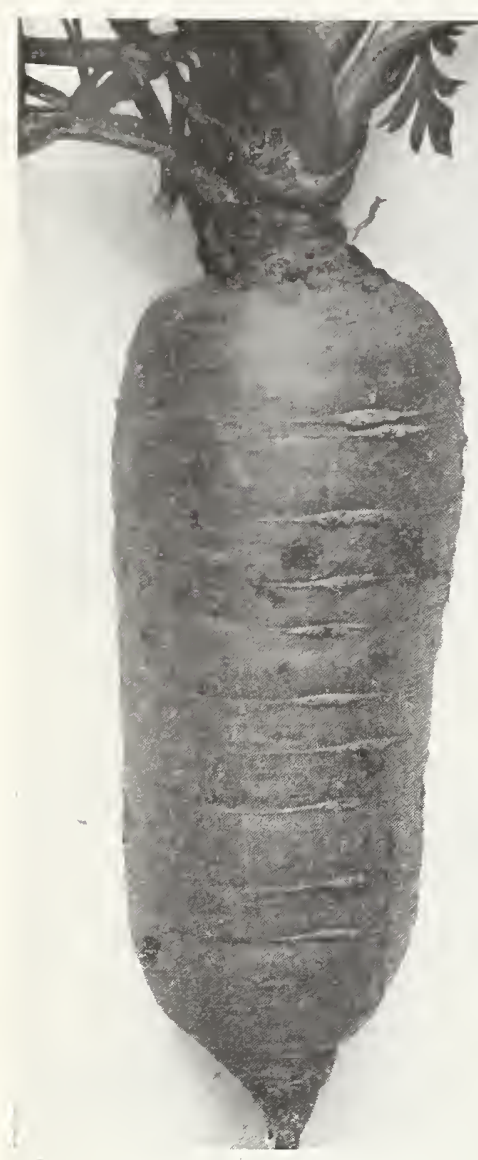

175-Carrot-Chantenay

\section{Garden and Sweet Corn (MAIZ DULCE)}

Ask for prices in larger quantities.

200-ADAMS EXTRA EARLY. The earliest variety of Corn for roasting ears; matures in 60 to 65 days. Plant 10 to 12 pounds per acre. Pkt., 10c; lb., 25c; 2 lbs., 45c; 5 lbs., 90c, postpaid. Not prepaid, 10 lbs. or over at $12 \mathrm{c}$ per lb.

201-ADAMS EARLY. Matures about a week later than Adams Extra Early; makes larger ears and is planted more extensively for home use; also for market. Pkt., 10c; lb., 25e; 2 lbs., 45c; 5 lbs., 90c, postpaid. Not prepaid, 10 lbs. or over at $12 \mathrm{c}$ per $\mathrm{lb}$.

202-GOLDEN BANTAM. This is the sweetest of the Sweet Corns; although the ears are small, it is very hardy and grows beautiful, well filled, golden ears, which cannot be beat for table use. Pkt., 10c; 1/2 lb., 15c; lb., 30c; 2 lbs., 55c; 5 lbs., \$1.25, postpaid. Not prepaid, $10 \mathrm{lbs}$. or over at $16 \mathrm{c}$ per lb.

203-COUNTRY GENTLEMAN. This variety has small cob with deep kernels; fine for canning as well as roasting ears. Pkt., $10 \mathrm{c} ; 1 / 2$ lb., 15c; lb., 30c; 2 lbs., 55c; 5 lbs., $\$ 1.25$, postpaid. Not prepaid, $10 \mathrm{lbs}$, or over at $16 \mathrm{c}$ per lb.

205-TRUCKER'S FAVORITE. Makes fine roasting ears in 65 to 85 days. Pkt., 10c: lb., 25c; 2 lbs., 45c; 5 lbs., 90c, postpaid. Not prepaid, 10 lbs. or over at $12 \mathrm{c}$ per lb.

206-STOWELL'S EVERGREEN. The standard wrinkled variety. Pkt., 10c; 1/2 lb., 15c; Ib., 30c; 2 lbs., 55c; 5 lbs., $\$ 1.25$, postpaid Not prepaid. 10 lbs. or over at $16 \mathrm{c}$ per $1 \mathrm{~b}$.

\section{Nicholson's Delicious Carrots}

\section{(ZANABORIAS)}

One ounce will sow 75 feet of drill; 4 pounds per acre.

Eat more Carrots for your health's sake. Can be combined with fruits and chopped nuts into a most delightful uncooked salad. Unsurpassed for stews and soups, yet prepared alone with a rich cream or butter sauce is a dish that is rich in food value and makes a well balanced meal when meats are served.

Culture. Carrots do best in a rather sandy loam soil. Should be planted in drills 2 feet apart and thinned to 2 inches. For early crop plant seed in February and March.

176-OXHEART or GUERANDE. A good variety on soils too hard and stiff for the longer-growing sgrts. The root is short, very thick and has a small tap-root; flesh is a bright orange color, fine grained and sweet flavor. Pkt., 10c; oz., 15c; 1/4 lb., 35c; lb., $\$ 1.00$; 5 lbs., $\$ 4.00$, postpaid. Not prepaid, $10 \mathrm{lbs}$, or over at $70 \mathrm{c}$ per $1 \mathrm{~b}$.

178-LONG ORANGE. Old standard long variety, suitable for table use; also for stock feeding. Pkt., 5c; oz., 10c; 1/4 lb., 25c; lb., $85 \mathrm{c} ; 5$ lbs., $\$ 3.80$, postpaid. Not prepaid, 10 lbs. or over $65 \mathrm{c}$ per lb.

179-WHITE BELGIAN. The Belgian Carrot is an immense cropper, often producing 15 to 20 tons per acre. Stock Carrots fed with dry feed keep animals in good condition, and are a great milk producer. Pkt., 5c; oz., 10c; 1/4 lb., 25c; lb., 80c; 5 lbs., $\$ 3.25$, postpaid. Not prepaid, $10 \mathrm{lbs}$. or over at $50 \mathrm{c}$ per lb.

175-CHANTENAY. This variety is slight ly shorter and more stump-rooted than Danvers Half-Long. Grows very uniform in size and shape, about $f$ inches Iong, with finely cut shoulders, tapering slightly. Flesh is deep golden orange color, crisp and sweet. A very popular market variety. Pkt., 10c; oz., 15c; $1 / 4$ lb., 35c; lb., $\$ 1.00 ; 5$ lbs., $\$ 4.00$, postpaid. Not prepaid, 10-lb, lots at 70c per lb. Ask for prices in larger quantities.

177-DANVERS HALF-LONG. A rich or ange-red variety, very smooth and handsome, producing very large crops, An excellent market variety. Tops are of medium size and coarsely divided. The roots taper to a blunt point; flesh sweet, crisp and tender Pkt., 10c; oz., 15c; 1/4 lb., 35c; lb., \$1.00 : 5 lbs., \$4.00, postpaid. Not prepaid, $10 \mathrm{lbs}$. or over at $70 \mathrm{c}$ per lb.

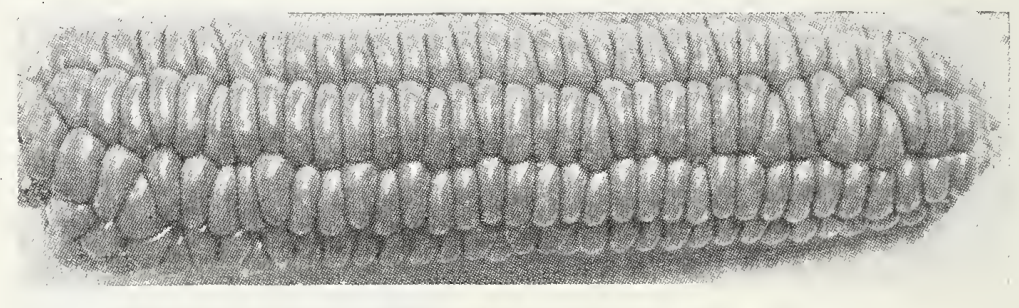

202-Golden Bantam Sweet Corn

\section{Early Field Corn (FOR ROASTING EARS)}

210-EARLY WHITE PEARL. Northern grown: makes good sized ears of splendid quality: matures in about 90 days. Pkt., 10c. quality; matures in about 90 days. Pkt., 10c; See field seed for prices in larger quantities.

211-HICKORY KING. Also known as the old 8-row Corn; small cob with wide grains. Matures in about 100 days. Pkt., 10c; lb. 20c; 2 lbs., 35c; 5 lbs., 75e postpaid. See field seed for prices in larger quantities.

212-SURECROPPER. Its sureness to make has made it one of the most popular varieties. Matures about the same time as Hickory King. Pkt.. 10c; lb., 20c; 2 lbs., 35c; 5 lbs., $75 \mathrm{c}$, postpaid. See ficld seed for prices in larger quantitics.

\section{Pop Corn}

For Planting or Popping.

NICHOLSON'S GOLDEN HEART (SHURPOP). A very tender popping Corn which shows a wonderful expansion on popping. Grows well in Texas and the South. Lb. $30 \mathrm{c} ; 2$ lbs., 55c, postpaid. Not prepaid, 10 lbs. or over, $121 / 2 \mathrm{c}$ per $l b$.

215-WHITE RICE. Lb., 30c, postpaid. Not prepaid, $10 \mathrm{lbs}$. or over at $10 \mathrm{c}$ per $\mathrm{lb}$.

216-LITTLE BUSTER OR JAPANESE HULLESS. Produces well in the South. Extra small grains and excellent for popping. A good yielder. Lb., 30c, postpaid. Not prepaid, $10 \mathrm{lbs}$. or over at $11 \mathrm{c}$ per $1 \mathrm{~b}$.

217-SOUTH AMERICAN. A large yellow grain Corn that grows well in the South. Golden colored when popped and has a distinet flavor. Try this new variety. Lb., 30c; 2 lbs., 55c; 5 lbs., $\$ 1.00$, postpaid. Not prepaid, 10 lbs. or over at $12 \frac{1}{2 c}$ per lb.

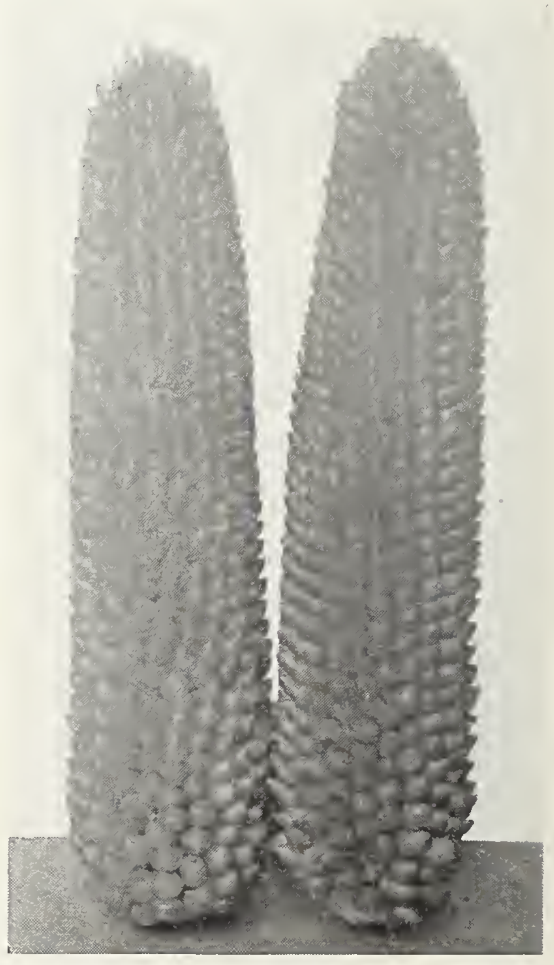

216-Popcorn 


\section{Tested Seeds for}

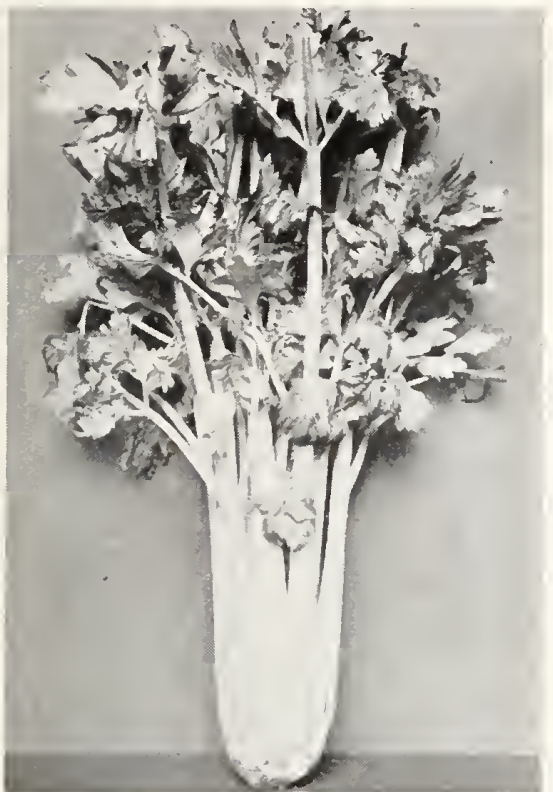

182-Celery

\section{Celery \\ (Apio)}

Celery seed is slow to germinate and ample time must be given. Sow thinly, cover lightly and keep constantly moist. Count on about 4000 plants per ounce, or one-fourth pound per acre.

182-GOLDEN SELF-BLANCHING.

The plant is naturally golden yellow (both stem and leaves), but needs to be blanched to make it brittle. Pkt., 10c; oz., 75c; 1/4 lb., $\$ 2.00$; lb., $\$ 6.50$, postpaid.

\section{Collards}

\section{(Colessin Cabeza)}

185-GEORG1A or SOUTHERN. The standard variety of Collards planted all over the South. Sow seed as for cabbage. Pkt., 5c; oz., 10c; $1 / 1$ lb., 25c; lb., 75c; 5 lbs., $\$ 3.00$, postpaid. Not prepaid, $10 \mathrm{lbs}$. or over at $50 \mathrm{c}$ per lb.

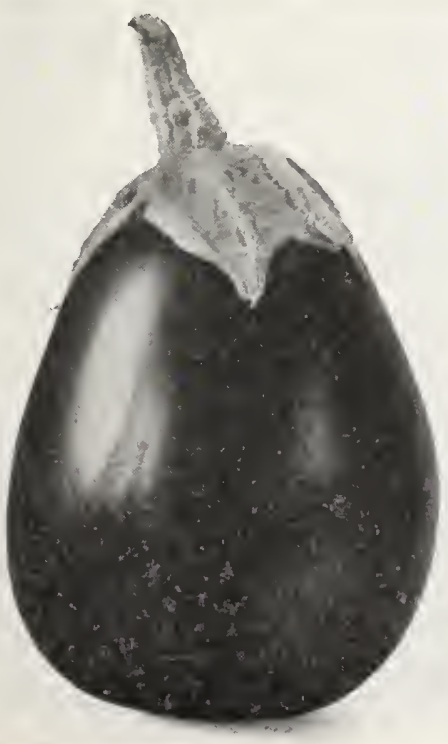

197-Egg Plant

\section{Nicholson's Improved Cucumber}

\author{
(СоHOMBRO)
}

Form low, flat hills, six feet apart each way, of rich soil, by mixing in a quantity of the shallow trenches six to eight feet apart and mix with the bottom earth a quantity of similar manure and replace the surface soil. Scatter on each hill 15 to $20 \mathrm{seeds}$, or one every inch along the rows, and cover one inch deep, pressing the soil firmly. Two ounces for every 100 hills; two pounds per acre.

225-CHICAGO PICKLING. The best and most popular variety for pickling. Has small, deep green fruits, tapering at each end; is very prolific. Pkt., 10c; oz., 15c; 1/4 lb., 40c; lb., $\$ 1.25 ; 5$ lbs., $\$ 5.00$, postpaid. Not prepaid, $10 \mathrm{lbs}$. or over at $85 \mathrm{c}$ per lb.

226-KLONDYKE. An attractive dark green variety, fruits 7 to 8 inches long, regular in size and shape: extra early, crisp, and unsurpassed for slicing. Pkt., 10c; oz., 15c; $1 / 4$ lb., 40c; lb., $\$ 1.25 ; 5$ lbs., \$5.00, postpaid. Not prepaid, 10 lbs. or over at $85 \mathrm{c}$ per lb.

227-LONG GREEN. One of the earliest long green varieties, fruit 10 to 12 inches long, and of a rich dark green color; fine for shipping: also a good pickling variety when young. Pkt., 10c; oz., 15c; $1 / 4 \mathrm{lb} ., 45 \mathrm{c}$; lb., $\$ 1.50 ; 5$ lbs., $\$ 6.00$, postpaid. Not prepaid, 10 lbs. or over at $\$ 1.00$ per lb.

228-ARLINGTON WHITE SPINE. An old-timer and a good one. Pkt., 10c; oz., 15c ; $1 / 4$ lb., 40c; lb., $\$ 1.25 ; 5$ lbs., $\$ 5.00$, postpaid. Not prepaid, $10 \mathrm{lbs}$, or over at $85 \mathrm{c}$ per lb.

229-JAPANESE CLIMBING, While all Cucumbers are running vines this variety is much more so than others. It climbs quickly on poles and trellises, and is entirely distinct. Splendid quality and well adapted for pickling and salad. Pkt., 10c; oz., 20c; 1/4 lb., 50c; lb., $\$ 1,50$, postpaid

230-FARLY CLUSTER. Very early variety, bearing in clusters of two and three. If kept gathered from the vines it will continue to fruit through a long season. This is a splendid variety for pickling. Pkt., 10c; oz., 15c; 1/4 lb., 40c; lb., \$1.25; 5 lbs., \$5.00, postpaid. Not prepaid, 10 lbs. or over at $85 \mathrm{c}$ per lb.
231-DAVIS PERFECT. Ideal Cucumber color, uniform in size and almost seedless, which makes it very desirable for slicing Pkt., 10c; oz., 15c; 1/4 lb., 45c; lb., \$1.25; lbs., $\$ 6.00$, postpaid. Not prepaid, 10 lbs, over at $\$ 1.00$ per $1 b$.

232-EARLY FORTUNE. An exceptionally fine early and productive Cucumber; an im proved strain of the White Spine. Unex celled for shipping or for home use. Pkt., 10c $0 z, 15 \mathrm{c}$ : 1/4 $40 \mathrm{c}$ : lb, $\$ 1.25 ; 5$ lbs. $\$ 5.00$ postpaid. Not prepaid, 10 lbs., or over at 85 r per $1 \mathrm{~b}$.

233-LEMON. Fruits are round or slightly oval, and of a light creamy yellow color. It is very prolific, and is especially desirable as a small pickling variety for which purpose it may be used either green or ripe. Pkt. 10c; 0z., 20c; $1 / 4$ lb., 55c, postpaid.

234-NICHOLSON'S PREMIUM. This won derful new cucumber is only slightly longer than the Early Fortune, but is twice as desir. able from a standpoint of color. A solid black green with no white stripes at the blossom end and will retain its color almost twice as long as other cucumbers. The meat is crisp and tender. It will retain its dark green color long after being cut from the vine. This great cucumber should prove to be a find for the critical market gardener as well as for the home garden. If you grow cucumbers, give this one a trial. Pkt., 10c postpaid. Not prepaid, 10 lbs, or over, $\$ 1.25$ per lb. for shipping and home use. Dark green in oz., 20c; $1 / 4$ lb., $50 \mathrm{c}$; lb., $\$ 1.75 ; 5$ lbs., $\$ 7.50$

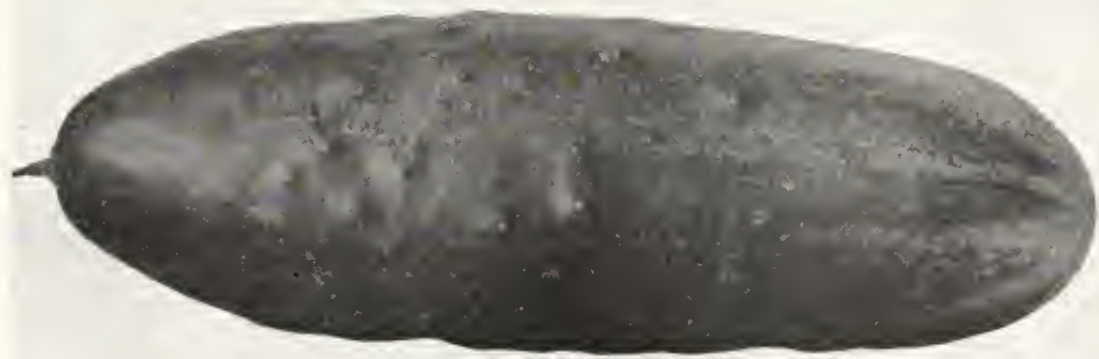

234-Nicholson's Premium Cucumber

Egg Plant (BERENJENAS)

One $10 \mathrm{c}$ pkt. of seed will make plants for 200 feet of row.

Eggplant should be sown in hotbeds in March and April, and planted during June in rows $2 \frac{1}{2}$ feet apart. Cultivation same as for cabbage.

196-NICHOLSON'S BLACK BEAUTY. Nearly two weeks earlier than any other variety, producing large thick, luscious purplish fruits of the finest quality. Pkt., 10c: purplish fruits of the finest quality. Pkt., 10c; postpaid.

197-NICHOLSON'S NEW YORK IMPROVED PURPLE SPINELESS. The leading market variety, and undoubtedly the best for size, quality and productiveness. Pkt.. 10c; oz., 45c; 1/4 lb., $\$ 1.35$; lb., $\$ 4.75 ; 5$ lbs., $\$ 20.00$, postpaid.

\section{Endive}

(ENDIVIA

Endive is largely used as a salad plant an can be grown practically all the year round

187-GREEN CURLED ENDIVE. Ricb reen in color, but blanching to cream white Pkt., 10c; oz., 15c; 1/4 lb., 40c; lb., \$1.25. postpaid.

\section{Horseradish}

Horseradish is grown from pieces of the root. Plant in rows $2 \frac{1 / 2}{2}$ feet apart, setting roots 18 inches apart in rows, vertically. small end down, and top 1 to 3 inches belox surface. 40c per dozen, postpaid.

HOTKAPS-Your assurance of earlier and bigger crops. 


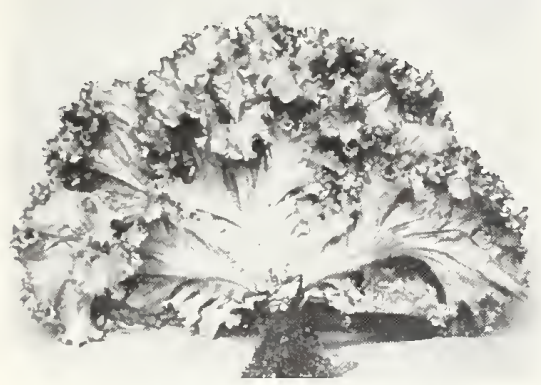

246-Early Curled Simpson

246-EARLY CURLED SIMPSON. A very popular bunching variety; light green in colpaid. Not prepaid, 10 lbs. or over at $\$ 1.00$ per lb. 240-NICHOLSON'S NEW YORK MAMMOTH. The finest heading variety we know and is grown by leading market gardeners throughout the South and Southwest. Leaves thick, firm, of the crisp type, forms large heads and is the favorite shipping variety. Pkt., 10c; oz,, 25c; 1/4 lb., 75c; lb., \$2.50; 5 lbs., \$11.25, postpaid. Not prepaid, $10 \mathrm{lbs}$. or over at $\$ 1.75$ per lb.

241-NICHOLSON'S BIG BOSTON. A favorite among the old standard varieties of head Lettuce, producing large, solid heads almost as large as New York Mammoth, and of fine quality. Pkt., 10c; oz., 20c; 1/4 lb., $50 \mathrm{c}$; lb., $\$ 1.50 ; 5$ lbs., $\$ 6.00$, postpaid. Not prepaid, $10 \mathrm{lbs}$. or over at $\$ 1.00$ per lb.

247-COS OR ROMAINE. This variety is quite distinct from the other varieties of lettuce. It is often spoken of as French Lettuce and has grown in demand since the World War as the boys that went over "learned to like it". The variety we handle is dark green in color for the outer leaves, the inner leaves are white with the faintest tint of green. The quality is especially succulent and sweet. Pkt., 10c; oz., 20c; 1/4 lb., $60 \mathrm{c}$; lb., $\$ 1.75 ; 5$ lbs., $\$ 7.00$, postpaid.

\section{Kale}

\section{(BRETON-BERZA)}

Kale is used for greens; a large producer. For winter crop sow from August through the fall in drills two feet apart, thin out to 8 inches in the row and cultivate as cabbage. One ounce for 3000 plants; three pounds per acre.

189-GREEN CURLED. Also called Siberian. Most tender and delicate of the cabbage family: improved by frost; leaves look like immense feathers which are curled on edges. Hardy. Pkt., 10c; oz., 15c; $1 / 4 \mathrm{lb} .30 \mathrm{c}$; lb. $\$ 1.00 ; 5$ lbs., \$4.00, postpaid.

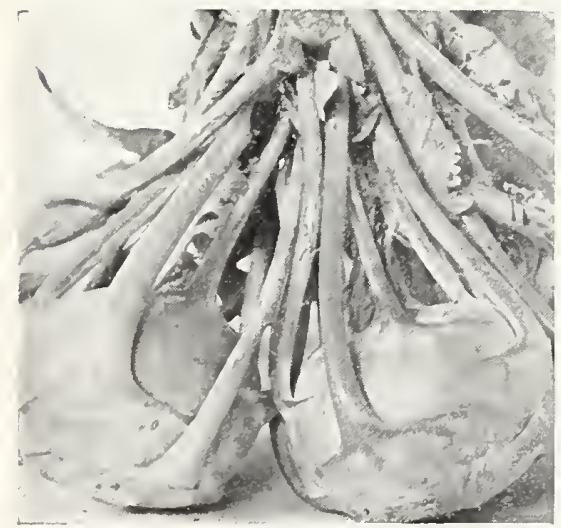

192-Kohl-rabi

\section{Nicholson's Superior Lettuce \\ (LECHUGA)}

For early spring use sow in September and protect through winter in cold frames as cab bage or sow in hotbeds in February, and transplant to open ground as soon as it can be worked. For late crop sow in open ground as soon as season permits, in rows 1 foot apart: in to one foot apart in rows.

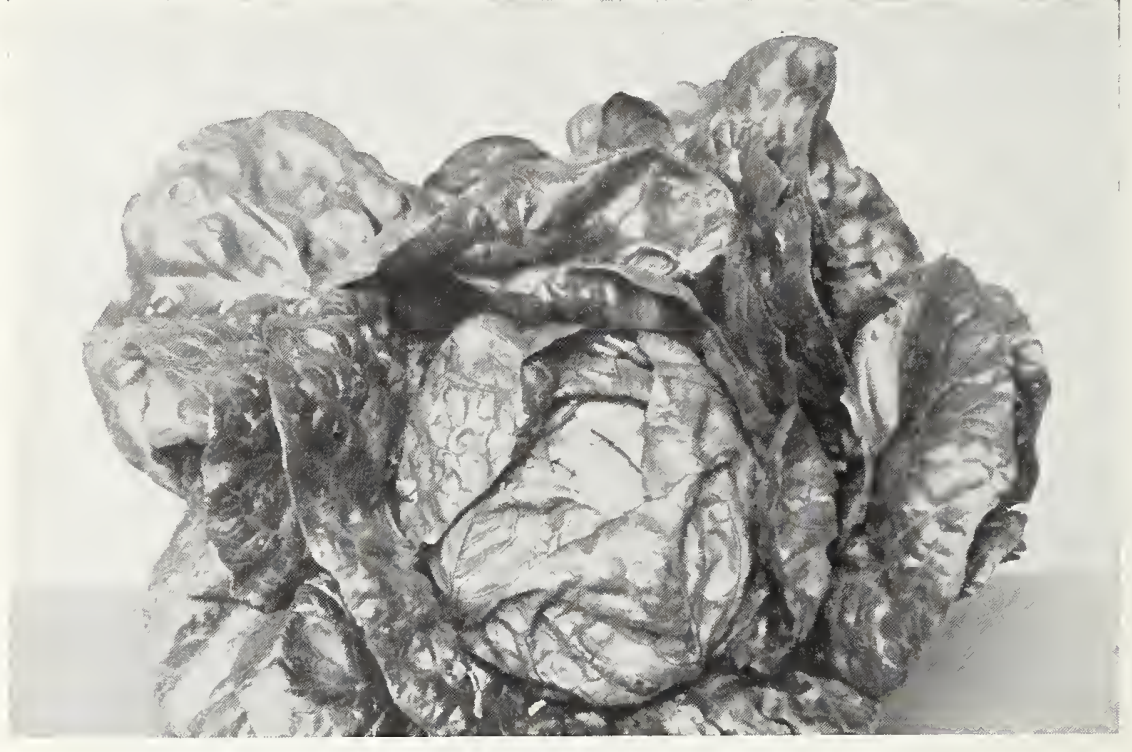

241-Lettuce-Nicholson's Big Boston

242-HANSON. This is a fine variety for late summer planting, as it stands the hot, dry weather and does not get bitter like some summer varieties; of fine quality and very popular. Pkt., 10c; oz., 20c; 1/4 lb., 50c; lb. $\$ 1.50 ; 5$ lbs., $\$ 6.00$, postpaid. Not prepaid, 10 lbs, or over at $\$ 1.00$ per lb.

245-BLACK-SEEDED SIMPSON. A bunching variety, forming no definite head. It has a large mass of fine, brittle leaves of a light green. Pkt., 10c; oz., 20c; $1 / 4$ lb., 50c; lb., $\$ 1.50$; 5 lbs., $\$ 6.00$, postpaid. Not prepaid, 10 lbs. or over at $\$ 1.00$ per lb.
243-ICEBERG. A large, crisp Lettuce, always tender. Iceberg stands hot weather remarkably well and is usually sown early in August for fall use. The color is light green, lightly tinged with brown. Pkt., 10c; 0z, 20c: 1/ lb, 60c. lb, \$1.75; 5 lbs, $\$ 7.00$, postpaid. Not prepaid, 10 lbs, or over at $\$ 1.25$ per lb.

244-PRIZEHEAD. One of the best loose, non-heading varieties, of fine quality and very popular. Pkt., 10c; oz., 20c; 1/4 lb., $50 \mathrm{c}$; lb. $\$ 1.50 ; 5$ lbs, $\$ 6.00$, postpaid. Not pre paid, 10 lbs. or over at $\$ 1.00$ per lb.

\section{Nicholson's Ideal Garden Collection-Postpaid}

Contains 15 most popular varieties for Southern Gardens

1 Pkt. Beans, Stringless Green Pod.

1 Pkt. Beans, Kentucky Wonder Pole.

1 Pkt. Beans, Kentucky Wonder Pole. 1 Pkt. Parsley, Double Curled.

1 Pkt. Cantaloupe, Improved Rocky Ford

1 Pkt. Carrots, Half Long.

1 Pkt. Cucumber, Long Green.

1 Pkt. Lettuce, Big Boston.

1 Pkt. Mustard, Giant Curled. No changes allowed on this collection on account of greatly reduced prices.

\section{Kohl-rabi}

192-EARLY WHITE VIENNA. Bulbs grow to the size of an apple when ready for use. of a blue-whitish color, delicate cabbagelike flavor. Very easy to grow, and should be put in every garden. Pkt., 10c; oz., 25c; $1 / 4$ lb., $75 c$; lb., $\$ 2.50 ; 5$ lbs., $\$ 10.00$, postpaid.

\section{Leek}

A widely cultivated member of the Onion family. Sow early in spring in rows 12 to 15 inches apart, covering seed about $1 / 2$-inch.

198-BROAD LEAF An extensively used and very desirable variety. Broad leaf, with short but thick stems. Pkt., 10c; oz., 25c; $1 / 4$ lb., $75 \mathrm{c}$; lb., $\$ 2.50$, postpaid.
1 Pkt. Okra, Green Pod.

Pkt. Peas, Thomas Laxton.

1 Pkt. Radish, Early Scarlet Turnip White Tip. 1 Pkt. Squash, Early white Bush.

1 Pkt. Turnip Purple Top White Globe.

Pkt. Watermelon, Nicholson's Honey Boy.

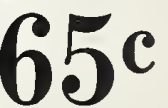

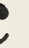




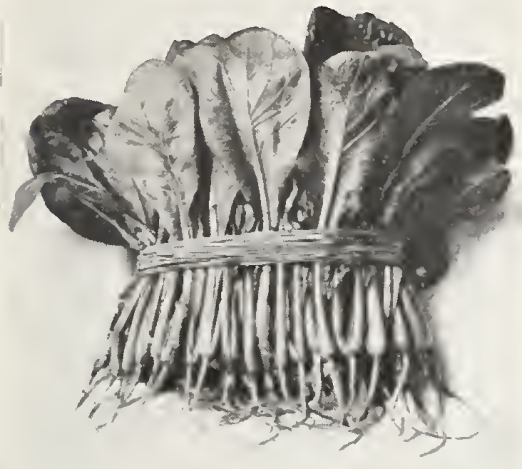

253-Japanese Mustard Spinach

252-LARGE SMOOTH LEAF. This wonderful variety has large, light green, plain or smooth leaves: this feature gives it a preference over the curled sorts as it is very easily prepared for cooking. The plant is of exceptionally quick growth, somewhat upright when young, becomes spreading at maturity. Home gardeners as well as truck growers should make a liberal planting of Large Smooth Leaf Mustard. Pkt., 5c; oz., l0c; 1/ lb., 25c; lb., 75c; 5 lbs., \$3.00, postpaid. Not prepaid, 10 lbs. or over at $50 \mathrm{c}$ per 16 .

\section{OKRA (Gombo)}

This vegetable is extensively grown for its green pods, and is used in soups. It has a zestful flavor particularly its own, and has gained a prominent place in the vegetable list.

255-DWARF GREEN LONG POD. Very early and productive. Pkt., 5c; oz., 10c; $1 / 4$ prepaid, 10 lbs. or over at $50 \mathrm{c}$ per lb.

256-WHITE VELVET. Pods large, white, very smooth. This distinct and beautiful sort originated in Georgia. Pkt., 5c; oz., 10c; 1/4 lb., 25c; lb., 75c; 5 lbs., $\$ 3.00$, postpaid. Not prepaid, 10 lbs, or over at $50 \mathrm{c}$ per $\mathrm{lb}$. ounce of seed will plant 200 feet of row.
250-NICHOLSON'S SOUTHERN GIANT CURLED. Large variety, forming a great mass of beautiful leaves, ruffled and finely curled on the edges. Pkt., 5c; oz., 10c; 1/4 lb. $25 \mathrm{c}$; lb. $75 \mathrm{c} ; 5$ lbs, $\$ 3.00$, postpaid. Not prepaid, $10 \mathrm{lbs}$. or over at $50 \mathrm{c}$ per lb.

251-NICHOLSON'S CHINESE BROAD LEA A very hardy broad-leaved variety. Leaves are thick and quite savoyed. The plant is of very quick growth, requiring about 30 days to mature. Sweetly pungent in flavor. Preferred by many as it is much easier to 5c; oz., 10c; $1 / 4$ lb., 25c; lb., 75c; 5 lbs., $\$ 3.00$ postpaid. Not prcpaid, 10 lbs, or over at $50 \mathrm{c}$ per lb.

253-JAPANESE MUSTARD SPINACH. A quick growing vegetable greens of Oriental origin. where it takes the place of spinach. It is practically an all-season plant and is ready for market about thirty days after planting. Withstands extreme summer heat in the South; also resistant to cold weather. The beautiful dark green oblong leaves are prepared for the table the same as spinach, mustard or turnip greens. The food content vegetable greens is growing in popularity and in time will replace to some extent the pounds of seed to the acre, 1 ounce to 100 feet of row. Pkt., 10c: oz., 15c; 1/1 lb., 35c lb., $\$ 1.00 ; 5$ lbs., \$3.75, postpaid. Not prepaid, 10 lbs. or over at 60 c per $1 \mathrm{~b}$.

257-PERKINS' LONG POD. A very prolific variety, pods intense green in color and of unusual length, very slim and do not get hard as other Okra. Pkt., 5c; oz., 10c; 1/4 lb., 25c; lb., 75c; 5 lbs., $\$ 3.00$, postpaid. Not prepaid, $10 \mathrm{lbs}$. or over at $50 \mathrm{c}$ per $\mathrm{lb}$.

258-TALL LONG GREEN. Pods are dark green and stalks tall. Pkt., 5c; oz., 10c; 1/s lb., 25c; lb., 75c; 5 lbs., $\$ 3.00$, postpaid. Not prepaid, $10 \mathrm{lbs}$. or over at $50 \mathrm{c}$ per lb. prepare for table than the curled sorts. Pkt., is exceptionally high. This wonderful new use of mustard and spinach. Sow about

\section{Mustard}

Ured as a condiment, and the green leaves are used as a salad, or cut and boiled like Prant, in very fine soil, in rows 6 inches apart. One

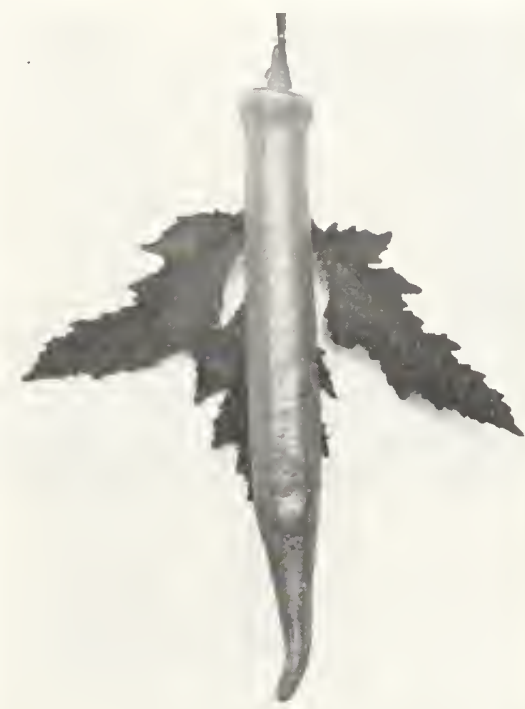

255-Dwarf Green Long Pod

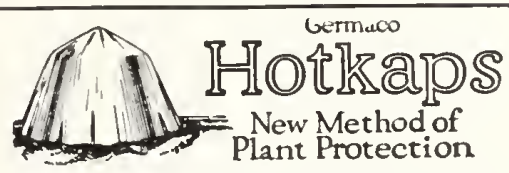

A money maker; matures crop earlier: shields plants from frost, wind and rain: protects them from insects miniature "hot-houses". See page 37 for description and prices.

\section{Muskmelons or Cantaloupes}

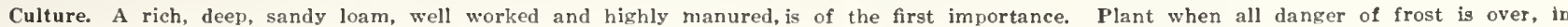

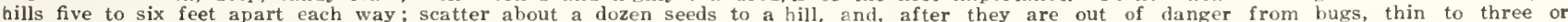

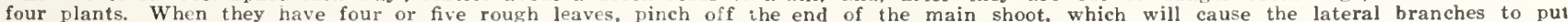

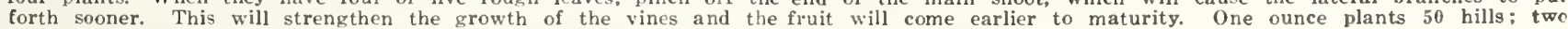
pounds plant one acre.

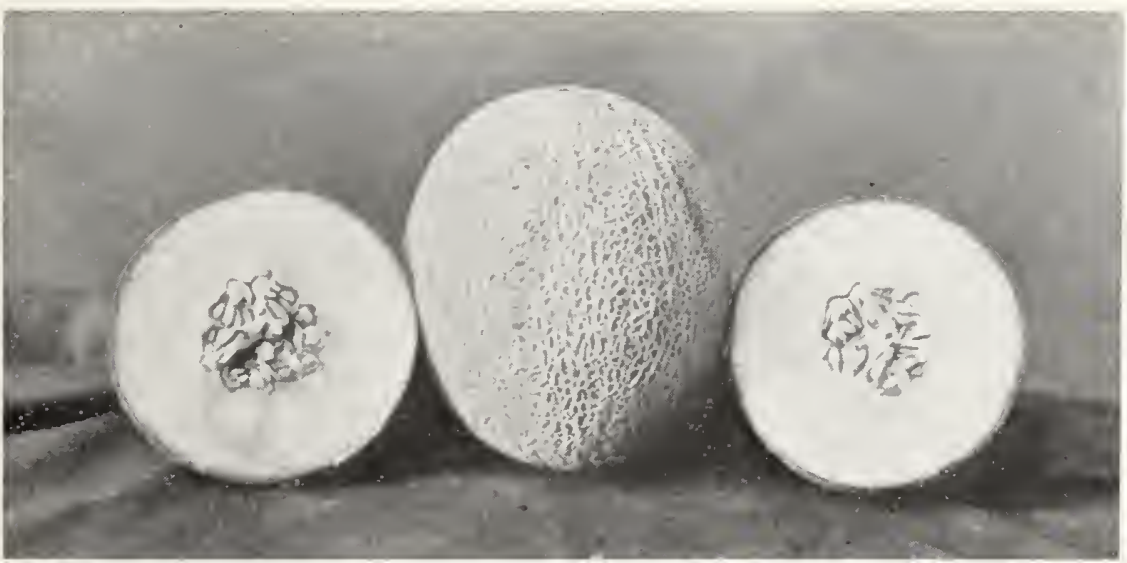

\section{8-Nicholson's Improved Perfecto}

This is an excellent Cantaloupe. The flesb is extremely thick, deep orange in color and fine in flavor, with a small triangular seed cavity. It is slightly oblong in shape, but at the same time it is almost round and is classed as a round Melon. The surface of the Melon is covered with a heavy gray net. ting which insures its shipping qualities. We expect Improved Perfecto to become vers popular. The vines of this Cantaloupe grow very profusely and it is resistant to disease to a marked extent. Give this new variety s trial for home or market, it will please you. Pkt., 10c; oz., 15c; 1/4 lb., 40c; lb., $\$ 1.25$; 5 lbs., \$5.50, postpaid. Not prepaid, 10 lhs. mr over at $\$ 1.00$ per lb. 


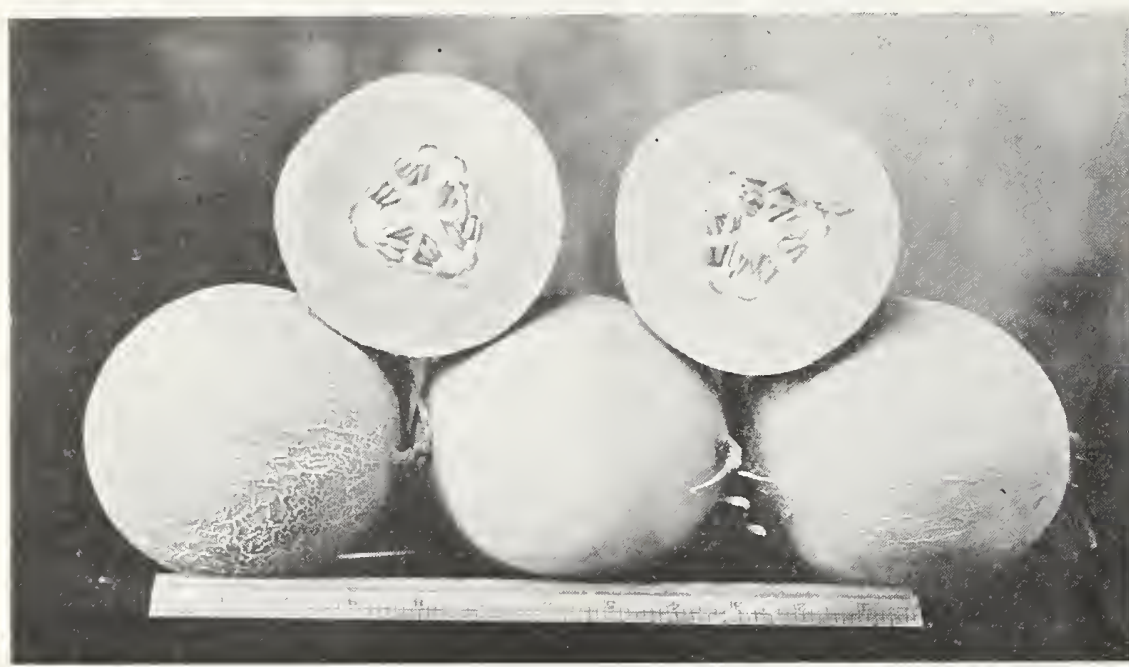

277-Nicholson's Honey Ball

265-NICHOLSON'S GOLD LINED ROCKY FORD. This is one of the finest Melons we handle. Flesh is green with a gold lining next to the seed cavity, making it unusually attractive when cut. Flesh very thick and spicy. Shape round with solid netting. This variety of Cantaloupe is grown for shipping very extensively by Colorado and California growers. Our seed is carefully selected from the best Melons. Pkt., 10c; 0z., 20c; 1/4 lb., 50c; lb. $\$ 1.50$; 5 lbs., $\$ 6.25$, postpaid. Not prepaid, 10 lbs. or over at $\$ 1.00$ per $l b$.

266-NICHOLSON'S SELECTED ROCKY FORD. The seed from this variety is gathered from selected stock. This Melon is unequaled in quality. The thick, green, sweet flesh is of the finest quality, with small, yellow cavity. Outer skin of Melon very heavily netted; Melons average an even medium size. Pkt., 10c; oz., 15c; $1 / 4$ lb., 40c; lb., \$1.25; 5 lbs., $\$ 5.00$, postpaid. Not prepaid, 10 lbs. or over at $85 \mathrm{c}$ per $1 \mathrm{~b}$.

268-BURRELL'S GEM. Sometimes called Pink-Meated Rocky Ford. Meat rich golden color, very thick, and of fine grain, and good flavor; covered with a closely laced gray netting, excepting the narrow stripes between the ribs, which are not netted. Oblong shape. Pkt., 10c; oz., 15c; 1/4 lb., 40c; lb., \$1.25; 5 lbs., $\$ 5.00$, postpaid. Not prepaid, $10 \mathrm{lbs}$, or over at $85 \mathrm{c}$ per $\mathrm{lb}$.

272-TEXAS CANNON BALL. Perfectly round, heavily netted. Flesh green and very thick. Small seed cavity. Pkt., 10c; oz., 20c; $1 / 4$ lb., 40c; lb., $\$ 1.25 ; 5$ lbs., $\$ 5.00$, postpaid. Not prepaid, 10 lbs. or over at 90c per lb.

276-POLLOCK 10-25 ROCKY FORD. Very uniform in size and shape and does not develop soft spots like some other varieties. Flesh is sweet and delicious, very deep and fine grained. The seed cavity is exceedingly small. Netting is heavy and even from stem to blossom. Matures early and is rust resistant. Cuts with a golden center, shading to a light green with a salmon tint near the rind, and is by all odds the best Cantaloupe yet introduced. Pkt., 10c; oz., 15c; Not prepaid, $10 \mathrm{lbs}$. or over at $\$ 1.00$ per $\mathrm{lb}$.

267-NICHOLSON'S SELECTED NETTED ROCK. A prolific yielder, matures early, rust resisting, with light gray, heavy netting. Fruit is ideal shape and size with flesh sweet, thick, juicy: fine flavor and small cavity. Pkt., 10c; oz., 15c; 1/4 lb., 40c; lb.. \$1.25; 5 lbs., $\$ 5.00$, postpaid. Not prepaid, $10 \mathrm{lbs}$. or over at 85 c per lb.
273-HACKENSACK. This is the old-
ashioned, large variety of Muskmelon, and still very popular. Deep ribbed, heavily netted, flesh thick and of fine quality. Pkt., 10c; oz., 20c; 1/4 lb., 35c; lb., \$1.00, postpaid.

\section{7-Nicholson's Honey Ball}

We introduced this wonderful Melon and it is now being planted from California to Florida, and as far north as the length of season will allow it to mature. It is the result of a cross between the Texas Cannon Ball and the Honey Dew. The Melons are round as a ball, slightly netted, and have a very thick wall of delicious green meat clear to the rind. It is very prolific, and resistant to drought and disease. The rind is hard and tough, making it a splendid shipper. The Melons are greenish white, turning to an attractive light yellow when fully ripe. Pkt., 10c; 0z., 20c; $1 / 4$ lb., 50c; lb., $\$ 1.50$; 5 lbs., $\$ 7.00$, postpaid. Not prepaid, $10 \mathrm{lbs}$. or over at $\$ 1.25$ per $1 b$.

269-HONEY DEW. The flesh is an emerald-green, very thick and fine grained; can be eaten to the rind. It is medium size, weighing 5 to 6 pounds. One of the best keepers, which makes it of special use to large growers, as they can be kept until winter months for marketing, when prices are high. Pkt., 10c; oz., 20c; 1/4 lb., 50c; lb., \$1.75; 5 lbs., $\$ 7.00$, postpaid. Not prepaid, $10 \mathrm{lbs}$. or over at $\$ 1.25$ per lb.

270-GOLDEN BEAUTY CASABA MELON. Grown very extensively in California. Do not pull until the light streaks on rind become yellow-store away in a dark, cool place so they will not touch each other. When the rind becomes slightly softened and moist they are ready to eat. Pkt., 10c; oz., 25c; $1 / 4$ lb., 75c; lb., \$2.50, postpaid.

271-HEARTS OF GOLD. A splendid Melon, either for the market or to grow for home use. Runs very uniform in size, oval to oblong in shape, and grows a little larger than our Rocky Ford variety. The Melons are heavily netted, and only slightly ribbed. The seed cavity is small. The flesh is a rich orange color, very fine grained, and has a delicious flavor. The vines are rust resistant. Pkt., 10c; oz., 20c; 1/4 lb., 40c; lb., $\$ 1.25 ; 5$ lbs., \$5.50, postpaid. Not prepaid, $10 \mathrm{lbs}$. or over at $\$ 1.00$ per $1 b$.

275-HALE'S BEST. A new Cantaloupe from the Imperial Valley of California Very early and fine for long distance shipping. Salmon flesh of exceptional thickness, the shape is oval, with heavy netting and prominent ribs. Pkt., 10c; oz., 20c; 1/4 lb., 40c; lb., $\$ 1.25: 5$ lbs., $\$ 5.50$, postpaid. Not prepaid, 10 lbs. or over, at $\$ 1.00$ per lb.

274-NICHOLSON'S IMPROVED BANANA MUSKMELON Grows from 1 to 2 feet long and ripens in about 85 days. Prolific bearer. Splendid flavor. One Melon enough to supply a family. Pkt., 10c; oz., 20c; $1 / 4$ lb., 50c; lb., \$1.50, postpaid.

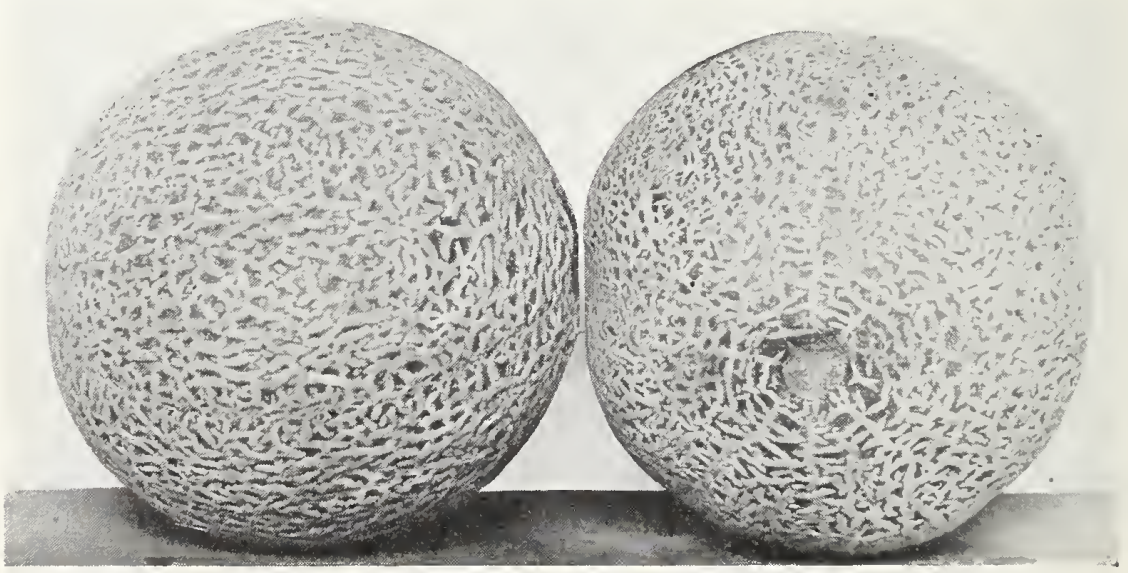

276-Pollock 10-25 Rocky Ford. 


\section{Tested seeds for}

\section{Nicholson's}

Famous Southern Grown

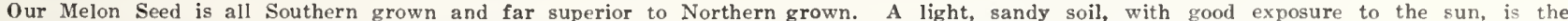

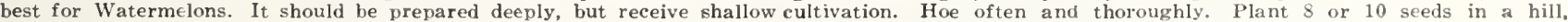

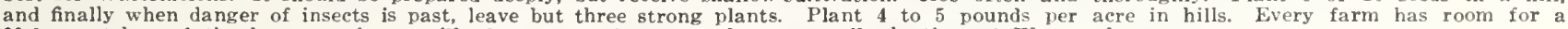
Melon patch, and the home gardener will also get good returns from a small planting of Watermelons.

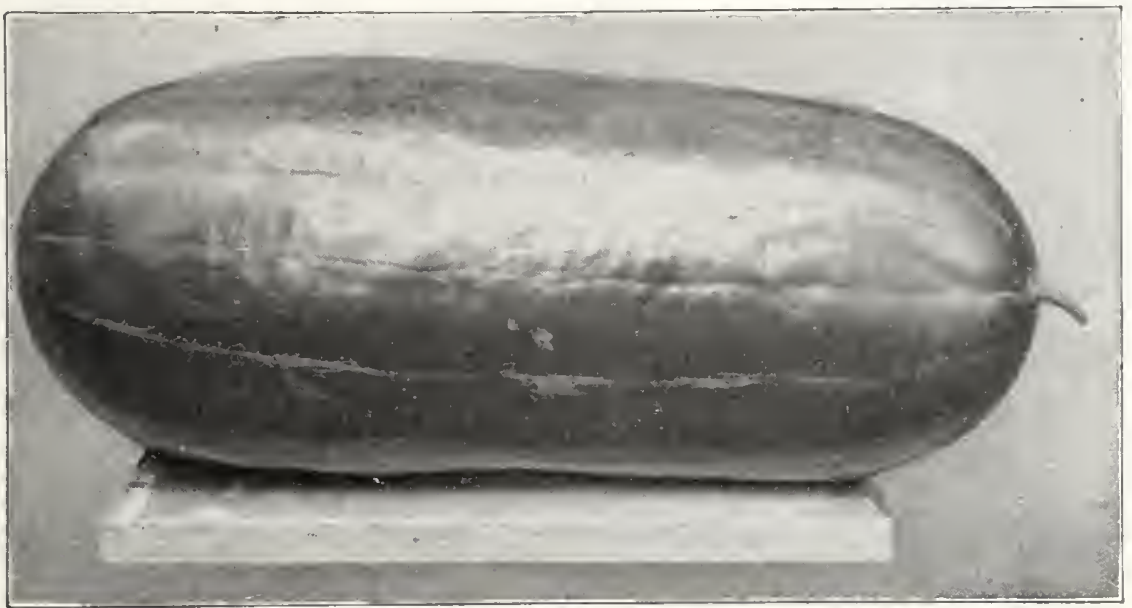

291-Nicholson's Honey Boy

\section{Nicholson's Wonder}

285-NICHOLSON'S WONDER. In shape iarge and long, somewhat resembling the Watson, only thlcker. The color is a dark solid green. The rind is thin hut tough. The flesh is red, heart solid, and does not show a hollow. Is an exceptionally fine eating Melon for home use and market. The seed is white, with but few in the Melon. Is extremely prolific. We recommend it very highly and feel sure our customers will be more than pleased with it. Pkt., 10c; oz. $15 c$; $1 / 4$ lb., $40 \mathrm{c}$; lb., $\$ 1.25 ; 5$ lbs., $\$ 5.00$, postpaid. Not prepald, 10 lbs, or over at $90 \mathrm{c}$ per lb.

286-IR1SII GREY. Flesh red crisp and sweet, free from stringiness. Color of rind mottled greenish grey; rind is thin but very toush. Vines very vigorous and hold up and produce Melons late in summer when other sorts die out; good shipper. Pkt., 10c; oz.. $15 \mathrm{c} ; 1 / 4$ lb., 40c; lb., $\$ 1.25$; 5 lbs., $\$ 5.00$, postpaid. Not prepaid, 10 lbs. or over at 75 per lb.

287-HALBERT HONEY. Average 18 to 24 inches long and are full or bluntly rour led at both ends. The skin is a dark glossy green. The flesh is a most beautiful erimson. the rich colorings and luscious quality extending to the thin rind. Popular for home gar. den and local market. Does well on black land. Pkt., 10c; oz., 15c; 1/4 lb., 40c; lb. $\$ 1.25$; 5 lbs., $\$ 5.00$ postpaid. Sot prepaid, $10 \mathrm{lbs}$. or over at $75 \mathrm{c}$ per lb.

288-GEORGIA RATTLESNAKE. This is still one of the best and most popular sorts. Has a thin tough rind and flesh is bright scarlet, very tender and sweet. Pkt., 10c; oz., $15 \mathrm{c}$; $1 / 4$ lb., $40 \mathrm{c}$; lb., $\$ 1.25 ; 5$ lbs., $\$ 5.00$, postpaid. Not prepaid, 10 lbs. or over at $75 e$ per lb.

290-COLORADO PRESERVING CITRON. Excellent for making preserves. Melons often weigh 20 pounds. Also used for feeding stock. Pkt., 10c; oz., 15c; 1/4 lb., 30c; !b, $\$ 1.00$, postpaid.

296-NICHOLSON'S GOLDEN HONEY. It is oblong, medium size. Flesh, beautifu' glistening amber shade, very tender, delicious flavor. Has no hard core or stringy sections. Recommended for home use. Pkt. 10c: oz., 15c; 1/4 lb., 40c; lb., \$1.25, postpaid.

\section{Nicholson's Honey Boy}

291-NTCHOLSON'S HONEY BOY. We in. troduced this wonderful Melon a few years ago. We believe it would be next to $1 \mathrm{~m}$ possible to find a better Melon for home use and short distance shipping. It grows uniformly large, long, thick and solid. weighing 40 to 50 pounds, and every Melon a good one. The flesh is sparkling red, very street, and delicious flavor. Color of rind dark, glossy green. Small creaselike markings on it make it very attractive in appearance. Seeds are broad, pearly white. The eating qualities of this Melon are unexcelled. The large heart of sparkling red color is very sweet and melting, absolutely free from cores or hard center. While the rind is thin, it is sufficiently tough to insure satisfactory shipping to reasonable distance. Pkt., 10c; oz., 20c; $1 / 4$ prepaid, 10 lbs. or over at $\$ 1.25$ per lb.

297-TOM WATSON. Is very large; rind thin but exceedingly tough; skin dark mottled green; flesh brilliant scarlet and the heart is very large. The flavor is delicious. The beauty of Tom Watson is its rind, whicn, together with its size, makes it ideal for shipping and handling, Pkt, 10c; oz. 15c; $1 / 4$ lb., 30c; lb., $\$ 1.00 ; 5$ lbs., $\$ 4.50$, postpaid. Not prepaid, $10 \mathrm{lbs}$. or over at $70 \mathrm{c}$ per $1 \mathrm{~b}$. Ask for prices on larger quantities.

298-KLECKLY or GEORGIA SWEET. Immensely popular because of its superb flavor and surpassing crispness; is not recommended for shipping, but for nearby markets and for home consumption it has no superior. Medium size, oval shape, average length about 18 to 20 inches; color, mottled green; flesh, bright red and of fine quality. Pkt., 10c; oz., 15c. $1 / 4$ lb. 40c; lb., \$1.25; 5 lbs., $\$ 5.00$, postpaid. Fot prepaid, 10 lbs. or over at 75 c per 1 b.

300-PARKER COUNTY TOM WATSON. Parker County has earned a splendid reputation for the fine quality and large size Tom Watson Melons it produces. Our seeds are saved from the largest and best Melons, and we believe they are as good as any you can buy anywhere, at any price. Many of our largest Melon growers will plant no other kind. Pkt., 10c; oz., 20c; 1/4 lb., 60c; lb., kind. Pkt., 10c; oz., 20c; 1/4 lb., 60c; lb.,
$\$ 2.00 ; 5$ lbs., $\$ 8.75$, postpaid. Not prepaid, 10 lbs. or over at $\$ 1.50$ per lb. oz., 20c; $1 / 4$ lb., $50 c$ postpaid. Not prepaid, 10 lbs, or over $\$ 1.25$ per $1 \mathrm{~b}$.

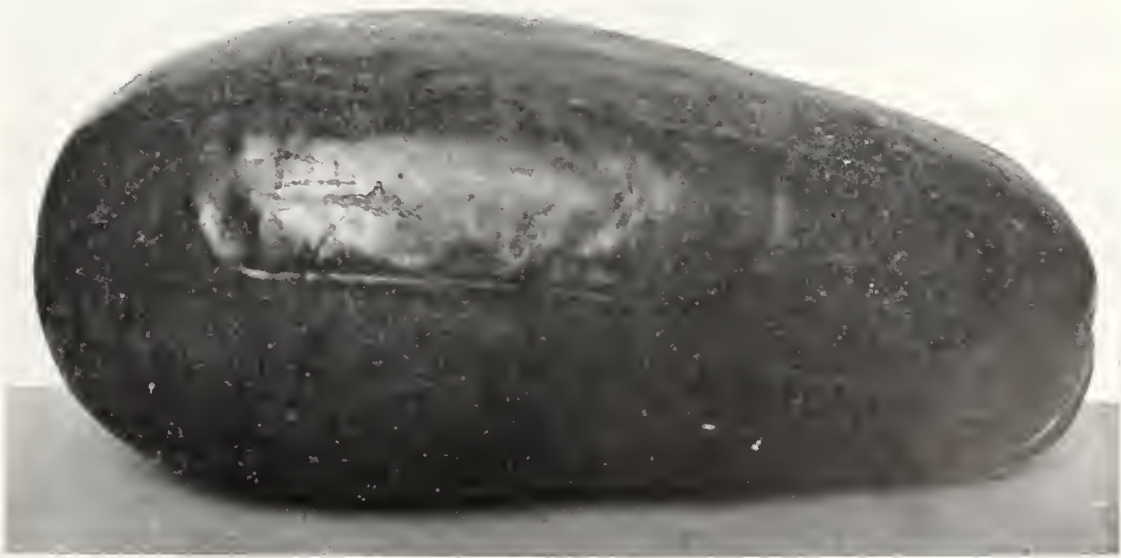

287-Halbert Honey 


\section{Robert Nicholson}

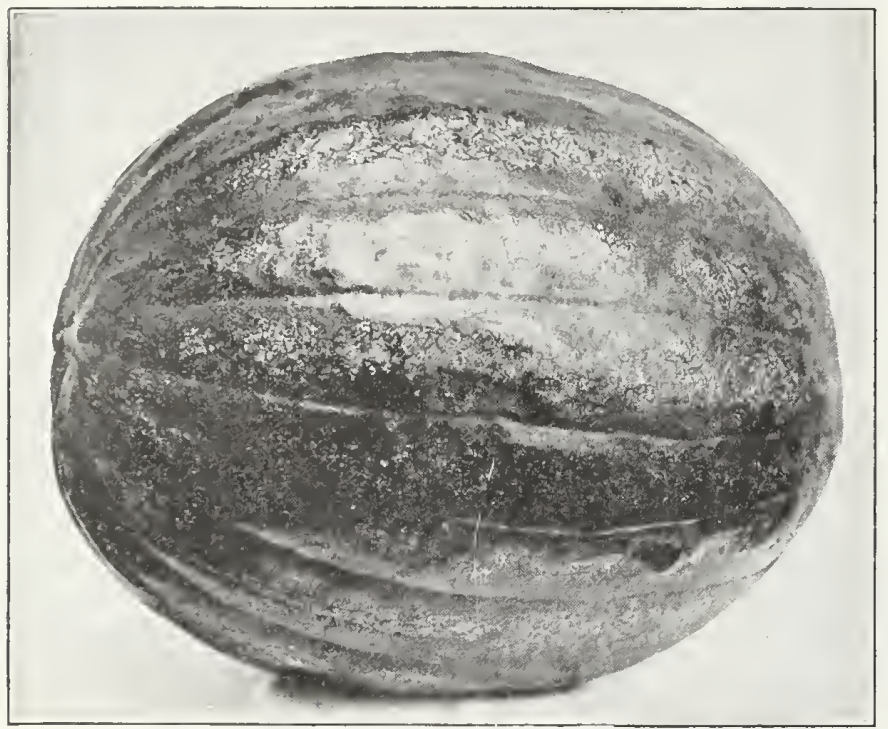

zys-stove wountain watermeion
299-DONNER'S IMPROVED KLONDIKE. Among the leading shippers in all the Melon growing districts of California this wonderful new Melon has rightfully earned the reputation of being the best quality shipping Melon in existence, and is being grown with equal success in other States regardless of climatic conditions. The Melons are oblong in shape, and weigh from 20 to 35 pounds each. The rind is thin but tough, with an attractive deep green color. The flesh of the Melon is a rich red. It is without doubt one of the sweetest Melons grown. Pkt., 10c; oz., 20c; 1/4 lb., 60c; lb., \$2.00; 5 lbs., \$8.75, postpaid. Not prepaid, 10 lbs. or over, \$1.50 per lb.

292-NICHOLSON'S PORTO RICO WATERMELON. This is our orange flesh Melon, and is superior in every way to any other orange or yellow meat variety now on the market. In appearance the Melons are long and somewhat pear-shaped, being small at the stem end, and are very uniform in size and shape. The rind is dark green striped with a lighter green and the flesh a beautiful orange color, very sweet and tender. You will find this wonderful Melon to be one of the best varieties for the home garden that has ever been introduced. Pkt., 10c; oz., 20c; 1/4 lb., 50c; lb., $\$ 1.50 ; 5$ lbs. $\$ 7.00$, postpaid. Not prepaid, 10 lbs. or over at $\$ 1.25$ per lb.

293-STONE MOUNTAIN. Undoubtedly one of the very best of Melons. It is extra large, weighing as much as 75 to 80 pounds if carefully cultivated; is round or nearly round in shape, with a beautiful dark green rind; the flesh is an attractive scarlet color, and as delicious as any you ever tasted. We know that Stone Mountain is sure to satisfy as a home garden variety, and with careful packing in straw can be easily shipped or hauled to market, and when once on the market will outsell any other variety. Extra select seed. Pkt., 10c; oz., 20c; 1/4 lb., 50c; lb., $\$ 1.50$; 5 lbs., $\$ 6.00$, postpaíd. Not prepaid, 10 lbs. or over at $\$ 1.00$ per $1 b$.
Kearney County, Neb.

The Honey Boy is some watermelon. We had wonderful success with it. The Honey Boy does great in this section of the country.

Charles Golay.

\section{Aransas County. Texas.}

I thank you for the good fresh Water. melon seed. You have them all bested when it comes to mailing seeds. My field seeds also came through in a hutry. Very truly yours.
Bee County, Texas.

We get mote and better seed for the money from Robert Nicholson Seed Co. than anywhere else.

Yours truly,

MRS. J. C. HARRIS.

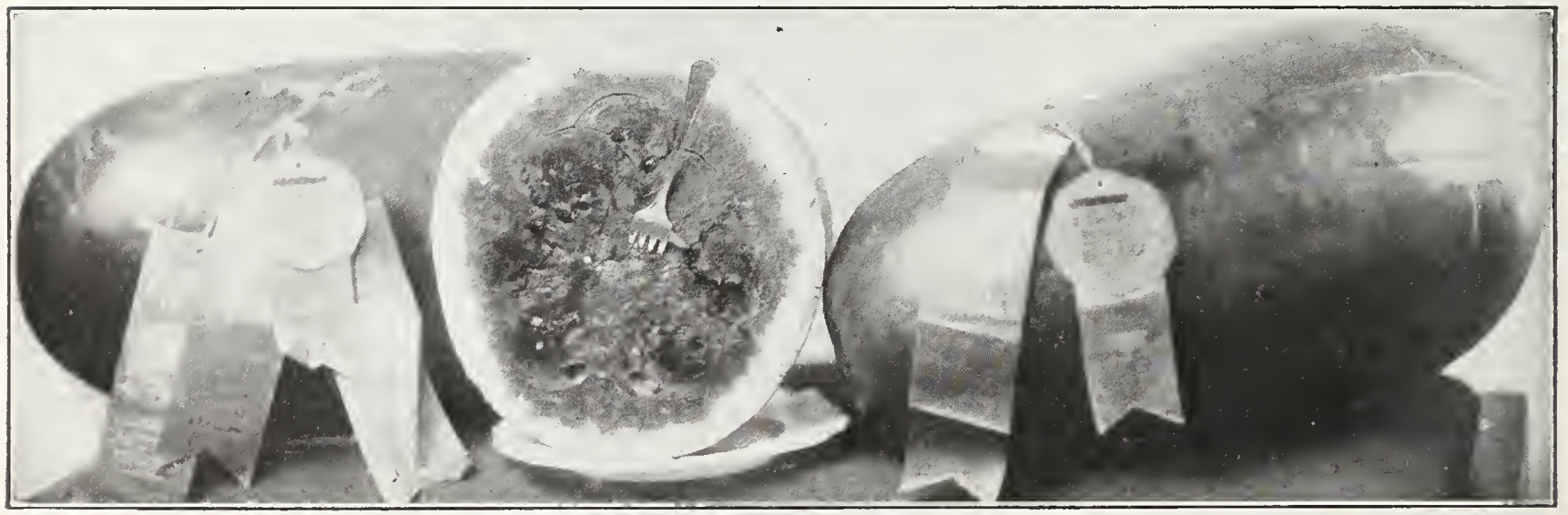

299-Donner's Improved Klondike

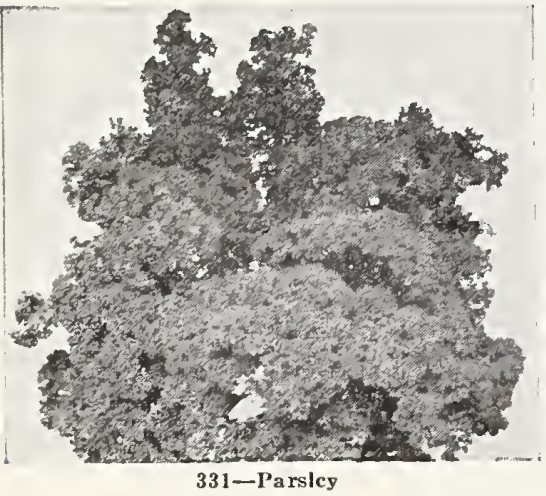

\section{Parsley}

(PEREJIL)

Parsley is used as a garnishment for meat and salads and also adds a pleasing flavor to soups. Soak seed for several hours previous to sowing, in warm water, which will facilitate germination. Sow in border or frame. Thin rows to 8 inches each way. One ounce of seed to 150 feet of drill.

351-DOUBLE CURLED. Standard variety: curled leaves; finest quality. Pkt., 5c; oz., 20 c; $1 / 4$ lb., 35c; lb., $\$ 1.00 ; 5$ lbs., $\$ 4.00$, postpaid. Not prepaid, 10 lbs. or over at $65 \mathrm{c}$ per lb.

\section{Parsnips}

\section{(CHIRIVIA)}

The value of the Parsnip as a culinary vegetable is well known but it is not generally appreciated at its full value for stock feeding. Work the soil very deeply and pulverize the surface thoroughly. Sow the seed in early spring, one-half of an inch deep, in rows 12 to 18 inches apart. One ounce of seed for 200 feet of row; five pounds per acre.

353-LARGE SUGAR OR H OLL O W CROWN. The young, tender roots are fine for table use, and when they are full grown they make valuable stock feed. Pkt., 5c; oz., $15 \mathrm{c} ; 1 / 4 \mathrm{lb} ., 35 \mathrm{c} ; \mathrm{lb}$., $\$ 1.00$, postpaid. 


\section{Nicholson's Tested Onion Seed}

If planting for big Onions sow one ounce of seed to 60 to 75 feet of drill, or $2 \frac{1 / 2}{2}$ to 3 pounds per acre, in rows 12 to 15 inches apart; for best results in growing large Onions, after they begin to bowl, carefully draw the dirt away from the Onion until bowl is covered about one-fourth inch, then take your garden hoe and smash the tops over on the ground; by doing this the strength all goes to the bowl and it develops very rapidly. If planting for green Onions, it requires about one ounce of seed to 25 or 30 feet of drili.

\section{5 - NICHOLSON'S GIANT WHITE}

GLOBE. This variety yields abundantly, producing medium to large, handsome, and finely shaped, clear white, globe-shaped bulbs. The flesh is firm, fine grained and mild in flavor. Pkt., 10c; oz., 25c; 1/4 lb., 75c; lb., $\$ 2.50$; 5 lbs., $\$ 12.00$, postpaid. Not prepaid, $10 \mathrm{lbs}$. or over at $\$ 2.25$ per $1 \mathrm{~b}$.

306-AUSTRALIAN BROWN. Extra early, sure cropper, and extra long keeping. Resembles Danvers in size and form, but are thicker and mature earlier. Bright reddish brown; flesh white, crisp, extremely solid and of sweet, mild flavor. Pkt., 10c; oz., 20 ; $1 / 4$ lb., 50c; lb., $\$ 1.85$; 5 lbs., $\$ 8.75$, postpaid. Not prepaid, 10 lbs. or over at $\$ 1.50$ per lb.

307 - N1CHOLSON'S GIANT YELLOW DENIA. An improved Yellow Prizetaker. A new Onion brought from Spain several years ago which is proving very popular. Very large, light yellow, globe-shaped, small top, wonderful shipper. Very mild and excellent flavor. Once tried always used again. Pkt. 10c: 02, 25c; 1/4 lb., 75c; lb., \$2.35; 5 lbs. $\$ 11.25$, postpaid. Not prepaid, 10 lbs. or over at $\$ 2.00$ per $1 \mathrm{~b}$.

309 - N1CHOLSON'S EARLY WH 1 T E PEARL. Makes a fine, large, flat Onion of mild flavor. Very popular with market gardeners and one of the finest Onions for home use. Pkt., 10c; oz., 25c; 1/4 lb., 75c; lb. $\$ 2.50$; 5 lbs., $\$ 12.00$, postpaid. Not prepaid, 10 lbs. or over at $\$ 2.25$ per lb.

315-MAMMOTH S1LVER K1NG. No other white Onion attains such mammoth size. The bulbs are of an attractive shape, flat but thick. Mammoth Silver King is mild in flavor and an excellent keeper. Pkt., 10c; oz., 25c; $1 / 4$ lb., $75 \mathrm{c}$; lb., $\$ 2.50$; 5 lbs., $\$ 12.00$, post paid. Not prepaid, 10 lbs. or over at $\$ 2.25$ per lb.

312 - RED CREOLE. Very popular in Louisiana: fine keeper. Pkt., 10c; oz., 25c : 1/4 Ib., 75c; lb., \$2.50, postpaid.

313-NICHOLSON'S NEW G1ANT SWEET SPANISH VALENC1A. Grows a little larger than the Prizetaker, globe-shaped, of light yellow color, very mild in flavor and quite uniform in shape-a good yielder and a uniform in shape-a good yielder and a
splendid keeper. Pkt., 10c; oz., 30c; $1 / 4$ lb., $\$ 1.00$; lb., $\$ 3.50 ; 5$ lbs., $\$ 16.50$, postpaid. Not prepaid, 10 lbs, or over at $\$ 3.00$ per lb.

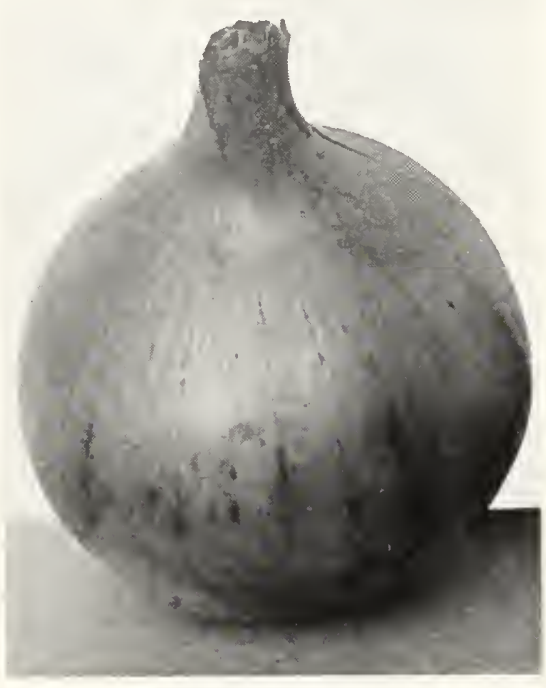

313-Sweet Valencia

314-WH1TE PORTUGAL or SILVER SK1N. Very hard and firm and an excellent sets and pickles. Pkt., 10c; oz., 25c; 1/4 lb. $85 \mathrm{c}$; lb., $\$ 3.00$; 5 lbs., $\$ 14.25$, postpaid. Not prepaid, 10 lbs, or over, $\$ 2.75$ per $\mathrm{lb}$.

316-GIANT YELLOW PRIZETAKER. One of the most profitable Onions to plant in Central and North Texas. Bright straw color, mild flavor, and grows to enormous size: a good keeper and shipper. Pkt., 10c: oz., 25 c; $1 / 4$ lb., 60c; lb., $\$ 2.00 ; 5$ lbs., $\$ 9.25$, postpaid. Not prepaid, 10 lbs, or over a $\$ 1.75$ per lb.

308-RED WETHERSFIELD. Color, deep and very firm. Pkt., 10c; oz., 25c; 1/4 lb., 60 ; lb., \$2.00; 5 lbs., \$9.50, postpaid. Not prepaid, 10 lbs. or over at $\$ 1.75$ per $1 b$ keeper. Largely used for white Onion purplish red, flesh white, moderately grained
317-WH1TE CREOLE. A dandy white onion. A native of the State of Louisiana. Pkt., 10c; oz., 25c; $1 / 4$ lb., 75c; lb., \$2.50, postpaid.

\section{Nicholson's Bermuda Onion Seed}

Bermuda Onions are too well known in the South to require an extensive description We import direct from the most reliable grower in the Canary Islands large quantities of seed especially grown for us on contract. It is the earliest, mildest and most attractive Onion on the American market.

311 - YELLOW BERMUDA. Sometimes called White Bermuda. 1t is of light straw color. This is a thin, flat Onion of medium size and very sweet; many people eat them like an apple. Pkt., 10c; oz., 25c; 1/4 lb. 65 ; lb., $\$ 2.25$; 5 lbs., $\$ 10.50$, postpaid. Please write for prices in larger lots.

310-CRYSTAL W11TE WAX BERMUDA The most popular of the Bermuda Onions. It is a clear, waxy white Onion and has the delightful mild flavor of the Yellow Bermuda. Like the Yellow Bermuda, it is a flat Onion of medium size. Pkt., 10c; oz., 25c; 1/4 lb. $65 c$; lb., $\$ 2.25$; 5 lbs., $\$ 10.50$, postpaid. Please write for prices in larger lots.

\section{Nicholson's Selected Onion Sets}

Plant plenty of Onion sets in the spring.

RED. Lb., 35c; 3 lbs., 90c, postpaid. Not prepaid, 8 lbs. (peck), $\$ 1.00$; bu. (32 lbs.) $\$ 3.50$.

WH1TE SILVERSKIN. Lb., 35c; 3 lbs., $90 \mathrm{c}$, postpaid. Not prepaid, 8 lbs, (peck) $\$ 1.15$; bu. (32 lbs.), $\$ 4.00$.

YELLOW, Lb. 35c; 3 lbs, 90c, postpaid Not prepaid, 8 lbs. (peck), \$1.00; bu. (32 lbs.), $\$ 3.50$

GARLIC. Large, healthy bulbs for plant ing. Lb. 25c, 5 lbs. \$1.00, postpaid.

Falls County, Texas.

Please permit me to say I am well pleased with past order of seeds from you and I think your catalog is a wonderful help to vegetable and flower growers.

\section{Yours truly.}

H. E. KELLY.

\section{TREAT YOUR ONION SEED}

Destroy surface-borne onion seed disease and prevent rotting in the soil by dusting seed with $3 / 4$ ounce of Semesan to 15 pounds of seed or by soaking them for one hour in normal liquid Semesan. 1ncreases germina tion, stand, vigor of plants and yield. Ask for Semesan Vegetable Booklet. Typical re sults obtained by growers below:

"We treated with Semesan one-half of lot of low-grade onion seed, germinating only $30 \%$. The Semesan-treated seed germinater $75 \%$ while the untreated seed molded. In other words, Semesan increased germination $150 \%$.

"We increased the germination of onion seed $50 \%$ by Semesan disinfection."-Auror Seed Mills, Stockton, California.

"We treated a thousand pounds of onion seed last spring with Semesan. We have one of the best crops "n our section."

See announcement on page 66 . 


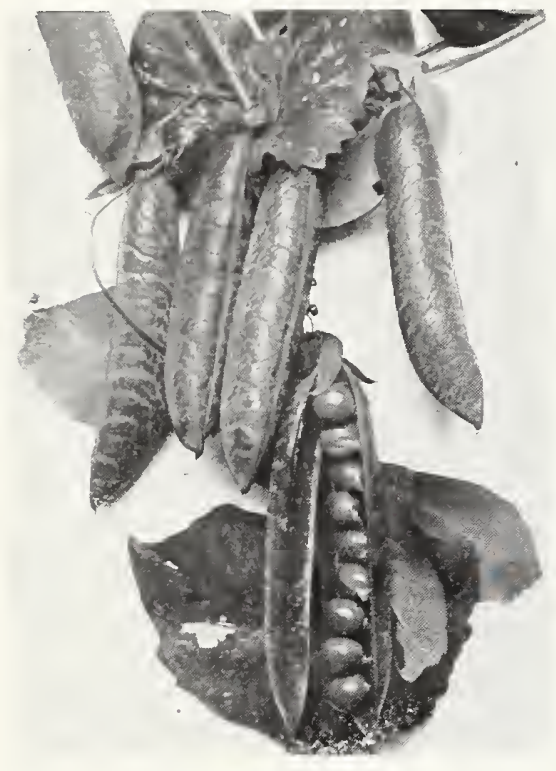

324-Thomas Laxton

\section{Later Varieties}

330-BLISS EVERBEARING. As the name indicates, this variety continues long in bearing and is very prolific: is very desirable for late summer and autumn plantng. Height about 3 feet. Pkt,. 10c; 1/2 lb., 20c; lb., 40c; 2 lbs., 75c; 5 lbs., \$1.75, postpaid. Not prepaid, 20 lbs., \$3.60; 50 lbs., \$8.75; 100 lbs.. $\$ 17.00$.

331-CHAMPION OF ENGLAND. One of the best tall, wrinkled varieties known for late spring and summer planting: very prolific. Height $3 \frac{1}{2}$ to 4 feet. Pkt., 10c; 1/2 lb., 20c; b., 40c; 2 lbs., 75c; 5 lbs., \$1.75, postpaid. Not prepaid, 20 lbs., $\$ 3.60 ; 50$ lbs., $\$ 8.75 ; 100$ lbs., $\$ 17.00$.

320-IMPROVED TELEPHONE. One of the leading large-podded varieties. Pods 5 to 51/2 inches long, and broad and straight, well filled with large Peas of delicious flavor. Pods are dark green and retain their color a long time after pickling. Vines grow about 40 inches high. Pkt., 10c; 1/2 lb., 20c; lb., 40c; 2 lbs., 75c; 5 lbs., $\$ 1.75$, postpaid. Not prepaid, 20 lbs., $\$ 3.50$; 50 lbs., $\$ 8.50 ; 100$ lbs., $\$ 16.00$.

332-WHITE MARROWFAT. A very popular tall, smooth variety; large, well filled pods. Very delicious while young. One of the favorites for canning; will also produce large quantitics of dry Peas; fine for table use. Height 4 feet. Pkt., 10c; $1 / 2$ lb., 20c; lb., 40c; 2 lbs., 75c; 5 lbs., \$1.75, postpaid. Not prepaid, 20 lbs., $\$ 3.00 ; 50$ lbs., $\$ 7.25 ; 100$ lbs., $\$ 14.00$.

\section{Field Peas for Table Use}

333-LARGE WHITE BLACK-EYE. Although these are usually classed as field Peas, they are always in good demand for table use, either as "snaps" or as green or dry shelled Peas. Pkt., 10c; lb., 25c; 2 lbs., 45c; 5 lbs., \$1.00, postpaid. Not prepaid, 20 lbs., \$1.75. Ask for prices on larger quantities.

334-BROWN CROWDER. A very fine, large variety of field Pea, excellent for table use when green. Pkt., 10c; lb., 25c; 2 lbs. $45 \mathrm{c} ; 5$ lbs., $\$ 1.00$, postpaid. Not prepaid, 20 lbs., \$1.50. Ask for prices on larger quantities.

WH1TE CROWDER. A delightfully flavored variety for table use. We have a limited supply this year. Pkt., 10c: lb., 30c; 2 lbs., 55c; 5 lbs., $\$ 1.25$, postpaid. Not prepaid, 20 lbs., $\$ 2.50$. Please write for prices in larger lots.

\section{Nicholson's Tested Garden Peas}

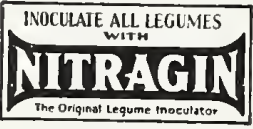

Peas are one of the most valuable of the garden crops. Should be planted as early as the ground can be worked, in double rows 8 to 10 inches apart; two pounds of seed to 100 feet of drill, 11/2 bushels per acre. Xou will have the best results with early Peas on light, warm soil, but the main crop will do better on a fairly heavy soil that will retain moisture. Inoculate Peas with Nitragin before sowing. For prices, see page $\mathbf{5 5 .}$

First Early Varieties

326-FIRST AND BEST. Very early and prolific; does not ripen as evenly as some others, and is, therefore, highly recommended for family use. Height about two feet. Pkt., $10 \mathrm{c}$; $1 / 2 \mathrm{lb}$., $20 \mathrm{c}$; lb., 40c; 2 lbs., $75 \mathrm{c}$; 5 lbs., $\$ 1.75$, postpaid. Not prepaid, 20 lbs., $\$ 3.00$; 50 lbs., $\$ 6.50 ; 100$ lbs., $\$ 12.50$.

327-EARLY ALASKA. The earliest Pea grown It is a smooth, round, blue Pea; the plants grow about two feet high. This is a good variety for gardeners, as they ripen very rapidly and are heavy yielders. Pkt., 10c; 1/2 lb., 20c; lb., 40c; 2 lbs., 75c; 5 lbs., $\$ 1.75$, postpaid. Not prepaid, 20 lbs., $\$ 3.00$; 50 lbs., $\$ 6.50 ; 100$ lbs. $\$ 12.50$.

\section{Second Early Varieties}

336-LITTLE MARVEL. This is a most desirable Pea for the home garden. The very dark green vines are about 18 inches high, very sturdy and vigorous, and loaded with pods. The pods are very deep green about three inches long, blunt ended and closely packed with Peas of medium size. The Peas are extremely tender and unsurpassed in sweetness. It is only a few days later than the earliest Peas, so should be planted as the main erop in any garden. Pkt., 10c; 1/2 lb., 20c; lb., 40c; 2 lbs., 75c; 5 lbs. $\$ 1.75$, postpaid. Not prepaid, 20 lbs., $\$ 3.50 ; 50$ lbs., $\$ 8.50 ; 100$ lbs., $\$ 16.00$.

324-THOMAS LAXTON."A very early wrinkled variety of merit. The vines are vigorous, of medium height, usually about 3 feet. The pods are large, often 4 inches long, similar to but larger, longer and darker than those of Champion of England. The green Peas are very large, of fine deep color and unsurpassed in quality. Pkt., 10c; 1/2 lb. 20c: lb. 40c: 2 lbs, $75 c$; 5 lbs. \$1.75, postpaid. Not prepaid, 20 lbs., $\$ 3.50$; 50 lbs. $\$ 8.50$; 100 lbs., $\$ 16.00$.

328-EARLY PREMIUM GEM. One of the earliest of the wrinkled varieties, pods well filled and of medium size; very desirable for home use. Height about 12 to 15 inches. Pkt., 10c; 1/2 lb., 20c; lb., 40c; 2 lbs., 75c; 5 lbs $\$ 1.75$, postpaid. Not prepaid, 20 lbs., \$3.50; 50 lbs., $\$ 8.50 ; 100$ lbs., $\$ 16.00$.

325-PRIDE OF THE MARKET. A medium dwarf variety; prolific; has large, well filled pods. Height about 20 to 24 inches. Pkt., $10 \mathrm{c}$; $1 / 2 \mathrm{lb}$., 20c; $1 \mathrm{~b} ., 40 \mathrm{c} ; 2$ lbs., $75 \mathrm{c}$ : $5 \mathrm{lbs}$., $\$ 1.75$, postpaid. Not prepaid, 20 lbs., \$3.60: 50 lbs., $\$ 8.75 ; 100$ lbs., $\$ 17.00$.

335-CREAM or LADY. One of the best of the field Peas to plant for table use; very sweet and deliciously flavored when green. Pkt., 10c; lb., 25c; 2 lbs., 45c; 5 lbs., $\$ 1.00$ postpaid. Not prepaid, 20 lbs., $\$ 1.75$. Ask for prices on larger quantities.

\section{Cloverdale, New Mex.}

Robett Nicholson Seed Co.,

Dallas, Texas.

Gentlemen:

The garden seed I bought from you were just fine.

\section{Very truly yours,}

MARY E. FULBRIGHT

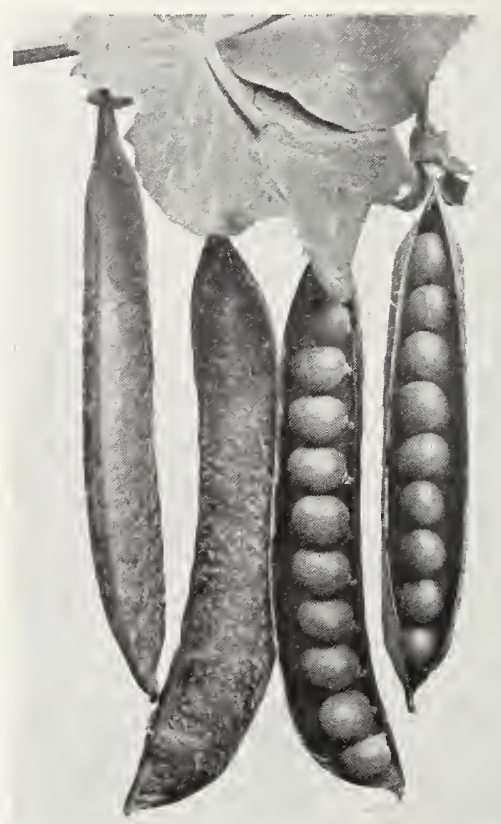

326-Little Marvel

321-DWARF TELEPHONE. Grows about 18 inches high, with pods very similar in size and shape to Improved Telephone. One of the best dwarf varieties. Pkt., 10c; $1 / 2$ lb., 20c; lb., 40c; 2 lbs., 75c; 5 lbs., $\$ 1.75$, postpaid. Not prepaid, 20 lbs., $\$ 3.60 ; 50$ lbs., $\$ 8.75 ; 100$ lbs., $\$ 17.00$

323-AMERICAN WONDER. Grows 10 to 12 inches high, is an abundant producer of fine flavored Peas. Pkt., 10c; 1/2 lb., 20c; lb., 40c: 2 lbs, 75c: 5 lbs., $\$ 1.75$, postpaid. Not prepaid, 20 lbs., $\$ 3.50 ; 50$ lbs., $\$ 8.50 ; 100$ lbs., $\$ 16.00$.

329-NOTT'S EXCELSIOR. A dwarf variety. The vines are vigorous, growing 12 to 15 inches in height; very desirable as a second planting. Pkt., 10c; 1/2 lb., 20c; lb., $40 c$ : 2 lbs. $75 c$; 5 lbs. \$1.75, postpaid. Not prepaid, 20 lbs., $\$ 3.50$; 50 lbs., $\$ 8.50 ; 100$ lbs., $\$ 16.00$.

\section{Rape ("For Greens")}

362-RAPE A dwarf variety. Makes an excellent green for table use when young. Leaf somewhat like a collard, but seems to have a more delicate flavor. Pkt., 5c; oz., $10 c ; 1 / 4$ lb., 15c; lb., 25c, postpaid.

\section{Salsify}

\section{(Oyster Plant)}

A very desirable root vegetable. The flavor is very much like oysters. The roots will grow until frost and may then be left in the ground until ready for use. One ounce of seed will sow 100 feet of row. ISLANY. Good for both market and home garden. Pkt., $10 \mathrm{c}$; oz., 25c; 1/4 lb., 75c; lb., $\$ 2.25$; 5 lbs., $\$ 9.00$, postpaid. 


\section{Nicholson's Peppers}

\section{(PIMIENTO)}

It is easier than most people think to grow Peppers. The milder varieties are relished by

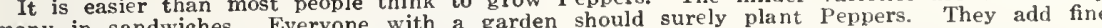
flavor to relishes, winter sauces and salads.

Culture. Plant seed one-half inch deep in hotbeds in March or in boxes in the house; when danger of frost is over transplant $11 / 2$ feet apart in rows 3 feet wide. One ounce of seed will produce 500 plants.

340-CALIFORNIA WONDER. We believe this Sweet Pepper to be one of the best. Similar in size and shape to the well known Chinese Giant variety, only slightly smaller. and is smoother and more meaty. Very at tractive in appearance, and easily qualifies tractive in shipping variety as an excellent market and shipping variety Pkt., 15c; 0z., 50c; 1/4 lb., $\$ 1.60 ;$ Ib., $\$ 6.00$; or over, $\$ 5.25$ per $1 b$.

341-CHINESE GIANT. One of the largest varieties of Sweet Peppers. The flesh is thick, tender, mild and sweet, and is unexcelled for salad or stuffed mangoes; they can be sliced and served raw like tomatoes. When ripe the Peppers are a rich, glossy scarlet, making them of unusually fine appearance. Pkt., 10c; oz., 50c; $1 / 4$ lb., $\$ 1.50$ lb. $\$ 5.50 ; 5$ lbs., $\$ 25.00$, postpaid. Not prepaid, 10 lbs. or over at $\$ 4.75$ per lb.

342-RUBY GIANT. Is a cross between Ruby King and Chinese Giant. It is very attractive grows to a very large size, and is exceptionally mild. When ripe is bright scarlet, flesh very thick, mild and of very fine flavor. Pkt., 10c; oz., 35c; 1/4 lb., $\$ 1.00$ lb., $\$ 3.50 ; 5$ lbs., $\$ 16.00$, postpaid. Not prepaid, 10 lbs, or over at $\$ 3.00$ per lb.

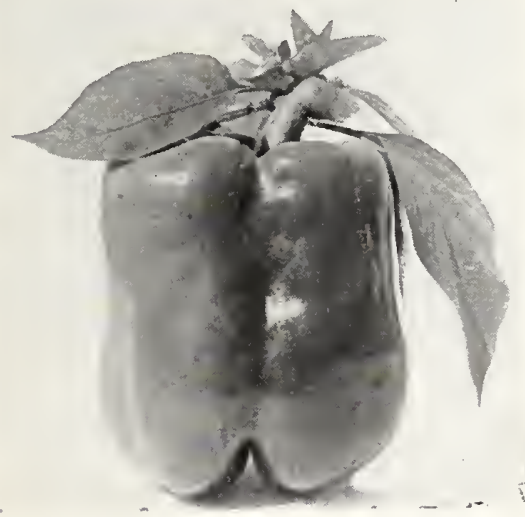

340-California Wonder

359-KENTUCKY F1ELD. Skin is deep orange, flesh somewhat lighter. One of the best. Pkt., 5c; oz., 10c; 1/1 lb., 25c; lb., 75c; 5 lbs., $\$ 3.00$, postpaid. Not prepaid, $10 \mathrm{lbs}$. or over at $50 \mathrm{c}$ per lb.

358-LARGE CHEESE. Flat and round like cheese Skin orange color Pkt, $5 \mathrm{c}$; oz. $10 \mathrm{c} ; 1 / 4$ lb., $25 \mathrm{c}$; lb., $85 \mathrm{c}$; 5 lbs., $\$ 3.75$, postpaid. Not prepaid, $10 \mathrm{lbs}$, or over at $60 \mathrm{c}$ per lb.

360-CONNECTICUT FIELD. Much used all over America for field culture. Pkt., 5c; oz., 10c; 1/4 lb., 30c; lb., 85c; 5 lbs., $\$ 3.75$, postpaid. Not prepaid, $10 \mathrm{lbs}$, or over at $60 \mathrm{c}$ per lb.

357-NICHOLSON'S BIG TOM. This is one of the largest of the round field varieties thick flesh which makes it desirable for stock feed; also fine for pies and drying for table use. Pkt., 5c: oz., 10c; $1 / 4$ lb., 30c; lb. $\$ 1.00 ; 5$ lbs., $\$ 4.50$, postpaid. Not prepaid, 10 lbs. or over at $75 \mathrm{c}$ per $1 \mathrm{~b}$. per lb. 10 lbs. or over at $90 \mathrm{c}$ per lb. 1/4 lb., 30c; lb., $\$ 1.00$, postpaid.

Plant a complete garden -make it worthwhile.

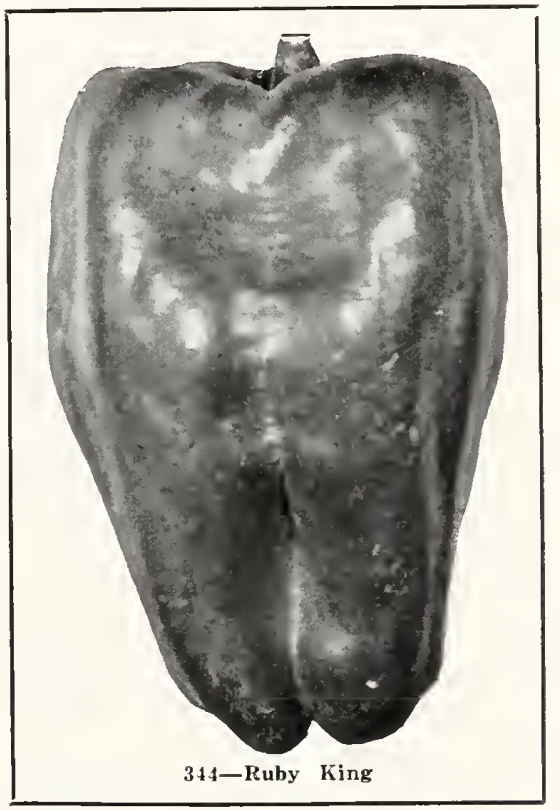

343-WORLD BEATER. This is a cross between Chinese Giant and Ruby King. A good size Pepper, mild flavored with thick flesh. One of the best varieties for both market gardening and home use; very prolific. Pkt., 10c; oz., 40c; 1/4 lb., \$1.10; lb., $\$ 4.00: 5$ lbs. $\$ 18.50$, postpaid. Not prepaid, 10 lbs. or over at $\$ 3.50$ per lb.

344-RUBY KING. Very prolific; when ripe the pods are a beautiful bright red, 3 to $4 \frac{1}{2}$ inches long and $2 \frac{1}{2}$ to $31 / 2$ inches in diameter; unsurpassed for slicing, stuffing or mangoes. Pkt., 10c; oz., 30c; $1 / 4$ lb., 90c: lb., $\$ 3.25$; 5 lbs., $\$ 15.00$, postpaid. Not prepaid, 10 lbs. or over at $\$ 2.75$ per lb.

345-BELL OR BULL NOSE. A large early, bright red variety, mild in flavor; desirable for pickling and mangoes. Pkt., $10 \mathrm{c}$ oz. 35c; 1/4 lb., \$1.00; lb., \$3.50; 5 lbs. $\$ 15.00$, post paid. Not prepaid, 10 lbs, or over at $\$ 2.85$ per $1 b$

349-ANAHEIM CHILI. A long type Pepper that is classed as a sweet pepper. In other words, its name is somewhat misleading. It has just sufficient suggestion of pungency to make it delicious. The fruits are meaty, measuring 5 to 7 inches in length, with a diameter of 1 inch or slightly more. It is highly valued as a green chili. While ripe and red, it is delicious served as a salad. Pkt., 10c; oz., 40c: 1/4 lb., \$1.40; lb. $\$ 5.00 ; 5$ lbs., $\$ 24.00$, postpaid.

346-TABAsCO. Tall, bush-like growth, produces great numbers of small, slender, very hot and fiery fruits, one inch long and bright scarlet. Fine for Pepper and Tabasco sauce. Pkt.. 10c; 0z., 45c: 1/4 lb., \$1.25; lb., $\$ 4.50$, postpaid.

347-LONG RED CAYENNE. A small, long, bright red variety, very productive, extremely strong and pungent; fine for pepper sauce and seasoning. Pkt., 10c; oz., 35c; 1/4 lb., $\$ 1.25$; lb., $\$ 4.00 ; 5$ lbs., $\$ 18.50$, postpaid.

348-MEXICAN CHILI. This is the Pepper used in making Mexican tamales and pungent sauces; a very distinct flavor. We have a good strain of this variety. Pkt., $10 \mathrm{c}$; $0 \mathrm{z}$. 35c; $1 / 4$ lb., $\$ 1.10$; lb., $\$ 4.00$, postpaid.

\section{Nicholson's Pumpkins \\ (CALABAZA TOTANERA)}

Pumpkins are not so particular as to soil as melons or cucumbers, but in other respects are cultivated the same, though on a large scale. They are generally ralsed between hills of corn, but may be planted with success in fields by themselves. The Pumpkin more properly belongs to the farm than the garden, especially as it really mixes with and injures the finer squash. Pumpkins are splendid feed for sheep when pasture begins to fail in the fall. One ounce of seed will plant 20 hills; three pounds will plant one acre.

356-GREEN STRIPED CUSHAW. This is the best and most popular Cushaw type cf Pumpkin for the South; is very attractive in appearance, with mottled green and white stripes; the flesh is a rich creamy yellow, fine grained, and excellent for pies or for breaking up and baking in the oven. Fine for planting in the cornfields, make abundant yields, and are good keepers. Pkt., 10c; oz., $15 \mathrm{c}$ : $1 / 4 \mathrm{lb}$., $40 \mathrm{c}$ : lb., $\$ 1.25$; 5 lbs., \$5.50, postpaid. Not prepaid, 10 lbs, or over at $90 \mathrm{c}$

355-JAPANESE PIE, Similar in size and form to the well known Cushaw, but the skin is a deep green, with dark stripes, turning to a rich yellow. Fruits mature early; the large neck is solidly meaty, Rich, deep yellow flesh. Pkt., 5c; oz., 15c; 1/4 lb., 40c; lb., $\$ 1.25 ; 5$ lbs., $\$ 5.50$, postpaid. Not prepaid,

361-SMALL SUGAR. Fruits of small size, averaging about 10 inches in diameter. of excellent keeping qualities; flattened or slightly ribbed. Skin deep orange-yellow; most excellent for pies. Pkt., I0c; oz., 15c

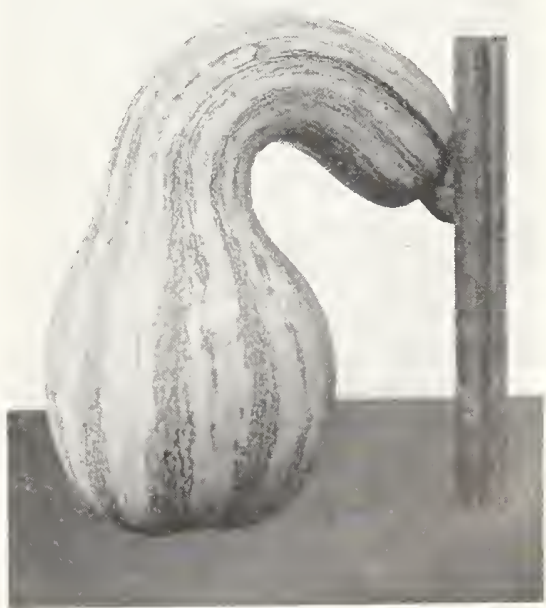

356-Green Striped Cushaw 
Nicholson's Selected Radish Seed

(RABANOS)

To have tender and crisp Radishes, they must be grown very quickly and in order to do this they should be planted in very rich soil and have plenty of water, commencing early in the spring and sowing at intervals of about a week or ten days. By doing this you will have nice fresh Radishes all the time. For fall and winter use you should start sowing seed in August and September, using the same methods as for spring planting. One ounce of seed will sow about 40 feet of drill, and about 5 or 6 pounds an acre.

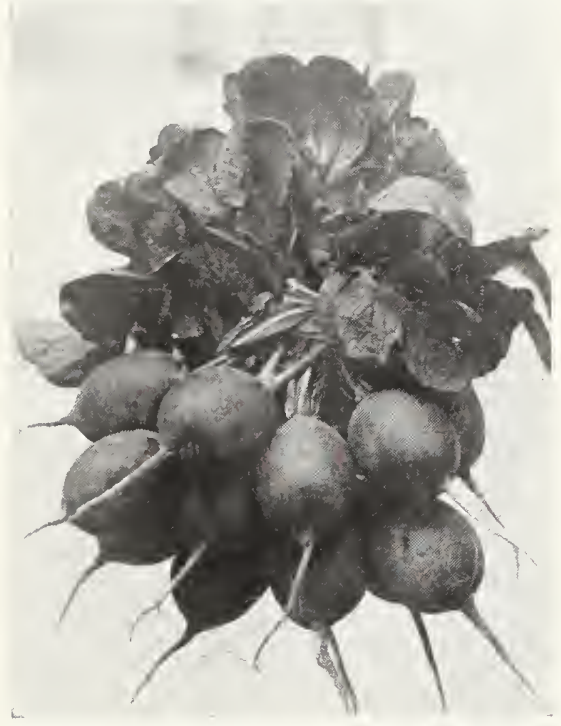

375-Vick's Scarlet Globe

380-FRENCH BREAKFAST. Half-long or olive shaped; for market and home garden: beautiful scarlet, shading to white at tip Pkt., 5c; 0z., 10c; $1 / 4$ lb., 25c; lb., 85c; 5 lbs., $\$ 3.50$, postpaid. Not prepaid, 10 lbs. or over at $60 \mathrm{c}$ per lb.

377-CHINA ROSE WINTER. Distinct handsome variety of winter Radish. Skin deep rose; flesh pure white, solid, of fine flavor. Keeps well. Roots long, of large cize and handsome appearance. Ready for use in 40 days. Pkt., 5c; oz., 10c; 1/4 lb. 25c: lb., $85 \mathrm{c}$; 5 lbs., $\$ 3.50$, postpaid. Not prepaid, 10 lbs. or over at $60 \mathrm{c}$ per lb.
376-NICHOLSON'S SPARKLER EARLY some, early, round sort: bricht searlet at top, shading to white at bottom: medium size, crisp and tender; fine for first early planting: not unusual to have Radishes in 18 days from time of planting. Pkt., 5c; oz., 10 c; $1 / 4$ lb., 25c; lb., 85c; 5 lbs., \$3.50, postpaid. Not prepaid, 10 lbs, or over at $60 \mathrm{c}$ per $\mathbf{l b .}$

384-EARLY DEEP SCARLET TURNIP. This is an excellent extra early quick-growing Radish. The roots are small, round or turnip-shaped, and always a beautiful bright scarlet color. Pkt., 5c; oz., 10c; 1/4 lb., 25c: lb., 85c: 5 lbs., $\$ 3.50$, postpaid. Not prepaid, 10 lbs. or over at $60 \mathrm{c}$ per lb.

385-CRIMSON GIANT. This variety is similar to "Deep Scarlet Turnip", but grows to larger size. The roots are a beautiful crimson color, and of most excellent quality. It is the best variety to grow for the market, and is equally desirable for the home garden. Pkt., 5c; oz., 10c; 1/4 lb., 25c; lb., 85c; 5 lbs., $\$ 3.50$, postpaid. Not prepaid, 10 lbs. or over at $50 \mathrm{c}$ per lb.

379-LONG WHITE VIENNA. Early maturing; long, white; of excellent quality. Ready for use in 30 days from planting. Pkt., 5c; oz., 10c; 1/4 lb., 25c; lb., 85c; 5 lbs., $\$ 3.50$, postpaid. Not prepaid, 10 lbs. or over at $60 \mathrm{c}$ per $1 \mathrm{~b}$.

381-CHARTIER. For main crop and summer sowing; stands heat well. Scarlet at top, shading to clear waxy white at tip. Remains crisp and tender for a long time. Pkt., 5c: oz., 10c; 1/4 lb., 25c; lb., 85c; 5 lbs., \$3.50, postpaid. Not prepaid, 10 lbs. or over at $60 \mathrm{c}$. per $\mathbf{l b}$.

383-LONG SCARLET SHORT TOP. Tops rather small; roots long and tapering; an intense bright scarlet; very crisp and tender. Ready for use in 25 to 28 days. Pkt., $5 \mathrm{c}$; oz., 10c; $1 / 4$ lb., 25c; lb., 85c; 5 lbs., $\$ 3.50$, postpaid. Not prepaid, 10 lbs. or over at 60c per $\mathbf{l b}$. SCARLET TURNIP WHITE TIPPED. Hand-

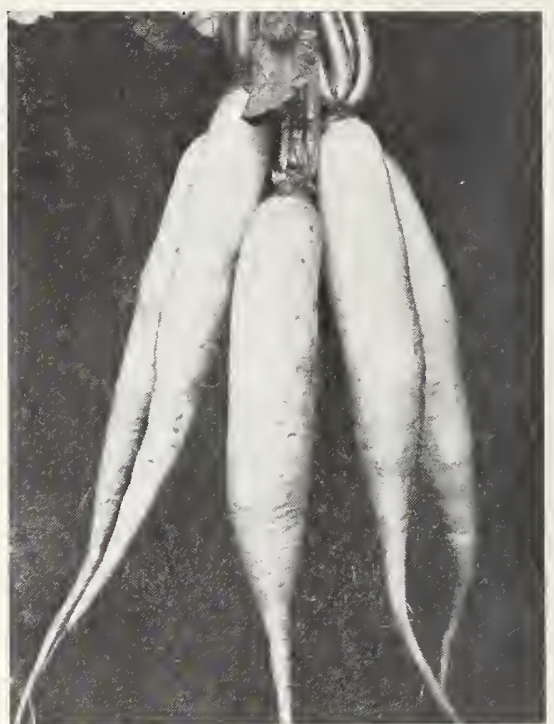

382-Icicle

382-ICICLE. Radishes measuring from 4 to 5 inches long and one-half to three-fourths inch thick. Earlier than any other long white Radish; pure white, almost transparent; very tender. Pkt., 5c; oz., 10c; 1/4 lb.. 25c; lb., $85 \mathrm{c}$; 5 lbs., $\$ 3.50$, postpaid. Not prepaid, 10 lbs. or over at $60 \mathrm{c}$ per lb.

378-CINCINNATI MARKET ("Glass" Radish). A strain of the Long Scarlet: grows slightly larger, fully as early; darker in coloring. Popular in the South and largely planted for shipping North in early spring. Pkt., 5c; oz., 10c; 1/4 lb., 25c; lb., 85c; 5 lbs., \$3.50, postpaid. Not prepaid, $10 \mathrm{lbs}$, os over at $60 \mathrm{c}$ per $l b$.

375-VICK'S EARLY SCARLET GLOBE. The roots have an attractive bright scarlet color, are slightly olive-shaped, and always crisp and tender. This is one of the best sorts to grow for the market, and is becoming more popular each year. Pkt., 5c; oz., 10c; $1 / 4$ lb., 25c; lb., 85c; 5 lbs., \$3.50, postpaid. Not prepaid, 10 lbs. or over at $60 \mathrm{c}$ per lb.

\section{Nicholson's Squash}

\section{(CALABACINES)}

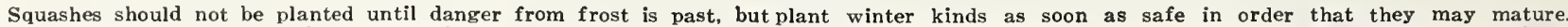

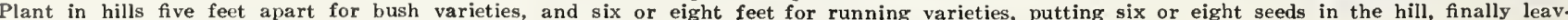
ing hut three plants. One ounce plants 25 hills; four to five pounds plant an acre.

367-HUBBARD. Well known winter Squash. Vines of strong running growth; fruits large, olive shape, with dark green skin and very rich flesh. Pkt., 5c; oz., 15c; $1 / 4$ lb., 40c; lb., \$1.25; 5 lbs., \$5.00, postpaid. Not prepaid, 10 lbs, or over at 75 c per $1 \mathrm{~b}$.

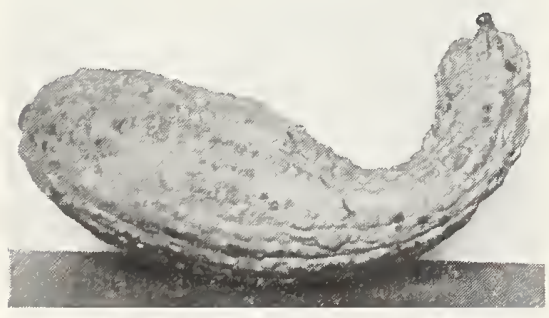

366-Yellow Summer Crookneck
365-EARLY WHITE BUSH. Standard summer variety; good for home and market. Pkt., 5c; oz., 15c; 1/4 lb., 35c; lb., \$1.00; 5 lbs., $\$ 4.00$, postpaid. Not prepaid, $10 \mathrm{lbs}$. or over at $70 \mathrm{c}$ per $1 \mathrm{~b}$.

366-YELLOW SUMMER CROOKNECK. Large, standard summer variety, small crookneck. Early, productive. Pkt., 5c; oz., 15c; 3/4 lb., 40c; lb., \$1.25; 5 lbs., \$5.00, postpaid. Not prepaid, 10 lbs. or over at $75 \mathrm{c}$ per lb.

369-FORDHOOK. A summer variety adapted also for winter use. The fruits are 8 to 10 inches long by about 8 inches thick, and have a light cream colored skin. The flesh is a rich creamy yellow thick and sweet. May be baked in the oven like a sweet potato and served with melted butter, and when prepared in this way the finest pumpkins and cushaws are not to be compared with it. The fruits may be stored in a cool, dry cellar for winter use, and will keep several months. Pkt., 5c; oz., 15c; 1/4 lb., 40c; lb., \$1.25; 5 lbs., $\$ 5.00$, postpaid. Not prepaid, $10 \mathrm{lbs}$, or over, $75 \mathrm{c}$ per lb.

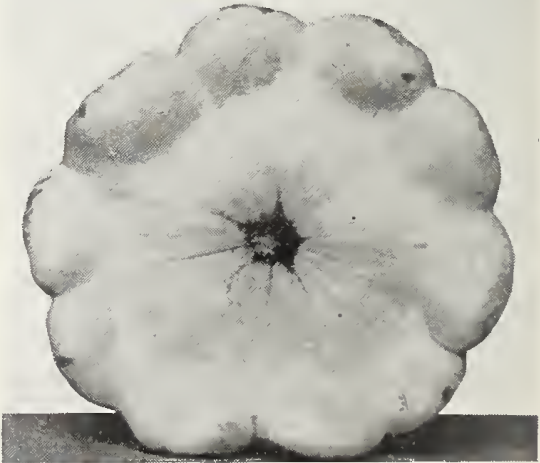

365-Early White Bush 


\section{Re-Selected Spinach Seed \\ (ESPINACA)}

We have our Spinach seed grown in Holland under contract and sell about 100,000 lbs. per year. Should be planted in very rich ground, the richer the better. Can be planted in our climate either in the fall or early spring. It requires about 20 pounds to sow an acre broadcast; 5 to 8 pounds per acre in drills; one ounce to 30 or 35 feet of drill.

391-NEW ZEALAND (Summer Spinach). An excellent summer growing variety that will stand the hottest weather. You can cut it and it will come again. A few plants will furnish greens of wonderful flavor, all summer, for an average family. A variety that is particularly adapted to the South. It does well on poor or rich soil. We suggest that you soak the seed for 12 to 24 hours to hasten germination. Pkt., 10c; 0z, 15c: $1 / 1$ lb., 30c; lb., $\$ 1.00 ; 5$ lbs., $\$ 4.00$, postpaid

389-BLOOMSDALE RE-SELECTED SA VOY-LEAVED. Leaves are curled and crinkled like the Savoy Cabbage; hardy and most productive. Pkt., 5c: oz, 10c: 1/4 lb., 20c: lb., 50c; 5 lbs., $\$ 2.00$, postpaid. Not prepaid. 10 lbs., $\$ 2.50 ; 50$ lbs., $\$ 8.25 ; 100$ lbs., $\$ 16.00$ Write fer prices on larger quantities.
392-NOBEL GIANT THICK LEAF. This is a quick-growing variety, and produces large, almost round leaves, dark green in color, and of excellent quality. Will stand a long time before going to seed, and makes a larger yield per acre than most other va rieties. A very desirable variety for market gardeners, and, because the leaves are smooth and easy to wash, it is very extensively grown for canning. Pkt., 5c; oz., 10c; 1/4 lb. $20 \mathrm{c}$; lb. $50 \mathrm{c} ; 5$ lbs., $\$ 2.00$, postpaid. Not prepaid, 10 lbs., $\$ 2.50 ; 50$ lbs., $\$ 8.25 ; 100$ lbs., $\$ 16.00$.

390-IMPROVED TIIICK-LEAVED VIROFLAY. Very large, thick, dark green leaves: favorite market gardeners' sort for fall or spring. Pkt., 5c; oz., 10c; $1 / 4$ lb., 20c; lb. $50 c$ : 5 lbs., \$2.00, postpaid. Not prepaid, 10 lbs., $\$ 2.50 ; 50$ lbs., $\$ 8.25 ; 100$ lbs., $\$ 16.00$.

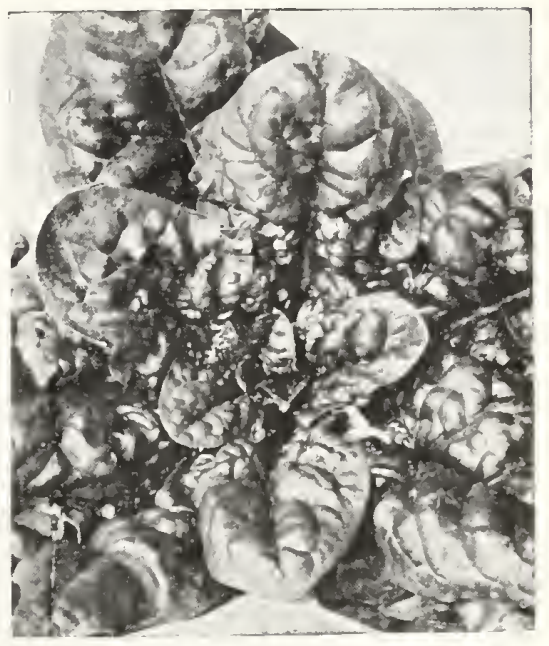

389-Bloomsdale Spinach

\section{Nicholson's Selected Tomato Seed}

\section{7-Nicholson's New Break o' Day}

This was originated by the late Dr. Fred J. Pritchard, Senior Physiologist of the United States Department of Agriculture. From Florida to New Jersey, or wherever tried last year, it created a sensation, yielding in some instances as mucb as 15 tons to the acre. The fruits are large, smooth, red, heavily meated and globular in shape. It is as early as Earliana, 10 to 12 days earlier than Marglobe, and a heavier yielder than either. Nicholson's New Break o' Day is an excellent shipper. All tests have proven that the fruits very seldom crack and are not effected by sun scald; vines are practically free from blossom-end rot, even when planted with other sorts that would be affected as much as 90 per cent. The open spreading vine with small leaves is wilt resistant and sets fruits freely. This wonderful new Tomato should prove invaluable to Texas. Pkt., 15c: oz., 60c; $1 / 4$ lb., $\$ 2.25$; $1 / 2$ lb., $\$ 4.00 ; 1 b ., \$ 7.50$, postpaid.

413-MARGLOBE. Cross between Livingston's Globe Tomato and a French variety by the name of Marvel. It is a bright red variety not only on the surface but all the way through. It is about the same size and shape as Livingston's Globe. One of the best features is its resistance to wilt and nail head rust. An excellent shipping and market variety. Has very small core. Pkt., 10c; oz., 50c; $1 / 4$ lb., $\$ 1.50$; lb., $\$ 5.00$; 5 lbs., $\$ 22.50$, postpaid. Not prepaid, 10 lbs. or over ut $\$ 4.00$ per lb.

412-GULF STATES MARKET. A very desirable sort for the home gardener or the grower for local markets. The vines are exceptionally robust. The fruits are almost true globe-shaped and are entirely free from cracks or blemishes about the blossom end. Fruits on the same cluster ripen uniformly, making it an economical variety to pick. The fruit colors a rich purplish pink clear to the stem after picking. Pkt., 10c; oz., 45c; 1/4 lb., \$1.35; lb., \$4.50; 5 lbs., \$20.00, postpaid. Not prepaid, $10 \mathrm{lbs}$. or over at $\$ 3.50$ per $\mathbf{l b}$.

408-McGEE. Originated in Texas. Bright crimson, solid and of good flavor. Yields splendid crops where other sorts fail. Especially recommended for black land. Pkt. 10c: oz. 35c; $1 / 4$ lb. $\$ 1.00 ;$ lb., $\$ 3.50 ; 5$ lbs., $\$ 16.00$, postpaid. Not prepaid, 10 lbs, or over at $\$ 3.00$ per lb.

\section{8-Nicholson's New Pritchard}

\section{(Previously known as "Scarlet Topper")}

The late Dr. F. J. Pritchard of the United States Department of Agriculture has introduced several tomatoes with real merit-and this glorious new variety is claimed by many to be the prize-winner of them all. It is a cross between Marglobe and Cooper's Special.

Dr. Pritchard had this to say about New Pritchard: "New early tomato. Fruits large, smooth, meaty, very red, globular. Vines medium, dense, erect, self topping-prodigious cropper." This is indeed a concise description-but at the same time is about all that could be said of a tomato nearing perfection.

Especially bred up for a green wrapped tomato, also an excellent canner and it ripens well up to the stem end. It has a tendency to set a rather large number of fruits. It therefore requires either a naturally fertile soil or one well fertilized in order to size up the fruit properly and produce the maximum quantity of fruit per vine. We do not hesitate to recommend this new tomato to our most critical customers for trial. Price: pkt. 25c: oz., $\$ 1.25 ; 1 / 4$ lb., $\$ 4.00$; $1 / 2$ lb., $\$ 8.00$; lb., $\$ 15.00$, postpaid.

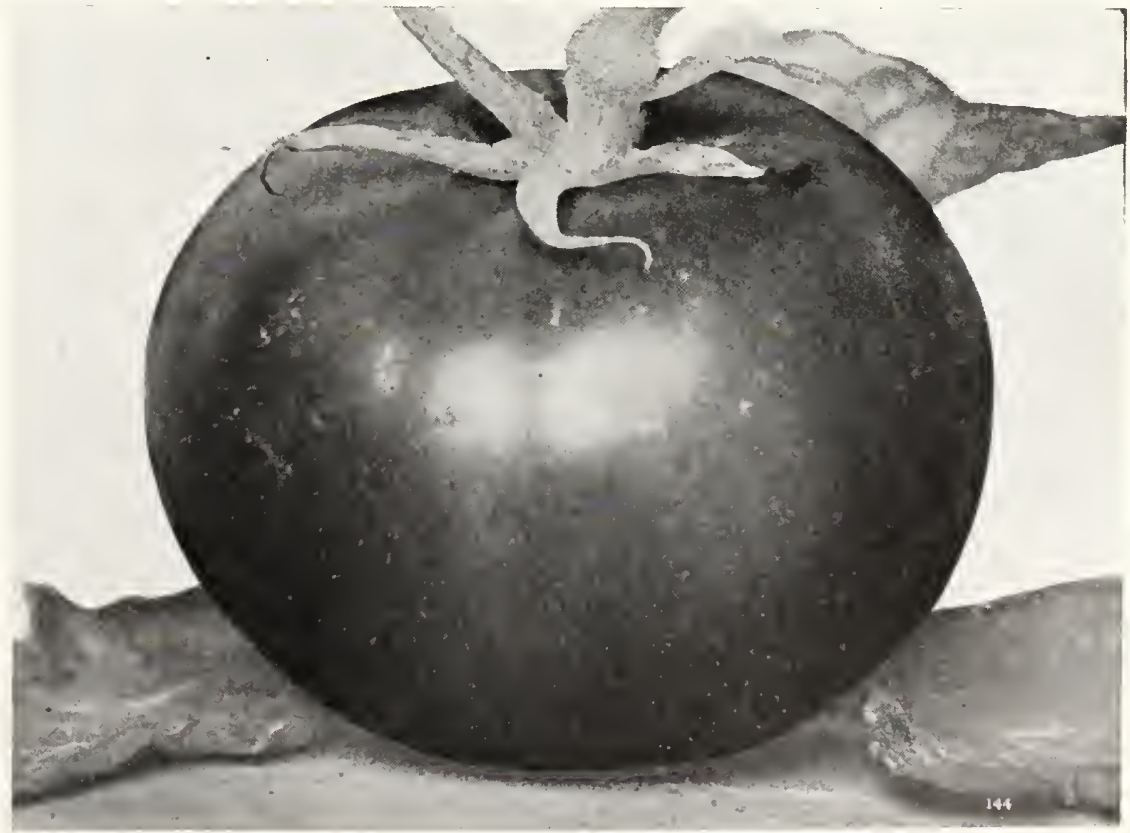

398-Nicholson's New Pritchard 


\section{Robert Nicholson}

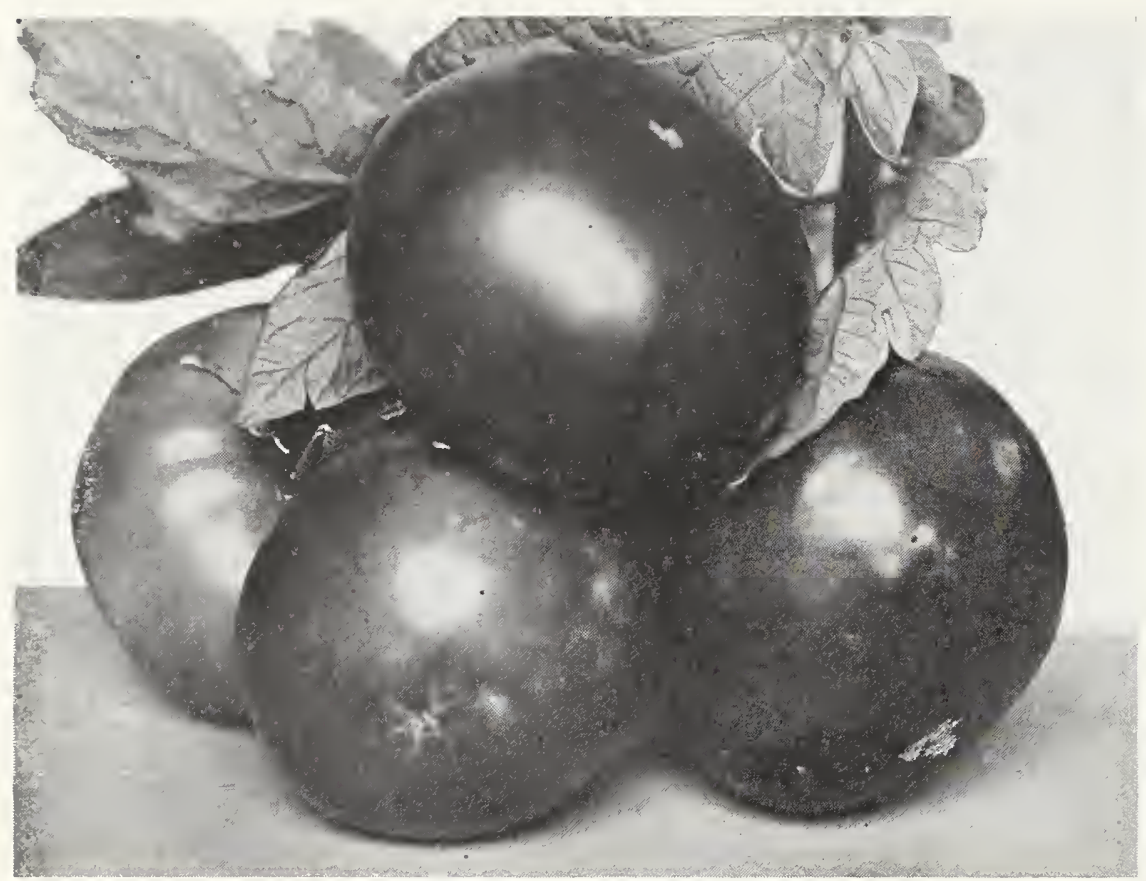

395-Nicholson's Prolific Tomato

400-EARLY DETROIT. Vigorous and very productive, smooth and uniform in size, nearly globe shape, firm, excellent quality. One of the most valuable shipping Tomatoes yet produced. Pkt., 10c; oz., 35c; $1 / 4$ lb., $\$ 1.00$; lb., $\$ 3.75$; 5 lbs.. $\$ 17.50$, postpaid. Not prepaid, 10 lbs. or over at $\$ 3.25$ per 1 b.

405-GREATER BALTIMORE. In appear ance it is similar to the Stone and is enormously productive, and is especially fine for canning; has large, solid fruits of a brilliant red color. Pkt., 10c; oz., 25c; 1/4 lb., 75c; lb., $\$ 2.75 ; 5$ lbs., $\$ 12.50$, postpaid. Not pre paid, 10 ibs. or over at $\$ 2.25$ per lb.

399-LIVINGSTON'S GLOBE. A large, purplish pink, globe-shaped or very nearly round Tomato. It is extensively used for shipping. The vines are very vigorous and productive. The fruits are rather uneven in size but are very smooth and mature a little earlier than most midseason or main crop varieties. Pkt., 10c; oz., 45c; 1/4 lb., $\$ 1.35$; lb., $\$ 4.50$; 5 lbs., $\$ 18.50$, postpaid. Not prepaid, 10 lbs. or over at $\$ 3.50$ per lb.

409-SPARKS' EARLIANA. Medium size, of superb pink color, very prolific, fruits forming almost in clusters. Very handsome in shape, quite solid, and of fine quality. Very popular for early market. Pkt., 10c; oz., 35c $1 / 4$ lb., $\$ 1.00$; lb., $\$ 3.50 ; 5$ lbs., $\$ 15.00$, postpaid. Not prepaid, 10 lbs. or over at $\$ 2.50$ per lb.

414-CHALK'S EARLY JEWEL. This is one of the best and most popular varieties. Vines are very vigorous and productive, and fruits are a deep scarlet-red, slightly flattened, smooth, and of large size. Continues to bear fruit through a long season. Pkt., $10 \mathrm{c} ; 0 \mathrm{z} ., 25 \mathrm{c} ; 1 / \mathrm{l}$ lb., $85 \mathrm{c}$; lb., $\$ 2.85 ; 5 \mathrm{lbs}$, $\$ 12.50$, postpaid. Not prepaid, 10 lbs. or over at $\$ 2.25$ per $1 b$.

406-THE STONE. This variety has at tained immense popularity with market gardeners, Southern growers, canners and home growers everywhere. Its solidity and carrying qualities are remarkable. Its color is a desirable red, its shape is excellent; perfectly smooth. Pkt., 10c; oz., 25c; 1/4 lb., 75c; lb. $\$ 2.75 ; 5$ lbs., $\$ 12.00$, postpaid. Not prepaid. 10 lbs. or over at $\$ 2.25$ per lb.
416-CLARK'S EARLY. The fruits are large, semi-globe and regular in shape. Medium early and handsome deep scarlet in color. Smooth and exceptionally deep through from stem to bloom end. Is a good slicer, heavily meated, with small seed pockets and very small core. This variety is used extensively in the Rio Grande Valley of Texas. The vines are vigorous, prolific and bear their fruit in clusters. Pkt., 10c; oz., 45c; $1 / 4$ lb., \$1.35; lb., \$4.50; 5 lbs,, \$20.00, postpaid. Not prepaid, 10 lbs, or over at $\$ 3.50$ per 1 b.

404-EARLY ACME. One of the best known old standard varieties; bright red, the fruits are round and very solid, and of uniform shape. We recommend this variety for home use. Pkt., 10c; oz., 35c; 1/1 lb., \$1.00: paid, 10 ibs. or over at $\$ 3.00$ per $1 b$.

418-BONNY BEST. Fruits of beautiful shape and color: a good variety for early market and home use. Scarlet fruit with vigorous vine. Crop ripens uniformly. Pkt., $\$ 16.00$, postpaid. Not prepaid, 10 lbs, or over, $\$ 3.00$ per lb.

403-DWARF STONE. Claimed to be the largest dwarf Tomato known, almost double the size of Dwarf Champion, and is similar in habit of growth; very popular with market gardeners and home canners. Pkt., 10c; oz., 45 ; $1 / 1$ lb., $\$ 1.35$; lb., $\$ 4.50 ; 5$ lbs., $\$ 20.00$, postpaid. Not prepaid, $10 \mathrm{lbs}$. or over at $\$ 3.75$ per lb.

402-DWARF CHAMPION. Distinct in foliage and habit of growth, being compact and upright. Fruits smooth, early, and of beautiful purplish red color. Pkt., 10c; oz., 45c; $1 / 1$ lb., \$1.35; lb., \$4.50; 5 lbs., \$20.00, postpaid. Not prepaid, 10 lbs. or over at $\$ 3.75$ per 1 .

401-YELLOW PEAR. Largely used while green for pickles and preserves; also for preserving after ripe; this is a very prolific variety and does well in any of the Tomato growing States. Pkt., 10c; oz., 40c; 1/4 lb. $\$ 1.50$; lbs., $\$ 5.00$, postpaid. lb., $\$ 3.50$; 5 lbs., $\$ 16.00$, postpaid. Not pre10c: oz., 40c; $1 / 4$ lb., $\$ 1.25$; lb., $\$ 4.00$; 5 lbs.,

\section{5-Nicholson's Prolific Tomato}

This variety comes along in the summer after most other Tomatoes are gone. It ripens about twenty days later than such varieties as Earliana. We recommend this to be the best late Tomato. Some fruits weigh one pound and over. Is perfectly filled out and does not contain any hollows like so many varieties. The surface is as smooth as an apple, the flesh is solid, a splendid shipper. It is a magnificent scarlet shade, which makes it very attractive. Very sweet and free from acid taste. The yield is enormous. This Tomato has proven to be absolutely blight resisting and endures drought well. The growth is strong and healthy, plants having a diameter of from 6 to 8 feet. Pkt., $15 \mathrm{c} ;$ oz., 60c; $1 / 4$ lb., $\$ 2.00$; lb., $\$ 7.50$, postpaid.

397-JUNE PINK TOMATO. Purplish pink Tomato similar to the popular Earliana in growth of vine, shape and size of fruits. A valuable variety for market gardeners who want a very early, purplish pink Tomato. Pkt., 10c: oz, 45c; 1/ 1b., \$1.35; lb. \$4.50; 5 lbs., $\$ 20.00$, postpaid. Not prepaid, 10 lbs. or over at $\$ 3.50$ per $1 b$.

396-NICHOLSON'S IMPROVED BLACK LAND TOMATO. This Tomato is an improvement on the McGee. Very heavy yielder and desirable for planting in the black land of Texas. Has a good constitution. Fruit all runs a true pink color. The vine is shortjointed. We recommend this variety very highly. Pkt., 10c; oz., 40c; 1/4 lb., \$1.35; lb., $\$ 4.50$; 5 lbs., $\$ 20.00$, postpaid. Not prepaid, 10 lbs. or over at $\$ 3.50$ per $l b$.

407-PONDEROSA. Very large, solid and of good flavor; specimens have been grown to weigh four pounds. Pkt., 10c; oz., 50c ; 1/4 lb., $\$ 1.75 ;$ lb., $\$ 6.00$, postpaid.

411-NICHOLSON'S REDFIELD BEAUTY Fine selected strain of Beauty Tomato. Large, smooth, flesh of finest quality. Glossy crimson, purplish shading. Pkt., 10c; oz., 40c; $1 / 4$ lb., $\$ 1.25$; lb., $\$ 4.00$; 5 lbs., $\$ 16.00$, postpaid. Not prepaid, 10 lbs. or over at $\$ 3.00$ per lb.

415-JOHN BAER. This is a hardy and very prolific extra early variety. The fruits are of large size, scarlet in color, nearly round, smooth, firm and of excellent quality. One of the first varieties to ripen, and continues to bear a long time. A very desirable sort for gardeners, shippers and canners, and equally desirable to grow for home use. Pkt. $10 \mathrm{c} ;$ oz., 25c; $1 / 4$ lb., 85c; lb., $\$ 2.85$; 5 lbs., $\$ 12.50$, postpaid. Not prepaid, 10 lbs, or over at $\$ 2.25$ per $\mathbf{l b}$.

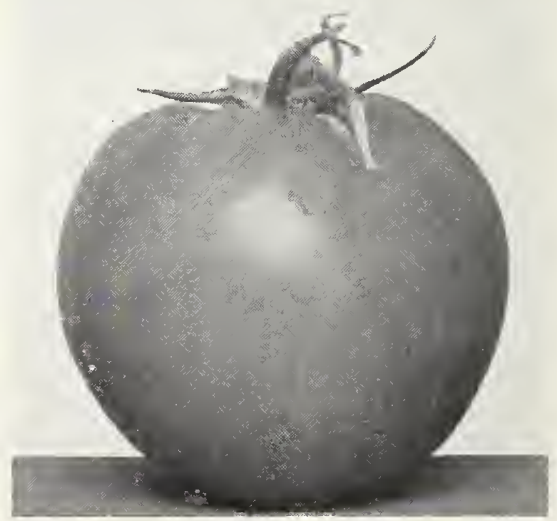

402-Dwarf Champion Tomato 


\section{Tested Seeds for}

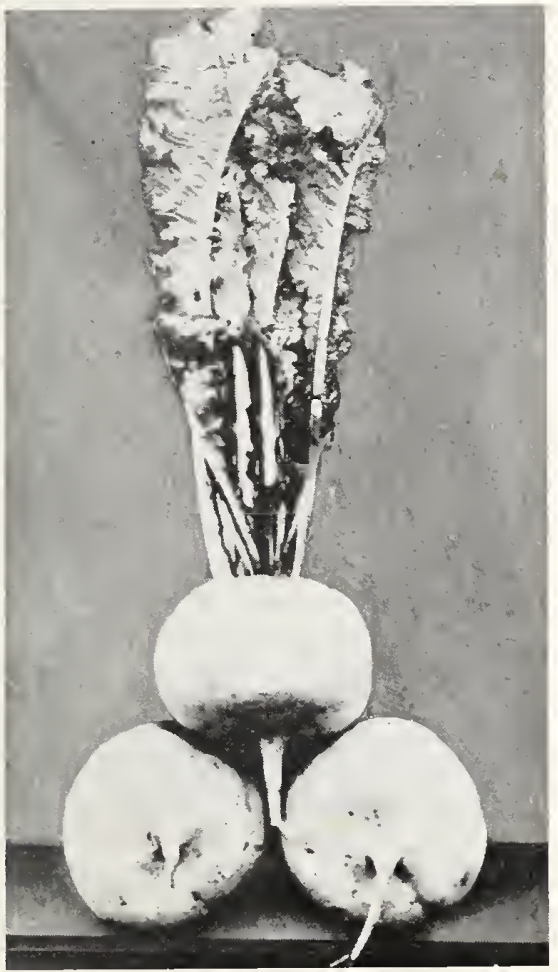

432-Shogoin

432-SHOGOIN. A splendid Turnip of Oriental origin that has proved its worth in many ways. It is very resistant to both insect pests and blight, and will grow in hot and dry weather better than any other variety. The roots are pure white and globe shaped, usually blunt or flattened at the bottom. The tops are of upright growth, and are said by many to be superior to those of any other Turnip for greens. Pkt., 5c; oz. 15 c; 1/4 lb., 25c; lb., 75c; 5 lbs., \$3.00, postpaid.

427-AMBER GLOBE. One of the most desirable of the yellow varieties for main fall crop Turnip. Pkt., 5c; oz., 10c; $1 / 4$ lb., 20c ; lb., 55c; 5 lbs., $\$ 2.00$, postpaid.

\section{Turnips \\ (NABOS)}

420-EARLY SNOWBALL. Nearly round, medium size, of fine appearance, with a smooth white skin, maturing very early, being ready in 6 to 8 weeks. Pkt., 5c; oz., 10c: $1 / 4$ lb., 20c; lb., 55c; 5 lbs., $\$ 2.00$, postpaid. 421-EARLY PURPLE TOP STRAP LEAF. Flat; white with purple top, fine grained and exceedingly tender; it is claimed by all gardeners to be the best for early spring or fall sowing because of the extreme earliness. Pkt., 5c; oz., 10c; 1/4 lb., 20c; lb., 55c; 5 lbs., $\$ 2.00$, post paid.

422-WHITE FLAT DUTCH. Practically the same as the Early Purple Top Strap Leaf, except in color. It is snowy white, very tender and crisp. Pkt., 5c; oz., 10c; 1/4 lb., 20c: lb., 55c: 5 lbs., $\$ 2.00$, postpaid.

423-PURPLE TOP WHITE GLOBE. This excellent table variety is globular in shape, of good size and very attractive appearance. The roots are large, purple or dark red above the ground and snowy white below. Pkt., 5c oz., 10c; $1 / 4$ lb., 20c; lb., 55c; 5 lbs., $\$ 2.00$, postpaid.

424-EXTRA EARLY PURPLE TOP MILAN. The earliest Turnip grown, being ready two weeks sooner than any other. Of medium size with very much flattened round roots, smooth and white with a purple-red top. Leaves short and few. Flesh white and of splendid quality. Pkt., 5c; oz., 10c; 1/4 lb. $25 \mathrm{c}$; lb., 75c; 5 lbs., $\$ 3.00$, postpaid.

425-WHITE EGG. This is a snowy white, egg-shaped, and very rapid growing Turnip, very popular for early fall market. Pkt., 5c oz., 10c; 1/4 lb., 20c; lb., 55c; 5 lbs., \$2.00, postpaid.

426-GOLDEN BALL. Flesh of fine tex ture, making it one of the best table varieties. Pkt., 5c; oz., 10c; 1/4 lb., 20c; lb., 55c; 5 lbs. $\$ 2.00$, postpaid.

430-COW HORN. A great winter variety and is recommended for its great feeding value and enormous yields. It is also good as a table variety if used when young. Pkt. $5 c$; oz., 10c; 1/4 lb., 20c; lb., 55 c; 5 lbs., $\$ 2.00$ postpaid.

431-SEVEN TOP OR SOUTHERN PRIZE. The name describes this Turnip. It has a very heavy top; although it makes nice Turnips it is used more for greens in late fall and early spring, as it does not winter-kill. Pkt. $5 c ; 0 z ., 10 c ; 1 / 4$ lb., 20c; lb., 55c; 5 lbs., $\$ 2.00$ postpaid.

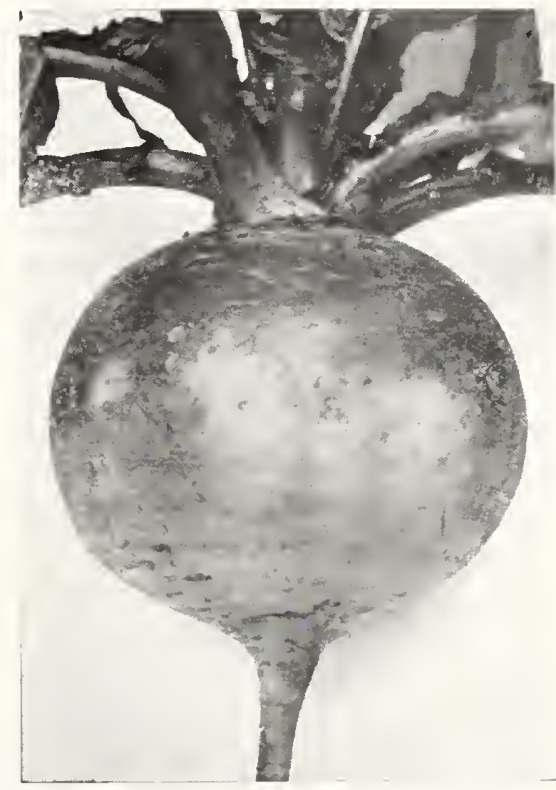

423-Purple Top White Globe

428-POMERANIAN WHITE GLOBE. This is a large globe-shaped and clear wbite Turnip and is recognized as a very valuable variety for market gardeners, also for home use, as the excellent large, crisp and tender tops are unexcelled for greens. Pkt., 5c; oz. $10 \mathrm{c}$; $1 / 4$ lb., 20c; lb., 55c; 5 lbs., $\$ 2.00$, post paid.

429-WINTER WHITE GLOBE. It is of medium size and is excellent for both greens and turnips. Pkt., 5c; oz., 10c; 1/4 lb., 20c lb., $55 \mathrm{c} ; 5$ lbs., $\$ 2.00$, postpaid.

\section{Rutabaga}

435-AMERICAN PURPLE TOP YELLOW This is a wonderful fall and winter variety. It is remarkable for its uniform shape, size and quality. Pkt., 5c; oz., 10c; 1/4 lb., 20c; lb., 55c; 5 lbs., $\$ 2.00$, postpaid.

PLEASE WRITE FOR PRICES IN LARGER LOTS.

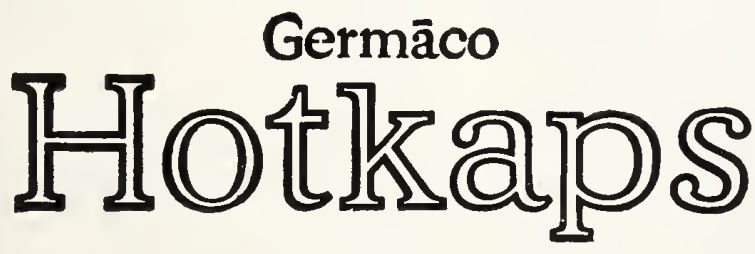

\section{Protect Plants From Frost}

For Earlier Crops and Higher Prices

Germaco HOTKAPS are patented wax paper cones that completely cover each plant-the only way to fully protect them from frost. They are an "individual bot-house for each plant", protecting them not only from frost, but from wind, rain, ground-crusting, and insects as well. This is your assurance of earlier, bigger crops and early to market prices.

HOTKAPS are quickly and easily "set". One man can set over 3,000 of them a day. The illustrations on the right show bow they are placed with the aid of the Germaco HOTKAP Setter and Tamper. Thousands of progressive farmers in every State are now regular users of this modern crop necessity. They are getting bigger, hardier crops and greater profits than ever before.

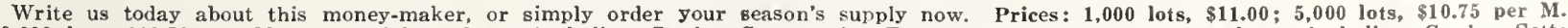

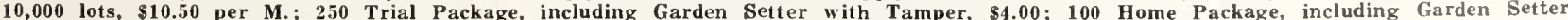

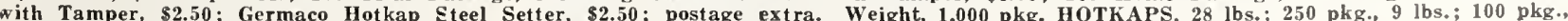
5 lbs.; Steel Hotkap Setter, 3 lbs. 


\section{Robert Nicholson}

\section{Herbs}

(Hierbas Aromaticas, Medicinales y para Condimento)

Your garden is not complete without a few Herbs. They are used extensively for flavoring soups, meats, etc. Sow seed in shallow drills, one foot apart, and thin out plants when well started.

438-ANISE. Used for garnishing and sea439-SWEET BASIL. For highly seasoned dishes.

440-CARAWAY. For flavoring.

441-CORIANDER. Seeds used in confectionery.

$442-$ DILL. Leaves used in pickles and fla-

443-SAGE. Leaves used for flavoring sauages.

444-THYME. For seasoning; tea is made from leaves for nervous headaches.

Price, any of above, pkt., 10c; 3 pkts., 25c, postpaid.

\section{Roots}

ASPARAGUS. See page 20.

RHUBARB. Large, strong roots, best cooking variety. $25 \mathrm{c}$ each; $\$ 2.50$ per doz. 100.

HORSERADISH. 40c per doz.; $\$ 2.50$ per

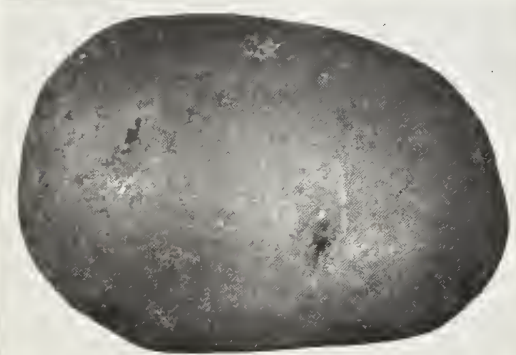

Irish Cobbler Potato

\section{Seed Irish Potato}

There is as much difference between certified and uncertified Potatoes as there is between pedigreed stock and scrub stock.

Certified Potatoes must pass through field inspection by the Department of Agriculture and must be true to variety, type and free from wart, powdery scab and late blight. It pays to plant Certified Seed Potatoes.

They should also be treated with Semesan Bel before planting.

CERTIFIED TRIUMPHS. Ask for prices.

CERTIFIED IRISH COBBLERS. Ask for prices.

TREAT YOUR POTATOES WITH SEMESAN BEL BEFORE PLANTING

The modern superior way of disinfecting seed Potatoes is with Semesan Bel, the instantaneous dip, easily used without expensive equipment. It does away with long-time soaking of the seed and effectively coats them with a disinfectant which commonly remains on the seed piece throughout the season. Write for Semesan Bel Potato Booklet.

\section{Seed Sweet Potatoes}

We can supply Certified Porto Rico Yams that have been especially seeded and grown for seed purposes. When planting cover above five inches deep and water moderately. When plants are formed set one foot apart on ridges four feet apart, well drawn up and rather flat. Cultivate well. Pk., 60c: bu. 1.75, f. o. b. Dallas.

\section{Raise Early Onions From Nicholson's Onion Plants}

For those who desire an early crop, either for table use or for local marketing, these plants will prove most desirable, and the fact that they are inexpensive and call for the minimum of labor and trouble in producing the crop has created an ever-increasing demand for them. They may be set out at the same time you would plant sets or cabbage plants. Plant in rows about 15 inches apart and 3 to 4 inches apart in row.

We can supply the following varieties:

YELLOW BERMUDA. A light straw colored Onion, which compares with the Bermuda in mildness of flavor and for this reason it is extensively planted, especially in the South, where it reaches perfection.

CRYSTAL WHITE WAX BERMUDA. Unquestionably the most attractive Onion in the world. It is an absolutely pure white, with a most beautiful waxy appearance that makes it sell on sight in all markets. No other Onion has such a clear white skin, such mildness of flavor. It is deliciously tender and can be eaten raw like an apple. $A$ large yielder.

Price, 25c per $100 ; \$ 1.10$ per $500 ; \$ 2.00$ per 1000 , postpaid. Not prepaid, $\$ 1.25$ per 1000 . Ask for prices on larger quantities.

\section{Nicholson's Frost-Proof Cabbage Plants}

Guarantee You Earlier and Larger Crops

Our Cabbage Plants are grown from the best seed and in a section where they have low temperature in early spring, which makes them hardy and frost proof and they will usually live at any temperature exceeding 20 degrees above zero; however, frost proof does not mean freeze proof.

You Gain Several Weeks

Our plants will produce full grown heads several weeks before the ordinary Cabbage plants. That is why it is more profitable to use Nicholson's plants, as the early vegetables are the ones that bring the money.

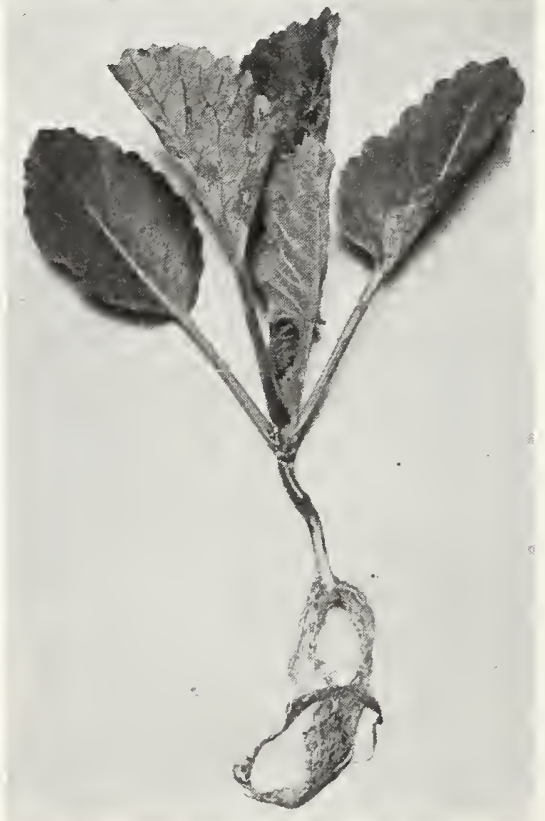

Cabbage Plants

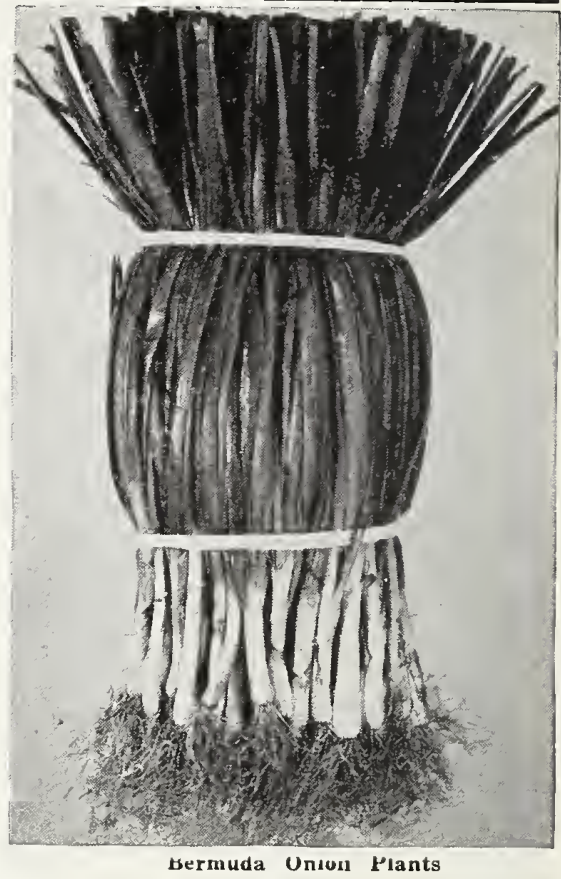

When the plants come to you they may look wilted and leaves have a brownish red look as though they were dead, but don't bother about the appearance, plant all of them just the same. Place them in the ground a month before you would set out home grown plants.

Orders for plants will be shipped in about four or five days after they are received if weather conditions permit. If plants do not arrive as soon as you expect them you may know that conditions beyond our control are causing the delay. If the plants cannot be set out the same day they are received, take them out of the package at once, dip the roots in water and heel out in the ground. From the first of November until the last of May, we offer the following well known varieties: Early Jersey Wakefild, Stein's Early Flat Dutch or Succession. Prices by parcel post: In lots of $100,200,300$ or 400 plants at 50c per 100 plants; 500 plants for $\$ 1.50$; 1000 or more at $\$ 2.50$ per 1000 plants, postpaid. All orders are filled by the 100 and not in lots of less than even hundreds like 350 or 450 , etc. Prices by express, you paying express charges, in lots of 1000 to 4000 plants at $\$ 2.00$ per $1000 ; 5000$ or more at $\$ 1.75$ per 1000. Plants weigh about 25 lbs. per 1000 , packed for shipment.

\section{Other Vegetable Plants}

TOMATo. (Ready in April). Dwarf Cham pion, Dwarf Stone, McGee, Beauty and Early Jewel. Price, 25 plants, 25c; 100 plants 50c; 1000 plants, $\$ 4.00$, postpaid.

PEPPER. (Ready in April). Chinese Giant, Bell or Bull Nose and Long Red Cayenne. Price, 25 plants, $45 \mathrm{c} ; 100$ plants, $\$ 1.50$, postpaid.

EGG PLANT (Ready in April) Black Beauty. Price, 25 plants, 45c; 100 plants, $\$ 1.50$, postpaid.

SWEET POTATO SLIPS. (Ready late in April or early May). Porto Rican Yams. Price, 100 plants $50 \mathrm{c} ; 500$ plants, $\$ 2.25$ 1000 plants, $\$ 4.00$, postpaid.

\section{NOTICE}

CABBAGE AND ONION PLANTS. In ome instances, account of bad weather or other causes, we ship the above plants to you direct from our growing station. So, in case your plants do not arrive with your order for seed, you may expect them a few days later. 


\section{Nicholson's Tested Field Seed}

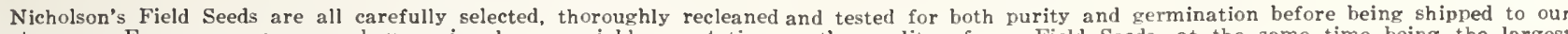

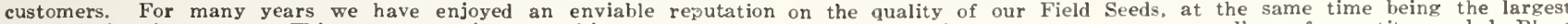

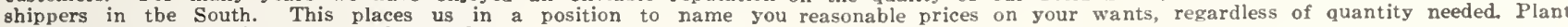
Nicholson's Tested Field Seeds for Better Crops.

\section{Nicholson's Alfalfa Seed}

"A nearly perfect forage crop" are the words used by the United States Department of Agriculture in describing Alfalfa, at the same time stating that a great portion of the Alfalfa of the country is utilized as hay and only 30 to 40 days of good growing weather are usually required to produce sufficient growth for a hay crop.

The above description places Alfalfa at the top of the list, both as a forage and hay crop.

While growing, Alfalfa puts nitrogen in the soil, in this manner enriching the land. It is possibly tbe most profitable of all permanent crops.

Many successful Alfalfa growers make it a habit to run a harrow over their fields in crisscross fashion after cutting. This helps to keep down the weeds and encourages a moje ravid growth. This metbod will not hurt the roots of your plants. Alfalfa can be cut at any time from start of bloom stage to the time the plants are in full bloom. If cut in the earlier stages the hay is slightly ricber in protein, but later cutting seems to help the long life of your field, as well as making a slightly heavier yield.

The seed should be sown bioadcast at the rate of 20 pounds to the acre in February March and April. Can also be planted in Sep. tember, October and November.

Your soil should be clean and well prepared, but firm. Cover the seed about one inch deep with harrow. Firming the land by the use of a roller after planting will help you to get a good stand, as well as a more uniform growth.

By all means, inoculate your seed before planting with Nitragin. We strongly recommend the use of a Cahoon Seed Sower when planting, so as to get an even and uniform stand.

(MEDICAGO SATIVA)

Inoculate Seed With Nitragin

NICHOLSON'S "P U R I T Y BRAND" FANCY. This is the finest quality of American-grown Alfalfa seed that we are able to buy. It is bright and of fine quality, and thoroughly recleaned and tested for purity and germination. Lb., $35 \mathrm{c}$; $2 \mathrm{lbs} ., 65 \mathrm{c}$, postpaid. Not prepaid, 20 lbs., $\$ 3.75 ; 50$ lbs.. $\$ 8.50$; 100 lbs., \$16.50. Ask for prices in larger quantities.

FANCY ALFALFA. This is a first-class quality of Alfalfa seed, and is the kind planted by the average farmer. Lb., 35c:? lbs., $60 \mathrm{c}$, postpaid. Not prepaid, $20 \mathrm{lbs} ., \$ 3.50$; 50 lbs., \$8.00; 100 lbs., $\$ 15.50$. Ask for prices in larger quantities.

NICHOLSON'S FANCY HAIRY PERU. VIAN ALFALFA. Native of Peru. Fspecially adapted for the South and the great Southwest, and is particularly recommended for our own State of Texas. In some sections where mild winters prevail, Hairy Peruvian Alfalfa is cut for hay the entire year. This is certainly a wonder crop and is giving splendid results in Texas and Mexico. Price, lb., 35c; 2 lbs., 65c, postpaid. Not prepaid, 20 lbs., \$3.75: 50 lbs., $\$ 8.50 ; 100$ lbs., $\$ 16.50$.

\section{Nicholson's Tested Clover Seed}

\section{Inoculate Seed with Nitragin}

Some varieties of Clover grow better in the South than others. We list only the varieties that, to our own knowledge, will produce and do well on our Southern soil. It must be made most emphatic that all Clovers far outclass the non-legume crops of the farm for building up the soil. The qualities making them useful in this respect are their ex. tensive root systems and their power to gather nitrogen from the air. Experiments show that 30 to 50 per cent of the fertilizing value of the entire crop of Clover is in the roots and stubble which add humus to the coil. A good crop of Clover will add to the soil in a season 200 pounds of nitrogen to the acre. Since the nitrogen is taken from the air, it represents a profit in the form of fertilizer for the land. It is the kind of fertilizer that costs so high in commercial fertilizer.

The use of Clover makes possible better systems of crop rotations, because some insects and fungous diseases do not affect Clovers like they do grains and other crops. All varieties of Clover have exceptionally high value as feed, containing protein, which is needed to build up muscle and beef and to increase the yield of milk.

Treat all Clover with Nitragin before sowing. For prices of Nitragin, see page $\mathbf{6 5}$.

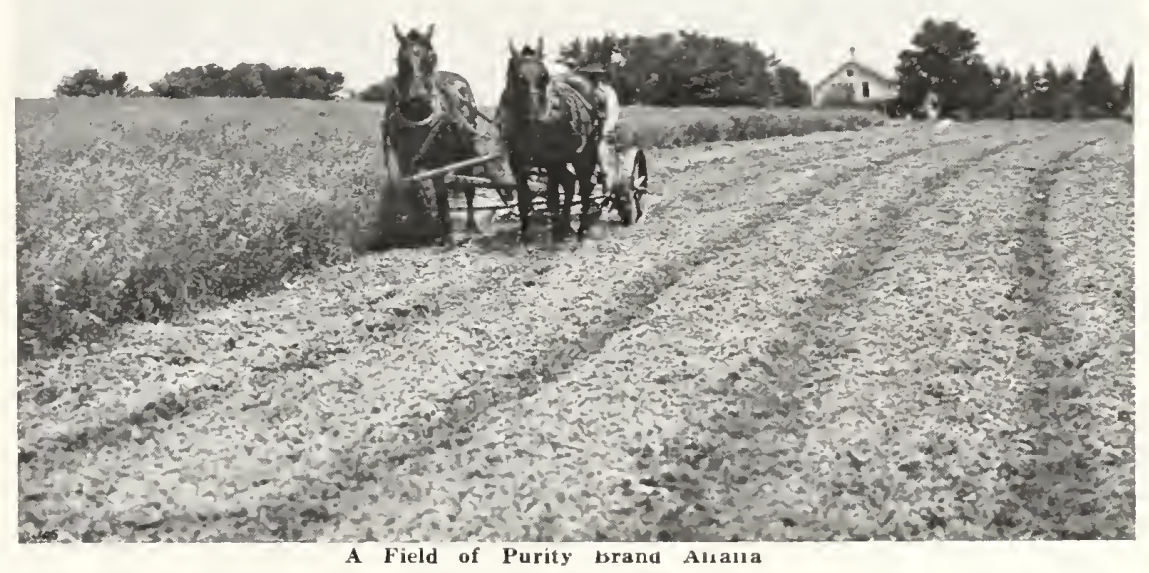

ALSIKE OR SWEDISH CLOVER. A hardy variety of Clover that does not winter-kill. Grows better on moist land than other varieties of Clovers and is suitable for either hay or pasture. When sown with other grasses it forms a thick undergrowth and greatly increases the yield. If sown by itself, plant 10 to 15 pounds per acre. It is best, however, to sow with other grasses and Clovers and in this case, plant about 2 pounds per acre. Lb., 40c; 2 lbs., $75 c$, postpaid. Not prepaid, lb., 30c; 10 lbs., \$2.75. Ask for prices on larger quantities.

IMPORTED HOP CLOVER (Trifolium dubium or minus). Also called English Red Suckling Clover, but bears a small, yellow bloom. Makes a rather upright growth under practically all conditions except where the plants are single and there is ample opportunity for spread, the growth is then rather spreading. Best results come from fall sowing in the South. Grows 12 to 15 inches high. Lb., 40c: 2 lbs., 75c, postpaid. Not prepaid, Ib., 30c; 10 lbs., \$2.75. Please ask for prices in larger quantities.

HUBAM CLOVER (Melilotus Annua). This is annual White Flowering Sweet Clover. A most rapid grower that will even crowd out weeds, if planted broadcast. Excellent for pasture or hay, also does well when planted with oats or other small grains. Very similar in food value and chemical analysis to the biennial White Flowering Sweet Clover. Lb., 40c; 2 lbs., 75c, postpaid. Not prepaid, lb., 25c; 10 lbs., \$2.25. Please ask for prices in larger quantities.
CRIMSON CLOVER (TTifolium Incarna tum). An annual winter growing legume Sow in August, September and October. Sow 20 pounds to the acre. Adapted to sandy loamy and even clay soils. Lb., 30c: 2 lbs. $50 \mathrm{c}$, postpaid. Not prepaid, $1 \mathrm{~b}, 20 \mathrm{c} ; 10 \mathrm{lbs}$ \$1.75. Ask for prices in larger quantities.

LADINO CLOVER (Trifolium Repens) Ladino, or Giant White Clover, is a larg form of the ordinary White Dutch Clover It is a perennial and seems to hold its ow in pastures wherever tried. Its roots do no go very deep into the soil. Ladino Clover makes a growth of 8 to 12 inches in height. Five or six pounds of seed are sufficient to plant an acre if your soil is clean and free of weeds; when used in a mixture, one or two pounds to the acre is enough. Plant in fall or spring. Price, lb., $\$ 1.10 ; 2$ lbs., $\$ 2.10$, postpaid. Not pepaid, lb., \$1.00; 10 lbs., $\$ 9.50$.

JAPAN CLOYER OR LESPEDEZA STRI. ATA. Sow in the fall or spring at the rate of 25 pounds to the acre. To obtain a good stand, disc harrow your land, then scatter the seed on top and roll the field. This will cover the seed enough. Lespedeza is especially adapted to Southern climates, where, even in the driest seasons, it thrives on practically any soil. It is classed among the most valuable hay and pasture for the South. Wel adapted for use as a green manure by turnNot prepaid, lb., 30c; 10 lbs., \$2.25. Ask for prices on larger quantities. 


\section{Bur Clover}

\section{Inoculate Seed With Nitragin}

Bur Clovers are annual legumes and seem to be more universally used in Texas and the South, and with a greater degree of success, than most any other clover.

It is one of the finest crops for winter pasture, and, being a legume, it also puts nitrogen in the soil while growing. This Clover is used extensively and does well mixed with other clovers and grasses for permanent pasture. It also thrives on a wide range of soils, including sandy loams and lime-clad hilis.

Bur Clover may be grown advantageously on Bermuda sod, the two plants furnishing almost continuous grazing. In this case the seeds are either sown early without covering, or else the Bermuda sod is so plowed as not to destroy the roots. Use five to ten pounds of seed in the bur or four to six pounds of the hulled seed per acre for planting on Bermuda sod.

For additional information on Bur Clovers, write the United States Department of Agriculture, Washington, D. C., and ask for Farmers' Bulletin No. 693.

KOREAN LESPEDEZA. Tested by us the past year, it did exceptionally well on black land, producing a wonderful growth regardless of the hot and dry summer. A mammoth early variety, vigorous grower, maturing about 30 days earlier than other kinds, which makes it an ideal legume to grow over a wide area, further north and in high altitudes. Is a heavy bearer of seed, which does not shatter from storm as readily as other.s, giving a longer period to harvest seed. Lb., $45 \mathrm{c} ; 2$ lbs., $85 \mathrm{c}$, postpaid. Not prepaid, Ib. $35 c ; 10$ lbs., $\$ 3.00$. Ask for prices on larger quantities.

KOBE LESPEDEZA. The mammoth late variety, vigorous grower, maturing about the time of common Lespedeza, making much more growth. Demonstrations have proven Kobe to be superior to other varieties in the production of seed and hay. Tested by us the past year, it did exceptionally well on black land, producing a wonderful growth regardless of the hot and dry summer. Lb. 45c; 2 lbs., 85c, postpaid. Not prepaid, lb. $35 \mathrm{c} ; 10 \mathrm{lbs}$., $\$ 3.00$. Ask for prices on larger quantities.

BLACK MEDIC (Medicago Lupulina). Black Medic is also known in some sections as Yellow Trefoil. It is a good spreading plant for winter growing. Has a bright yellow bloom, similar in shape but smaller in size than White Dutch Clover. The plant gets its name from the black color of the mature seed pods.

It re-seeds itself freely and yields a very nutritious pasturage. Black Medic has proven to be one of the most valuable additions to Bermuda pastures on lime soils and is certainly worthy of extensive trial on all types of soil.

The usual rate of seeding is 15 pounds to the acre. Sow the seed in September, October or the first half of November, also in February and March. Planted on established pastures or in mixtures with other grasses and clovers, two or three pounds to the acre are sufficient. Will re-seed itself even under rather close grazing. Lb., 45c; 2 lbs., 80 c, postpaid. Not prepaid, lb., $35 \mathrm{c} ; 10$ lbs., $\$ 3.20$. Please ask for prices in larger quantities.

MELILOTUS INDICA (Annual Yellow Blossom Sweet Clover). Sometimes called Sour Clover, and is becoming very rapidly recognized as a wonderful legume, especially adapted to plowing under for green manure. When planted in the fall, it grows all during the winter and is just the thing to build up run-down soil and improve the yield of crops that would be planted on the land the following spring. It is used very extensively to sow to plow under as a green manure crop in the orchards of California and is now being planted for the same purpose in Texas. It also prevents erosion during the rainy season. Price, lb., 20c; 2 lbs., 35c, postpaid. Not prepaid, lb., 10c; 10 lbs., 90c. Ask for prices on larger quantities.

PERSIAN AND WHITE DUTCH CLOVER, MIXED. A combination of two excellent clovers that thrive well in moist or shady spots. Does exceptionally well near the Gulf Coast. Price, lb., 45c; 2 lbs., 80c, postpaid. Not prepaid, lb., 35c; 10 lbs., \$3.25. Please ask for price on larger quantities.

\section{White Flowering Sweet Clover}

(Melilotus Alba). White Flowering Sweet Clover is a biennial and, as a rule, does not bloom the first year after planting, but the growth is much more rapid the second year. With the stimulus of food stored in the roots and the second year growth starting early in the spring of the second season, you are as sured a good early pasturage or an abundant hay crop.

Sweet Clover is useful for soil improvement for hay to be consumed on the farm, for pas turage, and as a honey plant for the bees. For soil improvement it is very valuable to lime and heavy clay and black lands, not only on account of the luxuriance of stems and foliage, but also because the thick roots, on decaying, improve the drainage and tex ture of the soil.

Sow the seed in September, October and November at the rate of 15 pounds per acre. Can also be planted in the spring.

The first year's growth of this plant should be used for pasturage. The second year's growth can be used for pasturage as early as March-before most summer plants are available-and may be pastured throughout the early summer. To keep the plants from becoming too coarse in their second year and to prolong the grazing season, Sweet Clover pastures should be clipped before the plants bloom freely.

In Texas, this great Clover is especially adapted to the stiff lands, and even clay soils, that are too poor in organic matter to support a thrifty growth of Alfalfa or other clovers and grasses. Such soil will increase greatly in value with each year's growth of Sweet Clover. The preparation of land for Sweet Clover is varied and is very often sown in one of the following manners:

1. Sow broadcast on clean land without any preparation and cover lightly with a harrow.

2. Plant as a catch crop when sowing grain or among the young growing plants of fall-sown grain.

3. Sow two bushels of oats to the acre and after doing this sow about 15 pounds of Sweet Clover on the same soil, so as to get an even distribution of the two seeds. After the oats are cut in the summer, the Clover will then begin to grow rapidly and under normal conditions.

Growing Sweet Clover is the best known method of building up wornout lands. Black lands especially will respond to Sweet Clover where commercial fertilizer fails.

For further information in regard to Sweet Clover, write the U. S. Department of Agriculture at Washington, D. C., and ask for their Bulletin No. 797.

NICHOLSON'S FANCY WHITE FLOWERING SWEET CLOVER (Hulled and Scarified Seed). Price, lb., 25c; 2 lbs., 45c, postpaid. Not prepaid, lb., 15c; 10 lbs., $\$ 1.25$. Please write for prices on larger quantities.
CALIFORNIA GROWN BUR CLUVER. Fancy hulled seed. Lb., 35c; 2 lbs., 65c, postAsk for prices on larger quantities.

EARLY SOUTHERN BUR CLOVER IN BUR Lb. 35c: 2 lbs 65c postpaid Not prepaid, lb., 25c; 10 lbs., \$1.75. Ask for prices on larger quantities.

SPOTTED LEAF BUR CLOVER IN BUR. Lb., 35c: 2 lbs., 65c, postpaid. Not prepaid, lb., 25c; 10 lbs., $\$ 1.75$. Ask for prices on larger quantities.

SMOOTH BUR CLOVER IN BUR. This is a very good variety for sheep pasture, as the burs are smooth and will not mat the wool. Will do well also for cattle and hog pasture. Lb., 30c; 2 lbs., 55c, postpaid. Not prepaid, lb., 20c; 10 lbs., \$1.75. Ask for prices on larger quantities.

RED CLOVER (Trifolium Pratense). As a rule lives two years, very popular in many sections. Sow broadcast 15 pounds to the acre or 8 pounds to the acre in drills. Does well the year around on rich moist land. Sow in fall or spring. Price, lb., 45c; 2 lbs., 80c, postpaid. Not prepaid, $1 \mathrm{~b} ., 35 \mathrm{c} ; 10$ lbs., $\$ 3.00$. Please write for prices on larger quantities.

SUBTERRANEAN CLOVER (Trifolium Subterraneum). Subterranean Clover is an annual which, on account of re-seeding itself, is permanent when once established.

The lower shoots force their seed pods into the soil, from which the Clover probably derives its name. This insures re-seeding for the next year.

Cattle and sheep are extremely fond of Subterranean Clover and even at the end of the season, when the plants have dried, they will seek it out when feeding over the pasture.

In due time, Subterranean Clover will double or treble the carrying capacity of poor or medium quality land, so you will readily see just what a wonderful soil improving plant it is.

For more information on this clover, we suggest that you write the Texas Agricultural \& Mechanical College, College Station, Texas, and ask for Circular No. 37. Lb., \$1.00; 2 lbs., $\$ 1.90$, postpaid. Not prepaid, lb., 85c; 10 Ibs., $\$ 8.00$. Please write for price on larger quantities.

WHITE DUTCH CLOVER (Trifolium Repens). White Dutch Clover is a long-lived perennial. It is very valuable as a grazing plant; incidentally, valuable as a honey plant, and for soil improvement You will also find this same Clover planted with grasses for a winter lawn-and in heavily shaded spots, through the summer. White Dutch Clover thrives over most of the cotton belt. It requires a fairly moist soil, with a preference for loamy fertile soils, Lb., 65c; 2 lbs., \$1.25, postpaid. Not prepaid, lb., 55c; 10 lbs., $\$ 5.00$.

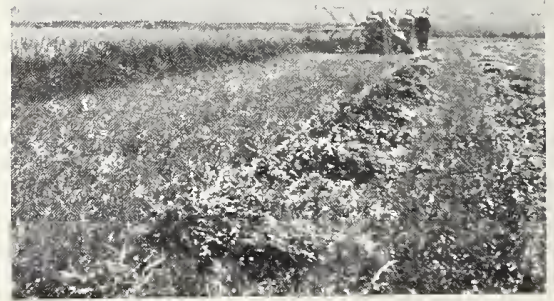

A Field of Sweet Clover 


\section{Tested Seeds for}

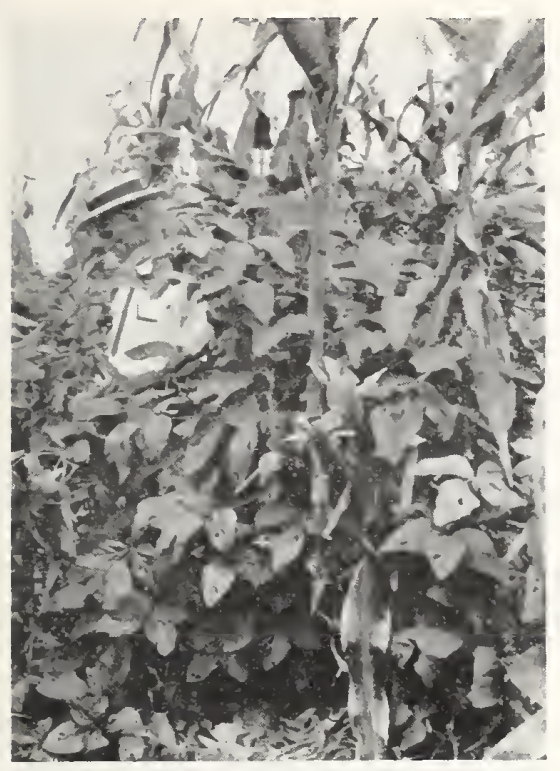

Soy Beans in Corn

\section{Soy Beans}

Generally speaking, the Soy Beans require the same soil as corn, although Soy Beans will make a very satisfactory growth on poorer soil than will corn if the seed is properly inoculated. Soy Beans are wonderful soil improvers; they belong to the family of legumes, therefore have the power of taking nitrogen from the air and storing that most valuable of all plant foods in the soil.

MAMMOTH YELLOW. The use of Soy Beans is increasing rapidly all over the country and especially in the South where our farmers are becoming more interested in stock raising for real profit and, at the same time, increasing the fertility of their lands. For cutting as hay and as a soil builder, sow at the rate of $21 / 2$ bushels to the acre broad. cast. For growing Beans, sow from 15 to 30 lbs. per acre in drills $3 \frac{1}{2}$ feet apart. Soy Beans should be planted in April, May, June and July. Lb., 25c: 2 lbs. 45c, postpaid. Not prepaid, 20 lhs., $\$ 1.50$. Ask for prices on larger quantities.
NOCLLATE ALL LEGUMES

\section{Nicholson's Field Beans}

\section{Laredo Soy Beans}

A new variety of outstanding worth, par. ticularly for making hay. The Laredo makes many slender branches and the plants are leafy, both of which go to make an ideal Bean for hay. It is particularly adapted to sections where wilt and nematode are prevalent as it has proven resistant to these troubles.

As a soil builder it ranks favorably with other summer legumes. The sfeds of the Laredo Bean are very small. One bushel, 60 pounds, will plant about 10 acres in $21 / 2$-foot rows planting three to four seeds to the foot in drills. The proper time to cut for hay is when the Beans are about half matured. Lh. $25 \mathrm{c} ; 2$ lhs., $45 \mathrm{c}$, postpaid. Not prepaid, 20 lhs., \$1.50. Ask for prices on larger quantities.

\section{Velvet Beans}

Another great forage plant and soil builder. Velvet Beans make a greater growth of vines than any other known forage plant in the same length of time, far surpassing any of the cow peas in growth. They should be planted in rows 3 to 5 feet apart, at the rate of one-half bushel to three pecks per acre. They are also fine for planting in corn. These Beans make wonderful grazing for all kinds of stock, and even after frost has killed the vines, stock will eat vines and beans and fatten on them. Such vines and roots as are left by stock should be plowed under, as they are very rich in fertilizing value.

EARLY SPECKLED OR 100-DAY VINING VARIETY Lb. 20c; 2 lbs, $35 \mathrm{c}$, postpaid Not prepaid, 20 lbs., \$1.50. Ask for prices on larger quantities.

\section{Mung Beans}

An exceptionally good hay crop and a wonderful soil improver and very drought resistant. About 5 pounds will plant an acre. Best results are obtained when planted in $21 / 2-$ to 3 -foot rows, 4 to 5 inches in the in April. Seed can be harvested as Soy Beans or picked by hand Lb., $40 \mathrm{c}$; 2 lbs. 75 , postpaid. Not prepaid, 5 lbs., \$1.00; 20 lbs. $\$ 3.50$. Ask for prices on larger quantities.

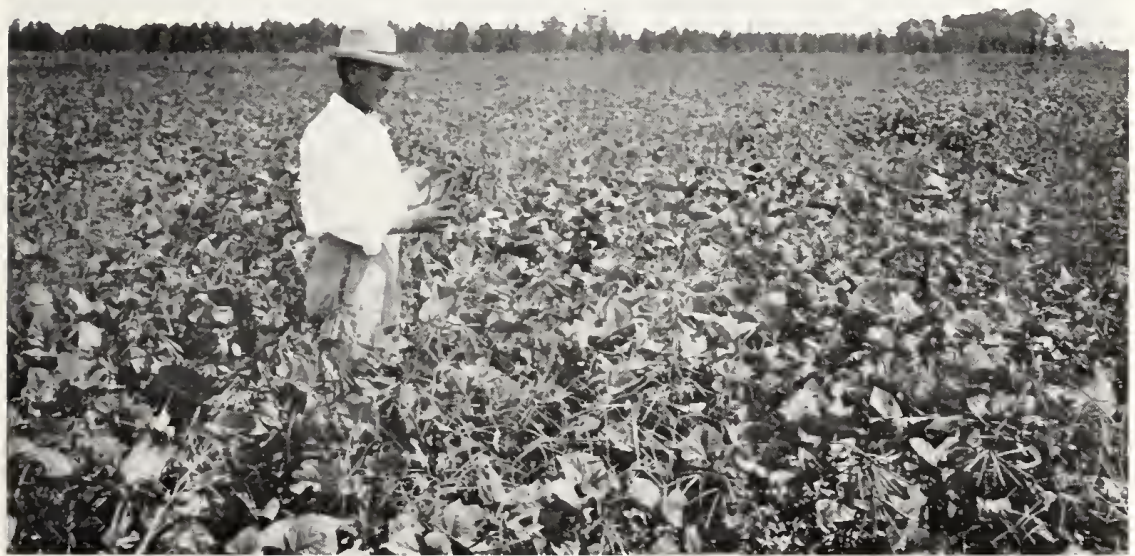

A Field of Mung Beans

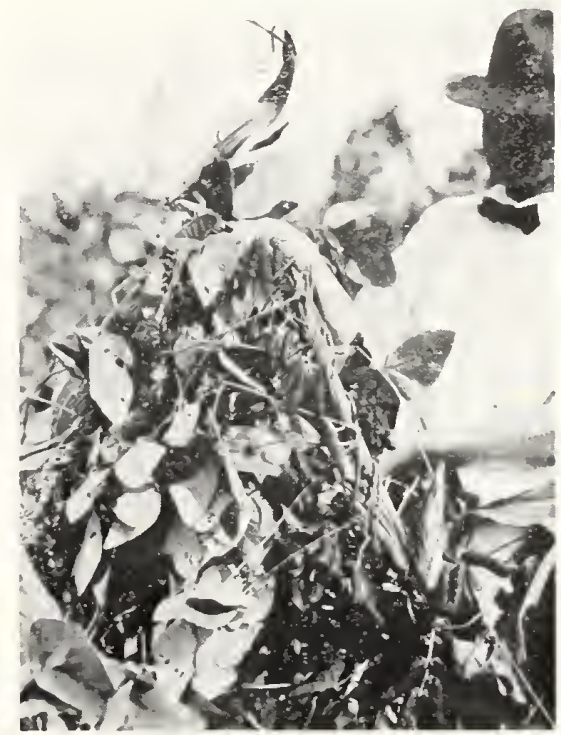

Velvet Beans in Corn

Legumes that are worth planting are worth inoculating.

\section{Vetch}

Vetch is another splendid variety of forage plant and is rapidly gaining popular favor with farmers and stock raisers throughout the country. It is very hardy, is valuable as a winter cover crop to prevent leaching and for forage and fertilizer purposes.

HAIRY WINTER VETCH. May be sown either in spring or fall. For fall planting should be sown in Aucust or September: it will cover the ground before frost and make a valuable winter forage crop. When sown in spring it is ready to cut by July; the second growth will make excellent pasture for late summer and fall use. Sow 50 to 60 pounds of Vetch with the same amount of oats, using the oats to support the Vetch Lb., 35c: 2 lbs., 55c, postpaid. Not prepaid, lb., 20c; 20 lbs., \$3.00. Ask for prices on larger quantities.

OREGON VETCH. About the same as Hairy Vetch excent not quite so hardy. Sow in spring as well as fall. Lb., 25c: 2 lbs. 40c, postpaid. Not prepaid, lb., 15c; 20 lbs., $\$ 2.25$. Ask for prices on larger quantities.

PURPLE VETCH. Resembles the Hairy Vetch, having a purple flower. It is slightly less hardy than the other Vetches, but goes
through ordinary winters very successfully. Sow the same as Hairy Vetch. Makes fine winter pasture. hay in the spring and is an excellent green manure crop to plow uncows in the spring is to sow a mixture of Vetches, Austrian Winter Peas and Oats and cut these as needed. Lb., 30c; 2 lbs., 50c postpaid. Not prepaid, lb., 20c; 20 lbs. \$2.50. Ask for prices on larger quantities. 


\section{Nicholson's Austrian Peas}

Maintaining soil fertility is one of the farmer's most perplexing problems. This wonder plant makes a heavy vine growth that will decay very rapidly when plowed under. The same soil is then in shape for planting other crops.

As a cover crop, it only needs ten to twelve pounds of growth to each 10 feet square, to plow under for fertilizer. It therefore can be planted in South Texas and Louisiana as early as the first of January; in North Texas, January 15 to February 1. Other crops planted on the same soil, following the plowing under of Austrian Peas, will show a tremendous increase in yield. Cattle, sheep and hogs will graze on a field of Austrian Peas and enjoy it. A greater tonnage of hay can be obtained when planted with oats, the oats acting as a support for the peas and encouraging their growth.

The most economical manner is to plant Austrian Peas in rows. In doing this, one should plant in three-foot rows such as in planting corn, then turn back and plant between the rows, thus giving you 8 -inch rows when finished. It requires only 30 pounds to plant an acre in this way.

If wanted for pasture or hay, sow broadcast, 60 pounds to the acre; also 60 pounds to the acre when sown with an ordinary grain drill.

If you desire to sow with small grain such as oats, we suggest sowing one or two bushels of oats to the acre about as deep as the drill will put the oats, and then plant back over the oats with the Peas at the rate of 30 to 40 pounds to the acre, putting the Peas just deep enough to cover good, without disturbing the oats. This system of planting is necessary, as a mixture of peas and oats will not mix eveniy enough to drill out uniformly. Sow' in fall or early spring. Lb., 25c: 2 lbs., 45c, postpaid. Not prepaid, lb., 10c; 20 lbs., $\$ 1.75$. Ask

\section{Canada Field Peas}

Plant during the months of October and November, and again in the early spring. They improve the soil by gathering and storing nitrogen. Yield heavy crops that may be grazed or made into hay, that stock eat greedily and thrive on. Grow 4 to 6 feet high, but can be grazed when 6 to 10 inches high. Pasturing the Peas makes them stool out better. It is a good idea when sowing the Peas to mix a bushel of oats, barley, or wheat with 50 pounds of Peas per acre. This makes a fine mixture and makes good hay. If sown alone, sow about 75 pounds per acre, broadcast. Crop of this kind is splendid to plow under for green manure. Also used as a table Pea and is only excelled by the English Pea. Lb., 25c; 2 lbs., $45 \mathrm{c}$, postpaid. Not prepaid, 20 lbs., $\$ 2.00$. Ask for prices on larger quantities.

\section{CERESAN \\ For Cotton}

1-Controls damping-off, caused by seed-borne and certain soil-borne organisms and seed rotting.

2-Reduces damage caused by angular leaf spot, anthracnose and boil rot.

3-Makes possible earlier planting and produces heavier stands.

4-Generally produces heavier yields of better quality.

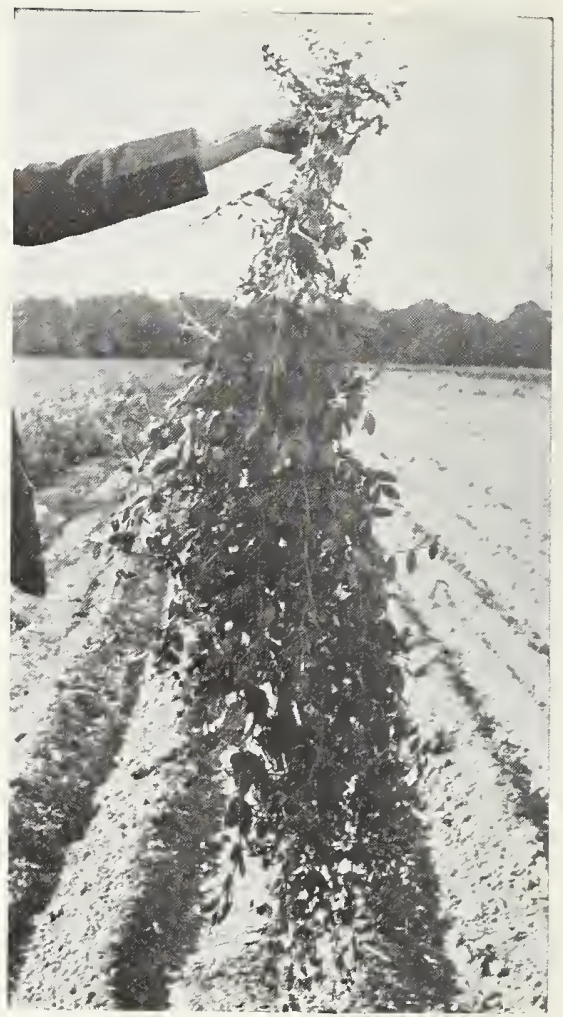

Nicholson's Austrian Peas

\section{Cotton Seed}

\section{Harper Cotton}

The King of the Mebane strains

We believe Harper's State Registered Seed to be the greatest cotton seed value, quality and price considered, that has ever been offered to Southern cotton growers.

Everything You Need in an Improved Cotton. Rapid Growth-Big Bolls-Easy to Pick-

Drouth Resisting-Heavy Yield-Long and Strong Staple-Early Maturity-Storm Proof-38 to 42 Per Cent Lint-Long Limbs and Short Joints.

The first step toward a profit on your Cotton crop is to plant only the best type of high producing Cotton, so you may count on the largest possible yield of high grade lint per acre. Harper's Improved Pedigreed Seed is a native Texas Mebane Cotton well acclimated to Southern conditions. It does well on all types of soil in the Southwest.

The varietal purity of this Cotton is unexcelled and we believe it is the best strain of Mebane Cotton to be had. We carry a large stock of these seeds. Grown by Robt. M. Harper, a State Registered Cotton Breeder, and ginned on his exclusive gins where no other is ginned. All seed shipped in Harper's sealed, trade-mark bags. Under normal conditions, 1,200 to 1,300 pounds of seed cotton produces a bale of 510 pounds of good staple Cotton.

Price, 3 to 5 bu., $\$ 1.35$ per bu.; 6 bu. or more, $\$ 1.25$ per bu.

Freight charges prepaid to any railroad station in Texas.

No order accepted for less than 3 bushels.

\section{Watson Cotton \\ Improved from Mebane}

The Watson Cotton has been bred, grown and developed in Dallas County, Texas, by Ferris Watson, a State Registered Plant Breeder.

The Watson Cotton, on account of its many desirable characteristics, has now become one of the most popular varieties grown in the Southwest.

The Watson Cotton has medium foliage, is early maturing, has a large boll, and is storm proof with a staple of 1 to $11 / 16$ inches.

Not since the original Mebane was first placed on the market has a cotton been received with so much favor. Perhaps no other cotton has proven as well adapted to the different soils and sections as the Watson Cotton.

Seed put up in three bushel bags, all of which have been inspected and certified to by the State Department of Agriculture.

Price, \$1.25 per bu., freight prepaid Texas points. Minimum shipment 3 bu. at freight paid prices.

\section{Other Varieties of Cotton Seed}

We can also supply, if wanted, the following varieties of Cotton seed: Lone Star, Kasch, Acala, Rowden and other varieties. If interested in any of these, ask for prices and state quantity wanted. 


\section{Tested seeds for}

\section{Cow Peas Make Poor Land Rich---Make Good Land More Productive A Splendid and Nutritious Green Forage or Hay Crop}

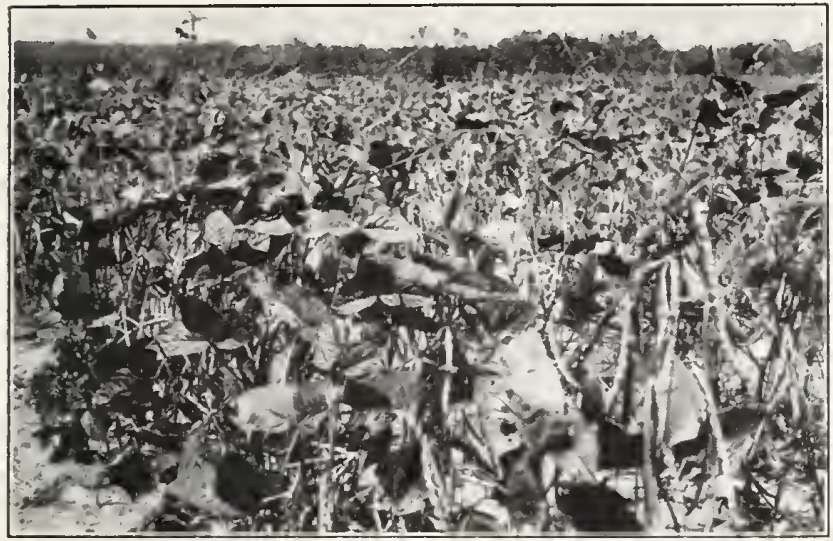

A Field of Cow Peas

BRABHAM. Seeds are similar in appearance to Whippoorwill, only much smaller and do not require to be seeded as thickly is other kinds. Are very resistant to disease, practically free from nematode, vigorous in growth holding their foliage well and are particularly valuable to sow in East Texas particularly valuable to sow in East Texas spread orchard diseases. Lb., 25c: 2 lbs., $45 c$ postpaid. Not prepaid, lb., 15c; 20 lbs., \$1.75.

BROWN CROWDER. This is a very fine, large variety of Peas and is getting popular as a table Pea throughout Texas and the Southwest. Lb., 25c; 2 lbs., 45c, postpaid. Not prepaid, lb., 15c; 20 lbs., \$1.50. Ask for prices on larger quantities.

WHITE CROWDER. A delightfully flavored variety for table use. We have a limited supply this year. Lb., 30c: 2 lbs., $55 \mathrm{c}$, postpaid. Not prepaid, lb., $15 \mathrm{c} ; 20$ lbs., $\$ 2.50$. Please write for prices in larger lots.
LARGE WHITE BLACK EYE. The large Black Eye Peas are more prolific, better fla vored and bring a higher price than most any other variety. Where Peas alone are wanted the planters will probably find this more desirable than any other kind. Lb. 25 c 2 lbs $45 \mathrm{c}$, postpaid. Not prepaid, lb., 15c; 20 lbs., \$1.75. Ask for prices on larger quantitics.

CLAY. The seeds of this variety are me dium sized and cream or clay colored; vines grow long and very leafy. One of the best for enriching soil. Lb., 20c; 2 lbs., 35c, postpaid. Not prepaid, lb., $10 \mathrm{c}$; 20 lbs., \$1.25. Ask for prices on larger quantities.

CREAM OR LADY. This is a very fine variety for table use; is also a great soil builder. Lb., 25c; 2 lbs., 45 , postpaid. Not prepaid, lb., 15c: 20 lbs., $\$ 1.75$. Ask for prices on larger quantities.

\section{Cow Peas}

\section{Sesbania---The Rapid Growing Annual Legume}

A most vigorous growing annual legume, it thrives in warm weather and will grow on alkali and other poor soils, where practically no other plants do well It makes a tall, slender stalk, growing as high as eight feet, the limbs spreading from three to five feet. The seed should be sown broadcast at the rate of about 30 pounds to the acre at bean planting time, or when the ground is sufficiently warm. It requires the same planting and growing weather as cow peas. Sesbania, in its rapid growth, frequently grows as much as a foo per week, requiring only eight weeks from the time of germination to time of plowing under; this should be done when the seed is in the dough. Broadcast the seed similar to wheat and we recommend inoculating the seed with NITRAGIN before sowing.

Sesbania has no use at present other than its fertilizer value; it will thrive in wet soil; its large root system is always covered with nodules and it not only fertilizes, but the large roots also help break up the soil. It is an annual, so there is no danger of it becoming a pest or even spreading when the seed is not allowed to mature.

Sesbania is fast becoming the one fertilizer crop in the Southern States for summer growing. It is used in the Rio Grande Valley of Texas as a protection to young citrus trees in hot weather, at the same time creating humus and nitrogen which adds to the richness of the soil.

Robert Nicholson Seed Co.,

Dallas, Texas.

Gentlemen :

Webb County, Texas.

Regarding Sesbania, I planted one acre last season, using twenty pounds of seed. I found it to be an extra fine cover crop and wonderful soil builder; besides I turned under 14 tons of green manure from this one acre.

It required watering and matured in about eight weeks. It grew to a height of eight feet and carried plant food equivalent to 400 pounds of fertilizer per acre.
Yours very truly.

J. S. WESTBROOK.
Think of a plant yielding fourteen tons of green manure per acre to turn under - this equals 400 pounds of commercial fertilizer. Read what Mr. J. S. Westbrook of Laredo, Texas, has to say about Sesbania.

Price: lb., 35c; 2 lbs,, 60c, postpaid. Not prepaid, lb., 20c; 10 lbs., \$1.50. Ask for prices on larger quantities.

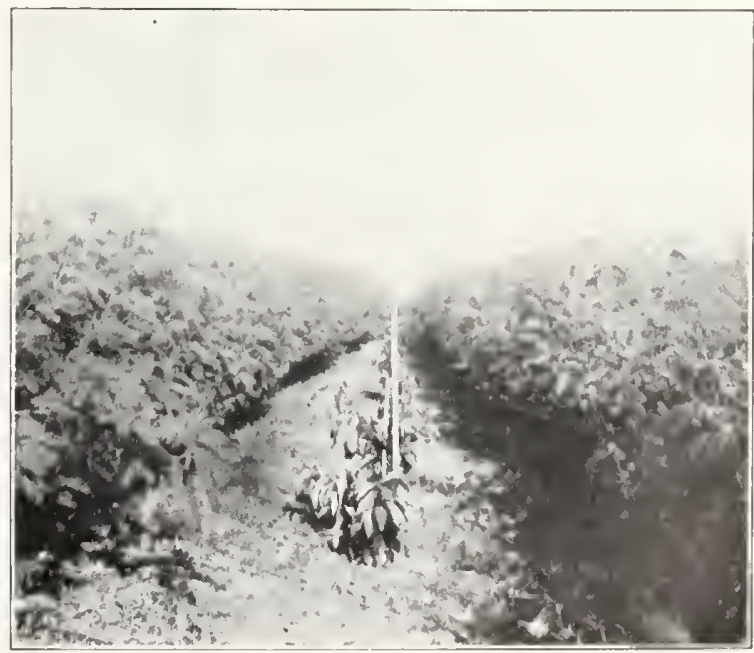

A Field of Sesbania 


\section{Nicholson's Tested Seed Corn}

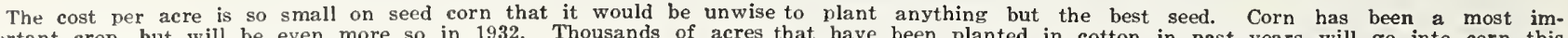

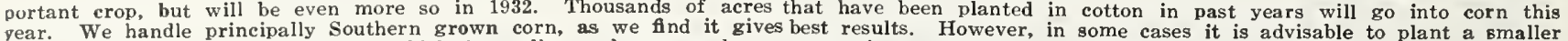

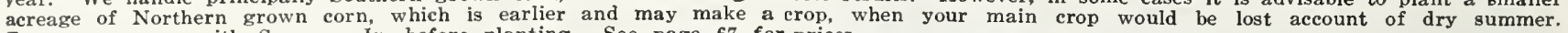
Treat your corn with Semesan $J r$. before planting. See page 67 for prices.

\section{Southern Grown}

NICHOLSON'S DROUGHT RESISTANT CORN. A native of Texas and has been bred a number of years to meet Texas conditions. Makes a short, sturdy, vigorous stalk, about 5 feet tall. Its deep rooting system makes it storm and wind resistant and a very heavy producer. One of its outstanding features is early maturity. Roasting ears have been gathered in 80 days after planting. Stands up well. Has long shank on ear, which turns down and protects the ear from rain. Has heavy broad blades, many of them being 5 to 7 inches wide. Ears are large: kernels medium size and depth, showing slight dent and above average size, many of them one pound. Corn white, cob white. Lb., 30c; 2 lbs., 50c, postpaid. Not prepaid, pk., \$1.00; bu. \$3.5. Ask for prices on larger quantities.

HASTING'S PROLIFIC. Makes two or more ears to the stalk: requires 120 days to mature. Shells out exceptionally heavy and is good for roasting ears, meal or stock feeding. Lb., 30c; 2 lbs., 50c, postpaid. Not prepaid, pk., 85c; bu., \$2.75. Ask for prices on larger quantities.

CHISHOLM WHITE RED COB. Large ear of the finest Corn. Grains very deep, wide and thick: red cob; very popular wherever tried. We recommend this as being the finest variety of White Red Cob Corn. Matures in 100 to 110 days. You will make no mistake in planting the Giant White Red paid, pk., 75c: bu. \$2.50. Ask for prices on larger quantities.

GIANT STRAWBERRY. Has always done well in Texas. It is large-eared and a very heavy cropper. Fine all-purpose Corn. Lb., 25c; 2 lbs., 40c, postpaid. Not prepaid, pk., $75 \mathrm{c}$; bu., \$2.50. Ask for prices on larger quantities.

GIANT YELLOW DENT. The finest yellow Corn for the Southern planter. Has a large, deep grain, good sized ears. We sell more of this variety than any Corn we handle and recommend it as the best yellow, Southern krown Corn. Our seed is all carefully selected. It will please you. Lb., 25c; 2 lbs., 10c, postpaid. Not prepaid, pk.,
\$2.50. Ask for prices on larger quantities.

SURECROPPER. An early maturing and drouth-resisting Corn, suitable for spring and summer planting, and is considerably used to plant in stubble ground after grain has been cut. Matures in 110 to 120 days. Ears are of good size, stocky and well formed. Lb., $25 \mathrm{c} ; 2$ lbs., $40 \mathrm{c}$, postpaid. Not prepaid, pk., $75 \mathrm{c}$; bu., $\$ 2.50$. Ask for prices on larger quantities.

DWARF MEXICAN JUNE. This Corn is planted very extensively during the months of May, June and July; stands the dry weather and makes a splendid yield with a moderate amount of moisture. Lb., 25c; 2 hu., \$2.50. Ask for prices on larger quantitics.

WHITE WONDER. Immense quantities of this variety have been planted all over Texas for a number of years. Lb., 25c; 2 lbs., 40c, postpaid. Not prepaid, pk., 75c; bu., \$2.50. Ask for prices on larger quantities.

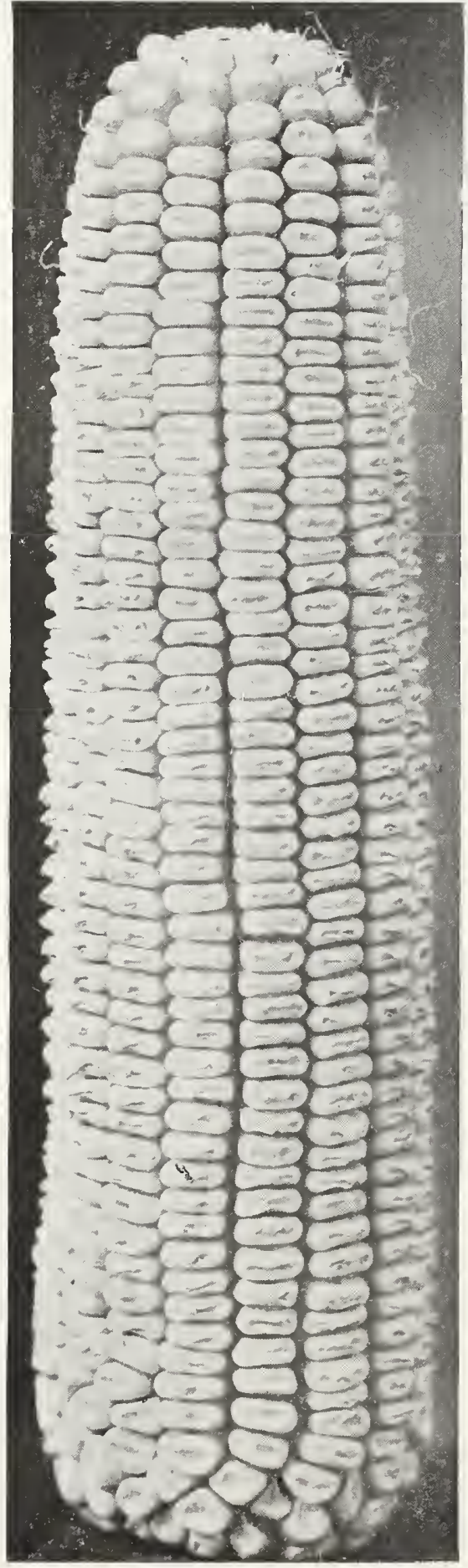

Giant lellow bent
HICKORY KING. Has the smallest cob of any Corn grown. Makes a very large, white, flat grain; largely planted for roasting ears. Lb., 30c; 2 lbs., 50c, postpaid. Not prepaid, pk., 85c; bu., \$2.75. Ask for prices on larger quantities.

IMPROVED SQUAW. A natural drouthresisting variety. Most of the Corn runs to blue and white grains. Makes a first class, large ear, 10 to 12 inches long. Many people plant it late in the season the same as Mexican June Corn. We recommend it highly. Lb., 30c; 2 lbs., 50c, postpaid. Not prepaid, pk., 85c; bu., $\$ 2.75$. Ask for prices on larger quantities.

GIANT BLOODY BUTCHER. A beautiful, large, red grain. A splendid yielder. Lb., 25c; 2 lbs., 40c, postpaid. Not prepaid, pk., $75 \mathrm{c}$; bu., $\$ 2.50$. Ask for prices on larger quantities.

RED JUNE CORN. A red Mexican June Corn that stands the drouth well. The ear is slightly larger than the regular June Corn. Lb., 25c; 2 lbs., 40c, postpaid. Not prepaid, pk., 75c; bu., $\$ 2.50$. Please ask for price in larger quantities.

\section{Northern Grown}

REID'S EARLY YELLOW DENT. A splendid variety. Ears are of good size, witb very deep, bright yellow kernels. Cob is small, stalks grow to a medium height and often produce two ears. Lb., 25c; 2 lbs., 40c, postpaid. Not prepaid, pk., 65c; bu., $\$ 2.25$. Ask for prices on larger quantities.

GOLD MINE. Similar to Silvermine except in color. Fars are of good size and symmetrical; a bright golden yellow color and cob is small. Lb., 25c; 2 lbs., 40c, postpaid. Not prepaid, pk., 65c; bu., \$2.25. Ask for prices on larger quantities.

EARLY WHITE PEARL, Used for roasting ears as well as for field purposes. A little larger, smoother ear; has more fluid in it than Silvermine. Lb., 25c; 2 lbs., 40c, postpaid. Not prepaid, pk., 65c; bu., $\$ 2.25$. Ask for prices on larger quantities.

EARLY SILVERMINE. A standard white variety. Splendid yielder, extremely hardy, will produce well on thin soil. By some, white Corn is considered a surer cropper than yellow. Lb., 25c; 2 lbs., 40c, postpaid. Not prepaid, pk., 65c; bu., $\$ 2.25$. Ask for prices on larger quantities.

\section{Pop Corn}

There is always a good market for Pop Corn, and every Corn grower should plant it. The children and grown folks enjoy Pop Corn and a few rows should be planted for home use.

WHITE RICE. Best variety of white Pop Corn for popping. Lb. 30c; 2 lbs., 55c; 5 lbs. $\$ 1.00$, postpaid. Not prepaid, $10 \mathrm{lbs} ., \$ 1.00$.

LITTLE BUSTER OR JAPANESE HUL LESS. Produces well in the South. Extra small grain and excellent for popping. Pure white and good yielder. Lb. $30 \mathrm{c} ; 2$ lbs., $55 \mathrm{c}$; 5 lbs., \$1.10, postpaid. Not prepaid, 10 lbs., $\$ 1.10$.

SOUTH AMERICAN. A large yellow grain Corn that grows well in Texas. Cream colored when popped and has distinct flavor. Lb., 30c: 2 lbs., 55c: 5 lbs., \$1.00, postpaid. Not prepaid, 10 lbs., $\$ 1.25$.

NICHOLSON'S GOLDEN HEART (SHURPOP). A very tender popping Corn which shows a wonderful expansion on popping. Grows well in Texas and the South. Lb. $30 \mathrm{c} ; 2$ lbs., 55c; 5 lbs. $\$ 1.00$, postpaid. Not prepaid, 10 lbs., \$1.25. 


\section{Tested seeds for Nicholson's Tested Grain Sorghums Saccharine}

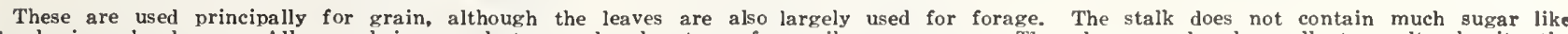

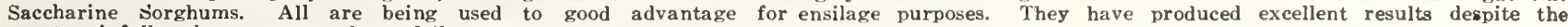
scant rainfall, where corn made a failure.

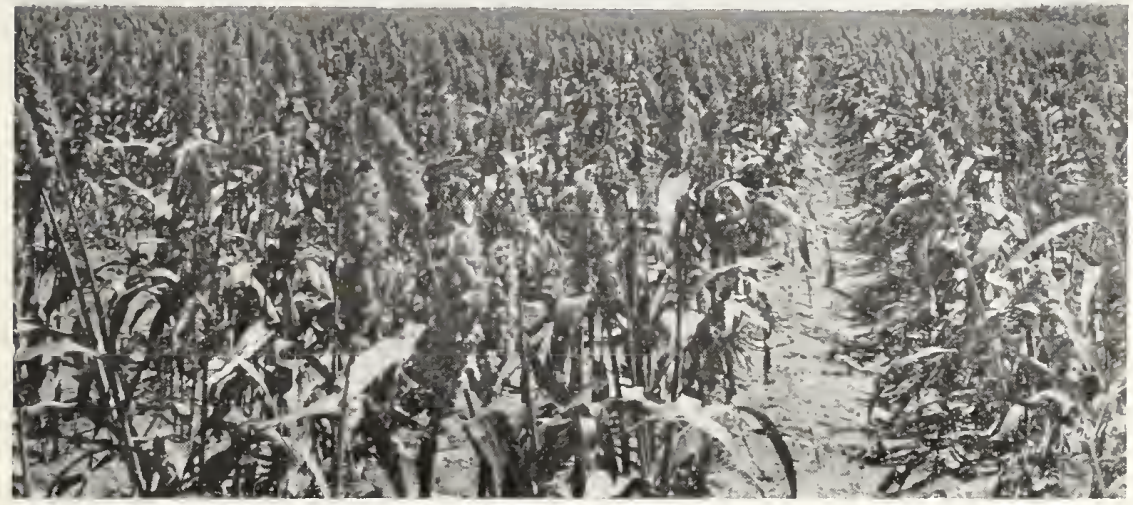

Hegari

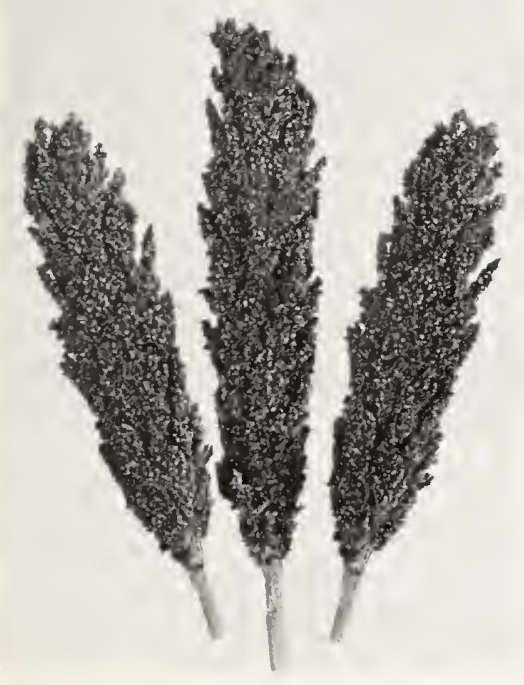

Grohoma

\section{Grohoma}

GROHOMA. Is the new grain sorghum of which you have read about the past two years. It is medium late in maturity; about four to five and half feet in height; has thick, leafy and dry but sweet stalk; large, loose, elongated, bushy heads and rather large brown kernels. The laves are very broad and wrinkled. In the past, this grain has been planted at the rate of only one pound to the acre. We suggest three to four pounds to the acre, in line with other similar grain sorghums. Lb., 25c; 2 lbs., 45c, postpaid. Not prepaid, lb., $15 \mathrm{c}$ : 20 lbs., $\$ 2.00$.
Nicholson's Selected Hegari

It makes an enormous yield of grain in most sections of the State and is more desirable for forage or silage than either Kafl or Feterita. It is dwarf in habit of growth, producing large heads of white grains that do not shatter. Plant 8 to 10 pounds per acre. From the demand we had it looks as if this is getting to be the most popular nonsaccharine Sorghum grown. Stands dry weather well. Lb. 20c; 2 lbs. $35 \mathrm{c}$, postpaid. Not prepaid, lb., 10c; 20 lbs., \$1.25. Ask for prices on larger quantities.

\section{Spur Feterita}

Spur Feterita is a distinct variety of Fet erita developed by the Texas Agricultural Experiment Station through breeding and selec tion. The stalk is from 6 to 12 inches shorter and 27 per cent heavier than common Fet erita. The stem presents a more stocky appearance, resembling Kafir, and carries from 14 to 16 leaves, which increase its forage value over common Feterita. This variety is more drouth resistant, the heads thresh out about 4 per cent more grain and the yield is several bushels higher than the common Feterita. Spur Feterita has proven superior to common Feterita in every section. It is well adapted to the black land region and in the western grain sorghum belt. The heavier stalk and the larger number of leaves make this variety valuable for forage and for silage. Lb., 20c: 2 lbs., 35c, postpaid. Not prepaid, lb., 10c; 20 lbs. \$1.25. Ask for prices on larger quantities. stalk usually tinged with red. Its straight stalk is sweet and juicy, showing by chemical analysis to contain 12.76 per cent saccharine in the juice, and analysis of the grain shows that the composition is very similar to that of Kafir. It matures earlier than Kafir, which fact has much to do with its drouth resistance. Darso makes excellent silage, and can be used as a grain, forage or silage crop. It has given splendid results in Texas. We recommend it highly. Lb., 20c: 2 lbs., 35c, postpaid. Not prepaid, lb., 10c; $20 \mathrm{lbs}$. \$1.00. Ask for prices on larger quantities.

\section{Milam County, Texas}

$I$ have used your DuBay seed disin. fectant, Ceresan on cotton and Semesan Jr. on corn, and had wonderful results with both. I think there will be lots of farmers use it next year around here. Yours truly,

WALTER HASSELMAN.

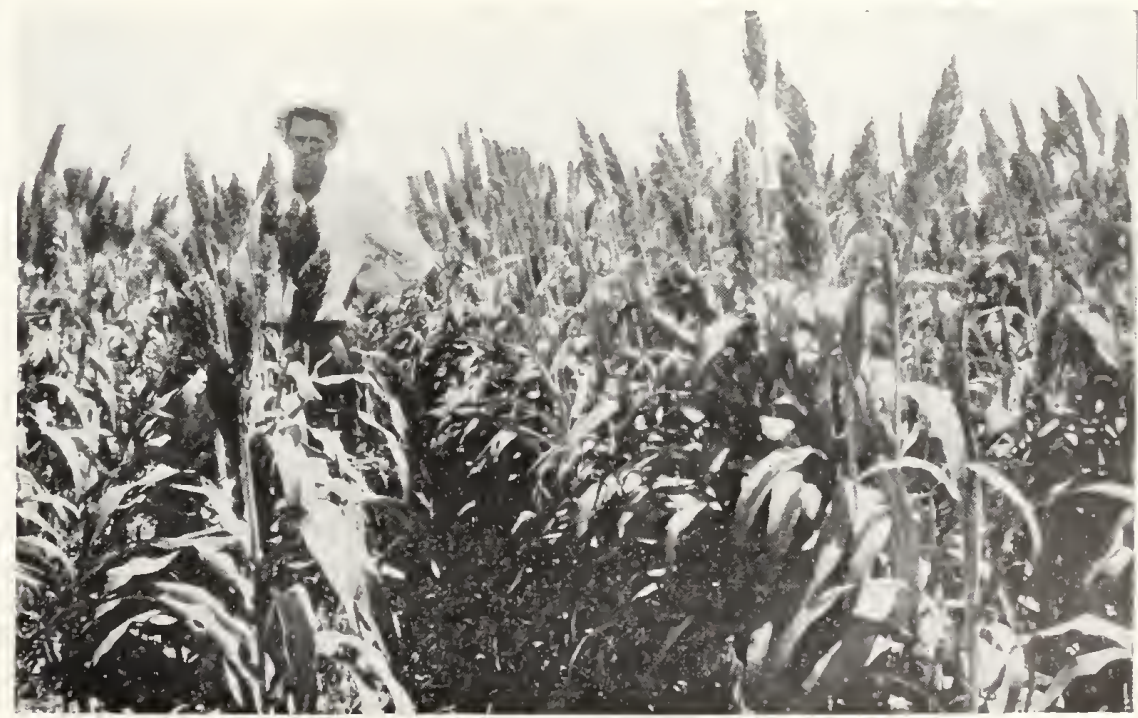

Darso 


\section{Robert Nicholson seed Co., Dallas, Texas.}

\section{Grain Sorghums}

\section{(Continued) \\ Nicholson's "Purity Brand" Fancy Double Dwarf \\ Yellow Milo

\begin{abstract}
This variety retains all the good qualities of its parent, the Dwarf Yellow Milo, and does not grow quite as tall Has immense heads, and the seeds are large. It is quick to mature, and may be planted late in the eason as a "catch-crop", and have plenty of ime to make before frost. When planted the early spring it will mature a crop early and after the heads are cut the stalk will branch out and produce additional cutharvesting much easier. Extra fancy seed, arge and bright. Lb., 20c; 2 lbs., 35e, postpaid. Not prepaid, lb., 10c; 20 lbs., \$1.25. Ask for prices on larger quantities.
\end{abstract} tings of heads. The compact stalk makes}

Fancy Dwarf Yellow Milo

It is becoming more popular every year, is very productive, and makes an enormous amount of the finest kind of grain relished by all kinds of stock. Sow in rows three feet apart, 5 to 10 pounds of seed per acre. lb., 10c; 20 lbs., \$1.00. Ask for prices on larger quantities.

\section{Algeria or Bishop Kafir}

A cross between Maize and Kafir. Livestock eat the entire stalk with relish. The stalk is sweet, containing a large amount of sugar, and grows from 4 to 5 feet tall, with leaves about twice the size of Indian Corn and from corn root, only it goes straight down instead of spreading, and will stand dry weather well, although it does exceptionally well in wet climates. The seeds are slightly larger than those of Maize, and are much softer. Heads are 12 to 18 inches long and usually each plant stooling out and making several heads. Use about five pounds of seed per acre, thinning out to a stand similar to corn. It should be allowed to stool before working too much dirt to the roots. Lb., 20c 2 lbs., 35c, postpaid. Not prepaid, $1 \mathrm{~b}$., 10c; 20 lbs., $\$ 1.25$. Ask for prices on larger quantities.

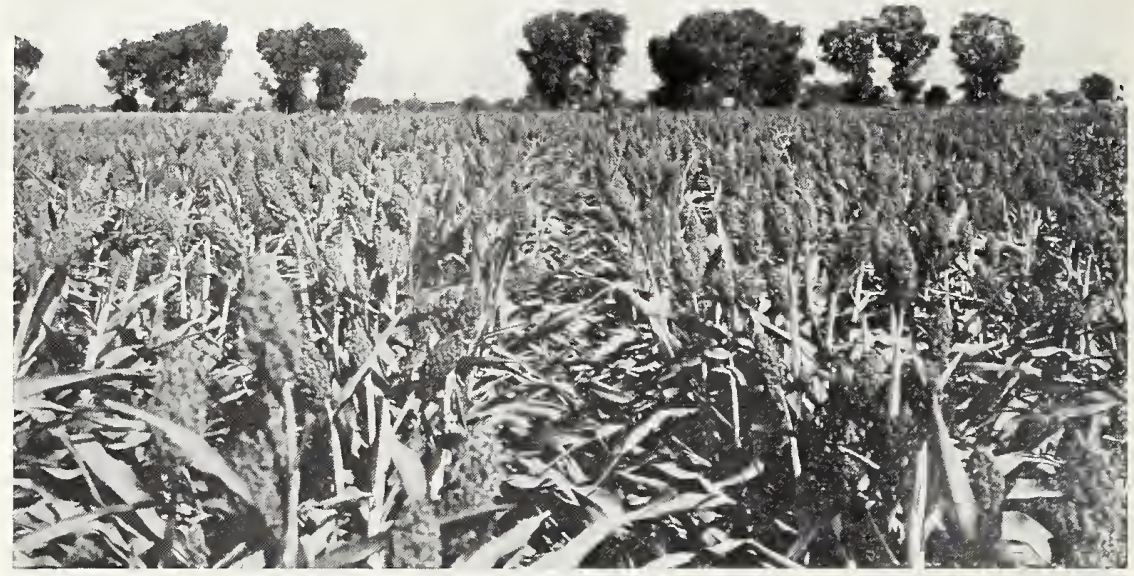

Double Dwarf Milo

\section{Shrock Kafir or Sagrain}

Fine for forage and ensilage, as it is quite sweet, and grows an abundance of broad, long leaves. It is a wonderful grain to stool out, not unusual for one seed to send up 6 to 10 stalks, each making a fine head of large, light brown grains, which make excellent stock and poultry feed. Drill at the rate of 3 to 5 pounds per acre. Lb., 20c; 2 lbs., 35c, postpaid. Not prepaid, lb., $10 \mathrm{c} ; 20 \mathrm{lbs} ., \$ 1.00$. Ask for prices on larger quantities.

\section{Shallu or Egyptian Wheat}

The grain grows something like Broom Corn. It stools out from the root, making from 3 to 6 stalks. It has been planted in almost every section of Texas and has produced splendid crops. It is very productive, making an enormous yield of grain and fodder. Shallu or Egyptian Wheat should be sown in drills three feet apart, using from 5 to 10 pounds of seed per acre. Lb. 20c 2 lbs., $35 c$, postpaid. Not prepaid, lb., 15c: 20 lbs. \$1.50. Ask for prices on larger quantities.

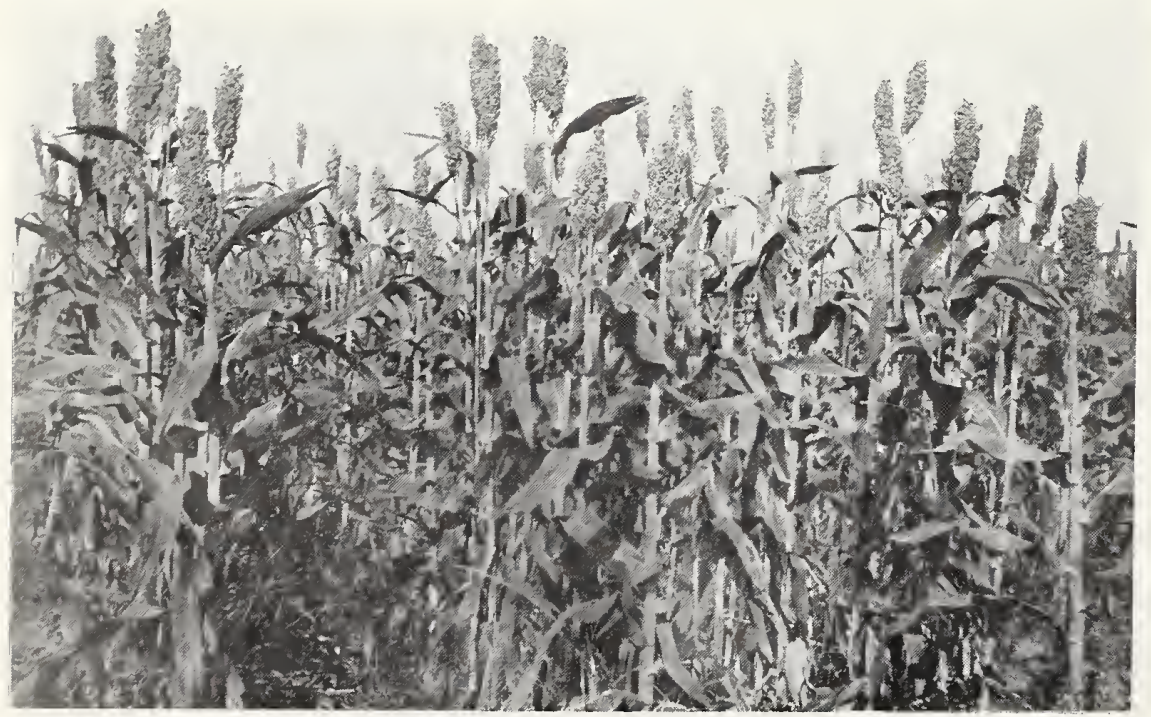

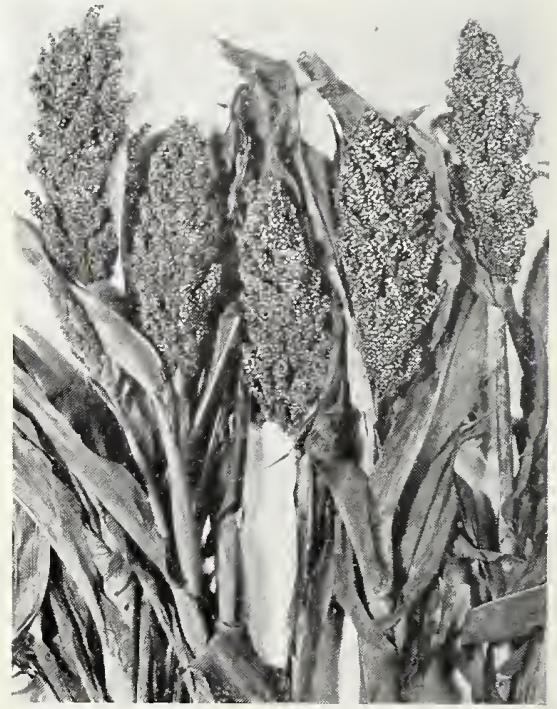

Algeria

\section{Black Hull White Kafir}

It grows from 4 to 5 feet high, making Itraight, upright growth, has a strong stem with enormous, wide leaves. The stalks keep green and are brittle, making an excellent fodder, either green or dried, for cattle and horses. The heads make the finest kind of feed. Sow in rows three feet apart, 5 to 10 pounds per acre. For fodder, sow one bushel per acre broadeast. Lb., 20c: 2 lbs., $35 \mathrm{c}$, postpaid. Not prepaid, lb., 10c; $20 \mathrm{lbs}$. $\$ 1.00$. Ask for prices on larger quantities.

Webb County, Texas

Just as an experiment, I tried some of yout Algeria seed down here in what is supposed to be a semi-arid country, and $I$ have made a wonderful crop of it. They say it will run around forty bushels pet acre.

Yours very truly,

(Signed) HAL D. WINSTON. 


\section{Tested Seeds for}

\section{Saccharine Sorghums}

Cane Seed for Syrup

These varieties are largely used for making syrup; they are also used to grow Cane for feed and ensilage. Sow in drills, using 5 to 10 pounds per acre

SUGAR DRIP. Extra large in size and in height and gives from 65 to 80 per cent of its weight in juice. For syrup it should be planted in drills, using from 5 to 8 pounds of seed per acre. Planted in drills for silage use from 8 to 12 pounds per acre. It may be sown broadcast for hay, using from 60 to 80 pounds per acre. Lb., 25c; 2 lbs., 45 c, postpaid. Not prepaid, lb., 15c; 20 lbs., $\$ 1.75$. Ask for prices in larger quantities.

CROOKNECK RIBBON. Planted principally to make syrup, yielding from three to four hundred gallons of the best syrup per acre. It is usually planted in rows $31 / 2$ feet apart, using from 5 to 10 pounds of seed per acre. Grows from 10 to 15 feet high. Texas Crookneck Ribbon Cane is one of th

\section{Cane Seed for Forage}

The following varieties are the best to use for forage. Sow 5 to 10 pounds per acre in drills or 100 to 150 pounds broadcast for hay.

EARLY AMBER. Largely used to sow for forage. Furnishes a large yield of most nutritious forage which can be fed either green or cured, and will yield two or three cuttings a year, stooling out thicker each time it is cut. Lb., 20c; 2 lbs., 35c, postpaid. Not prepaid, 20 Ibs., \$1.00. Ask for prices on larger quantities.

ORANGE. A later variety than the Amber and is used for forage and making syrup. Lb. 20c; 2 lbs., 35c, postpaid. Not prepaid, 20 can be grown to use as ensilage on account enormous yield. Lb., 25c; 2 lbs., 45c. postpaid. Not prepaid, lb., 15c; 20 lbs., $\$ 2.25$. Ask for prices on larger quantities.

JAPANESE SPRANGLED TOP OR HON JPRIP Matures in 125 to 158 days. The rrowth is very tall with many joints to the stalk, and necessarily a more vigorous root system, which produces a large quantity of Sorghum syrup to the acre, for the reason that the tonnage production is greater than that of any other variety. This is a favorite Cane where Sorghum production only is decired and when the rrowing season is suffciently long to mature it. Lb., 25c; 2 lbs. 45c, postpaid. Not prepaid, lb., 15c; 20 lbs. A larger quantitics.

lbs., \$1.00. Ask for prices on larger quanRED TOP SUMAC. Makes very fine fodder and is very extensively planted in Texas. Lb., 20c: 2 lbs., 35c, postpaid. Not prepaid. 20 lbs., \$1.00. Ask for prices on larger quantities.

NICHOLSON'S PURITY BRAND FANCY RED TOP SUMAC. This is our finest quality of Red Top Sumac Cane. Lb., 20c; 2 lbs. $35 c$, postpaid. Not prepaid, 20 lbs., \$1.25. Ask for prices on larger quantities.

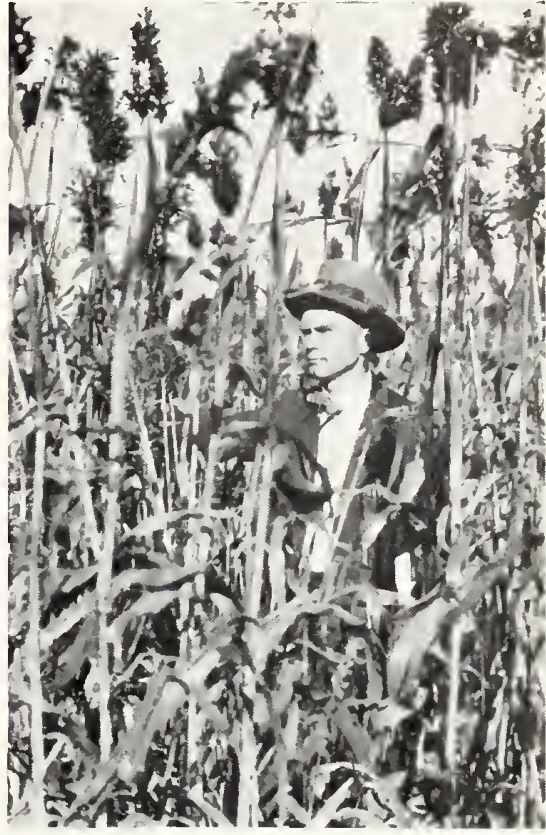

Early Amber Cane

\section{Nicholson's Tested Millet Seed}

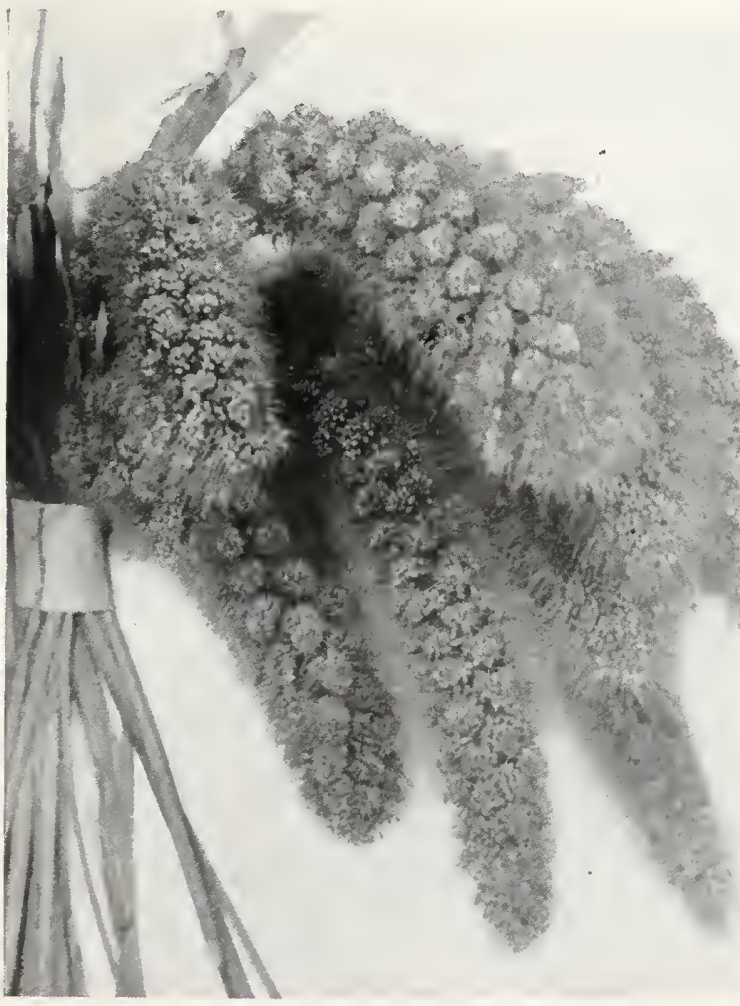

For a great many years we have made a specialty of Millet seed, recleaning it thoroughly with the latest and most improved machinery. Our Purity Brand Fancy Big Head German Millet is cultivated, Southern grown and is the very finest grade that we can buy. If you grow Millet for seed and want to produce large heads, you should sow about 5 to 10 pounds per acre in drills, and cultivate like a crop of corn. If planted for hay, sow at the rate of 20 to 25 pounds per acre, broadcast. Any reasonably good land will produce satisfactory crops of Millet Well drained upland is the best. Sow in April May and June.

NICHOLSON'S PURITY BRAND FANCY BIG GERMAN. This is the finest quality of Millet that we handle, and we have an enormous demand for it every year: numbers of our customers will plant no other kind; it makes the largest heads of any Millet we have ever seen grown. If you plant it once you will never plant any other kind. It grows very rank and is the best variety for hay or fodder. On good rich soil it will make a growth of 4 to 5 feet high, and hay is so tender that if cut at the right stage, which is when in full bloom, even the hogs will eat the cured hay greedily. A yield of five tons per acre is nothing unusual. Lb., 20c; 2 lbs., 35c, postpaid. Not prepaid, lb., 10c: 20 lbs., \$1.50. Ask for prices in larger quantities.

FANCY GERMAN. This is our second best grade of seed. Lb. $20 c ; 2$ lbs., 35c, postpaid. Not prepaid, Ib., 10c; 20 lbs., \$1.25. Ask for prices in larger quantities.

PEARL OR CATTAIL (Pencillaria). This makes a most nutritious and valuable continuous cutting forage plant. It will grow 10 to 12 feet high, but cutting can be commenced when it has attained height of 3 to 4 feet, when it will stool out enormously and make a rapid growth, and it can be cut this way three or four times in a season. Sow five pounds of seed per acre in drills three feet apart. or sow broadcast at the rate of twenty to thirty pounds per acre. Pearl or Cattail Millet should not be planted before May, Lb., 35c, postpaid. Not prepaid, lb., 25c; 10 lbs., $\$ 2.00$.

HOG OR MANITOBA. This variety grows much larger than th common kinds of Millet, and is valuable as poultry and stock food. Lb., 20c; 2 lbs., 35c, postpaid. Not prepaid, lb., 10c; 20 lbs., $\$ 1.25$ Write for prices in larger quantities.

\section{Milam County, Texas}

$I$ have used your DuBay seed disinfectant, Ceresan on cotton and Semesan Jr. on Corn, and had wonderful results with both. I think there will be lots of farmers use it next year around here.

Yours truly. 


\section{Robert Nicholson}

Seed Co., Dallas, Texas.

\section{Nicholson's Improved Seed Oats}

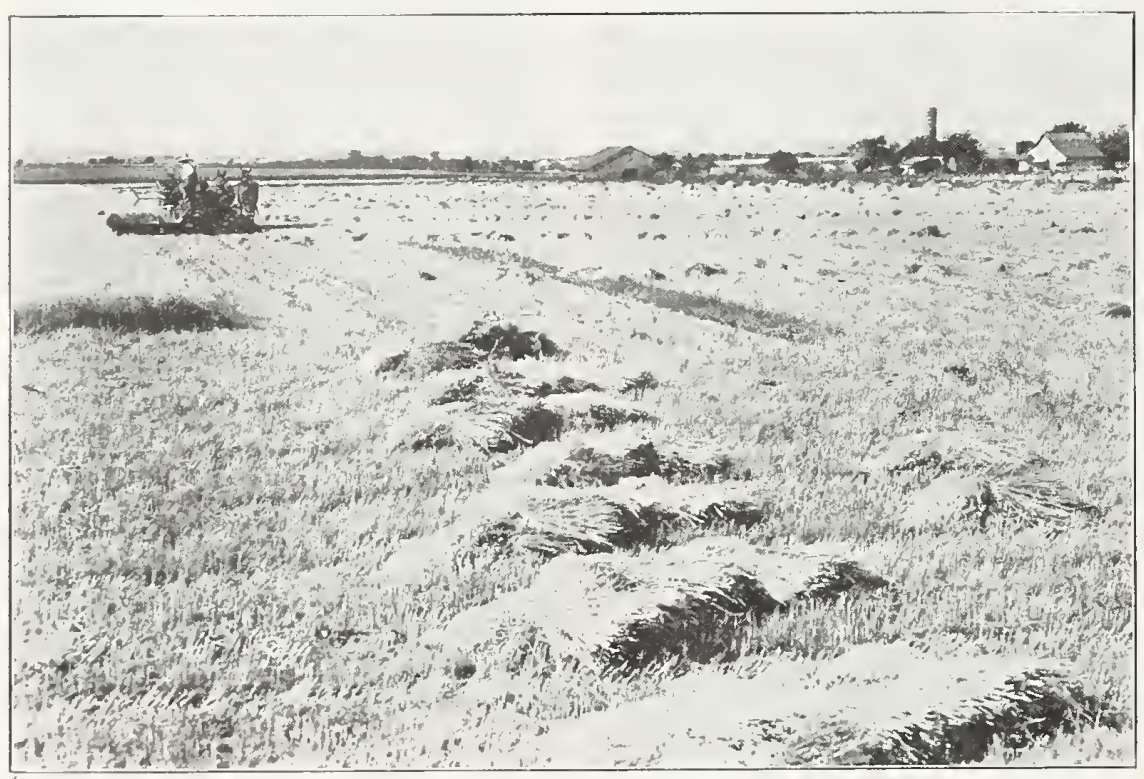

A Field of Nicholson's Extra Early Oats

TEXOTA BKAND FANCY RED RUST PROOF. We recommend these Oats to particular farmers who want a good quality of seed. We will be glad to submit samples. Bu., 60c; 10 bus, or over at $55 \mathrm{c}$ per bu., not prepaid. Write for prices on larger quantities.

NICHOLSON'S IMPROVED 100 BUSHEL RED RUST PROOF. This is an exceptionally fine strain of Red Rust-Proof Oats, that have been giving fine results in Texas. We have had our seed grown for several years by one of the best farmers in Dallas County. They have been yielding from 75 to 100 bushels per acre. We recommend them very highly. Bu., $65 \mathrm{c} ; 10$ bus. or over at $60 \mathrm{c}$ per bu., not prepaid. Write for prices on larger quantities.
NORTEX-Grown From Pedigreed Seed. This greatly improved red Oat was originated by the North Texas Experiment Station at Denton, Texas, and our seed was produced from seed direct from the station. It is of strong growth and matures about the same time as the old Texas Red Rust-Proof variety, but is heavier and more uniform. Bu., $75 \mathrm{c} ; 10$ bus. or over at $70 \mathrm{c}$ per bu., not prepaid. Please write for prices on larger quantities.
We exercise the greatest care in selecting and cleaning all of our seed stock, which we believe is equal to any that can be obtained. Sow Oats in spring or fall, using $2 \frac{1}{2}$ bushels per acre.

NICHOLSON'S FANCY FULGHUM OR KANOTA. This variety is very vigorous, $\mathrm{ma}$ turing about the same time as our Selected Extra Early, and is similar to that variety in habit of growth. The heads are shortbranched, and very erect. The kernels are a rich buff in color, and are usually free from beards. Very resistant to smut and also somewhat resistant to leaf rust. This is one of the best varieties of Oats, either for spring or fall planting, and is becoming more popular each year. Bu., 65e; 10 bus. or over at $60 \mathrm{c}$ per bu., not prepaid. Write for price. on larger quantities.

NICHOISON'S SELECTED EXTRA EARLY. Without doubt the best Oats grown in the South. These oats stand up well, mature about ten days to two weeks earlier than the ordinary Texas Red Oats, and ripen all at the same time. They grow about $31 / 2$ to 4 feet high, on good, stiff stems, do not blow down easily and are practically beard. less. No Oats we know of will compare with them in yield, general hardiness, resistance to heat and drouth, freedom from rust and other diseases. They make much better winter pasture than ordinary oats, as they have much broader blades. Everyone who knows will agree that earliness is one of the mosi essential features of the Southern Oat. Bu.. $65 \mathrm{c} ; 10$ bus. or over at $60 \mathrm{c}$ per bu., not prepaid. Write for prices on larger quantities.

PEDIGREED STRAIN RED RUST PROOF. 1118-69-Texas Red Rust-Proof Oats grown from pedigreed seed secured from the Denton Experiment Station. Bu., 75c; 10 bus., 70 per bu., not prepaid. Write for prices on larger quantities.

\section{Dwarf Essex Rape}

Rape is one of the most valuable forage plants, its many uses being considered, that has ever been introduced into the United States. The use of Rape has grown in a few years from a few thousand pounds of seed used, to thousands of tons of seed per year. Until lately Rape has been grown mostly for sheep pasture, but in recent years people have learned that it is equally valuable as a forage crop for cattle, hogs, and poultry. The young, tender leaves of Rape make fine greens for table use and are preferred by some to mustard and other greens. To those of our customers who are not familiar with Rape, we will say that it grows somewhat like a cabbage plant before the cabbage begins to head up; however, the Rape makes a larger plant, often 18 inches to 2 feet high, under favorable weather conditions and on good soil Rape will produce from 10 to 25 tons of green forage per acre. It can be grown in the fall as it stands our winters without killing: it can also be sown in the spring with good results. Sow in drills at the rate of 5 to 8 pounds per acre. Lb., 25c; 2 lbs., 45c, postpaid. Not prepaid, lb., $15 \mathrm{c} ; 20$ lbs., $\$ 1.75$. Ask for prices on larger quantities.

\section{Treat your Oats with Ceresan before sowing. For prices see page 66 .}

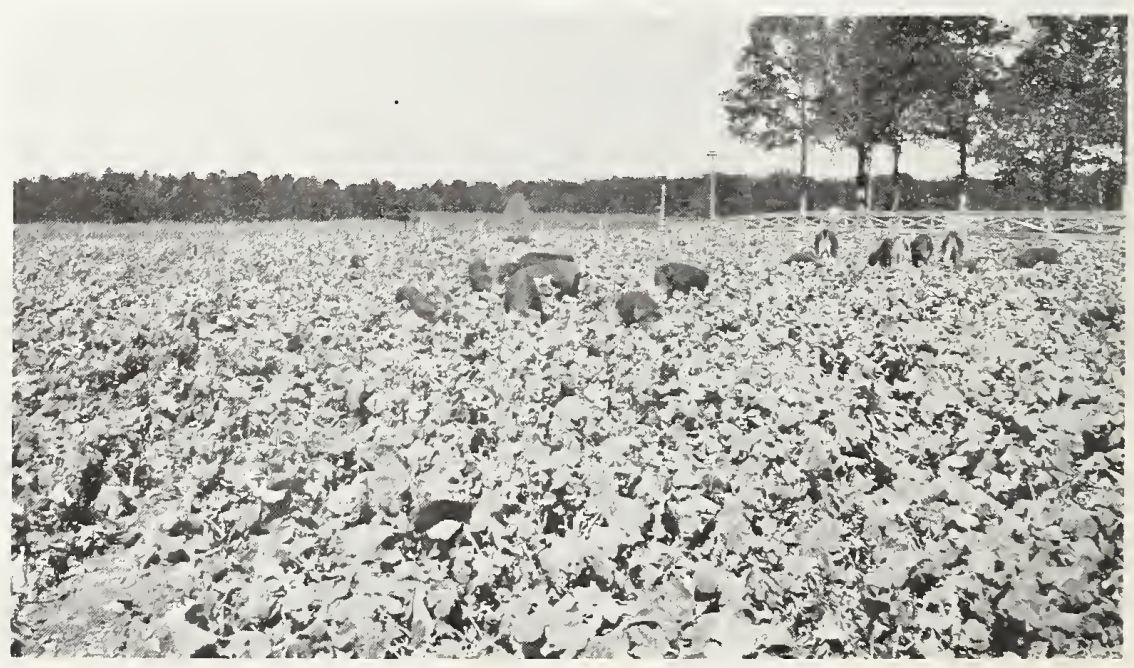

A Field of Dwarf Essex Rape 


\section{Tested Seeds for}

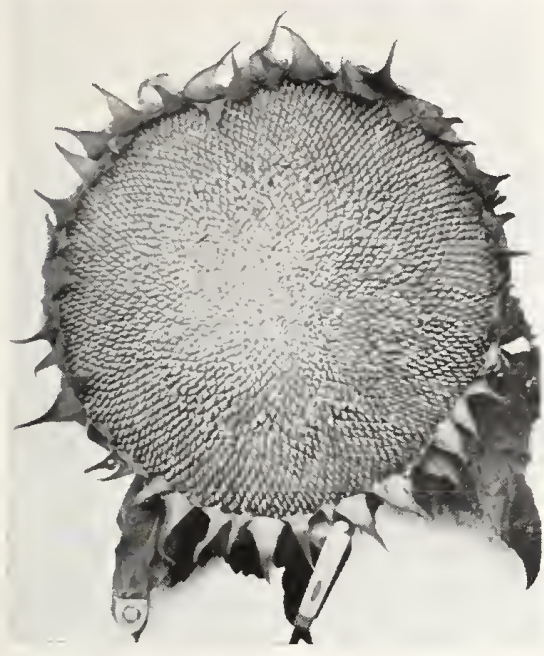

Mammoth Russian Sunflower

\section{Broom Corn}

SCARBOUGH DWARF. This type has much less seed on it, and is on the upper onethird of the brush, allowing much cleaner threshing and bales weigh fully one-third more and make the finest smooth parlor brooms, and also contain enough heavier, coarse brush for house brooms. We suggest planting 4 to 6 seeds in a hill with hills 30 to 36 inches apart, rows 40 inches apart. This plan allows better air circulation through the field and being in hills furnishes much better shade protection to the pulled heads as piled in large handfuls, heads up, on the north side of the standing hills. The best way to cure is to thresh same day as pulled and put in drying frames for a week, then bale carefully. Lb., 25c; 2 lbs., 45c, postpaid. Not prepaid, lb., 15c; 20 lbs., $\$ 2.00$. Ask for prices on larger quantities.

STANDARD EVERGREEN. Is very early and when properly planted and cultivated has beautiful green brush and commands the highest price. Harvested by cutting. Lb., 25c; 2 lbs., 45c, postpaid. Not prepaid, lb., 15c; 20 lbs., \$2.00. Ask for prices on larger quan. tities.

\section{Seed Wheat}

MEDITERRANEAN BEARDED. Pk., 35c: bu., $\$ 1.10 .10$ bus., $\$ 10.00$, not prepaid. Ask for prices on larger quantities.

\section{Mammoth Russian Sunflower}

The seed is highly valued by farmers and poultry breeders who have tried it. Single heads measure 12 to 20 inches in diameter, and contain large quantities of seed, and can be raised much cheaper than corn. This is a profitable crop for the farmer to grow, 29 there is a big demand for the seed to mix in poultry feeds. Five to ten pounds will in poultry feeds. Five to ten pounds will Not prepaid, lb., 20c; 10 lbs., $\$ 1.50$. Ask for prices on larger quantities.

\section{Peanuts}

For medium light, loamy or sandy soil, Peanuts are one of the most profitable crops. They yield very largely-yields of fifty bushela per acre being reported on land too poor to plant in corn. In addition to the yield of nuts, they yield quite largely of nutritious forage and produce ordinarily about a ton of excellent forage per acre in addition to the crop of nuts.

TENNESSEE LONG RED. A fine variety especially adapted to black, waxy land, $\varepsilon^{2}$ well as sandy soil. The nuts contain three large kernels each, and are enormously productive Lb., 30c; 2 lb. $55 \mathrm{c}$, postpaid. Not prepaid, lb., 20c; 20 ibs., \$2.50. Ask for prices on larger quantities.

IMPROVED VIRGINIA JUMBO, A very profitable sort planted almost exclusively by the Peanut-growing section of Virginia. It is the standard variety for roasting. Lb., $35 \mathrm{c}$ 2 lbs., $65 \mathrm{c}$, postpaid. Not prepaid, 1b., $20 \mathrm{c}$ 20 lbs., \$3.50. Ask for prices on larger quantities.

SPANISH. Spanish Peanuts grow in more compact form than the Virginia Peanuts, making it possible to grow them closer, which makes the cultivation easier. While the nuts are smaller, they are much sweeter and of finer flavor than the larger sorts and contain a higher per cent of oil than do the other varieties. The best crop in the South for fattening hogs. Lb., 25c; 2 lbs., 45c, postpaid. Not prepaid, 1 b., $15 \mathrm{c} ; 20$ lbs., $\$ 2.00$ Ask for prices on larger quantities.

\section{Rye}

Farmers, dairymen, and stock raisers are appreciating more the value of Rye as winter pasture crop. Sow at the rate of $11 / 4$ to $1 \frac{1}{2}$ bushels per acre.

FALL OR WINTER. Rye has long been recognized as one of our best grains for winter pasture. The seed we offer is all thoroughly recleaned and tested for germination. Pk., 30c; bu., $\$ 1.25 ; 10$ bus., $\$ 11.50$, not prepaid. Ask for prices on larger quantitics.

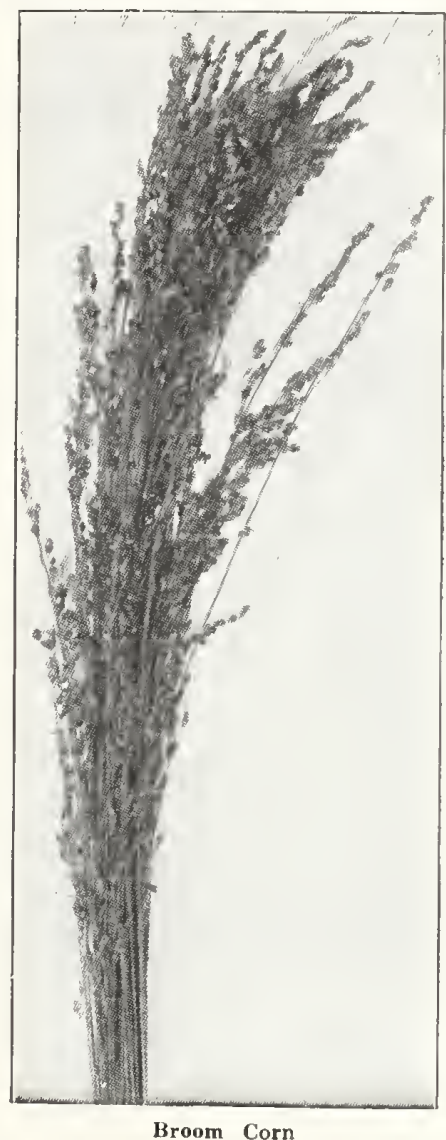

Nicholson's Bearded Barley

Treat your Barley with Ceresan before sow ing. For prices, see Page 66.

Makes excellent pasture and yields from 40 to 60 bushels per acre. We sell immense quantities of this splendid varjety each fall Barley should be planted at the rate of about two bushels per acre. Ground Barley make wonderful feed. Not prepaid, pk., 25c; bu. $80 \mathrm{c}$ : 10 bu., $\$ 7.50$. Ask for prices on larger quantities.

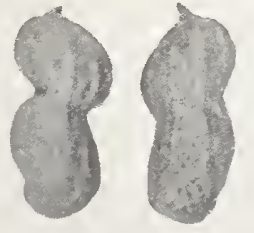

Spanish
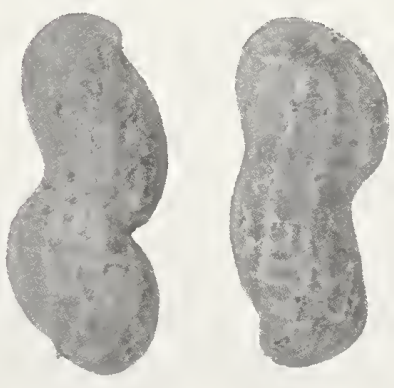
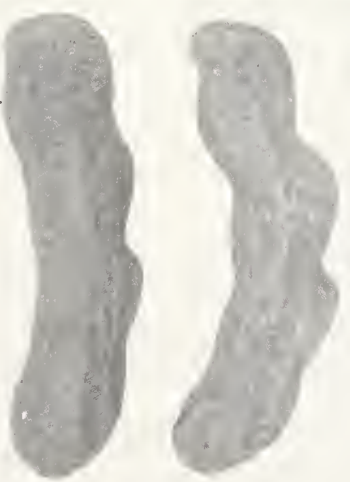


\section{Nicholson's Special Pasture Mixtures}

\section{For Different Sections}

Scientifically prepared mixtures of Grasses and Clovers adapted to growing with each other will, in most cases, give much better results than would be the case if one, or even two, plants were sown alone. The soil in the same fenced pasture may vary considerably in both quality and texture, and particularly in such cases a properly prepared mixture will demonstrate its superiority over any one or two plants sown alone. This, as well as other advantages, are to be gained, we find, in sowing different clovers and grasses in a mixture one serves as a nurse crop for the other, and they do better than when sown alone.

For several years past, we have had an enormous demand from customers all over Texas, as well as adjoining States, for mixtures of Grass and Clover seeds, suitable for permanent pastures.

We have given this matter a great deal of study and have also been in touch with the United States Department of Agriculture, our State Experiment Stations, County Agents, and also with many of our own good customers who have experimented in specific sections of the State and reported their results to us. We have also visited numerous pastures in different sections in order to get first-hand information direct from the parties who actually planted the seed.

With the above information, we now offer you the following prepared mixtures, carefully proportioned, for different sections of the State, which we believe will prove satisfactory to our customers.

The quantity of seed to be sown per acre varies according to the condition of the soil and the method and care used in planting. Measured in pounds, the quantities vary according to the size of the different seeds.

A firm seed bed that has been prepared a couple of months in advance and is thoroughly compact is highly important for such grasses as Dallis and Carpet. A short dry spell will kill the young seedlings in loose ground, such as is prepared for corn and cotton.

Breaking the land is not necessary, except where it has become badly baked or where the grass sod is so dense that the seed cannot well come in contact with the soil. In most cases, merely stir or scar the land with a disc harrow or scratcher, setting your machine for very shallow work.

Farmers often get the idea that they must have a good "loose" seed bed for grasses and clovers, just as they would for farm crops. This is not true. You must have a firm seed bed, or the small seedlings will die soon after sprouting. Lands that have had crops on them this season are well enough prepared.

Use a Seed Sower for even distribution of seed. See page 67 .

\section{No. 8 Pasture Mixture}

(For East Texas-Black Land)

Consists of the following Grasses and Clovers: Rescue Grass, Rye Grass,

Bermuda Grass, and

Dallis Grass

Sweet Clover

Black Medic Clover and

California Hulled Bur Clover.

Sow 25 pounds per acre.

Price, 10 lbs., $\$ 3.00 ; 20$ lbs., $\$ 5.60 ; 50$ lbs. $\$ 13.00 ; 100$ lbs., $\$ 25.00$.

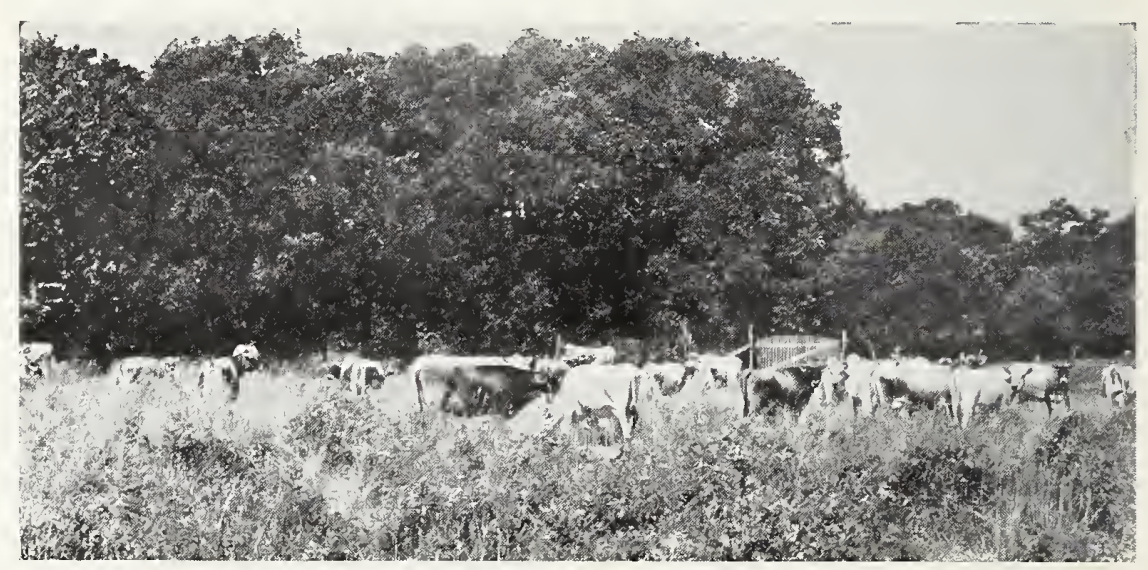

A Pasture Scene in Navarro County, Texas.

No. 9 Pasture Mixture

(For East Texas-Uplands)

Consists of the following Grasses and Clovers:

Bermuda Grass, Dallis Grass,

Rescue Grass, and

Rye Grass

Lespedeza

Black Medic and

California Hulled Bur Clover.

Sow 20 to 25 pounds per acre.

Price, 10 lbs., \$3.25; 20 lbs., \$6.00; 50 lbs., $\$ 14.00 ; 100$ lbs., $\$ 27.00$.

\section{No. 10 Pasture Mixture}

(For East Texas-Moist Lands)

Consists of the following Grasses and Clovers Carpet Grass

Rep Top Grass

Rye Grass

Dallis Grass

Lespedeza

White Dutch Clover and

Alsike Clover.

Sow 20 to 25 pounds per acre.

Price, 10 lbs., $\$ 4.00 ; 20$ lbs., $\$ 7.60 ; 50$ lbs., $\$ 18.00 ; 100$ lbs., $\$ 35.00$.

\section{No. 11 Pasture Mixture}

(For low bottom lands of the humid sections of Texas)

Consists of the following Grasses and Clovers : Bermuda Grass

Dallis Grass

Rye Grass

Lespedeza

White Dutch Clover and

Black Medic

Sow 20 to 25 pounds per acre.

Price, 10 lbs., \$3.25; 20 lbs., \$6.00; 50 lbs. $\$ 14.00 ; 100$ lbs., $\$ 27.00$.

\section{No, 12 Pasture Mixture}

(For the Gulf Coast section of Texas) Consists of the following Grasses and Clovers: Melilotus Indica

California Hulled Bur Clover

Lespedeza

White Dutch Clover

Dallis Grass

Rhodes Grass

Rescue and Rye Grass

Sow 20 to 25 pounds per acre

Price, 10 lbs., $\$ 3.90$; 20 lbs., \$7.50; 50 lbs., $\$ 17.50 ; 100$ lbs., $\$ 34.00$.
No. 13 Pasture Mixture

(For North and Central Texas)

Consists of the foilowing Grasses and Clovers: Rye Grass

Rescue Grass

Dallis Grass

Bermuda Grass

California Hulled Bur Clover

Sweet Clover

Black Medic and

Melilotus Indica.

Sow 20 to 25 pounds per acre.

Price, 10 lbs., $\$ 3.00 ; 20$ lbs., $\$ 5.60 ; 50$ lbs., $\$ 13.00 ; 100$ lbs., $\$ 25.00$.

\section{No. 14 Pasture Mixture}

(Uplands Sections of East Texas)

Consists of the following Grasses:

Rye Grass

Rescue Grass

Dallis Grass and

Bermuda Grass.

Sow 20 to 25 pounds or more per acre.

NOTE: This is a straight grass mixture without clovers. We suggest sowing Southern Spotted Bur Clover (in the bur) separately on the same land, as clover seed in the bur will not mix with the above grass seeds. Sow the grass mixture one way and the clover seed to cross it, as this will give you a better stand.

Price, 10 lbs., $\$ 3.50 ; 20$ lbs., $\$ 6.50 ; 50$ lbs., $\$ 15.00 ; 100$ lbs., $\$ 29.00$.

No. 15 Pasture Mixture

(For Fayette and adjoining Counties)

Consists of the following Grasses and Clovers: Dallis Grass

Rescue Grass

Melilotus Indica

California Hulled Bur Clover

Black Medic Clover

Kobe Lespedeza

Korean Lespedeza and

White Dutch Clover.

Sow 20 to 30 pounds or more per acre.

This mixture is strongly recommended for the above section, which is centrally located in the most extensive dairying section of Texas. Plant double the above amount for quicker results.

Price, 10 lbs., $\$ 4.50$; 20 lbs., $\$ 8.25$; 50 lbs.. $\$ 20.25 ; 100$ lbs., $\$ 38.50$.
IT PAYS to run a roller over your seed bed to firm the bed. This will assist greatly the germination of small grass seeds. 


\section{Grasses for Pastures and Lawns}

BULBOUS BLUE GRASS (Poa bulbosa) This is really a winter grass, as it dies out during the hot months, but revives at the first signs of cool weather. The seed in reality are very small bulbs about the size of a grain of wheat; they form without blossoming. This grass is used extensively in other sections with great success as a pasture grass. It will also make a good hay crop. Very good for hog as well as cattle pasture. Lb., \$1.10, postpaid. Not prepaid, lb., $\$ 1.00 ; 10$ lbs., $\$ 9.00$. Please write for prices in larger lots.

BIRD GRASS (Poa Trivialis). A splendid grass to sow under the shade of trees or in shady places where other grass does not do shady places where other grass does not do lawns or pastures. Lb., 75c; 2 lbs., \$1.40. postpaid. Not prepaid, lb., 60c; $10 \mathrm{lbs}, \$ 5.50$. Ask for prices on larger quantities.

IMPORTED CARPET GRASS (Axonopus Compressus). A perennial, spreading by creeping stems which root at every joint, thus forming a close, compact turf. Flourishes on land short in lime, thrives under grazing and trampling. Will stand more close grazing, trampling, and overflow than any pasture grass known. On barren desert or piney woods plains will produce a perpetual grazing ground. It is not a weed or a pest: plowing under will destroy it completely. The Government says in any Southern coastal plains or flat woods country this grass is better than Bermuda Grass. Grows 2 to $2 \frac{1}{2}$ feet high. Can also be used with good results on lawns, also golf courses. Would advise all of our customers to give this wonderful grass a thorough trial. Sow in September or October; also in February, March and April at the rate of 10 to 15 pounds per acre. For further information about Carpet Grass, write to the U. S. Department of Agriculture and ask for Farmers' Bulletin No. 1130 . Lb., 55c, postpaid. Not prepaid, lb., 45c; 10 lbs., \$4.00. Ask for prices on larger quantities.

CARPET GRASS (American grown). Description the same as the Imported seel. Lb. 40c; 2 lbs, 75c, postpaid. Not prepaid, 1b. $30 \mathrm{c}$ : 10 lbs., $\$ 2.50$.
CIIEWING'S OR RED FESCUE (Festuca

Rubra) Chewing's or Red Fescue Grass is used for both pasture and lawns. This grass seems to thrive on sandy or gravelly soil, where many other varieties fail. On account of the fine quality of turf which it produces, it is much used on golf courses, particularly o, if the soil is sandy.

The leaves are bright green and the plant does not grow in tufts, but creeps hy underround stems, so that one plant may eventually cover a circle two to four feet in diameter.

Plant at the rate of 30 pounds to the acre in Sentember, October or November. Lb. $75 c$, postpaid, Not prepaid, lb., 60c; 10 lbs. $\$ 5.50$. Please write for prices in larger lots.

DALLIS GRASS (Paspalum Dilatatum). Dallis Grass is a perennial, and is not a pest. It grows continuously, except in freezing weather, doing best where there is plenty of moisture, a smaller growth in proportion t the degree of dryness. While it does not grow in freezing weather, it comes ncarer growing all the year around than any other grass. Dallis Grass will gradually choke out Johnson Grass and other weeds, if grazed fairly close. It needs only a start, in order to stop washes and gullies. It is very easy to eradicate, one plowing will kill it out. In our trial grounds the past summer we found it stood the hot. dry summer better than any other grass.

The leaves are broad, a vivid green in color, and bunchy in growth. It makes a good pasture for all kinds of livestock and can be sown anywhere, at almost any time. It is a great labor saver. Dairy cows and other livestock attend to the harvesting of this grass and no plowing, hoeing or cultivating is required. It will grow on hilly, rough or washing land and puts them to beneficial use. We recommend that every farmer give Dallis Grass a thorough trial. Sow about 10 pounds per acre, or mixed with other grasses and clover, most any time in the year. We find imported seed germinates much better than American grown seed. Lb., 70c; 2 lbs. $\$ 1.30$, postpaid. Not prepaid, lb., 60c: $10 \mathrm{lbs}$. $\$ 5.00$. Ask for prices on larger quantiłies.

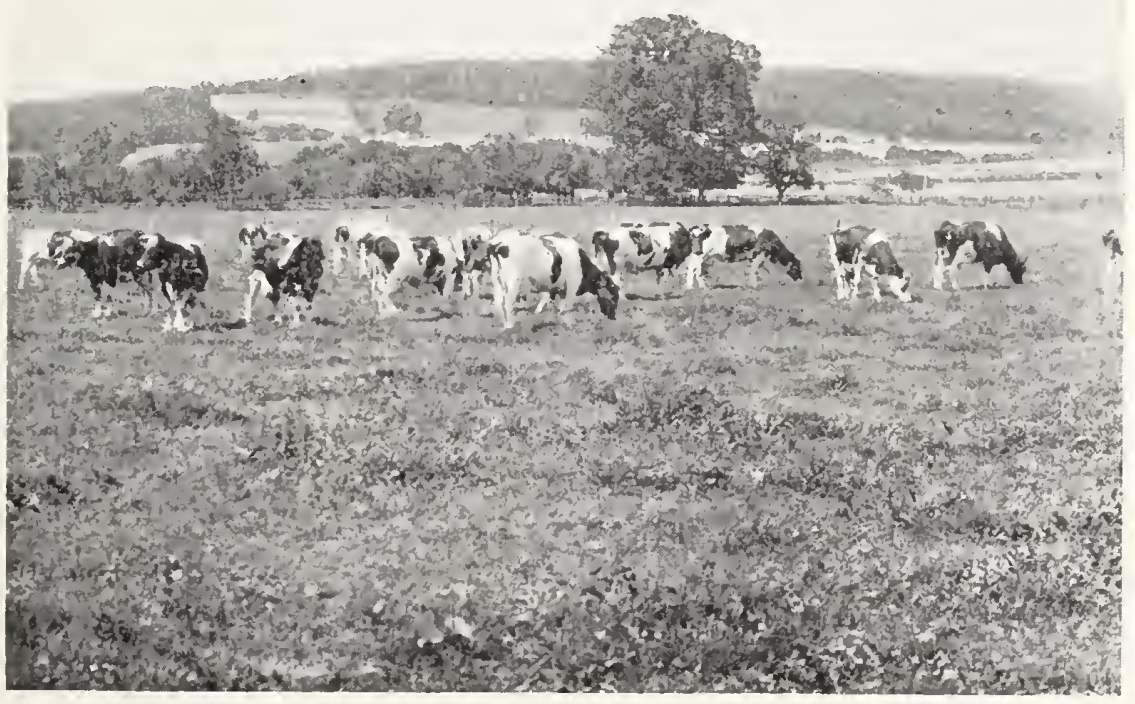

A Rich Grass Pasture Nets Wonderful Returns

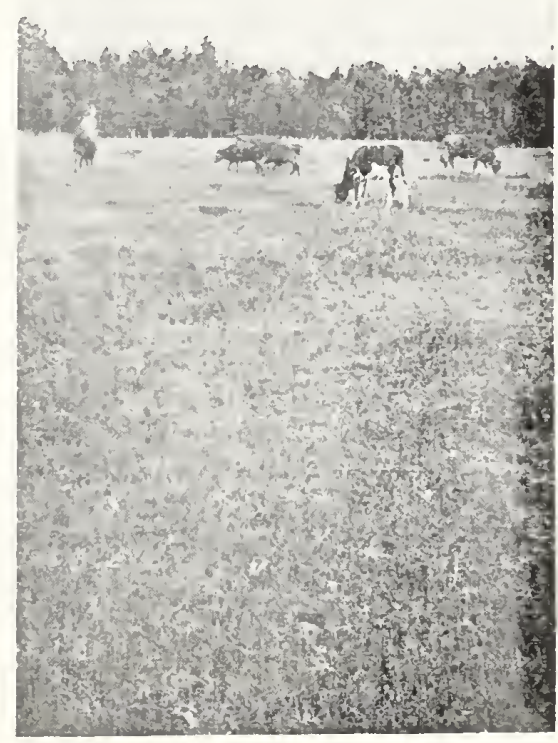

A Mixed Grass Pasture

JOHNSON GRASS (Sorghum halpense) Considered to be one of the finest grasses for hay in the South. The only objection is that it is difficult to eradicate. Lb., 25c; 2 lbs. $45 c$, postpaid. Not prepaid, lb., 15c; 20 lbs. \$2.25. Ask for prices on larger quantities.

KENTUCKY BLUEGRASS ( $\mathrm{Poa}$ Pratensis) Kentucky Bluegrass is not very popular in most sections of the South, but there is a demand for limited amounts for planting in sections where its worth has been proven. In many States it is used as the main lawn grass. We have seen reasonably good result in Texas where planted in the shade of large trees. Where it is adapted it makes a nice lawn when combined with Red Top Grass and White Dutch Clover. Kentucky Bluegrass is also used extensively as a pasture grass in the North.

One pound of seed will sow $10 \times 20$ feet, the equivalent of 200 square feet. Forty pounds per acre are required for nasture sowing. Sow in fall for best results. Lb., 40c; 2 lbs., 75c. postpaid. Not prepaid, lb., 30c; 10 lbs.. \$2.50. Ask for prices on larger quantities.

MESQUITE OR VELVET GRASS (Holcu Lanatus). An excellent grass to sow for both grazing and cutting for hay. It makes a strong growth of soft, broad leaves, about 8 to 12 inches long, and has no stalk or stem to make it coarse. Mesquite grass is a hardy, long-lived perennial and will with. stand continuous mowing or grazing. Under favorable conditions two or three cuttings may be obtained in a season. It is best to cut for hay when in full bloom, at which time the branches of the panicle are spread. ing: later they close up and become erect. We recommend the sowing of Mesquite Grass in mixtures, with other grasses or clovers in September or October; also in the early spring, at the rate of 20 to 25 pounds per
acre. Lb., 50c: 2 lbs., 90c, postpaid. No1 prepaid, lb., $40 \mathrm{c}$; 10 lbs., $\$ 3.20$. Ask for prices on larger quantities. 


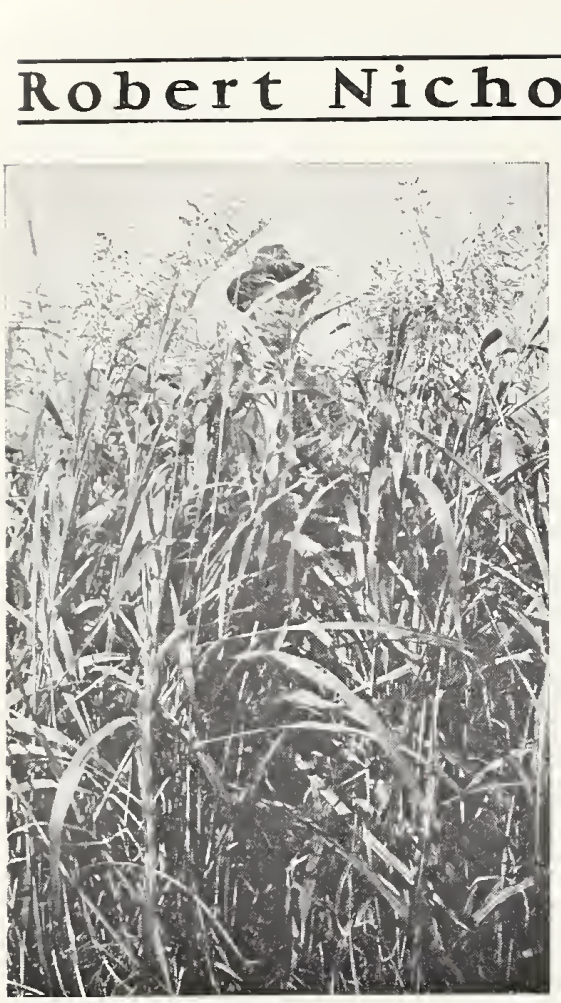

Sudan Grass

\section{Sudan Grass}

SUDAN GRASS (Sorghum vulgare sudanensis). Stands dry weather and does not blight under ample rainfall. It is an annual, the seed having to be sown every year. Like the sorghum crops it must be planted each spring, and dies when frost comes. The number of cuttings per season, therefore, depends on the length of the season. Usually matures in ninety days from first cutting. Its feeding value marks it as one of the dependable crops for every farmer. Stock of all kinds eat it readily and will leave other kinds of hay to eat it. Makes a splendid silage crop. In arid districts, it is usually planted in rows 36 inches apart. This requires five pounds of seed per acre. It is also sown broadcast where the rainfall is sufficient to produce corn. Sudan makes the highest yield and best quality of hay when sown broadcast, using from 25 to 50 pounds of seed per acre. Fancy seed, lb., 20c; 2 lbs., $35 \mathrm{c}$, postpaid. Not prepaid, lb., $10 \mathrm{c} ; 20 \mathrm{lbs}$., $\$ 1.25$. Ask for prices on larger quantities.

RED TOP GRASS (Agrostis Alba). Red Top is a fine grass for pasture, hay or lawn It is a perennial, with a creeping habit of growth which makes a coarse, loose turf. The leaves are about one-fourth of an inch wide with slender stems. This grass thrives best in low moist soil and will stand all kinds of wet weather or considerable drought on such soil. Will do well on soil so poor in lime that other grasses fail. It is often used for holding breaks to prevent erosion.

This grass is splendid for sowing on Bermuda lawns in the fall of the year; it will make you a beautiful green lawn throughout the winter months.

Sow the seed in September, October or November at the rate of 15 to 20 pounds United States Department of Agriculture Washington, D. C., for Farmers Bulletin No, 1254, which will give you more information on Red Top Grass. Found good in the South for winter golf greens. Lb., 40c; 2 lbs., 75c, postpaid. Not prepaid, lb., $30 \mathrm{c} ; 10$ lbs., $\$ 2.00$. Ask for prices on larger quantities.
IMPORTED RESCUE GRASS (Bromus Schraderi). Also called Prairie Grass, and is one of the most nutritious for permanent pasture grasses and does well in most soils, al though the best results will be secured from somewhat moist soil. It grows wild in various sections of Texas and is especially useful for winter and spring grazing, as it stays green all during the winter and spring. It dies down as soon as the weather gets warm. If allowed to reseed itself, it will come up again in the fall. September and October are the best months to sow, broadeasting the seed at the rate of 15 to 25 pounds per acre. It is also splendid to use in permanent pasture mixtures. The seeds are large, nearly equal to oats in size. Lb. 40c; 2 lbs., 75c, postpaid Not prepaid, lb, $30 \mathrm{c}$; 10 lbs., $\$ 2.75$ Please ask for prices on larger quantities.

RYE GRASS (Lolium Italicum). The seed we handle is American grown, of the Italian variety.

Of all the grasses for winter and spring pasture, we consider Rye Grass to be one of the best. Each plant, under favorable conditions, makes a round bunch with 20 or more shoots. Many varieties of Rye Grass are in use, but the American grown seed of the Italian variety is by far the best for the South. We find in our trials that it germinates better and produces stronger and more vigorous plants than the imported seed. It is exceptionally hardy, standing very cold weather, and stays green all durin

Rye Grass is an annual, and, if allowed to go to seed, will re-seed itself and come up again when the weather gets cool in the fall. It makes excellent grazing for all kinds of livestock and, if cut for hay, single cuttings will yield one to two tons of hay per acre. It grows from one and one-half to two and one-half feet high.

It is a wonderful grass to include in mixtures with other grasses and clovers for permanent pastures, this applying especially where you are starting a new pasture.

Rye Grass is used extensively to sow on Bermuda lawns in the fall, so as to have green lawns through the winter.

Plant in fall and early spring, at the rate of 35 to 40 pounds per acre, or about onequarter of this amount when planting with other grasses or clovers. Lb., 25c; 2 lbs., 45c, postpaid. Not prepaid, lb., 15c; $10 \mathrm{lbs}$. $\$ 1.25$. Ask for prices on larger quantities.
RHODES GRASS (Chloris Gayana). Rhodes Grass is a perennial hay and pasture crop. It is especially adapted to all sections of the South where the winter temperature does not go below 18. degrees. Colder than this it will probably winter-kill.

On good ground Rhodes Grass will grow over four feet high, with a fine, leafy stem, and it makes hay easy to cure and of the best quality. It can be cut from three to five times a season.

The grass spreads by runners on top of the ground. These runners may be six feet long, with joints every six inches or so, taking root and throwing up new plants. In this way it covers the ground rapidly. The frequent joints and the many crowns make it an ideal pasture crop. Broadcast 12 pounds of seed per acre, going over the field twice, sowing 6 pounds each way. Lb., 70c; 2 lbs., $\$ 1.35$, postpaid. Not prepaid, $1 \mathrm{~b}, 60 \mathrm{c} ; 10 \mathrm{lbs}$. \$5.50. Ask for prices on larger quantities.

\section{How to Plant Small Grass Seeds}

In planting Bermuda or other small grass seeds it is best to have the land thoroughly cultivated and pulverizel before planting. The seeds may then be scattered over the land by hand, or by using a small hand seeder, such as is listed in the back of this catalog. After sowing, a harrow or hand rake should be used, which will mix the seeds with the soil so they will be covered, then keep ground wet by frequent sprinkling, until the grass comes up to a sufficient stand, after which it may be necessary to irrigate a few times, if moisture is lacking, until the grass is large enough to take care of itself. In places where it is not convenient to sprinkle or irrigate, the planting should be done when there is a good season in the ground, and the land thoroughly rolled immediately after the final harrowing. This will pack the top soil so that there will be very little evaporation, and the moisture thus conserved will be ample to cause the seeds to germinate. We believe if you follow these directions carefully when planting small grass seeds you will have little or no trouble.

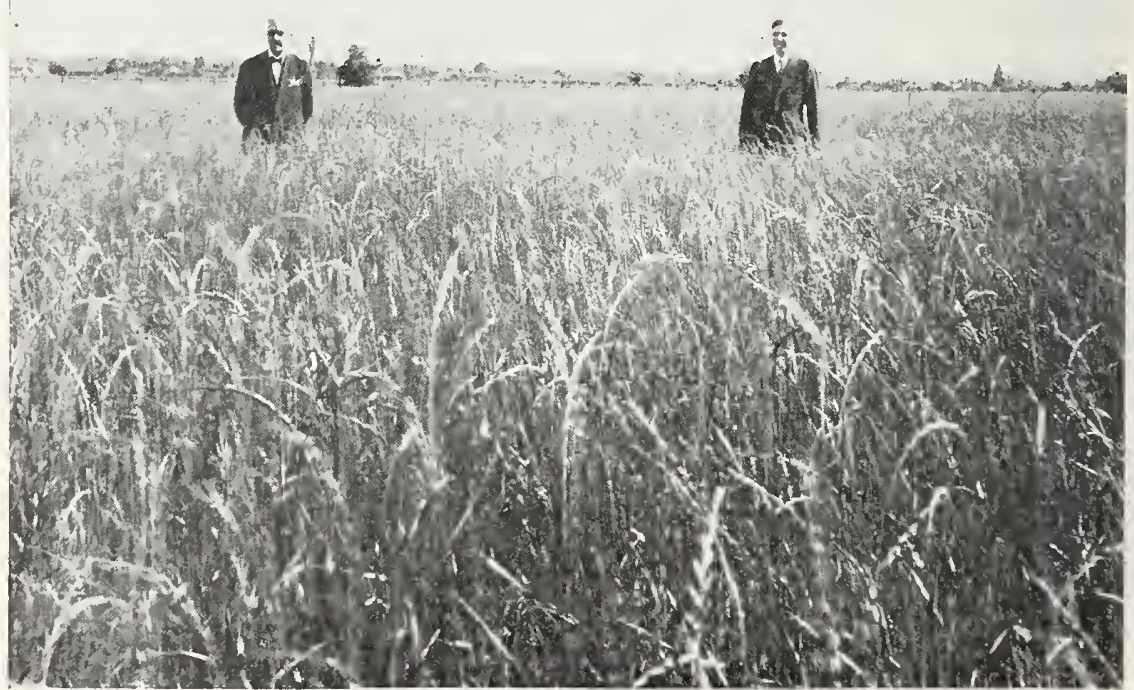

Nicholson's Rye Grass 


\section{Tested seeds for}

\section{Your Lawn--The Doorway to Your Home}

\section{Nicholson's Fancy Bermuda Grass Seed}

NICHOLSON'S FANCY BERMUDA GRASS SEED (Cynodon Dactylon). Will grow on almost any soil, makes splendid grazing as well as hay. Also is the finest grass to bow in the South for summer lawns. In order to have best success in the growing of Bermuda Grass the seed should be planted in the spring or late summer, when the weather is warm and moist. If sown before a wet spell the seed will come up in a very short time after rain. Have the ground well prepared, then sow the seed broadcast, at the rate of 10 to 15 pounds per acre. After sowing run a roller over the land so as to firm the surface, as Bermuda Grass requires a firm seed bed. Bermuda Grass is also splendid to use in connection with other grass and clovers for permanent pasture. In the fall, Red Top Grass or Rye Grass can be sown on the Bermuda Grass and in this way will produce green grass all winter, as these will take the place of the Bermuda. For lawns sow 5 to 10 pounds to every 1,000 square feet, 20x50, mixed with dry sand before sowing. Lb., 60c ; 2 lbs., $\$ 1.10$, postpaid. Not prepaid, lb., $50 \mathrm{c} ; 10 \mathrm{lbs} ., \$ 4.00$; 100 lbs., $\$ 30.00$. Ask for prices on larger quantities.

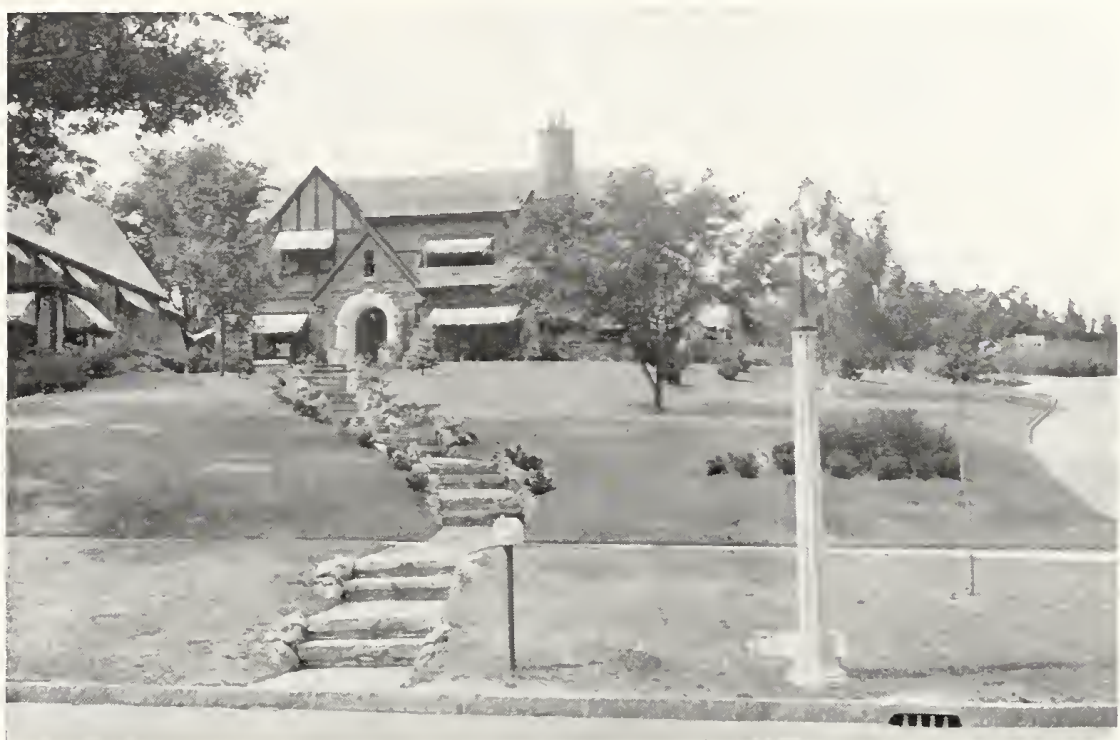

NICHOLSON'S MIXED SHADY LAWN GRASS. Especially prepared for shady places where Bermuda will not grow, such as spots under trees, etc. Before sowing, cut out as many of the surface roots of the trees as possible, as these sap the life of the soil. Loosen the top of the soil, then give it a top dressing of Nicholson's Pulverized and Sterilized Sheep Manure. Sow the grass seeds and rake them in lightly, keeping them well watered during the summer. One pound will sow $10 \times 20$ feet, the equivalent of 200 square feet of space. Lb., 80c; 2 lbs., $\$ 1.50$, postpaid. Not prepaid, $1 \mathrm{~b} ., 70 \mathrm{c} ; 10$ lbs., \$6.00. Please write for prices in large lots.

SEASIDE BENT (Agrostis maritima). An ideal grass for putting greens. Requires frequent cutting and top dressing. Very resistant to brown patch. More adapted to warm, humid conditions than other bents. Lb. $\$ 2.25$, postpaid. Not prepaid, $1 \mathrm{~b}$., $\$ 2.00 ; 10 \mathrm{lbs}$., $\$ 18.50$.

\section{A Pretty Lawn Greatly Improves Property}

NICHOLSON'S SPECIAL MIXED WINTER LAWN GRASS. This is a mixture of grasses that have proven the best sorts for winter lawns in the South. You can sow the seed on your Bermuda lawn or it can be just as successfully grown where there is no established lawn. Lb., 40c; 2 lbs., 75c, postpaid. Not prepaid, lb., 30c; $10 \mathrm{lbs}$, \$2.50. Ask for prices on larger quantities.

COLONIAL BENT (Agrostis tenuis). A variety of grass that is growing in popularity for golf greens. It requires consistent watering as well as clipping or mowing. A golf course in North Texas succeeded in keeping this grass green through the entire year. Plant in fall and spring. Lb., $\$ 1.50$, post paid. Not prepaid, $1 b ., \$ 1.35 ; 10$ lbs., \$12.50. Please write for prices in large lots.

\section{Nicholson's Evergreen Lawn Dressing}

\section{"The Wonder Fertilizer" Every Home Deserves a Good Lawn}

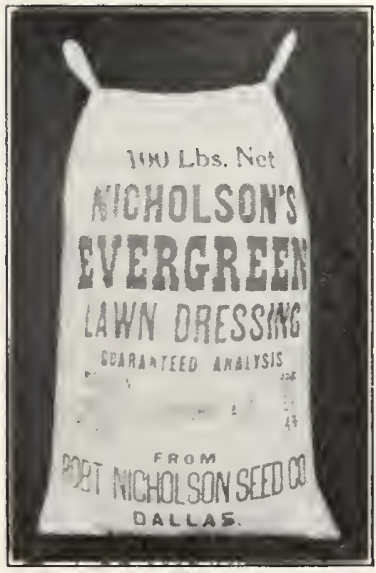

In fact, a beautiful lawn is one of the most attractive parts of your home. By using Nicholson's Evergreen Lawn Dressing, you can easily have a beautiful velvety green lawn all summer, until frost.

Nicholson's Evergreen Lawn Dressing is especially formulated for lawns and golf greens. It contains a high percentage of nitrogen that promotes a quick and heavy, rich green growth; also contains other plant food elements that give a substantial root growth or foundation.

If your lawn is built with a heavy root system which Nicholson's Evergreen Lawn Dressing will do, it makes it almost impossible for weeds to grow or infest your lawn. Ten pounds of Nicholson's Evergrcen Lawn Dressing contains more actual fertilizer value than 200 pounds of ordinary stable manure, and it has no noxious weeds or grass seed in it-no bad odors; is easy to apply and resembles sand in looks.

\section{WHEN TO APPLY NICHOLSON'S EVERGREEN}

The first application of Evergreen should be made in spring (April or May), then again, if necessary, in a month or six weeks.

\section{DIRECTIONS FOR USING}

Proper quantities to use: $100 \mathrm{lbs}$. to space $50 \times 100 \mathrm{ft}$; 50 lbs. to space $25 \times 100 \mathrm{ft}$. 25 lbs. to space $121 / 2 \times 100 \mathrm{ft}$.

On poor lawns, double quantities can be used with good results. The grass should be dry before applying the fertilizer, otherwise, if it is wet from rain or dew, the fertilizer will adhere to it and cause it to burn.

Nicholson's Evergreen Lawn Dressing is easy to apply by hand (it will not damage the skin), but care should be taken to apply it evenly. Do not try to cover too large an area at one time or you will have either started the application too heavily or too lightly. To insure even spreading we recommend that spaces about $10 \times 10$ feet or $4 \times 25$ feet be marked off by wooden stakes or stones, thus finishing your area as per measurements and amounts to use as stated above.

After applying Nicholson's Evergreen Lawn Dressing, a thorough sprinkling should be given to wash the tiny particles from blades of grass, down into the soil where they can do their work. 251 lbs., $\$ 1.75$; 50 lbs., $\$ 2.75 ; 100$ lbs., $\$ 5.00$, f. o. b. Dallas. 


\section{Use Fertilizer-Raise Bigger Crops}

SULPHATE OF AMMONIA. The most concentrated nitrogenous top dressing on the market. Contains Ammonia 251/4 per cent guaranteed. $\$ 5.00$ per 100 lbs., f. o. b. Dallas.

HIGH GRADE ACID PHOSPHATE. Our experience has taught us that nearly all Southern soils are lacking in available phosphoric acid thus making this fertilizer a very valuable one. 100-lb. sacks, $\$ 2.00$, f. o. b. Dallas.

NITRATE OF SODA. A fertilizer very quick in action and hastens the maturing of crops. It is most effective if applied during spring or fall at the beginning of the growing season. When applied in liquid form use 2 ounces to 1 gallon of water or 100 to $150 \mathrm{lbs}$. per acre (leaflets furnished free). Lb. $10 \mathrm{c} ; 100$ Ibs., $\$ 5.00$, f. o. b. Dallas.

HIGH GRADE RAW BONE MEAL. An excellent dressing for field and garden crops and lawns. For rose and flower beds, use 1 part to 50 parts of soil. $10 \mathrm{lbs}$., $75 \mathrm{c} ; 100-\mathrm{lb}$. sacks, $\$ 5.00$, f. o. b. Dallas.

POTASH. $\$ 5.00$ per 100 lbs., f. o. b. Dallas.

STIM-U-LANT. This is the finest fertilizer we have ever handled foll directions as to how to use are printed on each package. 20c, 30c and $80 \mathrm{c}$ per package, postpaid.

LIME (Hydrated). For sweetening and renovating soil that has become sour. 40-lb. bag, 60c, f. o. b. Dallas.

TOBACCO STEMS (Ground). A combined fertilizer and insecticide. Contains four very important elements of fertilizer-Nitrogen, Phosphoric Acid, Potash and Humus or decayed organic matter.

On old lawns apply Tobacco Stems in the fall of the year. It gives the grass necessary plant food and provides protection during the winter months.

On new lawns, the ground stems should be worked into the soil before seeding or used as a mulch fertilizer after seeding. Ground Tobacco Stems are a natural insecticide, containing a high percentage of nicotine, which kills many kinds of insects, grubs and worms. Price, 25 lbs., $\$ 1.35$; 50 lbs., $\$ 2.50 ; 100$ lbs., $\$ 4.75$, f. 0. b. Dallas.

\section{Nicholson's All Round Fertilizer}

NICHOLSON'S ALL ROUND FERTILIZER. Is scientifically prepared and is the best balanced plant food for all plant life, such as flowers, vegetables, shrubs, trees, lawns and field crops. Instructions for use in each package. $10 \mathrm{lbs}$. 50c; 25 lbs., $\$ 1.00 ; 50 \mathrm{lbs} ., \$ 1.75$; 100 lbs., $\$ 3.00$, f. o. b. Dallas.

Write us for free leaflet on this wonderful fertilizer.

ADCO converts straw, corn stalks, dry leaves and garden refuse, Ach as leaves, stalks, cuttings, potato, bean and pea vines, etc., into such as leaves, stalks, cuttings, potato, which, when mixed with almost Artificial Manure. ADCO is a powder which, when mixed with a most mass into real manure fully equal to the farmyard product in fertilizmas intor, but free from foul odor, flies, weed-seeds, etc. The process is perfectly simple and not at all laborious. Gardeners should not cesait for their refuse to accumulate. Add one pound of ADCO (a wait for their refuse to accumulate. Add one po to every four cubic pound baking-powder can is a convenient measure) to every four cubic refuse as it comes along, treating it the same way, and by the end of the summer it makes a rich, inoffensive manure heap.

ADCO, in 25-1b. bags-F. O. B. Dallas

(Enough for 12 wheelbarrow loads of garden waste, making one-half ton of manure).

ADCO, in 100-lb. bags (4 25's) - F. O. B. Dallas............... (Enough for a heap $6 \times 6 \times 6$ ft., ma
two tons of manure).

ADCO, in 150-1b. bags-F. O. B. Dallas. (Enough for a heap 10x10x6 ft., making about. three tons of manure).

$\$ 3.00$

$\$ 10.00$

$\$ 12.50$

\section{Lawn Sprinklers}

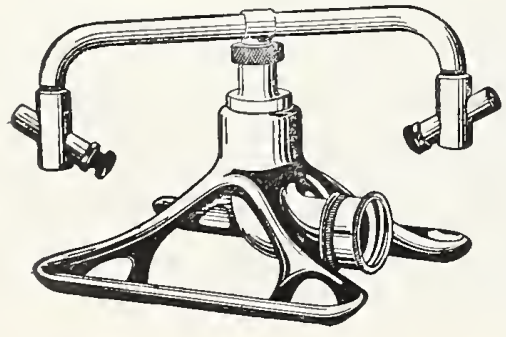

WHIRLING SHOWERS. Is a variable and adjustable lawn sprinkler. The nozzles are adjustable for both volume of spray and distance and will allow a coverage of from 10 to 70 feet in diameter. All brass except malleable iron base. This is one of the best sprinklers made. Price, $\$ 2.50$ each, postpaid.

\section{Peat Moss}

PEAT MOSS-Nature's Soil Improver. A fine granulated Peat Moss. It is a valuable soil improver for all horticultural and agricultural purposes.

Peat Moss improves the physical structure of the soil. It absorbs ten times its weiglit in water, or more, conserving it, releasing it for the plants in periods of drought.

Peat Moss makes soils favorable to beneficial soil bacteria, necessary to good vegetative growth. Plants consume hurnus and so do the bacteria in their operation of transforming air nitrogen into valuable plant food. Peat Moss tends to increase the humus content of the soil.

Peat Moss consists chiefly of decomposed vegetable or organic matter. It is free from weed seeds and detrimental fungi. It is produced from high-level moorland, consisting chiefly of sphagnum moss of high quality, light in color and weight. It is light and has superior moisture absorbing and retaining qualities.

Peat Moss is clean, odorless, easily stored and handled. It promotes root development, resulting in strong, robust plants.

Sead sown in soil mixed with Peat Moss germinates more quickly than seeds in soil alone.

Peat Moss is available to use in hotbeds and cold frames; also to work in the soil of your flower beds, vegetable garden, around trees. shrubs and hedges. It helps to hold the moisture and keep the soil from packing. It is also just the thing to use to top dress beds of bulbs after they have been planted. By giving rose beds a tor dressing of about two inches of Peat Moss during the summer, it keeps the beds from drying out. It is fine to use on lawns. It is also fine to use for storing roots of dahlias, tuberoses, gladiolus, and other bulbs during the winter.

Peat Moss is clean, has no disagreeable odor and is free from weed seeds. Large bales usually contain 20 bushels. Large bales, price $\$ 4.00$ each.

Ask for Descriptive Circulars and prices in larger quantities.

\section{Nicholson's Sheep Manure}

Sheep Manure Will Make Your Plants Grow to Perfection.

Nicholson's Sheep Manure is a concentrated pulverized and sterilized natural manure, conveniently packed in bags. This natural, weedless plant food builds up your soil and gives Nature just what it needs to make the plants grow to perfection.

LAWNS. Produces a thick, velvety green turf of lasting beauty. You can't grow a lawn unless your soil is rich and fertile. Broadcast 200 pounds to every 2000 square feet of lawn area.

GARDENS. Stimulates healthy green foliage and a profusion of vividly colored flowers.

VEGETABLES. Produces a big crop of crisp, tender vegetables.

FRUIT. Very effective fertilizer for small fruits and orchard crops Improves color, size and quality.

Price, 5 lbs., 50c; 10 lbs., 75c, postpaid. Not prepaid, 5 lbs. 30c: 10 lbs., 50c; 50 lbs., $\$ 1.50 ; 100$ lbs., $\$ 2.75$. Ask for prices in larger quantities.

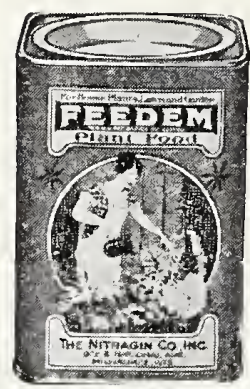

FEEDEM-Plant Food. For house plants. lawn and garden-for vigorous growth. A well balanced food (fertilizer) for potted plants, sweet peas, roses, begonias, ferns, cut flowers, shrubs, lawn and garden-all plant life. Provides just the nourishment needed for vigorous growth, heavy foliage, brilliant colors; a wonderful tonic for sick plants.

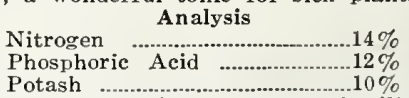

Note high analysis. Buy plant fertilizer by analysis-not price or size of package.

Sold in neat, convenient cans. 4 ozs., $30 \mathrm{c}$ : 8 ozs., 50c. When buying plant fertilizer compare analysis-not price or size of package.

\section{Adjustable Rain Drop Sprinkler}

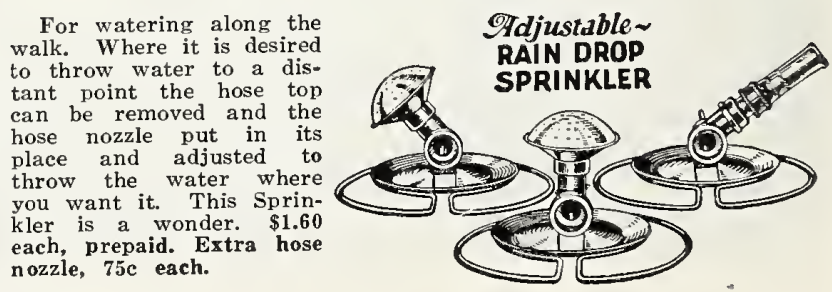




\section{Tested Seeds for (}

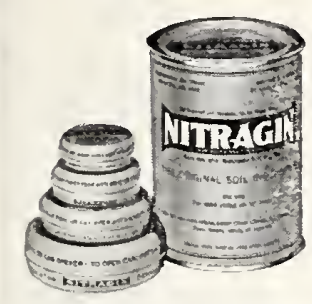

NITRAGIN is prepared as pure culture, then mixed with black soil-like substance, and packed in ventilated tins: many convenient sizes.

LEGUME GERMS ARE PERISHABLE.

The December first Expiration Date on every N1TRAGIN can protects you against undated inoculators, which may be old and worthless. NITRAGIN guaranteed fresh each year.

MIXING NITRAGIN WITH SEED.

Legume germs die rapidly when dried. NITRAGIN containing between $30 \%$ and $40 \%$ moisture, will readily stick to seed without adding water, and give good inoculation. However, for best results, the preferred practice, recommended by the Nitragin Company and Agricultural authorities, is to use water when mixing legume culture with seed. Directions on every NITRAGIN can.

\section{INOCULATE ALL LEGUMES}

WITH

\author{
Alfalfa \\ All Clovers \\ Soy Beans \\ Cow Peas
}

FRESH EACH YEAR-EVERY CAN OF NITRAGIN PACKED WITH BILLIONS OF FRESH, EFFICIENT LEGUME GERMS

Prices on Nitragin are f. o. b. Dallas.

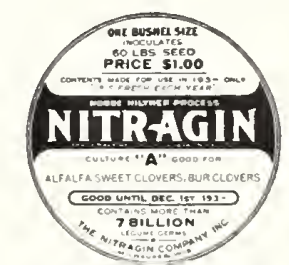

Legumes that are worth planting are worth inoculating.

\section{PRICES :}

NITRAGIY-A. For Alfalfa, all Sweet and Bur Clovers, 1/4-bu. size, $40 \mathrm{c}$ : $1 / 2$-bu. size, $60 \mathrm{c} ; 1$-bu. size, $\$ 1.00 ; 5$-bu. size, $\$ 4.75$.

NITRAGIN-B, For all other Clovers except Lespedeza. 1/4-bu. size $40 \mathrm{c}: 1 /$-bu. size. $60 \mathrm{c} ; 1$-bu. size $\$ 1.00: 5$-bu. size, $\$ 4.75$

NITRAGIN-C. For Peas (except Cow Peas). Vetches and Lina Beans, 1/2-bu. size, 40c; 1-bu. size, 60c; 100-lb. size, 90c; $31 / 2$-bu size, $\$ 1.80 ; 5$-bu. size, $\$ 2.50$.

NITRAGIN-D. For all Beans (except Lima, Soy and Velvet). 1/2-bu size, $40 \mathrm{c}$; 1 -bu. size, $60 \mathrm{c} ; 100$-lb. size, $90 \mathrm{c} ; 31 / 2-\mathrm{bu}$, size, $\$ 1.80 ; 5$-bu size, $\$ 2.50$.

NiTRAGIN-E. For Cow Peas Velvet Beans, Lespedeza and Peanuts. 1-bu, size, $40 c$; 2-bu, size, $70 c$; 5-bu, size, $\$ 1.50 ; 10$-bu, size, $\$ 2.50$.

NITRAG1N-S. For Soy Beans, 1-bu. size, 10c; 2-bu. size, 70c; 5-bu size, $\$ 1.50 ; 10$-bu. size, $\$ 2.50$.

GARDEN NiTRAGIN. For Garden Peas, Garden Beans and Swee Peas. 25c cach.

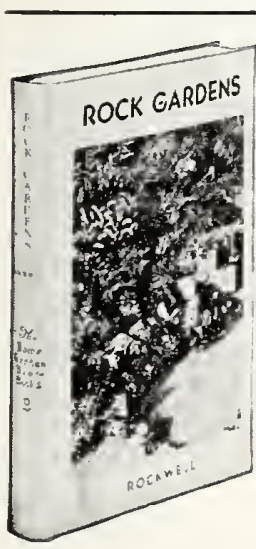

\section{BOOKS FOR BETTER GARDENS}

IRISES. (Rockwell). A wonderful guide which will bring you success with Irises, Describes the different varieties fully; tells the best soils and different locations for maximum results. 80 pages with 54 illustrations. $\$ 1.00$.

LAWNS. (Rockwell). Shows how to start a lawn right and how to keep it smooth and velvety thereafter. Suggestions on laying out the lawn, grading, fertilizing, planting, care, weeds, etc. 87 pages, 39 illustrations. $\$ 1.00$.

GLAD1OLUS. (Rockwell). Recommended as the best brief guide on gladiolus growing. 45 illustrations, 79 pages. $\$ 1.00$.

ROCK GARDENS. (Rockwell). Shows just how you can build a rock garden yourself, large or small, and at little expense. Tells what to plant, ete. 31 illustrations, 86 pages. $\$ 1.00$. HOW TO GROW ROSES. (Pyle, McFarland, Stevens). Full and practical information on rose growing. 138 illustrations, many in natural color. 211 pages. $\$ 2.00$.

LANDSCAP1NG THE HOME GROUNDS. (Ramsey). Shows just how to develop your home grounds for greatest beauty. 175 illustrations and plans; 170 pages. $\$ 2.00$

HOME FLOWER GROWING. (Volz). It will teach you how to propagate and cultivate your plants. Fertilizer, care, ete. 151 illustrations 364 pages. $\$ 3.50$.

GARDENING IN THE LOWER SOUTH. (Hume). Complete garden guide for the South. Covers flowers, fruits, vegetables, shade trees, etc. This book is a popular seller in Texas 102 illustrations, 472 pages. $\$ 5.00$.

DAHLIAS. (Rockwell), 65 illustrations, 80 pages. $\$ 1.00$

PECAN GROWING. (Stuckey and Kyle). 49 illustrations, 233 pages. $\$ 3.00$.

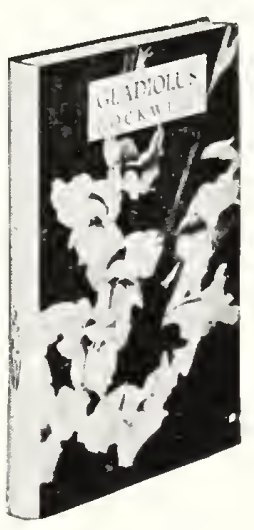

Listed at Postpaid Prices.

\section{Rain-Spray Sprinklers}

This new Diamond Rain-Spray Sprinkler is going to prove to be a wonder with both small and large home owners. It doesn't even have to be coupled and uncoupled. Each spray-head is regulated with a small thumb kcrew. It can be taken apart, cleaned and put together again in two minutes. The Rain-Spray device is completely rustproof. The metal support is sherardized before it is painted. Each length of hose with its sprayers constitute a portable spraying system, easily movable from place to place. It is possible to sprinkle more thoroughly and possible to sprinkle more thoroughly and
evenly than with the most extensive underground system. A length of hose equipped with five Rain-Sprays uses no more water than a single nozzle turned on full. Yet each spray head, with the average city pressure, will cover a radius of ten feet. When desired, the spray heads can be screwed down so that the length of hose may be used with a nozzle, in the same manner as an ordinary bose. Please realize that the Rain-Spray Sprinkler is priced just slightly higher than ordinary garden hose of the same quality. It is a product of the Diamond Rubber Company. Price: $25 \mathrm{ft}$. section with 3 sprayers, \$3.50; $50 \mathrm{ft}$. section with 5 sprayers, $\$ 6.50$, f. o. b. Dallas.
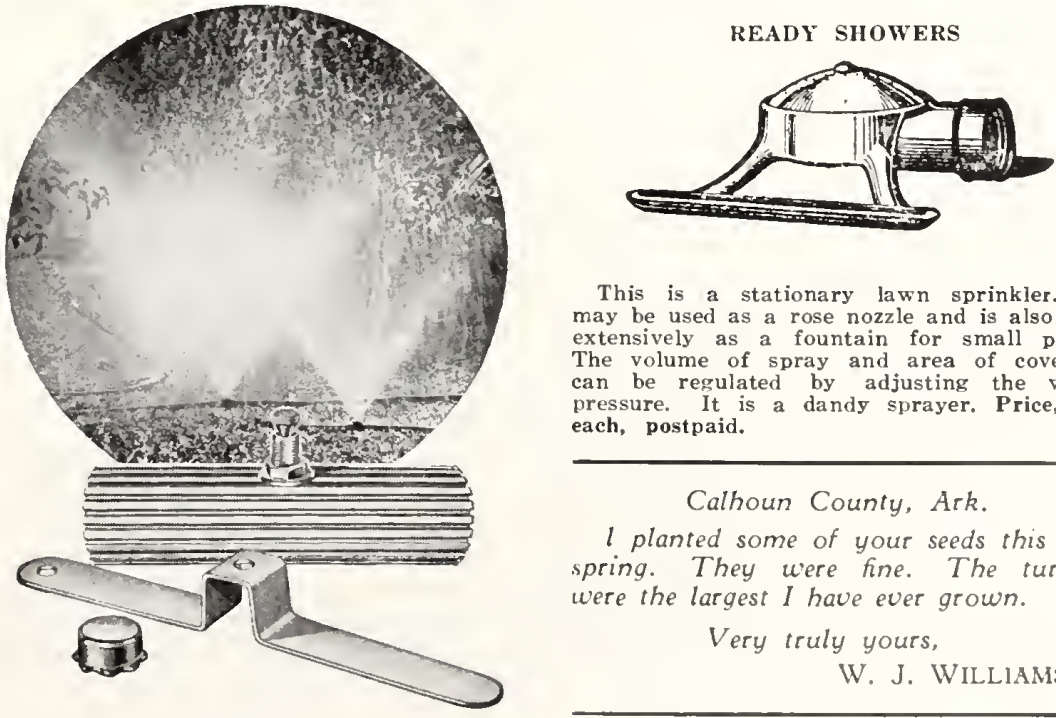

This is a stationary lawn sprinkler. It may be used as a rose nozzle and is also used extensively as a fountain for small ponds. The volume of spray and area of coverage can be regulated by adjusting the water pressure. It is a dandy sprayer. Price, 75e each, postpaid.

\section{Calhoun County, Ark}

$l$ planted some of your seeds this past spring. They were fine. The turnips were the largest I have ever grown.

Very truly yours,

W. J. WILLIAMS. 


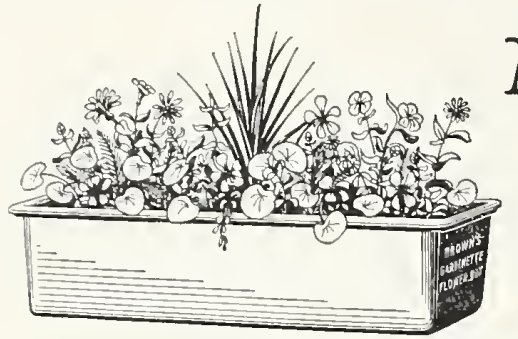

Miscellaneous Supplies

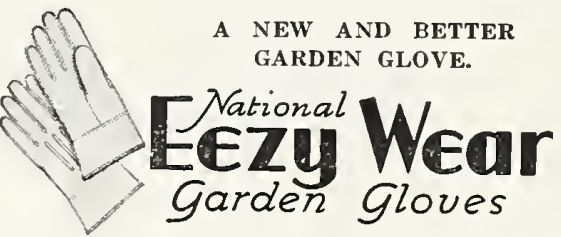

Made from special imported hides processed to render them amazingly soft and pliable. Permit almost barehand freedom, yet provide complete all-leather protection. Ideal for garden and similar uses.

\section{Dirt-proof, Durable, Washable}

Four sizes: "Small" and "Medium" for women, "Medium" and "Large" size for men. Price, $75 \mathrm{c}$ a pair: 2 pairs for $\$ 1.40$. This is the first time we have ever offered an allleather garden glove with these special qualities at such a low price.

Please add $10 \mathrm{c}$ if wanted by parcel post.

\section{MULCH PAPER}

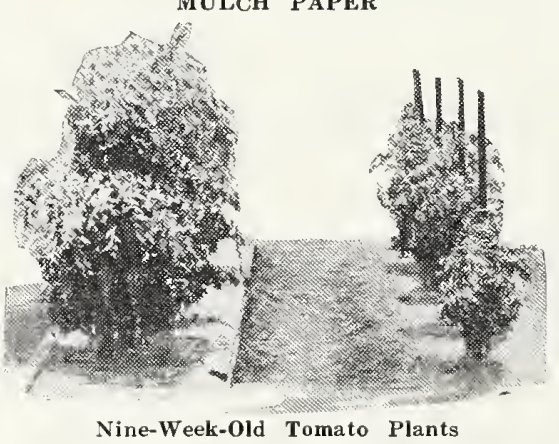

One at left grown under mulch paper.

CEDAR PLANT TUBS. This tub by far is the neatest, cheapest and best plant tub ever offered. Made of cedar, painted green, bound with electric welded hoops. Just the tub for large or small specimen plants of all kinds. We offer the following four sizes. The two larger sizes are supplied with drop handles.

\begin{tabular}{|c|c|c|c|}
\hline & & & $\begin{array}{l}\text { Each } \\
\$ 3.50\end{array}$ \\
\hline $\begin{array}{l}\text { No. } \\
\text { No. }\end{array}$ & $\begin{array}{l}30 . \\
40 .\end{array}$ & $\begin{array}{l}16 \text {-inch } \\
14 \text {-inch }\end{array}$ & ................ $\$ 30$ \\
\hline No. & 50. & 12 -inch & $\ldots 2.25$ \\
\hline & 60. & $\begin{array}{l}\text { 10-inch } \\
\text { Prices }\end{array}$ & f. o. b. Dallas \\
\hline
\end{tabular}

DODSON SPARROW TRAPS. The most successful device ever invented to rid your place of the most persistent pest that we ever brought upon ourselves. This trap will positively rid your place of sparrows. Is made of very heavy tinned wire with all joints elec. trically welded. Trap is in continuous operation and requires no setting or baiting. Size $12 \times 18 \times 36$ inches. $\$ 10.00$ f. o. b. Dallas.

STANDARD FLOWER POTS. Standard Flower Pots and Fern Pots. 3-inch, 3c; 4inch, $5 c$; 5-inch, $7 c ; 6$-inch, 10c; 8 -inch, 20c 10 -inch $50 \mathrm{c}$, and 12 -inch, $80 \mathrm{c}$, not prepaid.
Bigger, Better, Earlier Crops with GATOR HIDE MULCH PAPER. Do away with the labor of weeding-make one acre produce what you got from two or three acres last year. Get your crops in from one to three weeks earlier than your neighbor. Gator Hide is a tough, durable paper impregnated with a special asphalt. Unrolled under plant beds, it imprisons all moisure in the soil. Its black surface catches and retains the sun's heat, raises the soil's temperature, checks cooling at night. Gator Hide comes in two types, both in $18^{\prime \prime}$ and $36^{\prime \prime}$ rolls.

Type A for Annuals in field culture: $18^{\prime \prime}$ roll (1350 sq. ft.) ....................................\$3.00 $36^{\prime \prime}$ roll (2700. sq. ft.) ................................. 6.00

Type $B$ for Perennials and ALL garden work :

$18^{\prime \prime}$ roll (45 ft. long) ................................... .65

$18^{\prime \prime}$ roll (675 sq. ft.) .................................. 3.00

$36^{\prime \prime}$ roll (1350 sq. ft.) .................................. 6.00

Special prices for larger quantities.

Ask for booklet "Miracle of Mulch Paper".

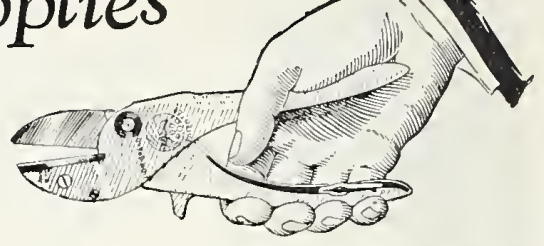

"ROLCUT" SHEAR. A shear which cuts smoothly and without effort. No other shear like it. Blade and other parts can be replaced. Postpaid, per pair, $\$ 3.00$.

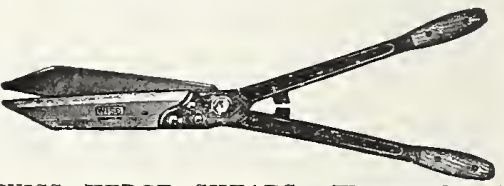

WISS HEDGE SHEARS. Wonderful cutters. Take the ache out of hedge cutting. One edge serrated and one knife edge. Forged steel handles. Tempered steel blades, substantial $7 / 16$ in. bolt with nut and lock washer. Gunmetal finish. Nickel plated blades, size $61 / 2$ in., $\$ 2.75 ; 8$ in., $\$ 3.25 ; 9$ in., $\$ 3.50$, f. o. b. Dallas.

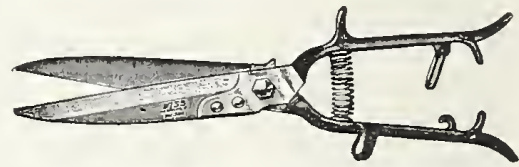

WISS GRASS SHEARS. For clipping grass along the edges of flower beds, walks etc The handles fit the hand comfortably. The blades are of tempered cutlery steel. $\$ 1.50$ each, f. o. b. Dallas.

PRUNING SHEARS. Used for all kinds of light pruning and trimming, made of highest grade of steel. Heavy 10 -inch, $\$ 2.00$; light 8-inch, \$1.00, not prepaid.

BULL DOG TREE PRUNERS. These are as strong and powerful as any pruner made. Handles about 20 inches long. $\$ 3.50$ each. not prepaid.

\section{Cel-O-Glass}

CEL-O-GLASS. Is a new, unbreakable glass. It is the most economical and practical glazing material on the market. It replaces ordinary, fragile, costly glass in nearly every instance. It is made of coarse mesh galvanized wire cloth treated in such a manner that the spaces between the strands are filled with a clear, transparent, tough, flexible substance that will not rub off, peel or become brittle. Cel-0-Glass sheds rain hail, sleet. It is unaffected by extreme cold, and will stand over $400^{\circ}$ Fahrenheit and cannot rust. You can trim it with ordinary scissors to fit any space. A hammer and staples are the only tools necessary to put it up. It is very much lighter in weight than glass, one foot weighing only one-tenth of a pound. Cel-O-Glass is used in the following ways. Hotbed and cold frame sash, plant protectors, partitions, color screens, lamp shades, etc. By using Cel-O-Glass there will be no more broken glass in the above-mentioned uses. $15 \mathrm{c}$ per square foot, f. o. b. Dallas.

\section{PEAT MOSS POULTRY LITTER}

Just the thing for Baby Chicks. Peat Moss Poultry Litter will keep the floors of your chicken quarters dry and clean and prevent the spread of such harmful baby-chick diseases as coccidiosis and white diarrhoea.

Poultry Litter will keep the house absolutely dry and keep the birds in fine, healthy condition.

Peat Moss is more economical than any other form of litter, both in actual cost of material and in saving of labor in cleaning and renewing. Makes the chicks more comfortable and happier than any other form of litter and it reduces loss by fire. Is a powerful absorbent, as it readily takes up from ten to fifteen times its own weight in moisture. Moreover, Peat Moss is a wondurful insulator and will prevent the harmful effects that cold floors have on your birds. Large bales, price, \$4.00 each, f. o. b. Dallas. Send for descriptive matter.

\section{Poultry Supplies}

We carry a complete line of Poultry Tinware, such as Fountains, Feeders, Hoppers, Oat Sprouters, Brood Coops, Electric Incubators and Brooders. Write for a copy of our descriptive booklet with prices on the above items. 
Conkey's Poultry Remedies

Known All Over the World-The Peultry man's Standby. Keep a Few Select Remedies

Always at Hand Ready for Emergency.

CONKEY'S OLD RELIABLE POWDER

(Formerly Conkey's Roup Remedy)

This famous treatment has been on the market for thirty years, known to poultrymen everywhere as Conkey's Roup Remedy. Easily given in the drinking water letting the birds belp themselves. In mild doses it acts as a tonic. Pkgs., 30c; 55c; \$1.10, postpaid.

CONKEY'S BALMO

(Formerly called Conkey's Canker Special) A soothing cooling application for relieving irritation around the swollen eyes and head and in the mouth. Package, 55c, postpaid. CONKEY'S SALVO

(Formerly called Sorehead Remedy)

Good to have on hand for treating sores,

cuts and wounds of any description.

Pkgs., 30c, 55c, postpaid.

CONKEY'S DIATEX

(Formerly called Conkey's White Diarrhea Remedy)

Once you have used this old reliable preparation you will never be without it. Play safe-keep this remedy in the drinking water of all baby chicks.

Pkgs., 30c, 55c, \$1.10, postpaid.

CONKEY'S POULTRY WORM REMEDY (For Large Round Worms)

Over 90 per cent of market poultry are infested with worms, of which there are many varieties-Round Worms, Gizzard and Caecal Worms and Flukes or Leaf Worms. Worms cause great loss and flocks should be treated regularly.

Pkgs., 30c, 55c, postpaid.

CONKEY'S Y.o. For Poultry and Live Stock. Contains Cod Liver Oil, Yeast, Soy Bean Oil Meal, Wheat Middlings, Red Oxide of Iron. 1-lb., 55c: 2 lbs., $\$ 1.00 ; 5$ lbs., $\$ 2.00$ Prices f. o. b. Dallas.

CONKEY'S HEAD LICE OIN'TMENT For overcoming and preventing the murderous head louse.

Pkgs., 15c, 30c, postpaid.

\section{CONKEY'S SCALY LEG REMEDY}

An excellent application for removing this unslightly condition. Package, 30c, postpaid.

CONKEY LICE POWDER

(Contains Sodium Flouride)

For dusting hens, nests, growing chicks and for use wherever body lice must be overcome. Pkgs., 25c, 40c, 85c, prepaid. Pails, 12 Ibs., $\$ 2.60 ; 25$ Ibs., $\$ 5.00$, not prepaid.

Conkey's Mite Liquid, Nox-i-cide and Fly

Knocker weigh packed for shipment as fol-

lows: Pint 3 lbs., quart 4 lbs., half gallon

6 Ibs., gallon $10 \mathrm{lbs}$., five gallons $47 \mathrm{lbs}$.

CONKEY'S MITE LIQUID

For painting roosts, fittings, the inside of

house, nest boxes, etc. Cans, qt., 60c; 2 qts., $90 \mathrm{c}$; gallon, $\$ 1.50$; 5 gals., $\$ 7.00$.

\section{CONKEY'S NOX-I-CIDE}

(Dip and Disinfectant)

For poultrymen. Nox-i-cide is indispensable as a red mite destroyer-paint it on the roosts and spray it into cracks.

Cans, pt., 50c; qt., 80c; 2 qts., $\$ 1.30 ; 1$ gal. $\$ 2.00$; 5 gals., $\$ 9.25 ; 10$ gals., $\$ 17.75$, not preaid.

\section{CONKEY'S FLY KNOCKER}

Dairymen, drivers, horsemen, stock raisers, cattlemen, sheep raisers declare this remedy the best investment they make-animals free from insects do better in milk and butter production.

Cans, qt., 60c; 2 qts., 90c; gal., \$1.50; 5 gals., $\$ 7.25 ; 10$ gals., $\$ 14.00$.

\section{CONKEY'S STOCK TONIC}

A general conditioner of real merit for live stock.

Pkgs., 35c, 65c, \$1.15, postpaid. Not prepaid, pails, 12 lbs., $\$ 2.10 ; 25$ lbs., $\$ 3.45$; bags, 50 lbs., $\$ 5.25 ; 100$ lbs., $\$ 10.00$.

\section{CONKEY'S POULTRY TONIC}

Every bird from chick to maturity will be more productive, healthier and more profitable if given a good tonic and regulator. Conkey's Poultry Tonic helps birds get more out of their feed.

Pkgs., 11/2 lbs., 35c; 31/4 lbs., 60c, post paid. Not prepaid, 7 lbs. $\$ 100^{\circ}$ pails, 12 lbs., $\$ 1.60^{\circ}$ 25 lbs., $\$ 3.00$; bags, 50 lbs., $\$ 5.50$; 100 lbs., $\$ 10.50$.

\section{McCLELLAN'S TOE PICK REMEDY}

An economical method for overcoming the vicious habit of Toe, Wing and Vent Picking among chicks. A few days use is all that is necessary to overcome this habit.

Price, 60c, postpaid.

\section{Black Leaf 40 Kills Lice}

Kills lice on your entire flock whether 50 birds or 5,000 . Use a small paint hrush; or squirt a thin line of "Block Leaf 40 " on the top of the roosts with a small oil can.

Works while they roost. So easy and effective that lice control is no longer a disagreeable, unwelcome task.

Packing and Prices F. O. B. DallasNot Mailable

Covers 1,900 to 2,400 running feet of roost.

10 lb. Tin

$\$ 11.85$

lb. Tin …............... 7.00

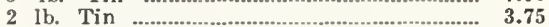

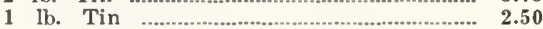

oz. Bottle ……......................................... 1.00

PETTY'S POULTRY PUNCII. Marks chicks by punching the web of the feet, cuts a clean hole and is convenient to use. $25 \mathrm{c}$ each, postpaid.

RELIABLE POUltRY PUNCh. Made in scissor shape, making it very easy to use. 40c each, postpaid.

COLORED CELLULOID LEG BANDS. Made in keyring shape, colors red, blue, green, yellow, purple. In ordering state kind of fowls wanted for, baby chicks or turkeys. 50 c per 100 , postpaid.

LEADER ADJUSTABLE LEG BANDS. Can be adjusted to any kind of fowl (num. bered). 60c per 100, postpaid.

P1GEON BANDS. "Bandettes" in colors, Pink, White, Blue, Yellow. 25 only, single numbers, $35 \mathrm{c} ; 25$ pairs, $65 \mathrm{c} ; 50$ pairs, $\$ 1.20$, postpaid.

THERMOMETERS. Tested incubator thermometer. $\$ 1.00$ each, postpaid. Tested brooder thermometers, 75c each, postpaid.

GOLD LEAF TOBACCO POWDER. Controls Round Worm in Poultry. Mix 2 Ibs, to 500 lbs. customary mash. Also used for dusting against poultry lice. 2-lb. package, 50c, postpaid.

\section{Miscellaneous Poultry Foods}

\begin{tabular}{|c|c|c|c|}
\hline & 10 & 50 & 100 \\
\hline F. O. B. Dallas & Lbs. & Lbs. & Lbs. \\
\hline Canada Field Peas & $\$ 1.25$ & $\$ 4.50$ & $\$ 8.50$ \\
\hline Pigeon Health Grit & .75 & 2.35 & 4.50 \\
\hline Sunflower Seed .... & 1.50 & & \\
\hline Fine Ground Bone & .75 & 2.50 & 4.7 \\
\hline Coarse Cracked Bone & .75 & 2.50 & 4. \\
\hline Meat Scraps & 1.00 & 3.50 & 6.5 \\
\hline $\begin{array}{c}\text { Charcoal (Medium, Fine, } \\
\text { Coarse) }\end{array}$ & .75 & 2.65 & 5.8 \\
\hline Oyster Shell (Coarse and & & & \\
\hline Fine) & .25 & .90 & 1. \\
\hline Pearl Grit & .25 & .90 & 1. \\
\hline
\end{tabular}

\section{POULTRY TINWARE}

We carry a complete line of poultry tinware-Fountains, Feeders, Hoppers, Brooders, etc. Ask for free catalog. per doz., post paid.

LIME NEST EGGS. Sold non-breakable. ceach; 50c per doz., postpaid.

CAPONIZING SETS. Capons make big profits. The inexperienced are successful.

\section{MARTIN'S POULTRYTONE}

is valuable as a tonic for Poultry that have been expos to blood sucking insects, $60 \mathrm{c}$ each: $\$ 1.10$ each, postpaid.

\section{Lee’s Gizzard Capsules}

Worm Your Birds This Better Way 5 Times as Effective as Medicines Given in

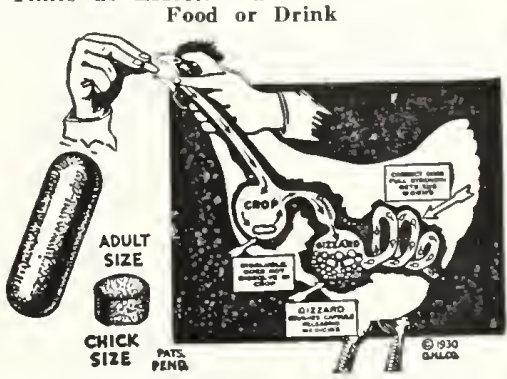

Being insoluble, the G12ZARD CAPSULE Beries the where the capsule is crushed, and the correct dose, FULL STRENGTH, pours directly into the intestines upon the worms. A triple combination medicine-for Tape, Round and Ceca worms.

The GIZZARD CAPSULE is the only in soluble capsule for worms in poultry. Patented, and name registered for your protec tion.

Worm your young birds at half grown with the Chick Size; worm all fowls (turkeys and chickens) before winter with the Adult Size G1ZZARD CAPSULE.

$$
\begin{gathered}
\text { Adult size-50-cap. pkg., } \$ 1.00 \text {; } \\
100 \text {-pkg., } \$ 1.75 ;
\end{gathered}
$$$$
\text { Chick size-50-pkg. 50c. }
$$

Please add 10c per package if wanted by parcel post.

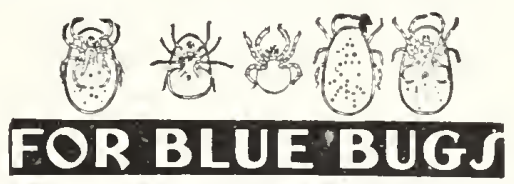

AND CHICKEN MITES IN THE POULTRY HOUSE USE MAR'TIN'S ROOST PAINT, an insecticide and wood preserver. This oil is gal., $\$ 1.60$, prepaid.

OLD ENGLISH SALT CAT FOR PIGEONS. Keeps pigeons in good health and prevents soft shell. Put up in brick form. $35 \mathrm{c}$ each, postpaid.

McCLELLAN'S BRONK-OL INHALAN'T is to be used as a Nasal Spray which is cooling and soothing agent to the mucous membrane of the throat and nostrils. For Poultry and Turkeys. Just spray above the qt., $\$ 1.50$, f. o. b. Dallas.

DR. CHAD'S REMEDY. A liquid guaranteed to cure white diarrhoea, canker mouth, worms, sore head, scaly legs, and roup. Kills Lice, Mites and Blue Bugs. 1-qt. bottle, 75c prepaid.

SALT BRICK. (Medicated). Put up in brick form for horses, mules, cattle, sheep and hogs. Is recommended as a worm destroyer, blood purifier, kidney regulator and appetizer. Place brick in feed box or con. venient place. $35 \mathrm{c}$ each, prepaid. 


\section{Goldfish, Fish Globes, Aquariums, Ornaments, Supplies}

\section{Goldfish}

Note: We do not guarantee live arrival of Gold Fish. If any loss, claims should be made by you against transportation company.

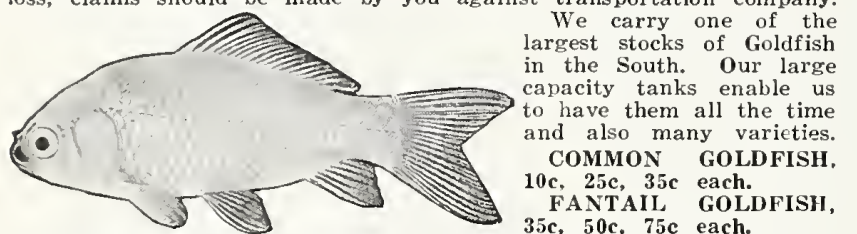
COMETS (long tails) GOLDFISH, 25c $35 c$, $50 c$, $75 c$ each. BLACK TELESCOPES (large eyes) GOLDFISH. 50c, 75c each. SHUBUNKINS (spotted, many colors) GOLDFISH, 35c, 50c cach. FOUNTAINS (extra large) GOLDFISH. \$1.50 each.

TADPOLES (aquarium scavengers). 10c each.

SNAILS (aquarium scavengers). 25c each.

FISH MOSS. $25 \mathrm{c}$ per bunch, postpaid.

SHIPPING BICKETS. Add 25c for 1 to 6 fish; 6 to 25 fish, $75 \mathrm{c}$.

All prices F. O. B., Dallas, except where noted.

\section{Fish Globes and Aquariums}

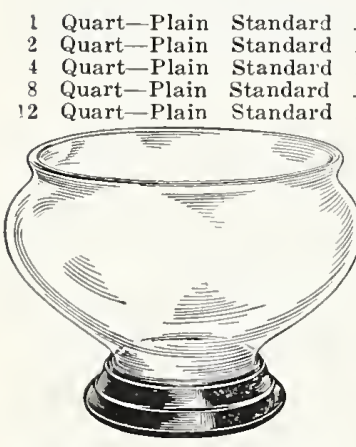

"D" BOWLS. 21/2 gallons, clear glass, $\$ 1.50$. Colored, blue, green, canary, \$2.25. 11/2 gallons, elear glass, $\$ 1.00$; Colored, blue, green, canary, $\$ 1.50$.

BLACK BASE for Style "D" Bowls; for $11 / 2$ gallon bowls, $40 \mathrm{c}$; for $21 / 2$ gallon bowl, 65c.

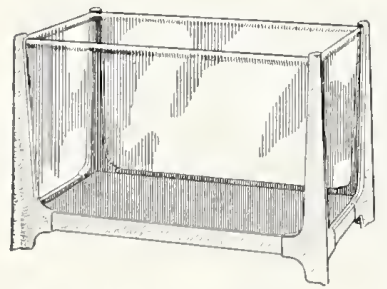

WIDE-MOUTHED BOWL. $21 / 2$-gallon capacity, crystal, $\$ 1.50$; with blue rim, $\$ 2.50$.

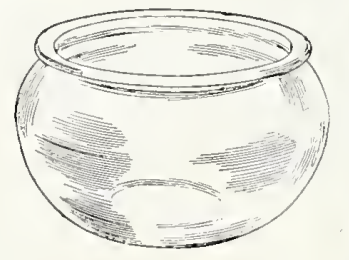

C A S T ALUMINUM AQUARIUMS. This is the most attractive and durable aquarium made. The aluminum frame makes it free from rust - can be painted to carry out any color scheme. Bottom is slate; made in three sizes.

12 in. long by 7 in. wide by 8 in. high, capacity 3 gallons, $\$ 11.00$. 16 in. long by 9 in. wide by 10 in. high, capacity 6 gallons, $\$ 13.50$ 20 in. long by 11 in. wide by 12 in. high, capacity 11 gallons, $\$ 17.50$.

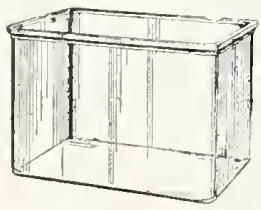

All Glass Aquarium

ALL GLASS AQUARIUM. 12 in. long by 9 in. wide by 9 in. high, $\$ 5.00$.

RUSTIC AQUARIUM

One of the most attractively designed aquariums, 18 inches long by 10 inches wide by $10 \frac{1}{2}$ inches high.

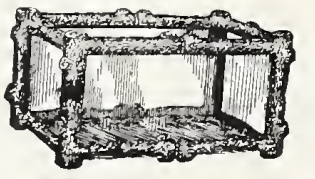

Capacity, 5 gallons. Each $\$ 15.00$ postpaid. postpaid.
"E" Bowl on Dolphin Base.

"E" BOWLS. 21/ gallons, clear glass, $\$ 1.50$; colored, blue, green, and canary, \$2.25. $11 / 2$ gallons, clear glass, $\$ 1.00$; colored, blue, green and canary, $\$ 1.50$.

DOLPHIN BASE. For 21/2 gallon bowls, $\$ 1.00$.

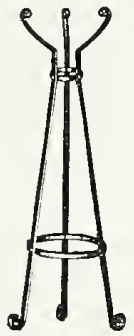

W ROUGHT I R O N STANDS. Can be adjusted to hold 1 gallon to 3 gallon standard bowl by bending top points. $\$ 1.50$.

WROUGHT IRON TABLE STANDS. Can be ad. justed to hold 1 gallon to 2 gallons, standard bowl.

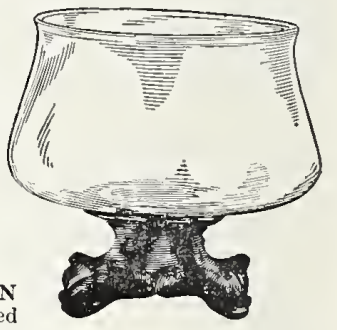
50c each.

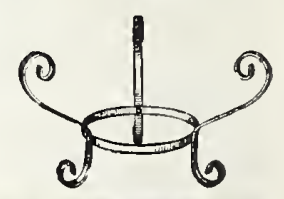

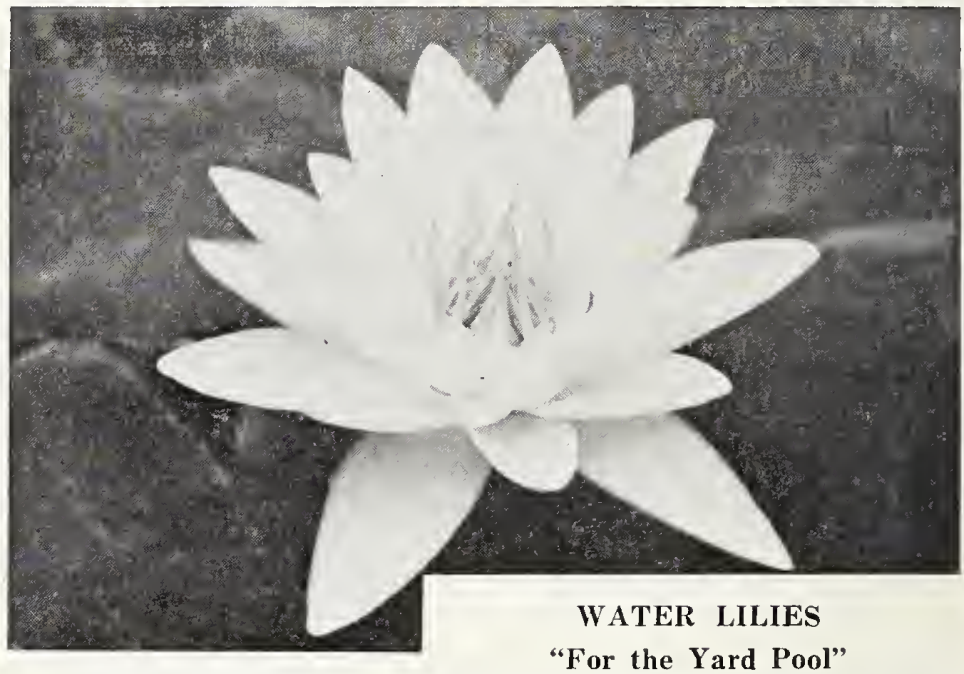

Every home is made more beautiful and more livable where there is a lily pool It can be enjoyed and appreciated in many ways. Stock it with goldfish and beautiful blooming water lilies. You will have a beauty spot that will be envied by the entire neighborhood.

We list below a few beautiful varieties. Prices are postpaid.

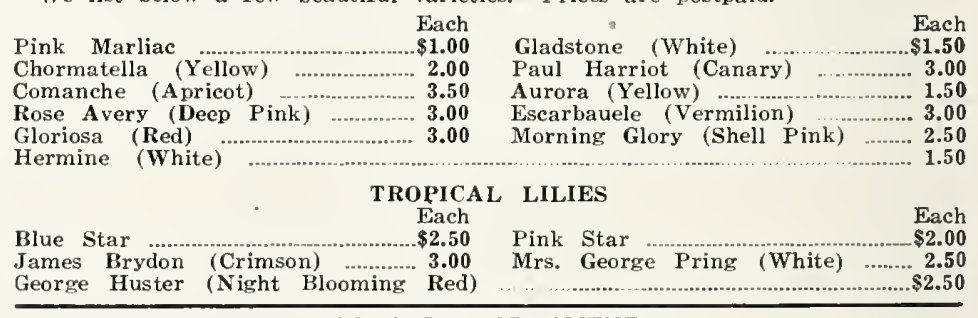

\section{AQUARIUM ORNAMENTS}

FISHER BOY. Negro boy or white boy in colored clothes, equipped with natural fish pole and line. Boy sits on seat that will fit globe or aquarium. \$1.35 each.

FELIX CATS. Hangs on edge of bowl or flower pots. Made of celluloid. 30c each, postpaid.

LIZARDS. China material. Color, yellow and black striped; about 5 inches long; hangs on side of globe or aquarium. $75 \mathrm{c}$ each, postpaid.

GREEN FROGS. China material. Hangs on side of globe or aquarium; about $3 \frac{1}{2}$ inches long. 60c each, postpaid.

GREEN ALLIGATOR. China material. To lay in bottom of bowl or aquarium About 6 inches long. 75c each, postpaid.

FLOATING GLASS BALLS. Beautiful color. Small size, 20c. Large size, 25c. 


\section{Aquarium Ornaments}

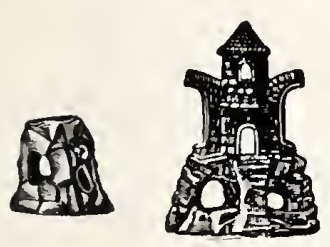

No. 1.

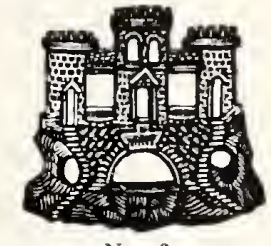

No. 3 .

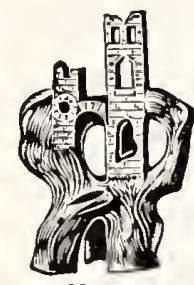

No. 4.

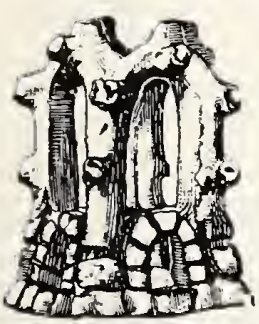

No. 5.

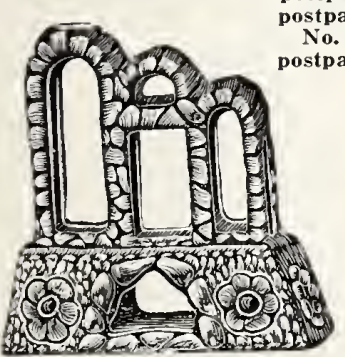

No. 6 .
No. 1. $2 \frac{1}{2}$ in. wide by $21 \frac{2}{2}$ in. high. $20 \mathrm{c}$ each, postpaid. each, postpaid.

No. 3. 5 in. wide by 5 in. high. $75 \mathrm{c}$ each, postpaid.

No. 4. 5 in. wide by 8 in. high. $\$ 1.10$, postpaid.

No. 5. In three sizes: $21 / 2$ in. wide by $31 / 2$ in. high, 25c, postpaid: $2 \frac{1}{2}$ in. wide by 4 in

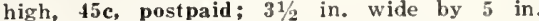
high, 60c, postpaid.

No. 6. In four sizes: $31 / 2$ in, wide by $4 \mathrm{in}$. high, $45 c$, postpaid; 5 in. wide by 5 in. high, $75 \mathrm{c}$ postpaid; 7 in. wide by 7 in. high, $\$ 1.10$, postpaid; 10 in. wide by 10 in. high, $\$ 2.25$, postpaid.

10 in. wide by 10 in. high, $\$ 2.35$, ostpaid.

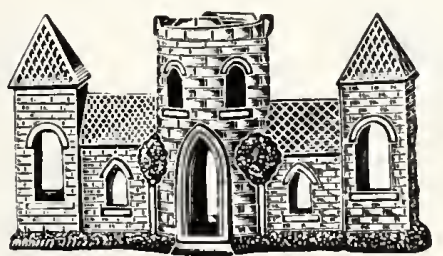

No. 7 .

AQUARIUM CEMENT. This is a special cement for aquarium only; ready for use. $11 / 4-\mathrm{lb}$. package, $\$ 1.40$, postpaid.

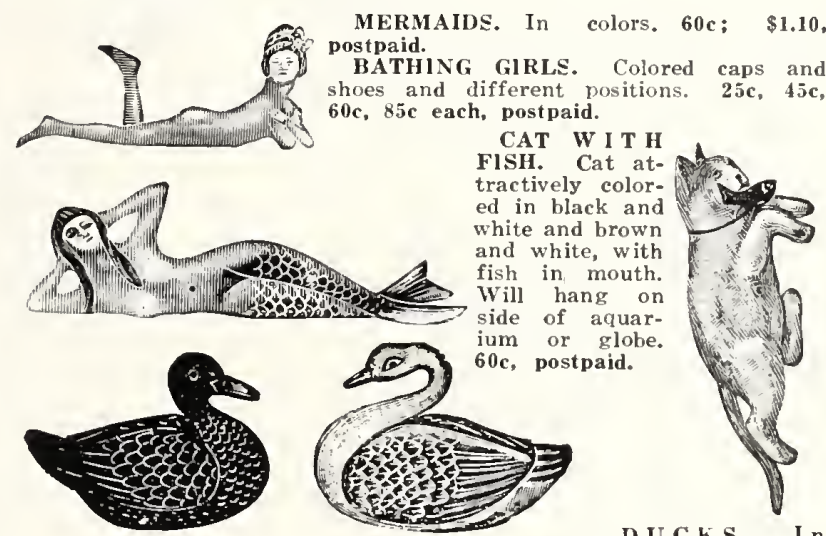

D U C K S. I $\mathrm{n}$ groups of three, $45 \mathrm{c}$ each, postpaid.

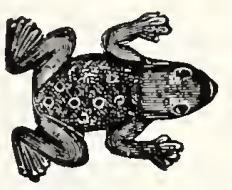

Natural Coloring-"Just Like Life," FLOUNDERS. 11/3 in. long, 10c each, postGR. GR paid.

TURTLES, 11/2 in. long, 15c each, postpaid. DUCKS. $1 \frac{1}{4}$ in. long, 10c each, postpaid. DUCKS. $2 \frac{1}{2}$ in. long, 20c each, postpaid. D1P NETS. For handling fish. 4 in. $35 \mathrm{c}$, postpaid; $71 / 2$ in., $90 \mathrm{c}$, postpaid.

NATURAL FISH FOOD. Especially for Gold Fish-in ground form or in wafers. Package, 15c, postpaid.

\section{Care and Feeding of Goldfish}

A Bowl or Aquarium of Goldfish is a Beautiful and Interesting Ornament for the home or office. An Aquarium cultivates a love for Nature with its growing plants and animated life. Assists in obviating the danger from Carbon Dioxide (in the air we breathe) which in diluted form causes headache, saps the vitality and renders one less resistant to disease, as the Aquarium helps to keep the house sufficiently humidified, thus helping to prevent respiratory infections such as Colds, Pneumonia, Tonsilitis, and the like. The Plants in the Bowls and Aquariums absorb this Carbon Dioxide from the air and convert it into fixed carbon; at the same time they give off an excess of life-sustaining Oxygen. In a Doctor's office with an overflowing ante-room of nervous patients, each dreading the ordeal, you will find a well stocked Aquarium conducive to mental and physical quietude. Goldfish are the natural enemy of the mosquito, which is the source of Malaria. Yellow Fever, Dengue and other diseases.

LIFE. Common Goldfish have lived more than thirty years, and even the most delicate of the fancy varieties can be kept ten years or more.

DISEASES. The overerowding of the aquarium and overfeeding are the means of killing more fish than anything else. Goldfish are not wholly exempt from diseases, though if properly cared for, are seldom sick. Salt water seems to be the best remedy for fish disease. When a fish is observed to be floating sideways, prepare a dish of water containing a tablespoonful of salt to a quart of water, place $\mathrm{fish}$ in it for two or three minutes, then remove to a larger vessel with a weak solutioin of salt water: say one-half teaspoonful of salt to a quart of water. Do this daily until better. A good preventive of disease is a weekly bath in salt water.

Water contains air and the fish breathe this air. After a time the air is exhausted in the water and it must be changed. Temperature and purity of the water are also important. Observation soon teaches how often water must be changed. When fish swim around well under the water and in a contented manner, you may be sure that everything is all right. If they keep to surface with mouth out (sucking air), an immediate change of water in whole are in part is required at once.

SUCCESS. Success with goldfish depends largely on intelligent treatment and proper feeding. Feed seldom (every other day) and then only so much as fish will eat in say fifteen minutes. Remove uneaten food so that it will not contaminate water. Keep aquarium
out of hot sun.

MOSS AND PLANTS. Moss and Plants growing in the aquarium throw off oxygen and it is this very oxygen that the fish require to sustain life. They also supply fish with a certain amount of food and add much to the beauty of the aquarium.

FISH FOOD. We consider the Natural Fish Food the best either in wafer or ground form. Feed pinch of ground food to each fish every other day.

NUMBER OF FISH. Sufficient room is essential to keep your fish healthy. The number of fish that can be safely kept in a globe or aquarium depends on their size and the size of the globe. For two medium size fish one gallon of water is necessary. Four fish two inches long will do well in one gallon of water if given proper care by changing water when temperature of room is warm. So under like circumstances twelve 2 -inch fish ought to do well in a 3 -gallon globe or aquarium.

TEMPERATURE. Extreme change of temperature must be avoided. It is a good plan to remove and replace only a part of the wate at a time. Let water stand in the room for a while after drawing it from faucet so that it will more nearly approximate the temperature of the water removed from aquarium.

BALANCED AQUARIUM. Water need be changed very seldom provided aquarium is not overcrowded and is well stocked with good growing plants, some snails or tadpoles as scavengers and proper care used not to overfeed and thereby foul the water. Fumes from paint or tobacco smoke sometimes make trouble. The remedy for impure or fouled water is changing it.

We guarantee our stock to be in good condition when shipped. If any loss or damage, claim should be made by you against Transpor. tation Company. 


\section{Birds, Bird Remedies, Cages and Supplies}

We carry one of the largest and most complete lines of Bird Supplies in the South. In fact, "Everything for the Bird." If your wants are not listed here, let us hear from wants are not listed here, let us hear from you. An
tioned.

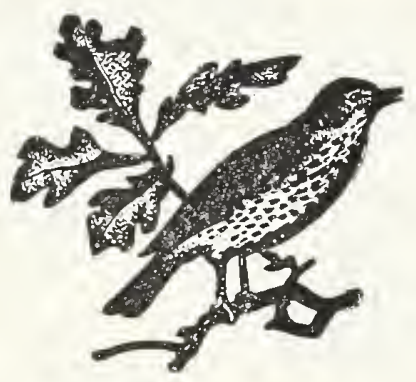

OUR GUARANTEE. We guarantee our Canaries to sing. If bird does not sing in one week's time, write us before returning. Bird may be returned and we will refund money or do not guarantee live delivery of any Birds. If loss occurs, claim should be made by you against transportation company.

"There is nothing more cheerful and pleas. ing than a sweet singing canary."

CANARY BIRDS. During the season, September until May-we carry in stock the finest imported, trained $S t$. Andreasberg Rollers and Hartz Mountain Canaries, the greatest of all trained singers. St, Andreasberg Rollers, $\$ 7.50$ each; Hartz Mountain, $\$ 5.00$ each. Female Canaries, strong and healthy, $\$ 1.25$ each.

PARROTS: PLEASE W R T T FOR PRICES.

SHELL PARRAKEETS OR LOVE BIRDS. Green or yellow. They are very interesting and beautiful plumed pets. Pair, \$5.00.

Blue, $\$ 10.00$ per pair.

\section{Bird Cages and Stands}

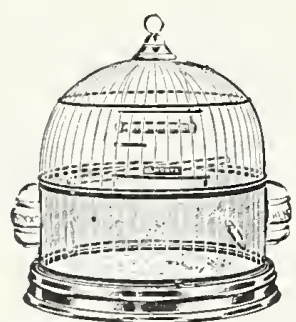

This is the style of cages mentioned below:

NEW ROUND BRASS CAGE

(Satin Finish)

Diam.

Body

$10 \mathrm{r} / 8^{\prime \prime}$

Height

$13^{\prime \prime}$

11

$113 / 4^{\prime \prime}$

$1434^{\prime \prime}$

Price

$\$ 4.00$

5.00

BRONZE TWO TONE

Diam.

Body

10 1/8"

$11^{\prime \prime}$

$113 / 4^{\prime \prime}$

Height

$13^{\prime \prime}$

$137 / 8^{\prime \prime}$

$143 / 4^{\prime \prime}$

\section{Bird Cages and Stands}

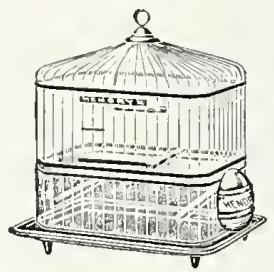

SPECIAL JAPANNED CAGES

$91 / 4 " \times 61 / 4 "$. Height, 125/8", \$2.00.

$103 / 8$ "x67/8". Height, $135 / 8 ", \$ 2.25$.

$11^{\prime \prime} \times 71 /$ " Height, $14^{\prime \prime}, \$ 2.50$.

$121 / 4$ "x $1 / 8$ ". Height, $145 / 8$ ", \$2.75.

$123 / 4$ " $\times 83 / 4$ ". Height, $151 / 4$ ", $\$ 3.00$.

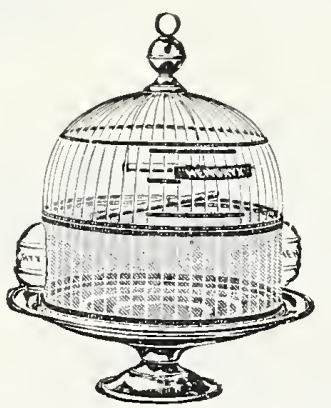

PEDESTAL ROUND JAPANNED CAGE Ivory Finish, with Wire Guard

Diam.
Body
$101 /$, $^{\prime \prime}$
$61 / 2 "$
$7 "$

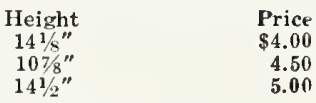

PEDESTAL ROUND BRASS CAGE

(With Wire Guard)

Diam.

Body

$10^{1 / 8^{\prime \prime}}$

$11^{\prime \prime} 13 / 4^{\prime \prime}$

Height
$153 / 8 "$
$155 / 8 "$
$171 / 4 "$

Price

\section{FANCY}

JAPANESE

DESIGN

(Duco Finish)

A very attrac. tive and stylishe cage.

In colors of Chinese Red and Black, Navy Blue and Gold, $\mathrm{P}$ e a Green and Black. Size as follows :

Diameter body, 10 inches. Height, $173 / 8$ inches. Price, $\$ 7.00$.
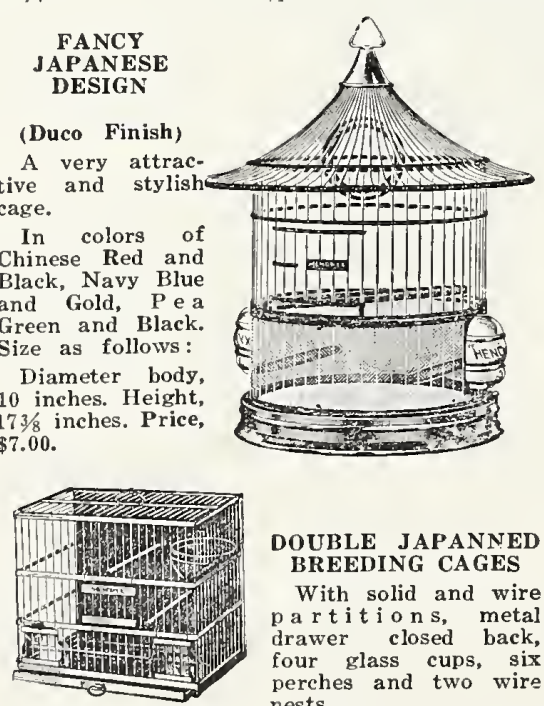

DOUBLE JAPANNED BREEDING CAGES

With solid and wire partitions, metal drawer closed back, four glass cups, six perches and two wire nests.

$171 / 4 "$ long, 83/4" wide, 14" high ............\$5.00 $191 / 2$ " long, $10^{\prime \prime}$ wide, 14" high................ 6.00 $22^{\prime \prime}$ long, 11" wide, $161 / 4$ " high ..................... 7.00 $241 / 2$ " long, $121 / 2$ " wide, $17^{\prime \prime}$ high ........... 8.00
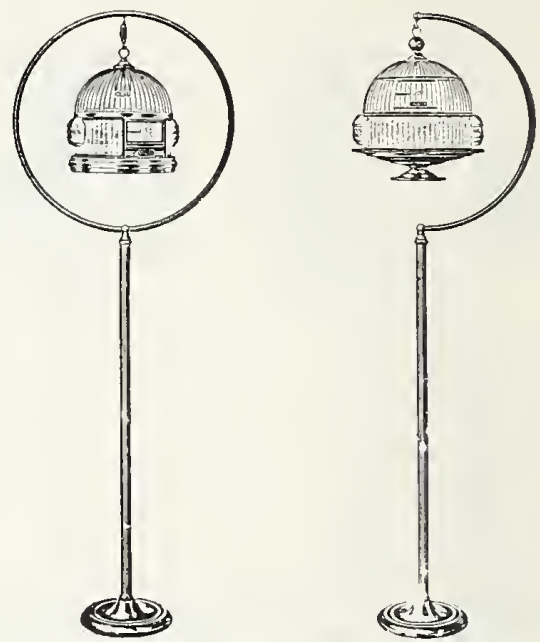

These stands are all 5 feet 5 inches high Full Circle Stands, in all colors, \$3.50. Half Circle Stands, in all colors, $\$ 3.00$. Colors are All Brass; Old Ivory; Blue and Gold; Bronz. Two Tone.

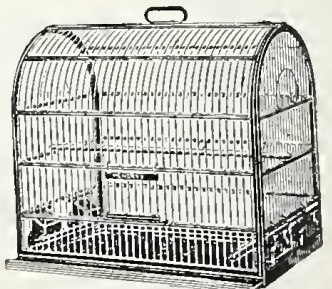

JAPANNED STOCK CAGES

(All Metal, with Drawer)

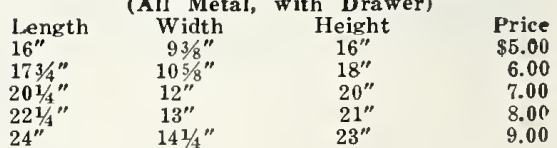

$24^{\prime \prime}$

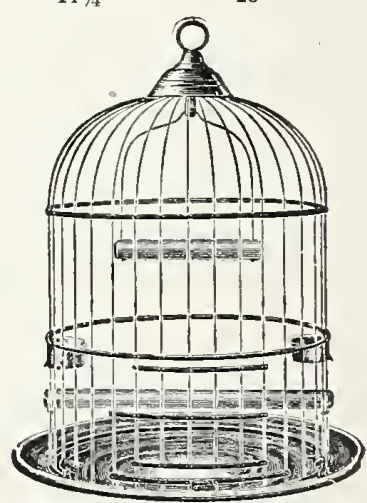

PARROT CAGES

These cages are constructed of very heavy tinned wire with extra large bottoms to pre. vent the birds from throwing the food be. yond them. They are so built as to make them indestructible. Equipped with tinned iron feed cups.

$\begin{array}{ll}\text { Diameter } & \text { Height } \\ 12^{\prime \prime} & 20^{\prime \prime} \\ 13^{\prime \prime} & 211^{\prime \prime} \\ 14^{\prime \prime} & 23^{\prime \prime} \\ 151 / 2^{\prime \prime} & 24^{\prime \prime} \\ 174^{\prime \prime} & 30^{\prime \prime}\end{array}$

Price $\$ 4.00$ 5.00 6.00 7.00 


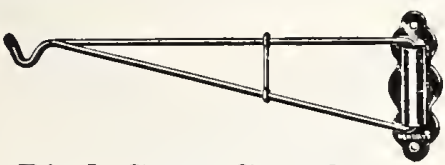

Bird Cage Supplies

BIRD CAGE HOOKS. For hanging the bird cage, protecting bird from cats and rats. $25 \mathrm{c}$ each, postpaid.

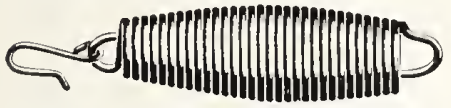

BIRD CAGE SPRINGS. Heavy, 20c Light, I0c. For Bird Cage Stands, 20c, oostpaid.

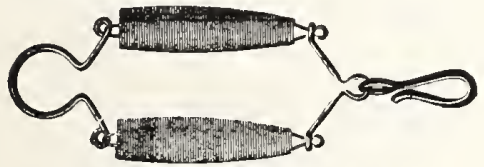

Double Spring, 35c, postpaid.

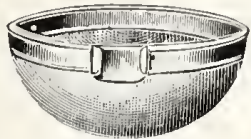

BIRD NEST. Wire with swivel to fit in any cage. $15 \mathrm{c}$ postpaid.

NESTING HAIR. For nest making of all eage birds, 15e each, postpaid.
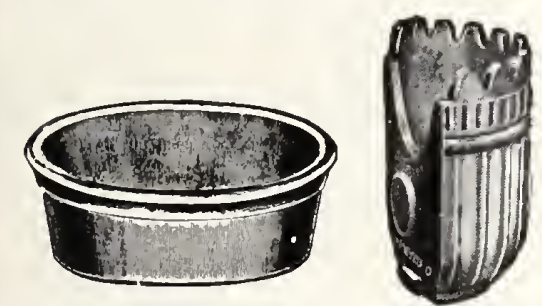

FEED AND WATER CUPS. Crystal, 20c each, postpaid. OpaI, 25c each, post paid.

BIRD BATH TUBS. Crystal, 20e each. Opal, 25c each, postpaid.

BRASS WIRE GUARD. To keep seed from being strewn out of cage, 50c per foot, postpaid.

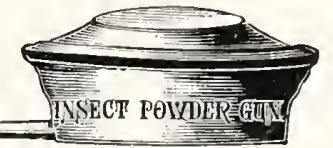

LOADED POWDER GUNS. Loaded with mite powder, 35c each, postpaid.

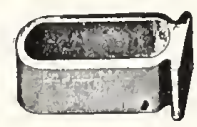

FOOD HOLDER. Used for feeding song restorers, etc. I0c each, post paid.

LEG BANDS. For Canary Birds. Aluminum Bands, numbered consecutively from 1 to 100. Doz., 25c postpaid.

\section{Bird Foods and Bird Remedies}

BIRD MANNA Every cage should have one hanging in it. A splendid health conditioner and song restorer. $20 \mathrm{c}$ each, postpaid. SING SONG. Makes the bird "sing a song". For health and song. 20c each, postpaid.

BURNETT'S SONG RESTORER. A splendid food for birds after moulting, in run-down condition- $\mathbf{a}$ builder and conditioner. $35 \mathrm{c}$ a bottle, postpaid.

MAGIC SONG RESTORER. A general health food for all seed-eating birds. It contains more food value and expensive ingredients than any song restorer ever placed on the market. Magic may be used as a regular diet as well as a tonic for both young and old birds, and for breeding or raising young birds. 35c each; 3 for $\$ 1.00$, postpaid.

MOCKING BIRD FOOD. For mocking birds and soft bill birds. Cans, 50c each, post paid.

ORANGE COLOR FOOD. Should be fed during moulting season. Will bring plumage out in a brilliant orange color. $30 \mathrm{c}$ each, postpaid.

BIRD BITTERS. A specific tonic for the restoration of song and an unfailing remedy for nearly all diseases of cake birds. Bottle, $35 \mathrm{c}$, postpaid.

MERICAN SALVE. Is an excellent application for sore feet, abrasions, rheumatism of cage birds. 35c postpaid.

PLUMAGE RESTORER. For restoring the plumage of parrots and canaries and other cage birds. 35c each, postpaid.
SPRATT'S NESTLING FOOD. A subatitute egg food, specially prepared with Cod Liver Oil, 25c, postpaid.

MOULTING FOOD. This food contains al the elements of an invigorating and healthpreserving diet for canaries and most of the smaller varieties of cage birds. 35c, postpaid.

MOULTING PEPPER. To be fed when birds start to shed feathers. 30c, postpaid.

MITE POWDER. Keep this on hand. The birds should be dusted occasionally. 30e. postpaid.

PARROT TONIC. A specially prepared tonic for parrots, cockatoos, etc. All cage birds require a little tonic medicine during moulting, and this tonic will be found most beneficial. $45 \mathrm{c}$, postpaid.

BIRD SAND. Should be kept in bottom of cage at all times. Packages, 25c, postpaid.

CUTTLE BONE. One of the necessitie for canaries, $5 c$ and I0c, postpaid. Bulk Cuttle Bone, 50c, per pound, postpaid.

MIXED BIRD SEED. Our bird seed i always fresh, carefully recleaned and well proportioned. These are the most important things pertaining to the health and song of the bird. 25e per pound, postpaid. 6 pounds, $\$ 1.00$, postpaid.

STRAIGHT CANARY SEED. 25c per pound, postpaid.

HEMP SEED. 25c per pound, postpaid.

BIRD RAPE SEED. 25c per pound, post paid.

BIRD MILLET, 25c per pound, postpaid. SUNFLOWER SEED. For the "Polly". $25 c$ per pound, postpaid. 6 pounds for $\$ 1.00$. postpaid.

\section{Books}

AQUARIA. Describing the various fish suitable for life in Aquariums with full instructions how to feed and care for them, breeding Gold Fish, making homemade aquariums, etc. Price, 50c, postpaid.

CANARY BREEDING AND TRAINING. A book on breeding, training and care of canary birds. Postpaid, 50c.

FEATHERED PETS. The food, breeding and care of canaries, parrots and other cage birds. Postpaid, 50c.

PARROTS AND OTHER TALKING BIRDS. Their food, care and training. Postpaid, 50c
Safe to Use

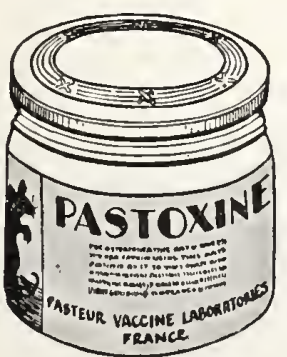

A Convenient Jar

\section{PASTOXINE}

TIIE NEW NON-POISONOUS EXTERMINATOR OF RATS AND MICE

PASTOXINE is the latest achievement of Science for the promotion of health and sanitation. It is a Product of the "LABORATOIRE DES VACCINS PASTEUR, P. E.", Paris, France.

THERE IS POSITIVELY NO DANGER OF ITS USE TO MAN, DOMESTIC ANIMALS OR POULTRY. It is non-poisonous as well as positively repulsive to them.

PASTOXINE possesses ingredients that are exceedingly appetizing to Rats and Mice, making Baits doubly effective.

PASTOXINE develops symptoms that bring Rats and Mice out into the open to die, thereby eliminating obnoxious odors.

PASTOXINE has been approved by the BOARDS of Health of leading cities from coast to coast, and they also passed by the control of U. S. Department of Agriculture upon its entry into this country, as not misbranded. (U. S. Department of Agriculture, Bureau of Chemistry, Lab. No. N. Y. PNF. 1380.)

Tests have constantly proven that PASTOXINE causes, in Rats and Mice, external symptoms similar to Progressive Asphyxia, viz. paralysis of the respiratory organs. The Rodents, as soon as they start being sick, eagerly search for WATER, and even more especially for AIR. This induces them to leave their holes, and they die in about six hours, out in the open air, whele the carcasses can be easily detected and removed. Price, 60c, post paid.

WE ARE EXCLUSIVE STATE DISTRIBUTORS OF PASTOXINE.
Rats Spread

Disease

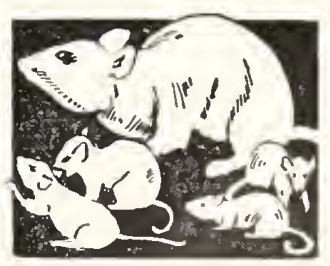

Kill These

Pests 


\section{Delcreo}

For Distemper, Colds and Pneumonia. $A$ sure cure of the dreaded and most destructive discase of the Dog.

Ask any kennel or dog breeder about "Delcreo". For all canine diseases, such as pneumonia, bronchitis, diarrhoea, catarrh, colds, etc. 4-oz. bottle, $\$ 1.50$, prepaid.

SPRATT'S DOG CAKES. A splendid conditioner and food for the dog; in $1 \mathrm{lb} .15 \mathrm{oz}$. packages. 50c, prepaid.

SPRATT'S PUPPY CAKES. They are medicated, they are sound and wholesome food. They prevent constipation, which so frequently distresses domestic animals. 60c, prepaid.

\section{California Dog Foods}

"ALWAYS FRESH"
DOG BISCUITS. Are made of the highest rade whole wheat Flour, Cereals, Calcium f Lime and contains $20 \%$ meat.

KIBBLE is the Dog Biscuit broken up into medium pieces.

TERRIER FOOD is similar food to the Kibble but is of smaller broken pieces.

PUPPY MEAL is a meal made from the Dog Biscuits which contains meat, whole wheat flour, cereals, and calcium of lime. Prices of all above Dog Foods, lb., 15c: lbs., $\$ 1.00 ; 100$ lbs., $\$ 12.50$, f. o. b. Dallas. VIGO DOG FOOD. A canned meat product containing meat, the balance being vegetables, cereals, oils, and calcium of lime. This food is considered one of the finest canned meat Dog Foods that has ever been produced. Per can, $20 \mathrm{c} ; 6$ cans, $\$ 1.00$, postpaid.

\section{Clayton's Dog Remedies}

If you own a dog, take good care of him. Feed him regularly and treat him with remedies scientifically prepared. The following remedies are put up by the great dog specialist, Dr. Clayton. All prices on Clayton's Remedies prcpaid.

COD LIVER OIL. This is a palatable emulsified cod liver oil with hypophosphites of lime and soda. A wonderful health and bone builder for weak and undernourished grown dogs, puppies, cats, and kittens. Price, 1.00.

MANGE REMEDY (Oily dark color). For skin disease. 60c.

SKIN LOTION (Colorless). 60c

\section{Dog Supplies}

HAIR TONIC. For the hair. 60c.

CONDITION PILLS WITH PEPSIN. A very reliable remedy in all run-down conditions of the system, especially valuable in distemper. $60 \mathbf{c}$.

KETERALINE. Liquid (Tablets). For distemper. $60 \mathrm{c}$.

ALTERATIVE PILLS. Especially useful in Eczema and all skin diseases. 60c.

CARMINATIVE TABLETS. For all forms of indigestion. 60c.

LAXATIVE PILLS. Act directly on the liver and secretions and keep the bowels in good condition. 60c.

WORM PILLS. Are composed of the very best remedies known for the expulsion of worms. $60 \mathrm{c}$.

TAPE WORM EXPELLER. Is especially prepared for tape worm. 60c.

VERMIFUGE. Liquid (Soft capsules) Slayton's Vermifuge can be given to puppies after they are ten days old (the best time to begin to treat puppies for worms) and to dogs of all ages and breeds. 60c.

CANKER LOTION. Liquid. For external and internal canker, deafness, etc. 60c.

EYE LOTION. Liquid. For all diseased conditions of the eye. 60c

SEDATIVE. Liquid. For all kinds of fits and convulsions, epilepsy, etc. 60c.

COUGH SYRUP. For coughs and colds from whatever cause. 60c.

PUPPY TONIC. To strengthen weak puppies, relieve them of colic, prevent and stop bloating and formation of gas in the stomach and bowels. $60 \mathrm{c}$.

BOWEL CONSTRINGENT TABLETS. 60c. DIURETIC. Liquid. 60c.

CHOREA TABLETS. 60c.

GOITRE MEDICINE. To relieve enlarged lands of the neck, Goitre. $\$ 1.00$.

CEOLINE DOG WASH and DISINFECTANT. For fleas. For washing your dog. To disinfect your kennel. A perfect disinfectant for any and all purposes a disinfectant is used. $35 c$.

CEOLINE SOAP. This soap contains the same ingredients as our celebrated Ceoline dog wash and disinfectant. 25c.

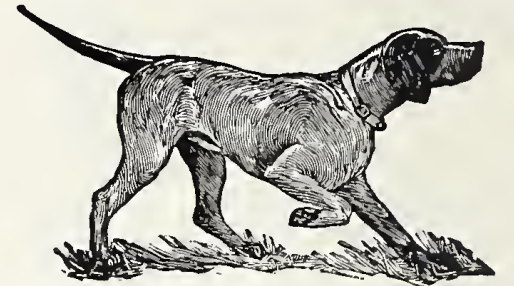

SHAMPOO. For washing dogs, non-poisonous, leaves the coat bright, clear and glossy. (Excellent Shampoo for people) 25c.

DOG SOAP. This soap is prepared especially in reference to the nature of the dog's skin: can be used continually without injury to the dog's skin or coat, but will keep both in good condition. 25c.

KILFLEA SOAP. For fleas. 25c.

KILFLEA POWDER. For dogs and cats.

\section{Rabbit Supplies and Remedies}

All Prices F. O. B. Dallas.

COLDS. Spray with MeClellan's Bronki-ol Inhalant above the heads and around in the hutches daily so Rabbits are forced to breathe or inhale the vapors. 8 ozs., 50c; qt., $\$ 1.50$, f. o. b. Dallas.

Ear Canker Remedy ........................ \$ Slobber Remedy

Eye

Ointment .........

Tonic and Regulator

SULPHUR SALT SPOOLS. "A Necessity." Just hang in hutch where Rabbit can lick them. Price, 10c each; doz., $\$ 1.00$, postpaid.

RABBIT BOWLS. Used for feed or water. Rabbits cannot get in them or waste the food. Shipping weight 4 lbs. 25c each.

TATTOO PENS. For marking Rabbits. $85 \mathrm{c}$ each, postpaid.

TATTOO INK. Bottle, 45c, postpaid.

RABBITS. We handle rabbits all the year. Let us know the breed you want. We will be pleased to quote you prices.

\section{Insecticides and Fungicides}

\begin{abstract}
"BLACK LEAF 40" A highly concentrated nicotine solution for spraying. Kills aphis, thrips, leaf-hoppers
and many other insects. Does not injure foliage. World's and many other insects. Does not injure foliage. World's ment Stations and leading growers. We have an enormous demand for this article. 1-oz. bottle, 35c; 5-0z. bottle, $\$ 1.00$; 1-lb., $\$ 2.50 ; 2-1$ b. tin, $\$ 3.75 ; 5$ lbs., $\$ 7.00$ 10-lb. tin, $\$ 11.85$; f. o. b. Dallas. (Not mailable).

BORDEAUX MIXTURE (Powdered). Used in dry powdered form and in solution; splendid for fungous diseases and mildew.

HOFSTRA (Powder use only). A non-poisonous insecticide for home, firm or store. Affects certain insects guaranteed to kill flies, mosquitos, ants, bedbugs, roache chicken mites, lice, fleas on dogs and cats, potato bugs
and cabbage worms. Harmless to human anatomy. Sold and cabbage worms. Harmless to human
\end{abstract}

HAMMOND'S SLUG SHOT. An insecticide for garden use. One of the cheapest and best powders used to destroy potato bugs, cabbage worms, cucumber beetles and similar leaf-eating insects. 1-lb. pkg., 20c; 5-lb. pkg., 65c; 10-lb. pkg., $\$ 1.25$, f. o. b. Dallas. Dusters for applying Slug Shot, $75 \mathrm{c}$ each.

CARBOLA (Powder). Used instead of whitewash and disinfectants. Ready as soon as mixed with water; can be applied with brush or spray. A germ-killing white paint. Used on trunks of trees and poultry houses and buildings. 5 lbs., $\$ 1.00 ; 10 \mathrm{lbs}$., $\$ 1.50 ; 50 \mathrm{lbs}$. $\$ 5.50$, postpaid.

TOBACCO DUST. For fumigating and dusting plants, also controls round worm in poultry. Lb., $20 \mathrm{c} ; 10 \mathrm{lbs}$., $\$ 1.50 ; 25$ lbs., $\$ 2.50$, prepaid. WHALE or FISH OIL SOAP. Used as a wash, thus preventing the spread of scale. Lb., 50c, prepaid.

SNAROL. This, is an effective bait for controlling sow bugs, slugs, cutworms, grasshoppers, snails, etc. Snarol is not injurious to plants or other vegetation and is not soluble in water. $1 \frac{1}{2} \mathrm{lbs} ., 50 \mathrm{c} ; 4 \mathrm{lbs}$. 1.00, f. o. b. Dallas.
EFFECTIVE against most plant insects, including cucumber and melon beetles, cabbage worms, rose etc.

SAFE-Kills only insects-harmless to man, livestock, birds and pets.

NON-INJURIOUS-Spray freely on

the tenderest plants. Won't injure the ground.

EASY to USE-Just mix with water and stir. No unpleasant odor. WON'T GUM SPRAYERS-No bad effect on metal or rubber. Stays in solution and can't clog sprayers.

Prices, f. o. b. Dallas, 1-oz. bottle, 35c; 6-oz. bottle, $\$ 1.00 ; 16-0 z$. bottle, $\$ 2.00 ; 32-0 z$. bottle, $\$ 3.50 ; 1-$ gal. bottle, $\$ 11.50$. (Mailable).

QUA-SUL. For blight, mildew and many fungous troubles. Diseaseinfested soil in plantations, orchards, vineyards, farms and gardens restored to healthy condition and made fruitful by the use of QUASUL. It destroys fungous spores, larvae and eggs of pests and at the same time is a stimulant for the plants growing in that soil. Keep your greenhouses and garden clean with QUA-SUL. QUA-SUL is a sulphur-carbon compound immediately soluble in water which has remedied more growers' ills than anything else that has been introduced on the market. For mildew it is giving universal satisfaction. For brown rot and oak fungus on trees, black spot on vegetables and flowering plants, 4-oz, bottle, 35c;8-oz, can, 60c; 1-qt. can $\$ 1.25$. 1 -gal. can, $\$ 4.00$; f. o. b. Dallas.

PARIS GREEN. This insecticide is a sure killer to all insects, but should be mixed and handled with greatest care, as a mixture made the least too strong will injure or burn the plants, 1/1-lb. pkg. 20c: $1 / 2$-lb. pkg., 35c; lb., 60c; 4 lbs., $\$ 2.00$, f. o. b Dallas. (Not mailable).

TREE TANGLEFOOT. Tree Tanglefoot is a paste preparation for painting around the trunks of trees in the form of a band. Caterpillars and other crawling pests cannot get over it. 1-lb. can, 60c, f. o. b. Dallas. 


\section{Tested Seeds for}

\section{INSECTICIDES AND FUNGICIDES (Continued)}

DRY LIME-SULPHUR. Very effective remedy for scale and fungous troubles. Used mostly for dormant spraying. 1-lb. can, 40c ; 5 lbs., $\$ 1.50 ; 10$ lbs., $\$ 2.50$, f. o. b. Dallas. (Not mailable).

PRUNING COMPOUND. The very thing for use after pruning trees. A specially prepared thick paint with a rubber elastic film. Qt., 75c; gal., $\$ 2.00$, f. o. b. Dallas.

GRAFTING WAX. Used for grafting work on all kinds of trees. Lb. 70c, postpaid.

ARSENATE OF CALCIUM (Powder). Used either in dry form or solution. Lb., 60c; 5 lbs., $\$ 2.00$, f. o. b. Dallas. Ask for prices in larger quantities. Sure death to chewing insects. (Not mailable).

ARSENATE OF LEAD. (Dry Powdered). Makes more solution than other insecticides. May be used in powder form mixed with lime for dusting or as a liquid spray. Directions on each package. Lb., 50c; 4 lbs., $\$ 1.60$, f. o. b. Dallas. Ask for prices in larger quantities. (Not mailable).

\section{Formula \\ for Exterior Whitewashing} BY U. S. DEPARTMENT OF AGRICULTURE

Weatherproof for build ings, fences, etc. (1) Sixtytwo pounds (one bushel) quick lime, slake with twelve gallons of hot water. (2) Two pounds common table salt, one pound sulphate of zinc; dissolve in two gallons of boiling water. (3) Two gallons of skimmed milk. Pour (2) into (1) then add the milk (3) and mix thoroughly.

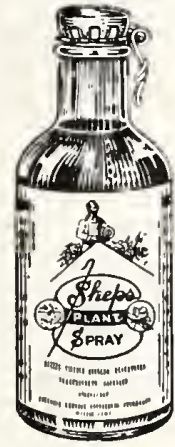

\section{Sheps Plant Spray}

\section{Kills Only Insects}

Assure your plants of positive protection against insects. SHEPS NonPoisonous Plant Spray controls and kills both sucking and chewing insects, including Aphids, Thrips, Green Flies, White Flies, Mealy Bugs, Worms, Cater-
pillars and others. GUARANTEED NON-POISONOUS

Absolutely safe for humans, birds, animals and plants. Sure death to insects. Will not injure the most delicate blooms or plants. Benefits soil and foliage.

The easiest spray to mix. SHEPS Plant Spray is poured

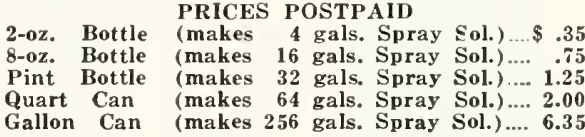

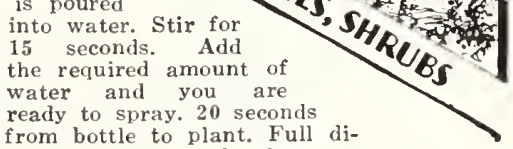

(makes 256 gals. Spray Sol.) $\mathbf{6 . 3 5}$ rections on each bottle.

\section{Protect Your Trees From These Hidden Enemies}

The peach tree borer (Sanninoidea Exitiosa Say) feeds actively in the fall, spring and summer months, and lies dormant during the winter. It attacks the soft inner layer of bark usually just beneath the ground and sometimes along the larger roots. The presence of these pests is indicated by masses of gum mixed with brown frass or "sawdust" exuding from the injured trunk. The borers become full grown from the middle of June to the first of September, and then spin silk cocoons which hatch into clear winged moths. During the six days these moths are alive they lay from 200 to 800 eggs - which shows what a menace they will become if not properly checked.

SANTOCHLOR WILL KILL THEM

The popular and modern way to rid your orchard of these worms or borers is to apply Paradichlorobenzene around the base of all trees. Monsanto's trade name for this product is SANTOCHLOR,

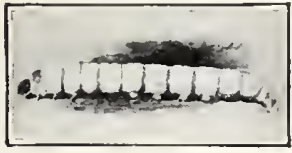

Tree Borer which is unadulterated Paradichlorobenzene, practically 100 per cent pure, It is a white crystalline substarice that changes to a gas heavier than air and penetrates the burrows of the borers. It is fatal to insects, but will not harm man or domestic animals unless taken internally. The SANTACHLOR method has rapidly replaced the old-fashioned "worming" process for control of borers. Digging the worms out with a knife may be as injurious to the tree as the worm. In two "wormings" with a knife it is seldom possible to get more than $90 \%$ of the pest. With SANTOCHLOR, however, it is a common occurrence to kill from $95 \%$ to $100 \%$ with one application, and it is also a great deal less bother. A RING OF DEATH

SANTOCHLOR is applied to the cleaned surface of the ground around the base of the tree, after any masses of gum have been removed from the tree trunk. The trunk should be completely encircled by one ounce of the white crystals, care being taken to leave two inches space between the trunk and the inside of the white band. This mound is then covercd with fine earth and packed down firmly. One treatment per year, in the fall preferably, will usually be sufficient protection.

Complete directions, together with the best times to apply for different States, appears on every
package.
COST IS LOW-ORDER NOW package.

Able to

Don't postpone the use of SANTOCHLOR. Order a handy carton and see for yourself what this poduct will do for your trees.

Pound cans, $75 \mathrm{c} ; 5 \mathrm{lbs}$., $\$ 2.75$, postpaid. If wanted in larger quantities write for prices.

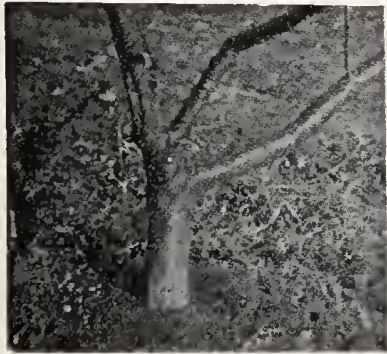

Fig. 1.

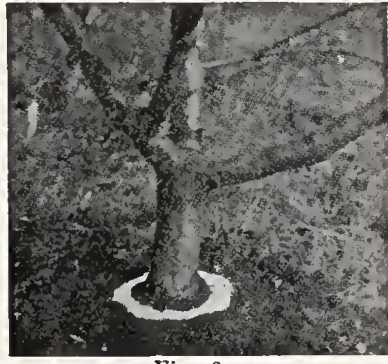

Fig. 2.

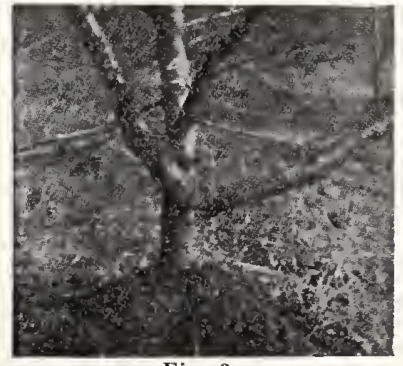

Fig. 3.
Fig. 1. The soil about the peach tree made smooth and ready for treatment.

Fig. 2. A correct treatment. on e ounce of finely divided paradichloroben. zene placed on the soil about the tree in a continuous narrow band approxi. mately 2 inches from the tree.

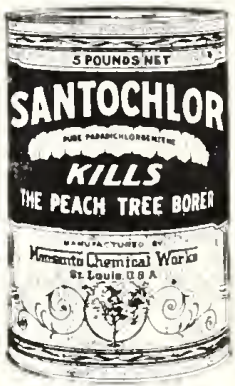

Fig, 3. Four to six shovelfuls of dirt f etc., placed on top of the paradichlorobenzene, 3 to 6 inches deep and packed dow.

IN BEEHIVES. SANTOCHLOR is recommended for use in beehives to keep out moths.

FOR HOUSEHOLD USE. Keeps moths out of clothes and used as deodorant.

\section{ANTROL Kills Ants}

ANTROL "Kills Ants". A scientific ant control. It consists of small glass containers, filled with special Antrol Syrup and placed around homes and gardens according to simple directions. Ants carry the poison to their nests destroyed. Complete set of four containers and 4-oz. bottle of 


\section{Sprayers and Dusters for Insecticides}

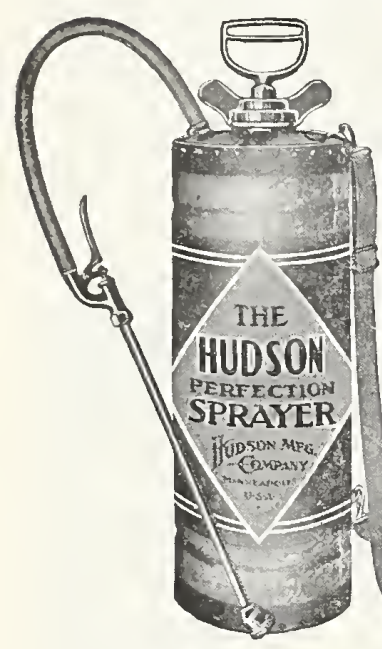

\section{Hudson Perfection Sprayer}

For general high pressure purposes, the Perfection is the very best. Easily operated and economical to use for whitewashing, disinfecting, deodorizing, cold water painting, ete. Best materials, best construction and best quality throughout.

Tank-71\% inches in diameter, 20 inches high, capacity about 4 gallons, Made of rust-resisting, copper-bearing galvanized, or first quality brass sheets, as ordered. Riveted like a range boiler and will withstand any pressure with perfect safety.

No. 110G Perfection Sprayer. Galvan ized. $\$ 7.00$, f. o. b. Dallas.

No. 110B Perfection Sprayer. Brass $\$ 10.00$, f. o. b. Dallas.

Shipping weight of each, 13 pounds.

\section{Hudson Junior Sprayer}

The Junior Sprayer is made for the man who needs a medium sized, nigh pressure compressed air sprayer. It is particularly adapted for the back yard garden or small
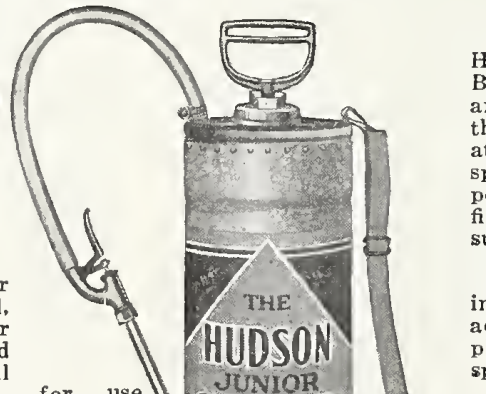
Hudson Barrel Pump equipped with a Hudson No. 27 Spray Boom. By mounting the No. 4 Pump in a barrel, which is placed in a cart. and attaching the boom to the back of the cart just high enough to clear the rows, the farmer or planter has a high pressure 4-Row Sprayer at a very small cost. It is very desirable for use with all kinds of spraying solutions on potato fields, cotton fields, and for other pur. poses. For spraying potatoes or cotton, it has a capacity of ten to fifteen acres per day. The pump may be used for other purposes. such as whitewashirg, orchard spraying, etc.

Boom is equipped with four Fog nozzles, adjustable for rows 32 inches to 48 inches apart. Extension rods carrying the nozzles are adjustable to the pipe, making the boom easy to handle in narrow places, and in fence corners. Rods may be set at right angles for spraying grapevines, etc.

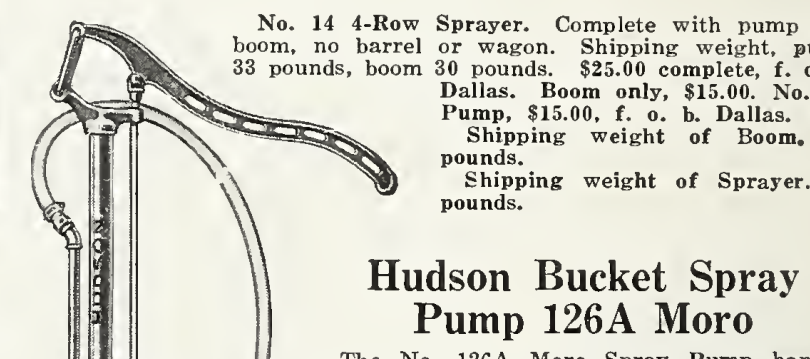

The No. 126A Moro Spray Pump handle all spray solution. It develops a high pressure, adapting it for use in small orchards. vineyards, and truck gardens; for whitewash and cold water plants; with insecticides. fungicides, disinfectants, stock dips, etc.

Valves are bronze balls mounted in a brass cage, accessible without dismantling pump. Cylinder is seamless brass. Air chamber has ample capacity for high pressure and continuous discharge. Agitator is dasher type. all metal. Easily adjusted and will prevent the spray material from settling out. Foot rest is malleable and unbreakable. Equipped with two feet of $3 / 8$-inch 5 -ply high pressure spray hose, a 12-inch iron extension rod and regulator Fog nozzle, adjustable for various sprays from finest mist to solid stream. $\$ 6.50$. f. o. b. Dallas. Shipping weight, 11 pounds. and Ideal Angle nozzle. $\$ 15.00$ f. o. b. Dallas. Shipping weight, 35 pounds.

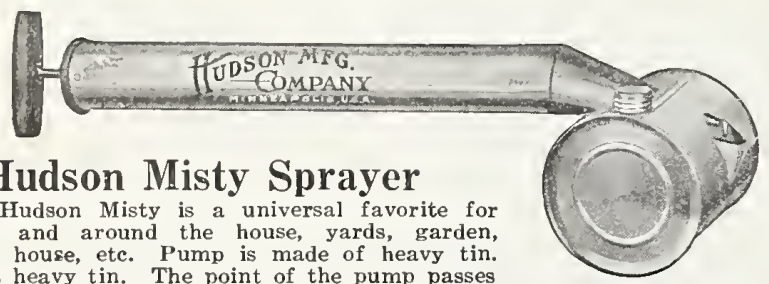
in and around the house, yards, garden, chicken house, etc. Pump is made of heavy tin. Tank is heavy tin. The point of the pump passes through the tank and is securely soldered. Siphon tube is set at trength, simplicity, neatness and uniform efficiency in operation. Heavy plunger rod and good leather. Capacity one quart. 50c each, not prepaid. Shipping weight, $11 / 2$ pounds.

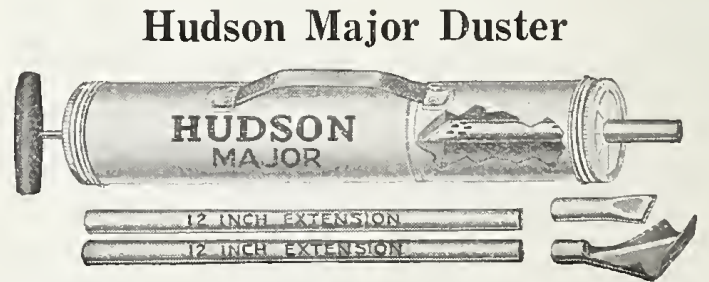

The Major handles Paris Green, arsenate of lead, and similar poisons in powder form very efficiently. It is used in the home garden. poultry house, dairy barn. Price, $\$ 1.25$, f. 0. b. Dallas. Weight, 2 lhs 


\section{Hudson Midget Sprayer

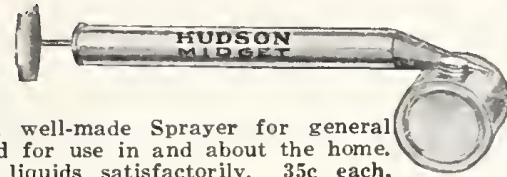 \\ The Midget is a small, well-made Sprayer for genera
purposes, especially adapted for use in and about the home. Will handle all kinds of liquids satisfactorily. $35 \mathrm{c}$ each,}

not prepaid. Shipping weight, 1 pound.

\section{Hudson Continuous Sprayer}

Is constructed with a detachable Mason jar. Has an unusually large opening for convenience in filling and cleaning, etc. The variable nozzle is instantly adjustable for any solution or any type of spray from the finest fog to solid stream. Removing the adjustable nozzle cap instantly releases the siphon tube for removal, a feature found in no other type of continuous sprayer. All working parts are brass. Operates very efficiently with insecticides and disinfectants in the home, schools, hotels, theaters, etc., with penetrating oils, etc. Heavy tin, $\$ 1.00$ each. Brass, $\$ 1.50$ each, f. o. b. Dallas. Shipping weight. $11 / 2$ pounds.

\section{Hudson Sunshine Sprayer}

The Sunshine Wheelbarrow Sprayer wa designed particularly for the florist of nurseryman. Its short, compact construction permits its use in narrow greenhouse rows, and in close quarters. It is also adapted for spraying small orchards, vineyards, truck gardens, berry bushes, etc. A very convenient and efficient rig for whitewashing and disinfecting poultry houses, dairy barns, hog pens, spraying stock dips and poultry remedies, treating ornamental shrub.
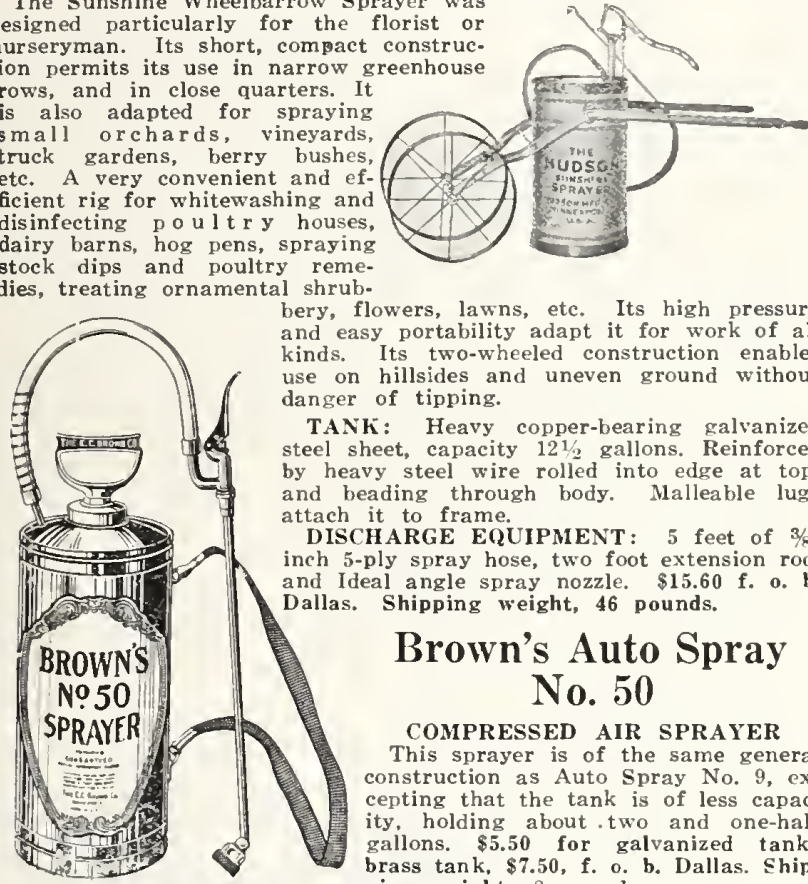
easy portability adapt it for work of al Its two-wheeled construction enables on thides and uneven ground without of tipping.

Heavy copper-bearing galvanized sheet, capacity 1212 gallons. Reinforced nd beading through body. Malleable lugs it to fram oray hose, two foot extension rod Ideal angle spray nozzle. $\$ 15.60 \mathrm{f}$. o. Dallas, Shipping weight, 46 pounds.

\section{Brown's Auto Spray} No. 50

COMPRESSED AIR SPRAYER

This sprayer is of the same general construction as Auto Spray No, 9, excepting that the tank is of less capacity, holding about two and one-half gallons. $\$ 5.50$ for galvanized tank: brass $\operatorname{tank}, \$ 7.50$, f. o. b. Dallas. Shipping weight 8 pounds.

BROWN'S AUTO SPRAYER No.

5. The ideal all-purpose hand sprayer. "In a class by itself." Its field is practically unlimited as it may be used for spraying trees vines, gatden truck and any field crop. This pump is made entirely of brass. The nozzles regularly THE SAME SPRAY WITH HALH turnished with this

cial design so this sprayer can be used on trees the heig't of a pear tree as wel as on bushes near at hand. Also $2 \frac{1}{2}$ feet of $1 / 2$-jnch suction hose w it h heavy strainer or extension

so it will not work out of bucket or tank while being used. $\$ 5.00$. f. o. b. Dallas. Shipping weight, 4 pounds.

KNAPSACK TANK FOR BROWN'S AUTO SPRAYER No. Hangs at small of back with straps over shoulders, thus allowiny you to direct spray and be on the move all the time Made of galvanized iron: convenient and nractical. \$3.70, f. o. b. Dallas. Ship ping weight. 7 pounds.

\section{Brown's Auto Spray No. 5}

IT'S DOUBLE ACTING

\section{Brown's Auto Spray No. 9}

COMPRESSED AIR SPRAYER

The latest construction in compressed air sprayers. It is high class and is warranted gainst mechan. ical defects. Two pumpings of about 15 strokes on the plunger will discharge the con. tents under high and constant pressure. Used for spraying trees, field crops, shrubs, vines, greenhouses and poultry houses. Holds about 4 gallons. Galvan ized tank, \$6.75; brass tank, \$9.75, f. o. b. Balla. Shipping weight, if lbs.

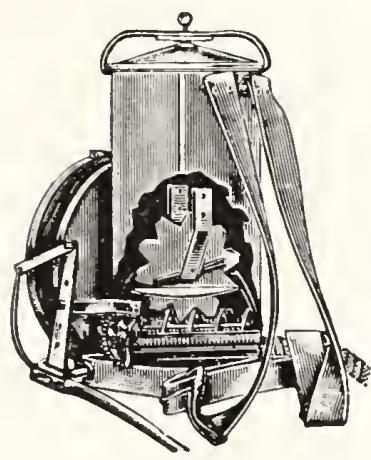

California Beauty Duster

Just the thing for small truck farm acreages. Holds twelve pounds of dust. Throws cloud twelve feet. Weighs nine and one-half pounds. Feed instantly adjustable. Equipped with hose, tubing and spoon to reach the under side of leave on the ground without stooping. $\$ 13.50$ f. o. b. Dallas. Shipping weight, $10 \mathrm{lbs}$.

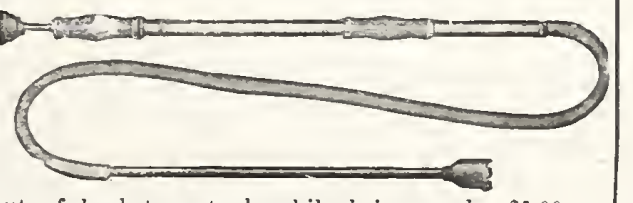

Simplicity

1.00

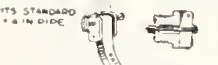
the Watering Problem

Float Turn: Up to Clean Bowl fect in operation you will marvel you did not think of it yourself. Easy to attach-nothing to get out of order. A hollow metal float rests on the surface of the water, as level rises and falls, valve automatically closes and opens. This insures a constant supply of pure, clean drinking water-a vital factor in successful poultry and small stock raising. $\$ 1.00$ each, postpaid. 


\section{Increase Your Farm Profits by Preventing Costly Diseases with Dubay Seed Disinfectants Ceresan for Cotton}

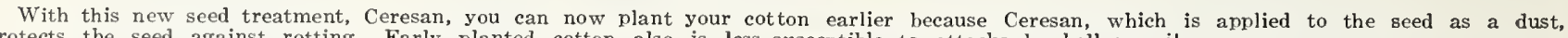
protects the seed against rotting. Early planted cotton also is less susceptible to attacks by boll weevil.

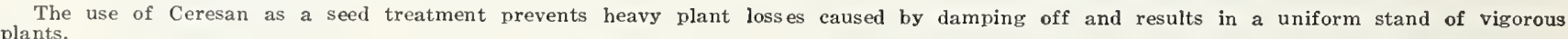
plants.

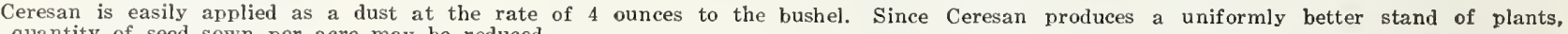
the quantity of seed sown per acre may be reduced.

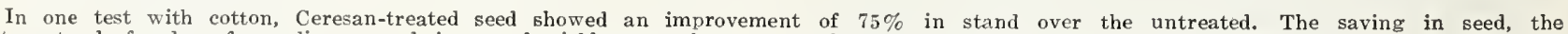
better stand, freedom from disease and increased yield more than repay the small cost of this remarkable treatment.

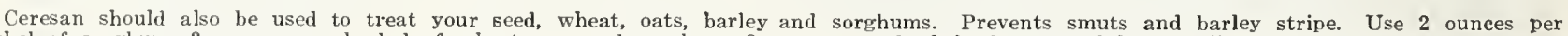

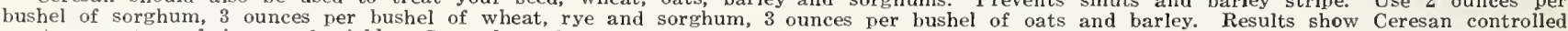

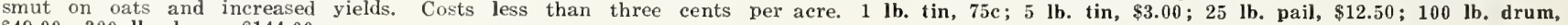
$\$ 49.00 ; 300$ lb. drum, $\$ 144.00$.

\section{Semesan Bel}

\section{For Seed Potatoes}

Instead of using chemicals for treating seed potatoes which require tedious soaking and which sometimes injure the seed piece, use the quick, easy, time-saving Semesan Bel treatment. Simply mix, dip, drain, dry and the potatoes are ready for planting. No hot water necessary. By controlling these diseases, germination is generally increased, stand improved and the resultant crop of potatoes is bigger and of better quality. Crop increases of from $10 \%$ to $15 \%$ are common. One pound treats 70 to 80 bushels of seed.

\begin{tabular}{|c|c|}
\hline $\begin{array}{l}\text {-oz. } \text { tin } \\
\text {-lb. tin }\end{array}$ & $\begin{array}{r}0.50 \\
\quad \$ \quad 1.75\end{array}$ \\
\hline 5-lb. & 8.00 \\
\hline 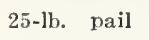 & 31.2 \\
\hline & \\
\hline & \\
\hline
\end{tabular}

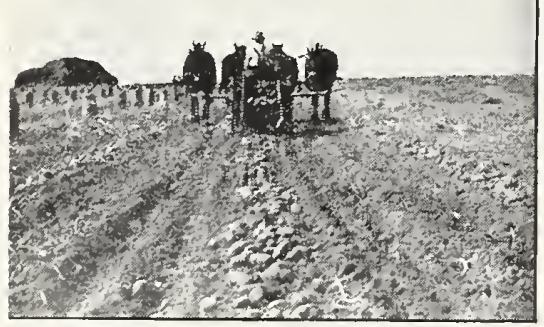

Harvesting a Record Crop of Semesan Bel Treated Potatoes.

\section{Semesan}

\section{For Vegetable and Flower Seeds}

Semesan should be applied in dust or liquid form to flower or vegetable seeds before planting. It is harmless to the seed, but deadly to any disease organisms that may be on the seed. One ounce treats 15 lbs. of seed. Effective in controlling damping-off, many seed-borne diseases and such devastating gladiolus diseases as hard rot and scab.

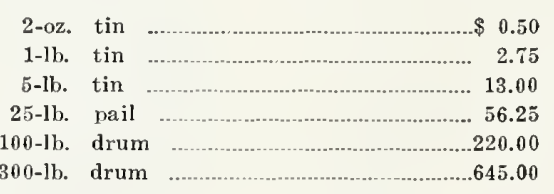

Robert Nicholson Seed Co.,

Granbury, Texas.

Dallas, Texas.

Gentlemen: Please send me your new catalog, also prices on Ceresan for treating seed oats.

I have always found your seeds the best that could be bought.

Yours truly,

J. WALLACE GILLIAM.

Robert Nicholson Seed Co.,

Monroe La.

Dallas, Texas.

Gentlemen: We placed an order with you last spring for 100 pounds of Ceresan to treat our cotton seed. We are well pleased with results and think it pays to use it.

(Signed) H. U. MILLSAP.

\section{Semesan Jr.}

\section{For Seed Corn}

Applied by the simple dusting method at the rate of 2 ounces to each bushel of seed field or sweet corn, Semesan Jr. offers the cheapest and most effective form of disease insurance. U. S. Government tests show Semesan Jr. increased the yield of disease-free seed as much as 1.9 bushels an acre.

Its use protects the seed from rotting in the ground and makes possible earlier planting which generally results in increased yields. Costs less than three cents per acre.

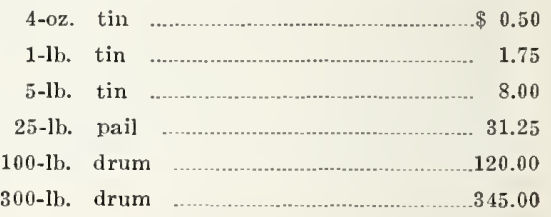

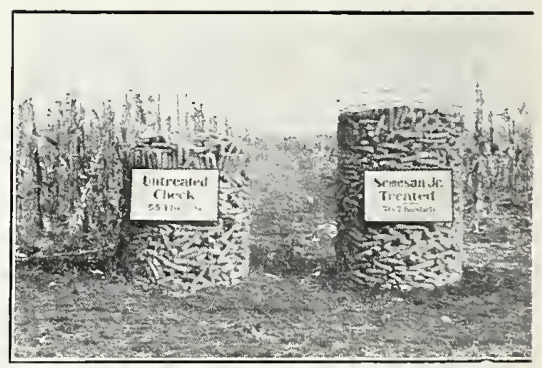

\section{Number of Plants to Are at Given Distances}

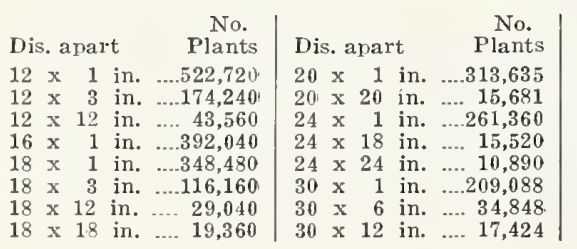

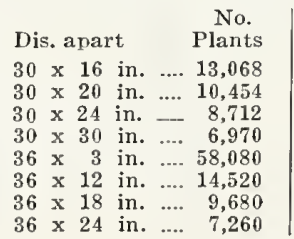

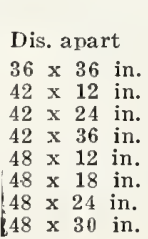

No.
Plants
4,840
12,446
6,223
4,148
10,890
7,790
5,445
4,356

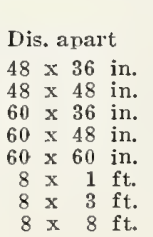

No.

Plants

3,630
2,723

2,723

2,178

1,743

5,445

1,815
680

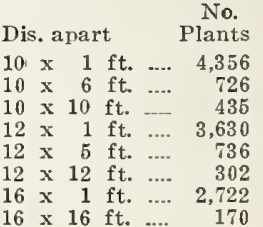




\section{Thompson's Seed Sowers}

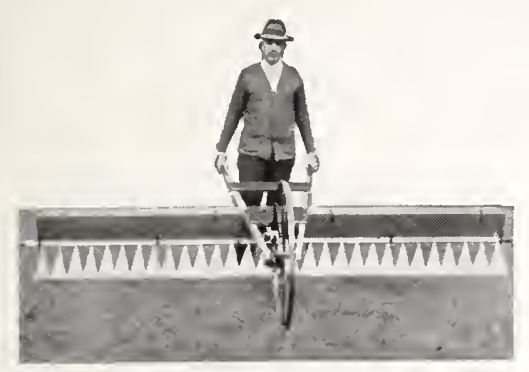

THOMPSON'S WHEELBARROW SEEDER

Used for broadeasting grass and other seeds on farms all over the world. Windy days or muddy ground do not delay seeding when the farmer owns a Thompson Grass Seeder.

The sced hopper is carried so low that the broadcasting is right close to the ground where the seed belongs and not in the air. Sowing by hand is wasteful.

The positive feed makes this the safe and sure way to get cnough seed sown evenly and accurately without wasting any-seed costs money.

The Seeder is instanly thrown wut of gear and the amount of seed sown is quickly bovcrned by changing the pin in the index plate. Prices f. o. b. Dallas.

No. 6. Single Hopper Seeder, $14 \mathrm{ft}$. Sows all seeds like Alfalfa, Clover, Bermuda Grass seed and oth॰r grasses of similar size. $\$ 15.00$.

No. 5. Double Hopper Seeder, $14 \mathrm{ft}$. Sows all seeds like Clover Bermuda Grass, Alfalfa and chaffy seeds like Red Top and clean lientucky Blue Grass. \$18.00.

No. 10. Universal Sceder, double hopper, $10 \mathrm{ft}$. length. Holds $11 / 2$ bushels. One seed range broadeasts all grass seeds from fine solid seeds to large chaffy seeds; the other seed range broadcasts all grains, soy beans and cowpeas. $\$ 19.00$

\section{Thompson Combination Broadcaster}

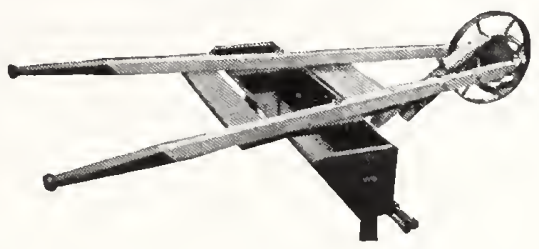

FOR SEED AND FERTILIZERS

For seeding and spreading fertilizers and all dry materials on lawns, parkways, golf tees, greens, flower and truck gardens

It broadcasts accurately and uniformly the desired quantity on small areas where othcrwise slow and uneven laborious hand work is required. The Thompson force ferd hroadcasting principle has been so arlapted to the 30 -inch hopper in this machine that it can be used equally as well for sceding and sureading

It broadcasts uniformly (without bunching) highly concentrated chemical fertil.zers and plant foods, lime, ground bone, pulverized sheep manure and wood ashes. It broadcasts equally as well all lawn and golf course seeds and mixtures. Quickly adjusted for any quantities desired.

Spreads as fast as a man will walk. The underslung hopper keeps the discharge closa to the ground where wind will not affect it. Its even distribution secures greatest ef ficiency from the material broadcast and by saving time, seed and fertilizer it quickly pays for itself,

No. 112-Combination Broadcaster. Shipping weight, $40 \mathrm{lbs}$., $\$ 13.50$ f. o. b. Dallas.
Hand Seed Sowers

CYCLONE BROADCAST SOWER

of simple and substantial construc tion. W ill seed, for sow ing broadeast. that any seeder will. \$2.15 each. not preaid. Ship lbs.
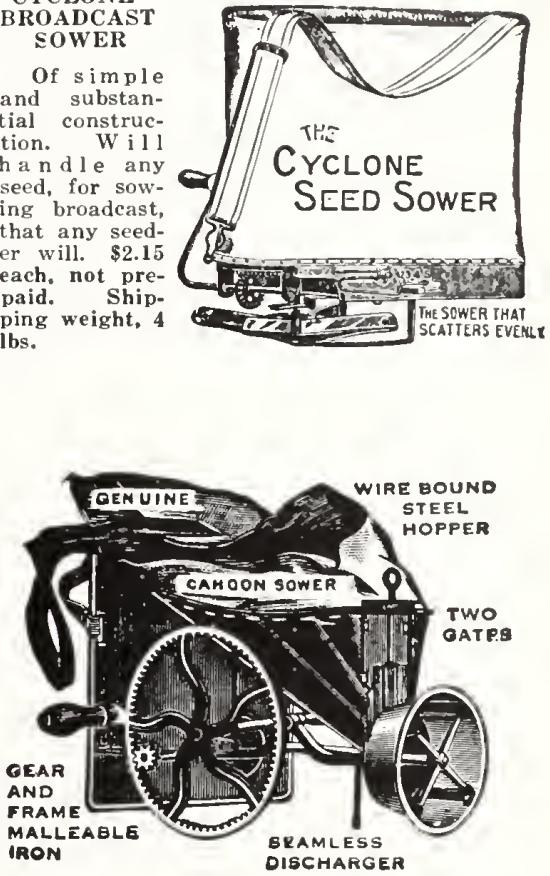

CAHOON BROADCAST SEED SOWER

One of the most valuable tools a farmer can own. Will sow most any kind of seed broadcast, giving a more even stand than sowing by hand; also saving in seed. Made durable, will last a lifetime. $\$ 5.00$, not prepaid. Shipping weight, $8 \mathrm{lbs}$.

\section{Nicholson's Field Seed Planting Schedule}

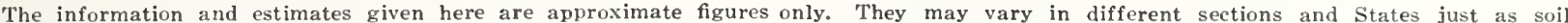
and climate vary. Often one farmer, to insure a full stand, will sow his seed more generously than his neighbor.

\begin{tabular}{|c|c|c|c|c|c|c|c|}
\hline Name & $\begin{array}{c}\text { Lbs. } \\
\text { per } \\
\text { Bushel }\end{array}$ & $\begin{array}{c}\text { Amounts } \\
\text { per } \\
\text { Acre }\end{array}$ & Time of Planting & Name & $\mid \begin{array}{c}\text { Lbs. } \\
\text { per } \\
\text { Bushel }\end{array}$ & $\begin{array}{c}\text { Amounts } \\
\text { per } \\
\text { Acre }\end{array}$ & Time of Planting \\
\hline 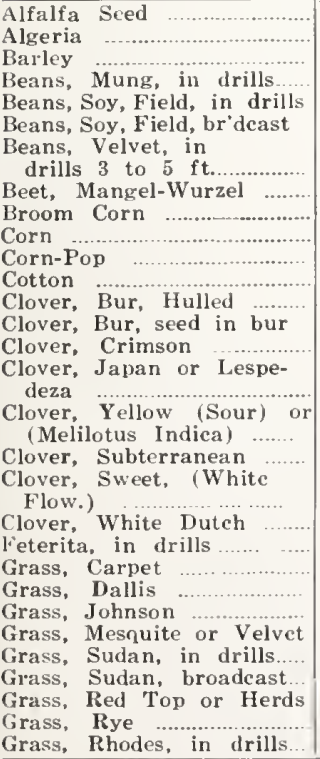 & $\begin{array}{l}60 \\
50 \\
48 \\
60 \\
60 \\
60\end{array}$ & 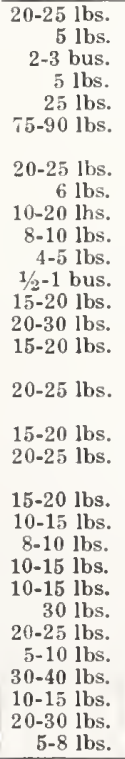 & $\begin{array}{l}\text { Sept.-Nov., Feb.-All. } \\
\text { March-June } \\
\text { Sept.-Oct., Feb. } \\
\text { April-June } \\
\text { April-July } \\
\text { April-July } \\
\text { March-June } \\
\text { 15th Mar. to 15th June } \\
\text { Feb.-June } \\
\text { Feb.-June } \\
\text { Feb.-May } \\
\text { Feb.-June } \\
\text { 15th Aug.-Oct. } \\
\text { 15th Aug.-Oct. } \\
\text { Sept.-Oct. } \\
\text { Mar.-April, Sept.-Nov. } \\
\text { Sept.-Feb. } \\
\text { Sept.-Oct. } \\
\text { Sept.-Oct., Feb.-Apr. } \\
\text { Sept.-Oct., Feb.-Apr. } \\
\text { March-June } \\
\text { Sept.-Oct., Feb.-Apr. } \\
\text { Sept.-Nov., Feb.-Apr. } \\
\text { March-May } \\
\text { Sept.-Oct., Feb.-Apr. } \\
\text { March-June } \\
\text { March-June } \\
\text { Sept.-Oct., Feb.-Mar. } \\
\text { Sept.-Oct. } \\
\text { March-April }\end{array}$ & 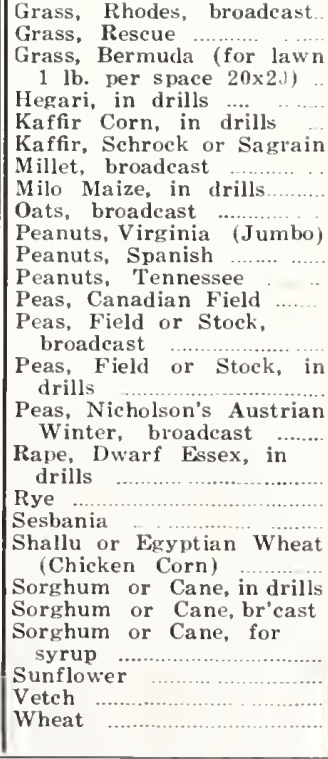 & $\begin{array}{l}50 \\
50 \\
50 \\
50 \\
50 \\
32 \\
22 \\
30 \\
22 \\
60 \\
60 \\
60 \\
60\end{array}$ & \begin{tabular}{|r}
$10-15 \mathrm{lbs}$. \\
$15-25 \mathrm{lbs}$. \\
$8-10 \mathrm{lbs}$. \\
$8-10 \mathrm{lbs}$. \\
$8-10 \mathrm{lbs}$. \\
$8-10 \mathrm{lbs}$. \\
$20-25 \mathrm{lhs}$. \\
$8-10 \mathrm{lbs}$. \\
$21 / 2-3 \mathrm{bus}$. \\
$1-11 / 2 \mathrm{bus}$. \\
$30-40 \mathrm{lbs}$. \\
$1-11 / 2 \mathrm{bus}$. \\
$35-75 \mathrm{lbs}$. \\
\\
$1-11 / 2 \mathrm{bus}$. \\
$8-12 \mathrm{lbs}$. \\
\\
$60-65 \mathrm{lbs}$. \\
$5-8 \mathrm{lbs}$. \\
$11 / 11 / 9 \mathrm{lbs}$. \\
$30-35 \mathrm{lbs}$. \\
$8-10 \mathrm{lbs}$. \\
$5-10 \mathrm{lbs}$. \\
$100-150 \mathrm{lbs}$. \\
$5-10 \mathrm{lbs}$. \\
$5-10 \mathrm{lbs}$. \\
$40-50 \mathrm{lbs}$. \\
$75-90 \mathrm{lbs}$.
\end{tabular} & $\begin{array}{l}\text { March-April } \\
\text { Sept.-Oct. } \\
\text { March-May } \\
\text { March-July } \\
\text { March-June } \\
\text { March-June } \\
\text { April-June } \\
\text { March-June } \\
\text { Sept.-Oct., Feb. } \\
\text { March-June } \\
\text { March-June } \\
\text { March-June } \\
\text { Sept.-Nov. } \\
\text { March-Nov. } \\
\text { March-Nov. } \\
\text { Sept.-Nov. } \\
\text { Sept.-Oct.. Feb.-April } \\
\text { Sept.-Oct. } \\
\text { March-June } \\
\text { March-June } \\
\text { Feb.-July } \\
\text { Feb.-July } \\
\text { Feb.-June } \\
\text { March-May } \\
\text { Aug.-Nov. } \\
\text { Sept.-Nov. }\end{array}$ \\
\hline
\end{tabular}


